\title{
Next Generation Geothermal Power Plants
}

\section{EPRI RP 3657-01}

Draft Final Report, December 1994

\section{Prepared by}

The Ben Holt Co.

201 S. Lake Avenue

Pasadena, CA 91101

Principal Investigators:

John Brugman

Mai Hattar

Kenneth Nichols

Yuri Esaki

\section{Prepared for}

Electric Power Research Institute

3412 Hillview Avenue

Palo Alto, California 94304

EPRI Project Manager

Dr. Evan Hughes 


\section{DISCLAIMER OF WARRANTIES AND LIMITATION OF LIABILITIES}

THIS REPORT WAS PREPARED BY THE ORGANIZATION(S) NAMED BELOW AS AN ACCOUNT OF WORK SPONSORED OR COSPONSORED BY THE ELECTRIC POWER RESEARCH INSTTUTE, INC. (EPRD. NEITHER EPRI, ANY MEMBER OF EPRI, ANY COSPONSOR, THE ORGANIZATION(S) NAMED BELOW, NOR ANY PERSON ACTING ON BEHALF OF ANY OF THEM:

(A) MAKES ANY WARRANTY OR REPRESENTAITON WHATSOEVER, EXPRESSED OR IMPLED, (I) WITH RESPECT TO THE USE OF ANY NFORMATION, APPARATUS, METHOO, PROCESS OR SIMLAR ITEM DISCLOSED WN THIS REPOAT, INCLLDING MERCHANTABILTY AND FTNESS FOR A PARTICULAR PURPOSE OR (II) THAT SUCH USE DOES NOT INFRINGE ON OR NTERFERE WITH PRNATELY OWNED RIGHTS, NCLUDING ANY PARTY'S INTELLCTUAL PROPERY, OR (III) THAT THIS REPORT IS SUITABLE TO ANY PARTICULAR USER'S CIRCUMSTANCE, OR

(B) ASSUMES ANY RESPONSIBILTY FOR ANY DAMAGES OR OTHER LIABILTY WHATSOEVER (NCLUDING ANY CONSEQUENTIAL DAMAGES, EVEN IF EPRI OR ANY EPRI REPRESENTATNE HAS BEEN ADVISED OF THE POSSIBIUTY OF SUCH DAMAGES RESULTING FROM YOUR SELECTION OR USE OF THIS REPORT OR ANY NFORMATION, APPARATUS, METHOD, PROCESS OR SIMILAR ITEM DISCLOSED IN THIS REPORT.

ORGANIZATION(S) THAT PREPARED THIS REPORT:

THE BEN HOLT $C O$. 


\section{DISCLAIMER}

Portions of this document may be illegible in electronic image products. Images are produced from the best available original document. 


\section{CONTENTS}

Section

Page

1 Executive Summary.........................................................................1-1

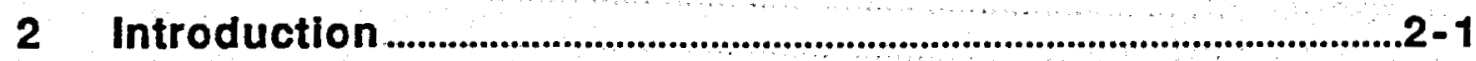

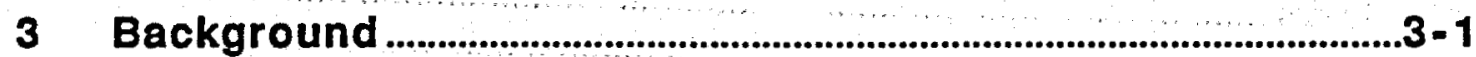

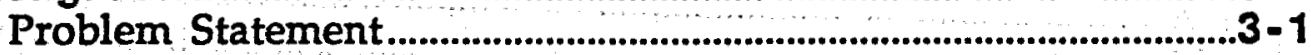

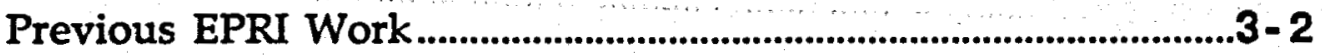

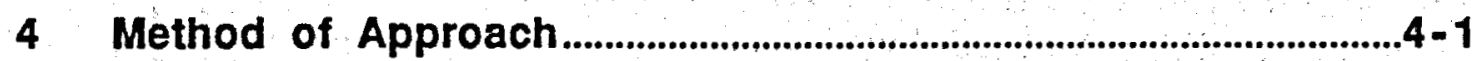

Introduction

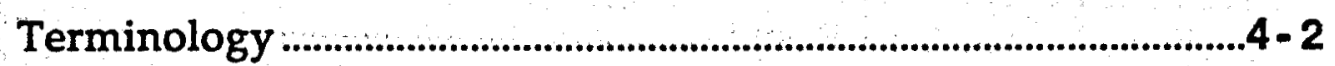

General Methodology ........................................................................4-3

Assumptions..................................................................................................4-5

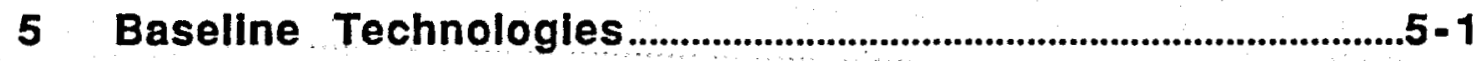

Air-cooled Commercial Binary ..............................................................

Water-cooled Commercial Binary ...........................................................5-10

Commercial Dual Flash .................................................................5-17

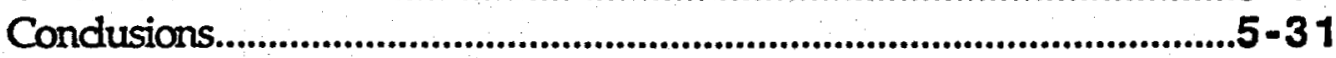

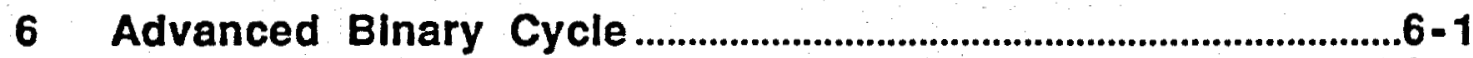

Mixed Fluid Binary: Hydrocarbon Mixtures.....................................6-1

Synchronous Speed Generator ..............................................................6-20

Advanced Binary/Metastable Expansion .............................................6-22

Binary Cycle: Hot Dry Rocks......................................................................6-33

7 Advanced Flash Cycles....................................................................

Dual Flash/Rotary Separator Turbine...................................................7-1

Dual Flash/Steam Reheater ...............................................................7-9

Subatmospheric Flash....................................................................7-14

Dual Flash/Hot Water Turbine .................................................................7-19 


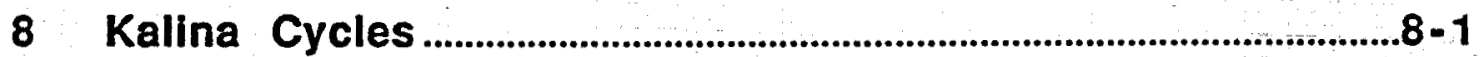

Kalina Cycle System 11 ...................................................................... 8-1

Kalina Cycle System 13 ................................................................................8 8-18

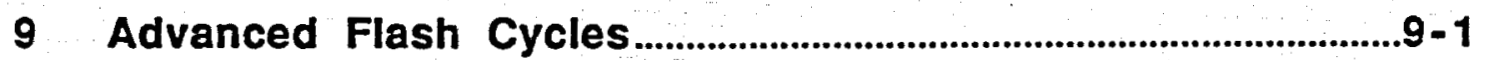

Dual Flash/Binary Bottoming Cycle...................................................9-1

Dual Flash/Back Pressure Turbine Binary .........................................9-7

Dual Flash/Gas Turbine Hybrid ............................................................9-14

i. Binary/Gas Turbine Hybrid.................................................................9-21

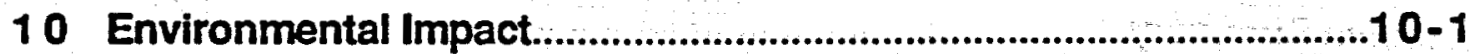

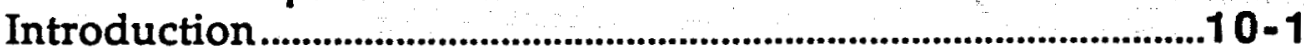

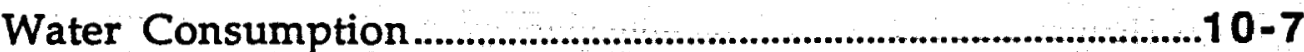

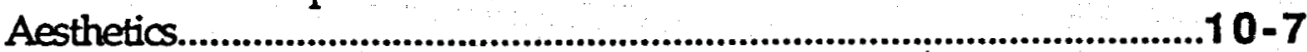

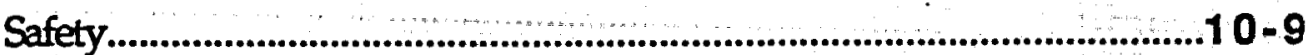

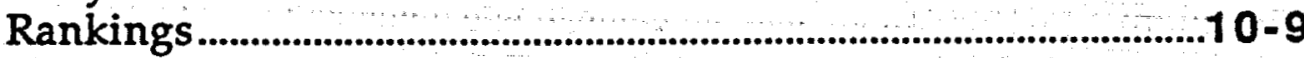

11 Next Generation Geothermal Power Plant Tech.....................11-1

Concept Ranking Methodology ...................................................11-1

Leveliżed Busbar Cost Methodology ............................................11-2

Levelized Busbar Cost Results .......................................................11-5

Concept Ranking Results ..............................................................11-9

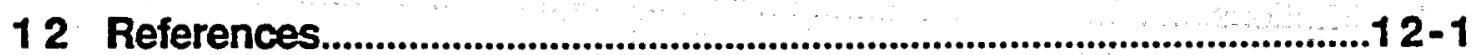

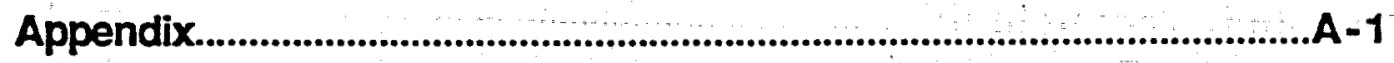




\section{LIST OF FIGURES}

Figures

Pàge

5-1 Air-cooled Commercial Binary Cycle: Process Flow Diagram................5-4

5-2 Air Cooled Commercial Binary: Specific Output Curves..........................5-5

5-3 Air-cooled Commercial Binary Cycle: Specific Output v Resource.......5-6

5-4 Air-cooled Com'l. Binary Cycle: Specific Capital Cost v Resource........5-9

5-5 Water Cooled Commercial Binary Cycle: Process Flow Diagram.........5-12

5-6 Specific Capital Cost v. Condenser Pinch: Vale, Oregon............................5-13

5-7 Water Cooled Binary: Specific Output v. Turbine Inlet Pressure..........5-14

5-8 Water Cooled Binary: Specific Cost v. Turbine Inlet Pressure ...............5-15

5-9 Commercial Dual Flash Cycle: Process Flow Diagram...............................5-22

5-10 Condenser Approach Optimization .................................................................5-23

5-11 Comparison of Vacuum Systems .................................................................5-24

5-12 Cooling Water Circulation Optimization.....................................................5-25

5-13 Commercial Dual Flash Cycle: Specific Output v Resource.....................5-26

5-14 Commercial Dual Flash Cycle: Specific Capital Cost v Resource...........5-27

5-15 Baseline Technologies - Specific Capital Cost v Resource.......................5-32

5-16 Baseline Technologies - Specific Output $v$ Resource..................................5-33

6-1 Mixed Fluids Specific Output Curves (SV)..................................................6-10

6-2 Mixed Fluids Specific Capital Cost Curves Curves (SV)..........................6-11

6-3 Specific Capital Cost v. Cold End Pinch.......................................................6-12

6-4 Mixed Fluids Specific Output Curves (VO) ..................................................6-13

6-5 Mixed Fluids Specific Capital Cost Curves Curves (VO) ..........................6-14

6-6 Mixed Fluids Specific Output Curves (RR).................................................6-15

6-7 Mixed Fluids Specific Capital Cost Curves Curves (RR)..........................6-16

6-8 Mixed Fluids: Optimizing Condensing Temperatures (THS) ...............6-17

6-9 Mixed Fluids Specific Output Curves (THS) ..............................................6-18

6-10 Mixed Fluids Specific Capital Cost Curves Curves (THS) .......................6-19

6-11 Metastable Expansion for Hypothetical Cycle.............................................6-27

6-12 Comparison of NIST-12 and Starling Equation of State ........................6-28

6-13 Ratio of Metastable Expansion and Commercial Binary Costs..............6-29

6-14 Metastable Expansion Binary Specific Output Curves (VO) ...................6-30

6-15 Metastable Expansion Binary Specific Output Curves (SV).....................6-31

6-16 Metastable Expansion Binary Specific Output Curves (RR)....................6-32

6-17 Hot Dry Rocks Surface System Design $\quad$ 6-34 
9-1 Summary of Cases.......................................................................................6-6

9-2 Dual Flash/Back Pressure Turbine Binary - Major Equip. Costs...............9-13

9-3 Dual Flash/Gas Turbine Hybrid - Major Equipment Costs.........................9-20

9-4 Specific Output, $\mathrm{kWh} / 1000 \mathrm{lb}$ Brine...............................................................9-28

9-5 Exhaust Gas Heat Input.......................................................................................9-28

9-6 Specific Capital Costs.............................................................................................9-28

10-1 Open Cycle NCG Emissions Tables.................................................................10-5

10-2 Gas Turbine Exhaust.............................................................................10-8

10-3 Environmental Impact Rankings..................................................................10-10

11-1 Levelized Busbar Cost of Power Generation Assumptions .....................11-3

11-2 Levelized Busbar Cost of Power Plant Assumptions..................................11-4

11-3 Resource Development Costs..................................................................11-5

11-4 Levelized Revenue Requirement.................................................................11-7

11-5 Secondary Ranking Criteria .................................................................11-8

11-6 Concept Ranking ........................................................................11-10 


\section{EXECUTIVE SUMMARY}

A number of current and prospective power plant concepts were investigated to evaluate their potential to serve as the basis of the next generation geothermal power plant (NGGPP). The NGGPP has been envisaged as a power plant that would be more cost-competitive (than current geothermal power plants) with fossil fuel power plants, would efficiently use resources and mitigate the risk of reservoir underperformance, and minimize or eliminate emission of pollutants and consumption of surface and ground water.

Power plant concepts were analyzed using resource characteristics for resources at ten different geothermal sites located in the western United States. Concepts were developed into viable power plant processes, capital cost was estimated and levelized busbar costs determined. Thus, the study results are rooted in reality and should be considered as useful indicators of the commercial viability of the various power plants concepts that were investigated.

Broadly, the different power plant concepts that were analyzed in this study fall into the following categories: baseline binary and flash plants, advanced binary plants, advanced flash plants, Kalina cycles, flash/binary hybrid plants, and fossil/geothermal hybrid plants. Commercial binary plants were evaluated using commercial isobutane as a working fluid; both air-cooling and water-cooling were considered. Advanced binary concepts included cycles using synchronous turbine-generators, cycles with metastable expansion, and binary cycles utilizing mixtures as working fluids.

Dual flash steam plants were used as the model for the baseline flash cycle. The following advanced flash concepts were examined: dual flash with rotary separator turbine, dual flash with steam reheater, dual flash with hot water turbine, and subatmospheric flash. Both dual flash and binary cycles were combined with other cycles to develop a number of hybrid cycles: dual flash binary bottoming cycle, dual flash - backpressure turbine binary cycle, dual flash - gas turbine cycle, and binary - gas turbine cycle. 
Two Kalina cycles, system 11 and system 13, were examined. These cycles use ammonia-water mixtures as working fluids. Kalina cycles are also characterized by a significant degree of heat recuperation.

Results of this study indicate that dual flash type plants are preferred at resources with temperatures above $400^{\circ} \mathrm{F}$. Closed loop (binary or Kalina type) plants are preferred at resources with temperatures below $400^{\circ} \mathrm{F}$. A rotary separator turbine upstream of a dual flash plant can be beneficial at Salton Sea, the hottest resource, or at high temperature resources where there is a significant variance in wellhead pressures from well to well. For the closed loop cycles, a hydrocarbon working fluid is preferred for $375^{\circ} \mathrm{F}$ and $330^{\circ} \mathrm{F}$ resources and an $\mathrm{NH}_{3} / \mathrm{H}_{2} \mathrm{O}$ working fluid at the two lowest temperature resources. If natural gas prices remain low, a combustion turbine/binary hybrid is an economic option for the lowest temperature sites.

It is unlikely that a next generation geothermal power plant concept will reduce the cost of power generation by much more than $10 \%$. Colder resources will benefit more from the development of a next generation geothermal power plant than will hotter resources.

All values presented in this study for plant cost and for busbar cost of power are relative numbers intended to allow an objective and meaningful comparison of technologies. The goal of this study is to assess various technologies on an equal basis and, secondarily, to give an approximate idea of the current costs of the technologies at actual resource areas. Absolute costs at a given site will be determined by the specifics of a given project. 


\section{2}

\section{INTRODUCTION}

\section{Project Goal}

The goal of this project is to develop concepts for the next generation geothermal power plant(s) (NGGPP). This plant, compared to existing plants, will generate power for a lower levelized cost and will be more competitive with fossil fuel fired power plants. The NGGPP will utilize geothermal resources efficiently and will be equipped with contingencies to mitigate the risk of reservoir underperformance. The NGGPP design will attempt to minimize emission of pollutants and consumption of surface water and/or geothermal fluids for cooling service.

\section{Project Déscription}

This project was funded by a consortium of governmental agencies and Western utilities. The Electric Power Research Institute (EPRI) acted as manager on behalf of this consortium. The Ben Holt Co. (henceforth Holt) was the prime contractor for the project, and Fuji Electric Company and Barber-Nichols were sub-contractors on the project. John Brugman and Mai Hattar of Holt, Kenneth Nichols of Barber-Nichols Inc. and Yuri Esaki of Fuji Electric Company, Ltd. were the principal investigators.

As per the RFP, the project was envisaged as Phase I of a planned multi-phase project to develop the NGGPP. This phase includes studies to develop NGGPP concepts, to obtain performance estimates and comparisons of these concepts, to prepare preliminary concept capital and power generation cost estimates, and to rank NGGPP concepts for each of several geothermal sites.

Geothermal sites were chosen such that the NGGPP concepts would be evaluated using resources with "real world" characteristics, and the effect of noncondensable gas content, solids composition, resource temperature, well costs, ambient conditions etc. on each concept's performance would be accounted for. The chosen resources are real not hypothetical.

Furthermore, the investigators are engaged in the design and construction of geothermal power plants, and in the production of geothermal power plant equipment. Therefore, the project was approached as an effort to compare prospective NGGPP technologies on a basis consistent with the requirements of commercially viable projects. 
The project was funded in November, 1993 and Holt commenced work in December 1993. A steering committee comprised of representatives of the Department of Energy, Southern California Edison, Bonneville Power Administration, and EPRI directed the project. The steering committee held two review meetings to evaluate the progress of the project; the first on May 25, 1994, and the second on November 2 and 3, 1994. The second review meeting was also attended by representatives from Exergy, Inc. and Biphase Energy for the sessions on Kalina cycles and rotary separator turbine, respectively, and by a representative from Fuji Electric Company. Phase I of the project was completed in December, 1994. 


\section{3}

\section{BACKGROUND}

\section{Problem Statement}

Geothermal energy is an indigenous, sustainable and environmentally. benign energy source. Geothermal power plants emit minimal combustion products into the atmosphere compared to fossil fuels. However, although large geothermal resources exist, currently geothermal power is not cost competitive with power generated using natural gas. Furthermore, long-term risk may be associated with geothermal power since some geothermal reservoirs have under-performed in that geothermal fluid temperatures or flow rates have declined over time. Additionally, many of the high temperature, easily accessible resources have been developed, and now primarily lower temperature resources must be considered.

In an effort to alleviate these problems, this study seeks to develop concepts that may form the basis for developing the next generation geothermal power plant(s) (NGGPP). The NGGPP, as defined, "will have higher power conversion efficiencies, better geothermal resource utilization, and lower power generation costs than current proven geothermal power generation technologies" (EPRI RFP3657-01, 1993). As envisaged, the NGGPP performance will be relatively unaffected by risks associated with geothermal reservoir under-performance. Moreover, the NGGPP is perceived to have a minimal impact on the environment and resources; the NGGPP will minimize cooling water requirements and maximize injection of geothermal fluids to enhance resource utilization, and it will minimize or eliminate emission of greenhouse gases and acid gases.

The NGGPP design will be flexible in that it can be adapted to utilize liquid dominated or hot dry rock geothermal resources. Moreover, in view of the fact that a number of resources are low temperature resources, the ideal NGGPP should be able to efficiently generate-power from resources below $300^{\circ} \mathrm{F}$. The NGGPP design should be modullar with-improved operätional and planning flexibilities compared to existing geothermal power plants so as to comply with utility needs. 


\section{Previous EPRI Work}

At EPRI's "Third Annual Geothermal Conference and Workshop", the workshop topic was "Looking Ahead to the Next Generation of Geothermal Power Systems". The workshop focused on three areas of development: (1) desired characteristics of future systems, (2) emerging technology and (3) research and development needs. Several promising technologies that could impact future geothermal power plants were identified by workshop participants. The list of technologies included well stimulation techniques, downwell pumps, advanced flash systems, advanced binary systems, and twophase expanders. Details of the workshop can be found in the conference proceedings published in 1979 (EPRI 1979).

From 1979 to 1983 EPRI funded the "Assessment of Advanced Geothermal Energy Conversion Concepts" program under EPRI RP 1673-1. As a part of this program a number of advanced geothermal concepts were investigated, including advanced flash steam cycles, advanced binary cycles, hybrid cycles (fossil/geothermal and solar/geothermal), and total flow devices (rotary separator turbine, helical expander, bladeless turbine, LLL impulse turbine, LLL reaction turbine, Elliot turbine and Horst expander). Partial results of this program were presented at the "Fifth Annual Geothermal Conference and Workshop" (Holt et al, 1981).

Under EPRI contract RP1673-4, The Ben Holt Co. evaluated methane and hot water hybrid cycles. Hybrid cycles were calculated to produce as much as $30 \%$ more electricity than if methane was used separately in a fossil fuel power plant and hot water in a binary cycle plant. This $30 \%$ improvement is based on a cycle in which enough methane is combusted so that exhaust heat provides all necessary energy to vaporize the working fluid.

Under EPRI contract RP1671-5 and DOE contract DE-AC07-85ID12578, The Ben Holt $\mathrm{Co}$. designed, built and successfully operated a hybrid cycle power plant on the Pleasant Bayou geopressured resource in Texas. Since geopressured resource contains both methane and geothermal brine, a hybrid cycle was employed to fully utilize the resource. In the hybrid cycle at Pleasant Bayou, gas was burned in engines to generate electricity directly. Exhaust heat from the engines was then combined with heat from the brine to generate additional electricity in a binary cycle.

The Ben Holt Co. performed work under EPRI project, RP1671-07, to extend the application of hybrid plants to geothermal resources which are not geopressured and to include biomass fuels as an alternative to natural gas. 
During the design phase, there were many mechanical design concerns about the exhaust gas-to-isobutane exchanger. These concerns were due to high temperature operation and to the large temperature difference between the inlet exhaust gas and the outlet isobutane temperature. A unique exchanger ( See Figure 3-1) was designed by The Ben Holt Co. which solved the thermal stress problem. This exchanger is a horizontal reboiler type exchanger with a U-tube bundle. U-tubes are used because their flexibility allows for differential growth of the tubes. The problem of differential expansion across the tubesheet and channel is solved by having a two-piece channel. Separate inlet and outlet channels are bolted onto the tubesheet without being connected in any way. The inlet channel can therefore grow more than the outlet channel without putting too much stress on the connections to the tubesheet. This design is currently being patented by EPRI.

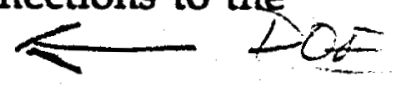

This exchanger was built of 304 stainless steel nd showed no sign of corrosion. Also, there was no sign of year between the tubes and the tubesheet support due to vibration. However, carbon deposits from the gas engine exhaust caused fouling of the heat exchange surface thus degrading performance. This fouling may have been caused by the use of impure wellhead gas rather than pipeline natural gas. A gas turbine has lower particulate-mission than a gas engine, so fouling would be lower with a gas turbine.

The Ben Holt Co. performed work under EPRI project, RP1671-07, to extend the application of hybrid plants to geothermal resources which are not geopressured and to include biomass fuels as an alternative to natural gas. 


\section{4}

\section{METHOD OF APPROACH}

\section{Introduction}

The development of the next generation geothermal power plant entails choosing a physically realizable and economically feasible technology from a host of geothermal power plant concepts: advanced binary and flash plants, Kalina cycles with ammonia-water mixtures as working fluids, advanced flash/binary hybrid plants, and fossil/geothermal hybrid plants.

In consultation with the steering committee seventeen specific geothermal power plant concepts were identified for evaluation in this study. These are listed below. It is worth noting that the first three concepts represent proven technology and provide a baseline for evaluating other technologies. The remaining concepts are in various stages of development and will require demonstration on a significant scale to be classified as "commercial".

\section{Baseline Technologies}

- Commercial air-cooled binary

- Commercial water-cooled binary

- Commercial dual flash

Advanced Binary Cycles

- Mixed fluids binary: hydrocarbon mixtures

- Mixed fluids binary: aqua-ammonia mixtures

- Synchronous speed turbine

- Metastable expansion

\section{Advanced Flash Cycles}

- Dual flash with rotary separator turbine

- Dual flash with steam reheater

- Sub-atmospheric flash

- Hot water turbine 
Kalina Cycles

- Kalina Cycle System 11

- Kalina Cycle System 13

\section{Hybrid Cycles}

- Dual flash/binary bottoming cycle hybrid

- Dual flash backpressure turbine/binary hybrid

- Dual flash/gas turbine hybrid

- Binary cycle/gas turbine hybrid

As noted in the introduction, these geothermal power plant concepts were applied to existing, known geothermal sites in an effort to ground the results of this study in real-world applications. In addition, geothermal sites were chosen so that the NGGPP technologies would be applicable to resources with widely varying characteristics. Detailed resource characteristics for the selected sites are listed in Table $4-1$ (provided by EPRI) which shows that the selected resources cover a broad range of temperatures, noncondersable gas composition, and solids content. The following resources were-used in this study:

- $\quad$ Glass Mountain, California $\left(510^{\circ} \mathrm{F}\right)$

- $\quad$ Salton Sea, California $\left(570^{\circ} \mathrm{F}\right)$

- $\quad$ Surprise Valley, California $\left(375^{\circ} \mathrm{F}\right)$

- Thermo Hot Springs, Utah $\left(265^{\circ} \mathrm{F}\right)$

- Vale, Oregon $\left(330^{\circ} \mathrm{F}\right)$

- Clear Lake Geysers, California $\left(375^{\circ} \mathrm{F}\right)$

- Coso Hot Springs, California $\left(525^{\circ} \mathrm{F}\right)$

- Desert Peak, Nevada (425 $\left.{ }^{\circ} \mathrm{F}\right)$

- Dixie Valley, Nevada $\left(450^{\circ} \mathrm{F}\right)$

- $\quad$ Raft River, Idaho (300 $\left.{ }^{\circ} \mathrm{F}\right)$

\section{Terminology}

Throughout this report the results of the evaluation of NGGPP technologies are presented in terms of specific output and specific capital cost. Specific output provides an index for the thermodynamic performance of power plant cycles and is sometimes referred to as brine utilization rate. It is defined as:

Specific output $=$ Net power $(\mathrm{kW}) /$ Brine mass flow rate $(1000 \mathrm{lb} / \mathrm{hr})$ 
Specific capital cost is an index used for assessing the economic performance of power plant technologies and is defined as:

Specific capital cost $=$ Facility capital cost $(\$) /$ Net power $(\mathrm{kW})$

Facility capital cost in equation 4-2 is the capital expense required to develop the wellfield and build the power plant but does not include the cost of land, interest on capital and owner's project expenses. All costs in this study were calculated in 1994 dollars.

\section{General Methodology}

In order to accomplish the study objectives, cyele-concepts were optimized for each applicable site using minimum specific capital cost as the figure of merit. Cycle optimization to minimize specific capital cost was accomplished in two stages: (1) performance analysis and (2) economic analysis. In the performance analysis stage a number of process cases were simulated for a given cycle and resource to obtain a set of cases that could be expected to contain the economic optimum cycle. The thermodynamic optimum for the subject cycle was determined at this time. Identification of the optimum cycle was completed in the economic analysis stage wherein cost evaluation of the cases generated during performance analysis was performed. A discussion of performance and economic analysis is presented below.

Rankings for NGGPP concepts were developed using levelized busbar costs. The methodology for calculating levelized busbar costs is presented along with NGGPP concept rankings in Chapter 11.

\section{Performance Analysis: Concept Development and Cycle Analyses}

Performance analysis of each concept involved developing the cycle process design consisting of a process flow diagram and process model. The process model was used to simulate cycle performance by varying process variables, and several performance cases were developed corresponding to different sets of process variables for each cycle. Process variables were chosen to obtain the cycle specific output over a range of important process constraints such as pinch points, temperature approaches, etc. The range of process constraints was chosen based on Holt's experience in designing and building commercial geothermal power plants.

With the exception of the Kalina cycles, the NGGPP concepts examined in this study involved variations of commercial binary and/or commercial flash cycles. Holt has proprietary mathematical models for designing both types of cycles, and these Holt models were used for the process design of most cycles. Kalina cycles were simulated using HYSIM, a commercial process simulator. Details of the Holt models for the commercial binary and commercial flash cycles are presented in the sections on the air-cooled commercial binary and 
commercial dual flash cycles, respectively. Performance modeling details for the Kalina cycles are presented in the section on Kalina cycle system 11.

\section{Economic Analysis: NGGPP Capital Cost Evaluation}

For the purpose of economic optimization, the optimum plant design was defined as the plant design corresponding to minimum specific capital cost. In order to compare all concepts on an even basis, a power plant design with a nominal capacity of $50 \mathrm{MW}$ (net) was used as the basis for estimating capital costs for all concepts. With this basis, the objective of minimizing specific capital cost $(\$ / \mathrm{kW})$ was reduced to the objective of minimizing facility capital cost and throughout this report minimum specific capital cost has been used as the figure of merit for identifying the economic optimum.

Facility capital cost was calculated as the sum of power plant cost and wellfield cost. Power plant costs were estimated from major equipment costs using the factored method: major equipment costs were summed and multiplied by a plant cost multiplier to account for engineering and installation costs. The multipliers used in this study are based on Holt experience in designing and building both binary and flash geothermal power plants in the recent past, and are listed in Table 4-5. Wellfield costs were calculated using production and injection well costs provided by EPRI. Production and injection well costs for the various geothermal sites are listed in Table 4-1. Using facility capital costs, specific capital costs were obtained for the set of cycle designs developed in the performance analysis stage, and the cycle design corresponding to minimum specific capital cost was chosen as the economically optimum cycle design.

Details of cost estimation methods are presented in Appendix A; some general comments follow. Major equipment costs were obtained from Holt's extensive database supplemented where necessary by current vendor quotations. For similar pieces of equipment, costs from the same vendor were used for evaluating all competing technologies. For example, turbine costs for all evaluated NGGPP concepts are based on turbine cost data from Fuji Electric Company, a co-investigator in this study. The underlying philosophy has been to evaluate competing technologies within the same frame of reference. It should be pointed out that the choice of vendors was based on the experience and reputation of vendors specially with reference to geothermal power plant installations in the United States. Fuji Electric Company's turbines, for example, account for approximately $40 \%$ of the geothermal power plant capacity in the United States.

Meteorology data necessary to estimate the size and cost of heat rejection equipment (condensers, cooling towers) were obtained using the Department of Navy publication, "Facility Design and Planning - Engineering Weather Data". Using the criteria of proximity, climate and altitude this publication 
was used to obtain wet bulb and dry bulb temperatures for Navy sites that closely mimic the selected geothermal sites. The average dry bulb and wet bulb temperatures thus obtained, along with site altitude are listed in Table 4-2 for all the geothermal sites considered in this study. This study used annual average weather conditions assuming a constant (not seasonally differentiated) cost of power.

\section{Environmental Impact}

The environmental impact of each NGGPP concept has been assessed in this study. The main areas of concentration are surface and ground water use and pollutant emissions for each optimized cycle for each resource.

The presence of noncondensable gases in geothermal brine poses the primary emissions concern for flash plants. Consequently, a liquid redox sulfur plant is included in the design of flash plants for $\mathrm{H}_{2} \mathrm{~S}$ abatement, and it is assumed that carbon dioxide, a greenhouse gas, can be emitted to the atmosphere.

\section{Next Generation Geothermal Power Plant Concepts Ranking}

Calculation of busbar costs and assessment of environmental impact of each candidate technology forms the basis for ranking NGGPP concepts. This study ranks concepts based on busbar costs. Second level considerations are used to discriminate between technologies only in cases where two or more concepts have almost equal busbar costs. The following second level considerations are used to "break ties":

- Technology risk

- Environmental considerations

- Water consumption

\section{Assumptions}

This section presents the assumptions that are common to all NGGPP concepts evaluated in this study. As mentioned in the previous section, the characteristics of each site and meteorological data for each resource are presented in Table 4-1 and 4-2, respectively. In addition, Table 4-3 provides the maximum wellhead pressure for self-flowing wells, and Table 4-4 provides the composition of non-condensable gases in the brine for each resource. These tables are used to obtain the following data for each site as required for each concept:

- Average dry/wet bulb temperatures

- Composition of noncondensable gases in the geothermal brine

- $\quad$ Site altitude 
- Geothermal fluid temperature

- Minimum injection temperature

- Average well flowrates

- Average well cost

- Concentration of total dissolved solids

- Probability of a dry hole

- Maximum flash pressure

The following general assumptions have been used as applicable in the development of performance and cost models for the various NGGPP concepts:

- Resources with temperatures below $400^{\circ} \mathrm{F}$ are assumed to have pumped wells; resources with temperatures above $400^{\circ} \mathrm{F}$ are assumed to be free flowing.

- For pumped wells discharge pressure at the surface discharge flange is the maximum of: (a) Hot brine vapor pressure +50 psi or (b) pressure obtained from a standard pump discharge calculation which gives 143 psia at the surface discharge flange.

- There are no elevation changes between the plant site and the pumped well locations.

- There are no elevation changes between the plant site and the injection well locations.

- Well drawdown is based on a factor of $2,500 \mathrm{lb} /(\mathrm{hr}-\mathrm{psi})$. Submerged pumps are placed 150 feet under the calculated draw down levels.

- Gathering system costs are based on an estimated configuration and layout of the gathering system. Appendix A contains the gathering system calculation details.

- Production well drilling costs are adjusted according to the probabilities of hitting a dry hole listed in Table 4-1 for each resource.

- Injection pump discharge pressure is 100 psi plus the vapor pressure of the outlet brine.

- Injection pumps are sized to be $500 \mathrm{hp}$ maximum. A minimum of two $50 \%$ pumps are used. Whenever the pumping power exceeds the 500 hp limitation, another pump is added to the injection system. 
- Pumped wells have an average flow of $1500 \mathrm{gpm}$, and a maximum flow of $1550 \mathrm{gpm}$. Whenever the average well flow exceeds $1550 \mathrm{gpm}$, more wells are added to the field until the resulting well flow rate is below 1550 gpm.

- All heat exchanger costs are adjusted for pressure so that different pressure levels can be compared on the same basis.

- If required, the plant cost for open cycles includes the cost of a sulfur plant for $\mathrm{H}_{2} \mathrm{~S}$ abatement; $\mathrm{H}_{2} \mathrm{~S}$ emission is limited to $100 \mathrm{~g} / \mathrm{MWh}$. 
Table 4-1

EPRI Supplied Resource Data

\begin{tabular}{|c|c|c|c|c|c|}
\hline RS & 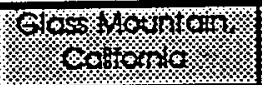 & \%ororog & 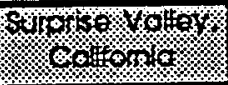 & 等 & $6 \%$ \\
\hline & & - & & + & \\
\hline \multirow{4}{*}{\begin{tabular}{|l|} 
Geothermal Fluid \\
Temperatures \\
\\
\\
\\
Initial \\
Final
\end{tabular}} & & $480^{\circ}-660^{\circ} \mathrm{F}$ & $338^{\circ}-428^{\circ} \mathrm{F}$ & $262^{\circ}-268^{\circ} \mathrm{F}$ & $320^{\circ}-340^{\circ} \mathrm{F}$ \\
\hline & & & & & \\
\hline & $510^{\circ} \mathrm{F}$ & $570^{\circ} \mathrm{F}$ & $375^{\circ} \mathrm{F}$ & $265^{\circ} \mathrm{F}$ & $330^{\circ} \mathrm{F}$ \\
\hline & $430^{\circ} \mathrm{F}$ & $480^{\circ} \mathrm{F}$ & $325^{\circ} \mathrm{F}$ & $235^{\circ} \mathrm{F}$ & $290^{\circ} \mathrm{F}$ \\
\hline \multirow{2}{*}{$\begin{array}{l}\text { Average Well } \\
\text { fowrate }\end{array}$} & $300^{\circ} \mathrm{Klbm} / \mathrm{hr}$ & $1,300 \mathrm{Klbm} / \mathrm{hr}$ & $500 \mathrm{klbm} / \mathrm{hr}$ & $300 \mathrm{~K}$ lbm/hr est. & $300 \mathrm{k} / \mathrm{bm} / \mathrm{hr}$ est. \\
\hline & & & & & \\
\hline TDS & 3800 ppm, floshed & $15-25 w+\%$ & $800-1,200 \mathrm{mg} / 1$ & $1.500 \mathrm{mg} / \mathrm{l}$ & $600-1200 \mathrm{mg} / \mathrm{l}$ \\
\hline \multirow{2}{*}{$\begin{array}{l}\text { Average Well Depth } \\
\text { Reservoir Pressure }\end{array}$} & $7,500 \mathrm{ft}$. & $6,000 \mathrm{f}$. & $5,000 \mathrm{ft}$ & $5000 \mathrm{ft}$ & $5,000 \mathrm{ft}$. \\
\hline & & & & & \\
\hline \multirow[t]{2}{*}{ Type } & underpressured & hydrostatic & hydrostatic & hydrostatic & hydrostatic \\
\hline & hydrostatic & & & & \\
\hline \multirow[t]{2}{*}{ AtDatum } & & $0.414 \mathrm{ps} / \mathrm{ft}$ & & & \\
\hline & & Pressure gradient & & & \\
\hline \multirow{3}{*}{$\begin{array}{r}\text { Average Well Cost } \\
\text { Producer } \\
\text { Injector }\end{array}$} & & & & & \\
\hline & S1.5M & $\$ 2.5 M$ & $\$ 1.5 \mathrm{M}$ & S1.5M & S1.5M \\
\hline & & & & & \\
\hline \multirow{2}{*}{$\begin{array}{l}\text { Percent Replacement } \\
\text { Wells Required }\end{array}$} & unknown & $2 \% / y /$ & $2 \% / y r$ & $2 \% / y r$ & $2 \% / \mathrm{rr}$ \\
\hline & & & & - & \\
\hline \multirow{2}{*}{$\begin{array}{l}\text { Minimum Reinjection } \\
\text { Temperature }\end{array}$} & $150^{\circ} \mathrm{F}$ & $220^{\circ} \mathrm{F}$ & - & - & - \\
\hline & & & & & \\
\hline Relative Corrosivity & Jow & high & very low & Jow & verylow \\
\hline \multirow[t]{2}{*}{ Scaling Potential } & low & high & low & low & low \\
\hline & & $1,360 \mathrm{ppm}$ & $>0.2$ wt. \% & $>2.0 w+\%$ & $>2.0 w t . \%$ \\
\hline \multirow{2}{*}{$\begin{array}{l}\text { Non-condensable } \\
\text { Gas Content - \% }\end{array}$} & $0.17 w t . \%$ & & & & \\
\hline & & & & & inknom \\
\hline \multirow{3}{*}{$\begin{array}{l}\text { Percent Dry Holes } \\
\text { Reservoir Can } \\
\text { Be Dispatched }\end{array}$} & est. $25 \%$ & none to date & $20-25 \%$ & $20 \%$ est. & unknown \\
\hline & Unknown & no & possible & possible & possible \\
\hline & & & & & \\
\hline \multicolumn{6}{|l|}{ Potential Energy } \\
\hline \multicolumn{6}{|l|}{30 years. MWe } \\
\hline open cycle & $\Rightarrow 500$ & $\Rightarrow 500$ (onstiore) & 350 & $50^{2}$ & $\Rightarrow 350$ \\
\hline closed cycle & $\Rightarrow 500$ & $\Rightarrow 500$ (onshore) & 500 & $50^{\circ}$ & $\Rightarrow 500$ \\
\hline USGS 790 est. & 750 by Ebosco & 3400 & 500 by Ebasco & $\begin{array}{c}\text { based on USGS } \\
790\end{array}$ & $8 \times 0$ \\
\hline & & & & assuming $33 \%$ eff. & \\
\hline Water availability & no & possible & possible & no & possible \\
\hline
\end{tabular}


Table 4-1

EPRI Supplied Resource Data (continued)

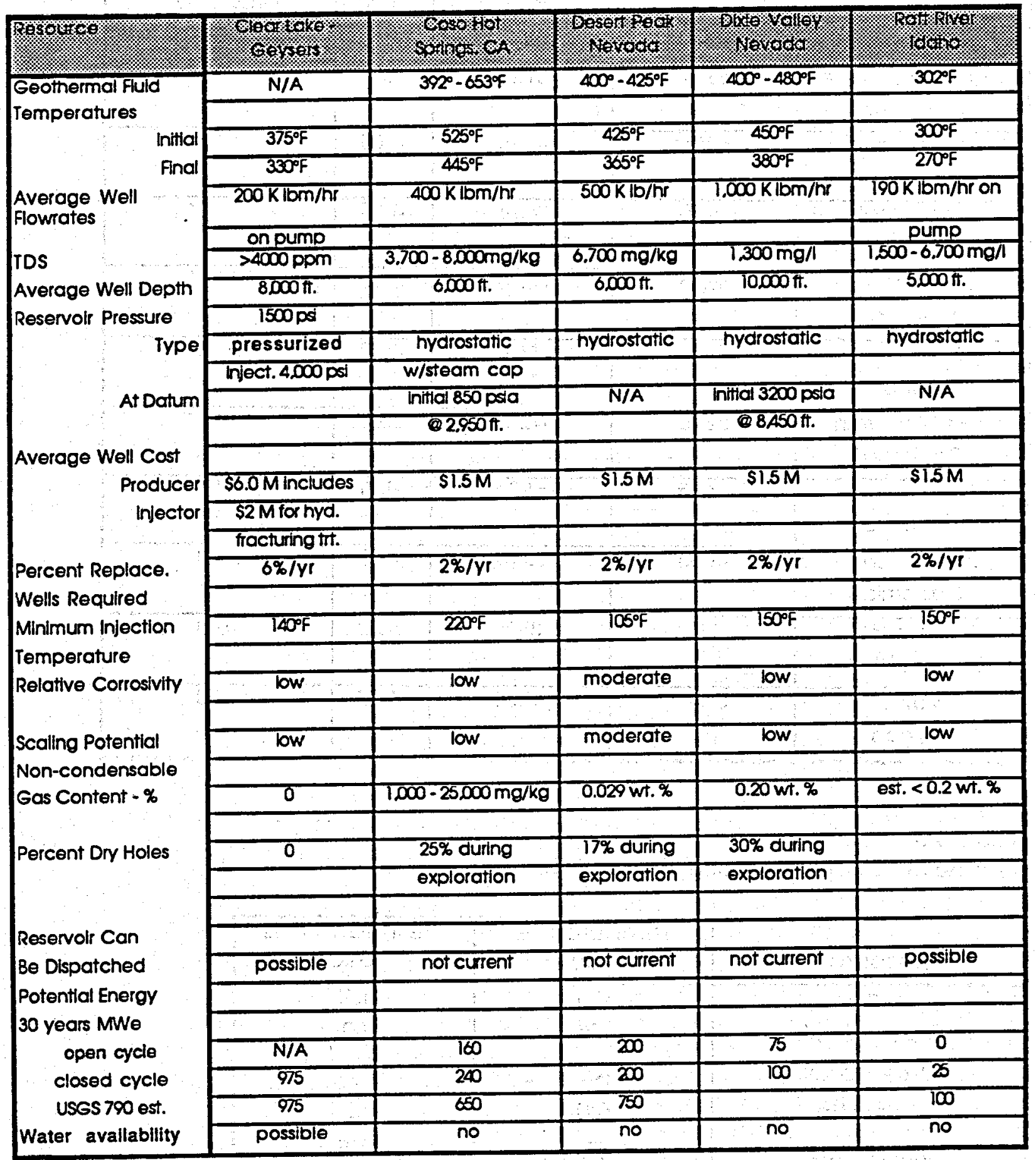


Table 4-2

Meteorological Data

\begin{tabular}{|c|c|c|c|c|}
\hline Site & $\begin{array}{l}\text { Avg Dry Bulb } \\
\text { Temp (F) }\end{array}$ & $\begin{array}{c}\text { Avg Wet Bulb } \\
\text { Temp ( })\end{array}$ & $\begin{array}{l}\text { Altitude } \\
\text { (ft) }\end{array}$ & $\begin{array}{l}\text { Drawdown } \\
\text { (lb / hr psi) }\end{array}$ \\
\hline $\begin{array}{c}\text { Clear Lake . Geysers } \\
\text { Califomia }\end{array}$ & 58.71 & 51.24 & 1630 & $1 .+6$ \\
\hline $\begin{array}{l}\text { Coso Hot Springs. } \\
\text { Califomia }\end{array}$ & 60.06 & 49.16 & 4200 & 8.000 \\
\hline $\begin{array}{l}\text { Desert Peak. } \\
\text { Nevada }\end{array}$ & 49.85 & 38.78 & 4600 & .00 \\
\hline $\begin{array}{l}\text { Dixie Valley. } \\
\text { Nevada }\end{array}$ & 49.85 & 38.78 & 3500 & $1+\ldots$ \\
\hline $\begin{array}{l}\text { Raft River. } \\
\text { Idaho }\end{array}$ & 47.17 & 38.4 & 4500 & 2500 \\
\hline $\begin{array}{c}\text { Glass Mountain. } \\
\text { Califomia }\end{array}$ & 52.75 & 46.23 & 5000 & 1.60 \\
\hline $\begin{array}{l}\text { Salton Sea, } \\
\text { Califomia }\end{array}$ & 74.05 & 56.24 & -100 & 0.60 \\
\hline $\begin{array}{c}\text { Surprise Valley. } \\
\text { Califomia }\end{array}$ & 49.85 & 38.78 & 4600 & 2500 \\
\hline $\begin{array}{l}\text { Thermo Hot } \\
\text { Springs. Utah }\end{array}$ & 49.2 & 38.5 & 5800 & 2500 \\
\hline $\begin{array}{l}\text { Vale, } \\
\text { Oregon }\end{array}$ & 51.43 & 41.25 & 4100 & 2500 \\
\hline
\end{tabular}

Table 4-3

Wellhead Pressures for Self Flowing Resources

\begin{tabular}{|c|c|c|}
\hline Resource & $\begin{array}{c}\text { Temperature } \\
\left({ }^{\circ} \mathrm{F}\right)\end{array}$ & $\begin{array}{c}\text { Wellhead Press } \\
\text { (psia) }\end{array}$ \\
\hline Coso & 525 & 130 \\
Desert Peak & 425 & 90 \\
Dixie Valley & 450 & 100 \\
Glass Mtn. & 510 & 151 \\
Salton Sea & 570 & 325 \\
\hline
\end{tabular}


Table 4-4

Noncondensable Gas Content of Geothermal Brine

\begin{tabular}{|c|c|c|}
\hline Site & $\begin{array}{c}\text { NCGs } \\
\text { wt ppm }\end{array}$ & H2S \\
wt ppm \\
\hline $\begin{array}{c}\text { Clear Lake-Geysers, } \\
\text { California }\end{array}$ & & \\
\hline $\begin{array}{c}\text { Coso Hot Springs, } \\
\text { California }\end{array}$ & 2000 & 105 \\
\hline $\begin{array}{c}\text { Desert Peak, } \\
\text { Nevada }\end{array}$ & 200 & 4 \\
\hline $\begin{array}{c}\text { Dlxil Valley, } \\
\text { Nevada }\end{array}$ & 2000 & 5 \\
\hline $\begin{array}{c}\text { Raft River, } \\
\text { Idaho }\end{array}$ & 2000 & 0.2 \\
\hline $\begin{array}{c}\text { Glass Mountain. } \\
\text { Calfomia }\end{array}$ & 1700 & 20 \\
\hline $\begin{array}{c}\text { Salton Sea. } \\
\text { Calfomia }\end{array}$ & 1360 & 16 \\
\hline $\begin{array}{c}\text { Surprise Valley, } \\
\text { Califomia }\end{array}$ & 2000 \\
\hline $\begin{array}{c}\text { Thermo Hot } \\
\text { Springs, Utah }\end{array}$ & 2000 \\
\hline $\begin{array}{c}\text { Vale. } \\
\text { Oregon }\end{array}$ & 2000 & 20 \\
\hline
\end{tabular}


Method of Approach

Table 4-5

Power Plant Multipliers

\begin{tabular}{|c|c|c|}
\hline \multirow[b]{2}{*}{ Site } & \multicolumn{2}{|c|}{ Installed Cost Multiplier } \\
\hline & $\begin{array}{l}\text { Binary/ } \\
\text { Kalina }\end{array}$ & $\begin{array}{l}\text { Flash/Flash } \\
\text { Derivatives }\end{array}$ \\
\hline $\begin{array}{c}\text { Clear Lake - Geysers, } \\
\text { California }\end{array}$ & 2.8 & 2.53 \\
\hline $\begin{array}{l}\text { Coso Hot Springs, } \\
\text { California }\end{array}$ & 2.8 & 2.53 \\
\hline $\begin{array}{l}\text { Desert Peak } \\
\text { Nevada }\end{array}$ & 2.8 & 2.53 \\
\hline $\begin{array}{c}\text { Dixie Valley, } \\
\text { Nevada }\end{array}$ & 2.8 & 2.53 \\
\hline $\begin{array}{l}\text { Raft River, } \\
\text { Idaho }\end{array}$ & 2.96 & 2.53 \\
\hline $\begin{array}{c}\text { Glass Mountain, } \\
\text { California }\end{array}$ & 2.8 & 2.53 \\
\hline $\begin{array}{l}\text { Salton Sea, } \\
\text { California }\end{array}$ & 2.8 & 2.53 \\
\hline $\begin{array}{c}\text { Surprise Valley, } \\
\text { California }\end{array}$ & 2.8 & 2.53 \\
\hline $\begin{array}{l}\text { Thermo Hot } \\
\text { Springs, Utah }\end{array}$ & 3.1 & 2.53 \\
\hline $\begin{array}{l}\text { Vale, } \\
\text { Oregon }\end{array}$ & 2.83 & 2.53 \\
\hline
\end{tabular}




\section{5}

\section{BASELINE TECHNOLOGIES}

\section{Air-cooled Commerclal Binary}

\section{Introduction}

Flash and binary cycles are the predominant technologies used for generation of geothermal electricity (Fridleifsson and Freeston, 1994). These two technologies were chosen to serve as baseline technologies in this study since they are proven technologies that find widespread commercial use and are well optimized. Throughout this report the terms commercial flash and commercial binary will represent the baseline flash and binary cycles, respectively. Both variations of the commercial binary cycle have been considered: air-cooled commercial binary and water-cooled commercial binary.

The commercial binary cycle is a Rankine cycle which uses a hydrocarbon as the working fluid, and is sometimes referred to as an organic Rankine cycle. This technology has been applied successfully to resources below $350^{\circ} \mathrm{F}$. The majority of binary cycle installations are air-cooled commercial binary cycles which rely on air-cooling for condensation of the working fluid. For example, power plants at Steamboat Springs, Nevada, and Mammoth, California are air-cooled commercial binary plants. A few installations where cooling water is available utilize the water-cooled commercial binary cycles. For example, the SIGC power plant at Heber is a water-cooled commercial binary plant.

A discussion of the air-cooled commercial binary cycle is presented in the following section; the next section discusses the water-cooled commercial binary cycle.

\section{Cycle Process Flow}

Figure 5-1 is the process flow diagram of the air-cooled commercial binary cycle. Hot geothermal fluid (brine) is used to heat and vaporize a working fluid in a series of heat exchangers. The hot working fluid vapor is then expanded through a turbine to generate electricity. The turbine exhaust is subsequently condensed in an air-cooler. The cycle is complete when the condensed working fluid is pumped back to be heated by the hot brine. 
Binary cycles in this study were modeled using commercial isobutane as the working fluid. This is a common working fluid in binary cycle power plants. The working fluid was assumed to be composed of 96.06 mole percent isobutane, 1.77 mole percent normal butane, and 2.17 mole percent propane.

\section{Performance Analysis}

\section{Description}

As noted in Section 4 the optimum cycle was identified by performing process calculations for several cases for each plant site. For the binary cycles these calculations were performed using a proprietary Holt model that incorporates the BWR/Starling equation of state. This model computes thermodynamic state points, power output, brine flow requirements, and parasitic loads for binary cycles, and was used in this study to calculate these quantities for a $50 \mathrm{MW}$ (net) power plant design. The results of the model calculations were used to obtain specific output for various process cases.

The calculations for final resource conditions were performed assuming constant turbine inlet volume. Turbine inlet mass flow rate and pressure were adjusted to maintain a constant volumetric flow rate, and the turbine efficiency was reduced to simulate off-design conditions.

\section{Assumptions}

General modeling assumptions, i.e. assumptions used to evaluate the performance of all the concepts considered in this study are listed in Section 4. For example, basic resource and weather data used for these calculations are listed in Table 4-1 and 4-2. The following assumptions apply specifically to binary plant performance calculations:

- Commercial isobutane is the working fluid.

- The air condenser was sized to give a $34{ }^{\circ} \mathrm{F}$ approach on the cold end with a $14.8{ }^{\circ} \mathrm{F}$ pinch unless a greater pinch was required to avoid a temperature cross in the heat exchanger.

- Condenser pressure drop: 6 psi (3 psi hydraulic drop +3 psi to account for the inevitable presence of noncondensables in the working fluid loop)

- Turbine adiabatic efficiency: $85.0 \%$

- Working fluid pump efficiency: $80 \%$.

- Generator efficiency: $94.0 \%$

- Hydrocarbon loop pressure drop: 50 psi (includes pressure drop for piping, control valve, and heat exchangers) 


\section{Economic Analysis}

The power pant capital cost was calculated using a spreadsheet template (the cost spreadsheet). This spreadsheet calculates the cost of each major equipment item for the designed binary plant based on vendor data and proprietary Holt data. It then uses the major equipment costs along with the wellfield costs to calculate the facility capital cost and the specific capital cost as discussed in Section 4.

A Holt model was used to design brine gathering and injection systems, and to estimate the gathering system installation and construction costs. Another Holt model was used to calculate parasitic power requirements for each submerged well pump. Details of these two Holt models are presented in Appendix A.

\section{Results}

Optimum geothermal power plants using the air-cooled commercial binary cycle were designed for Thermo Hot Springs, Raft River, Vale, Surprise Valley and Glass Mountain. Application of the air-cooled commercial binary cycle for the remaining sites was ruled out by inspection.

Specific power production curves for Thermo Hot Springs, Raft River, Vale, Surprise Valley and Glass Mountain are presented collectively in Figure 5-2. Figure 5-2 indicates that the maxima in the specific output must closely approximate the cycle optimum since, as the figure shows, specific output does not change significantly with pressure. In other words, cycle performance is a relatively flat function of turbine inlet pressure over the range of variables studied. Specific output for the optimum cycles obtained from Figure 5-2 is plotted as a function of resource temperature in Figure 5-3 which shows that the binary cycle specific output increases with resource temperature.

Table 5-1 summarizes the results of the economic analysis of the air-cooled commercial binary cycle for various resources. Specific output and turbine inlet pressures for the optimum cycles are also listed in the table. As can be observed from the table, specific capital cost is inversely related to specific output since a decrease in specific output increases wellfield costs which are a significant fraction of facility capital cost. The results of plant power production with final resource temperature are presented in Table 5-2.

The trend of specific capital cost versus resource temperature is shown in Figure 5-4. 


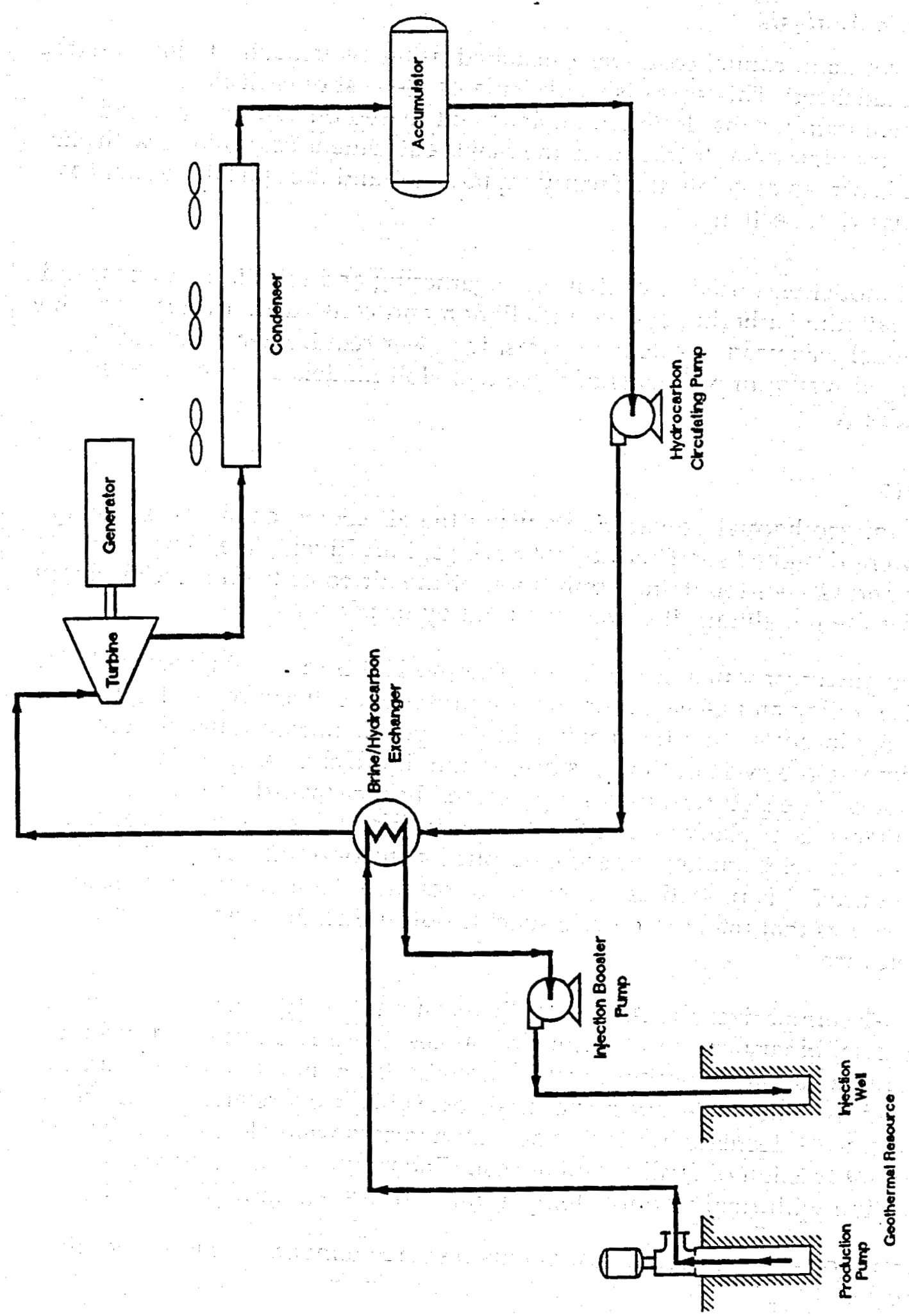

Figure 5-1

Air-cooled Commercial Binary Cycle: Process Flow Diagram 


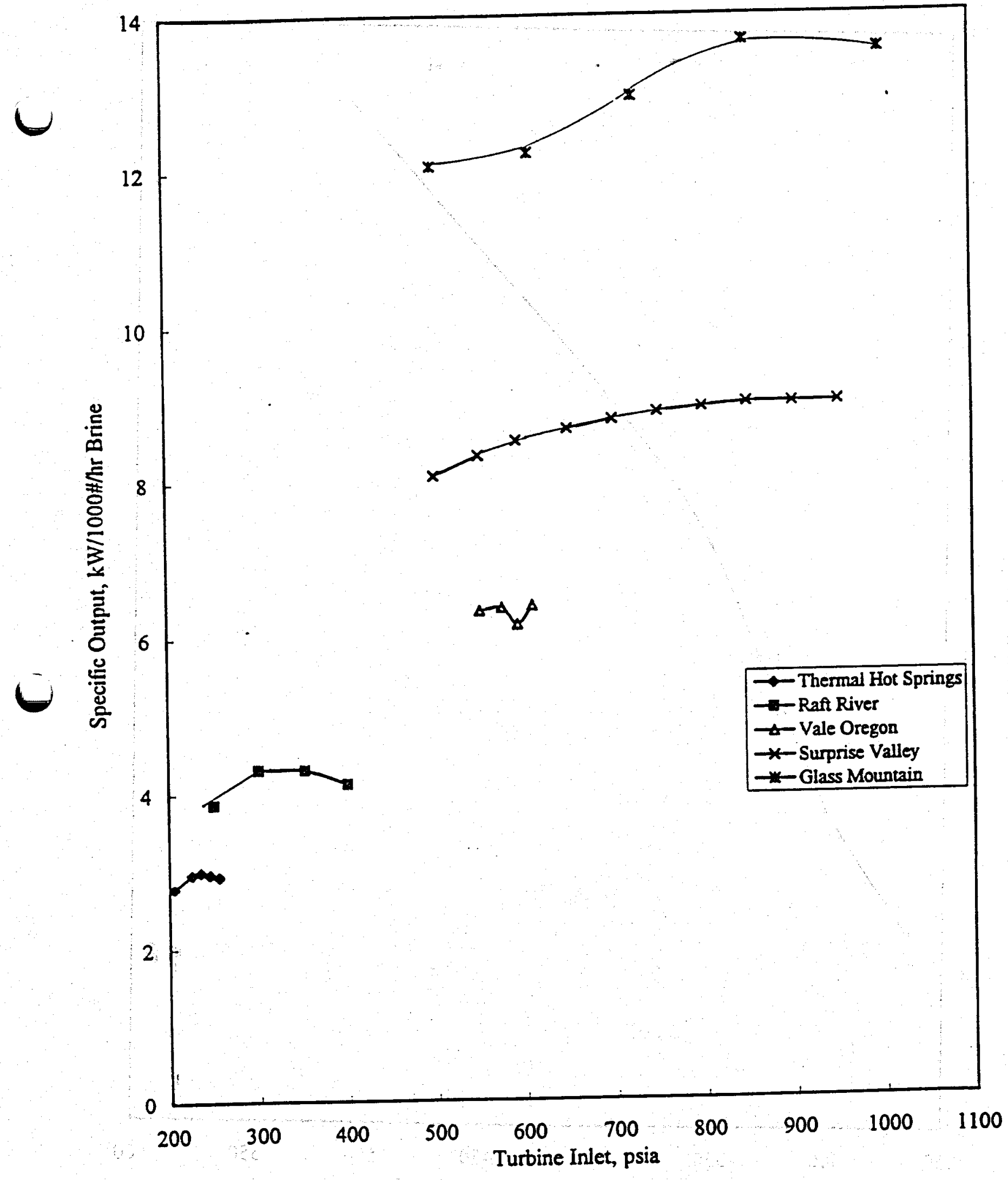

Figure 5-2

Air Cooled Commercial Binary: Specific Output Curves 


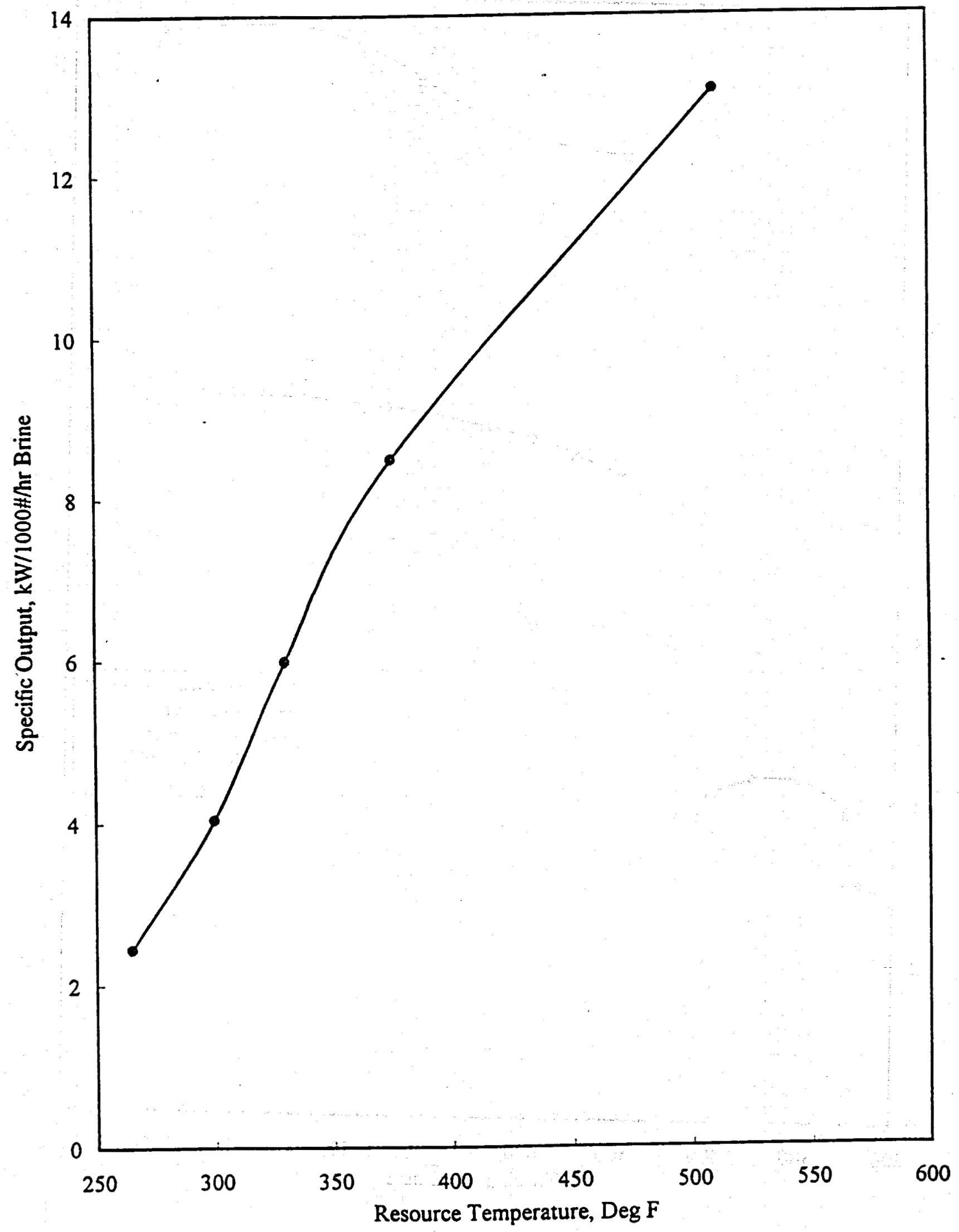

Figure 5-3

Air-cooled Commercial Binary Cycle: Specific Output v Resource 
Table 5-1

Air-cooled Commercial Binary: Summary of Cases

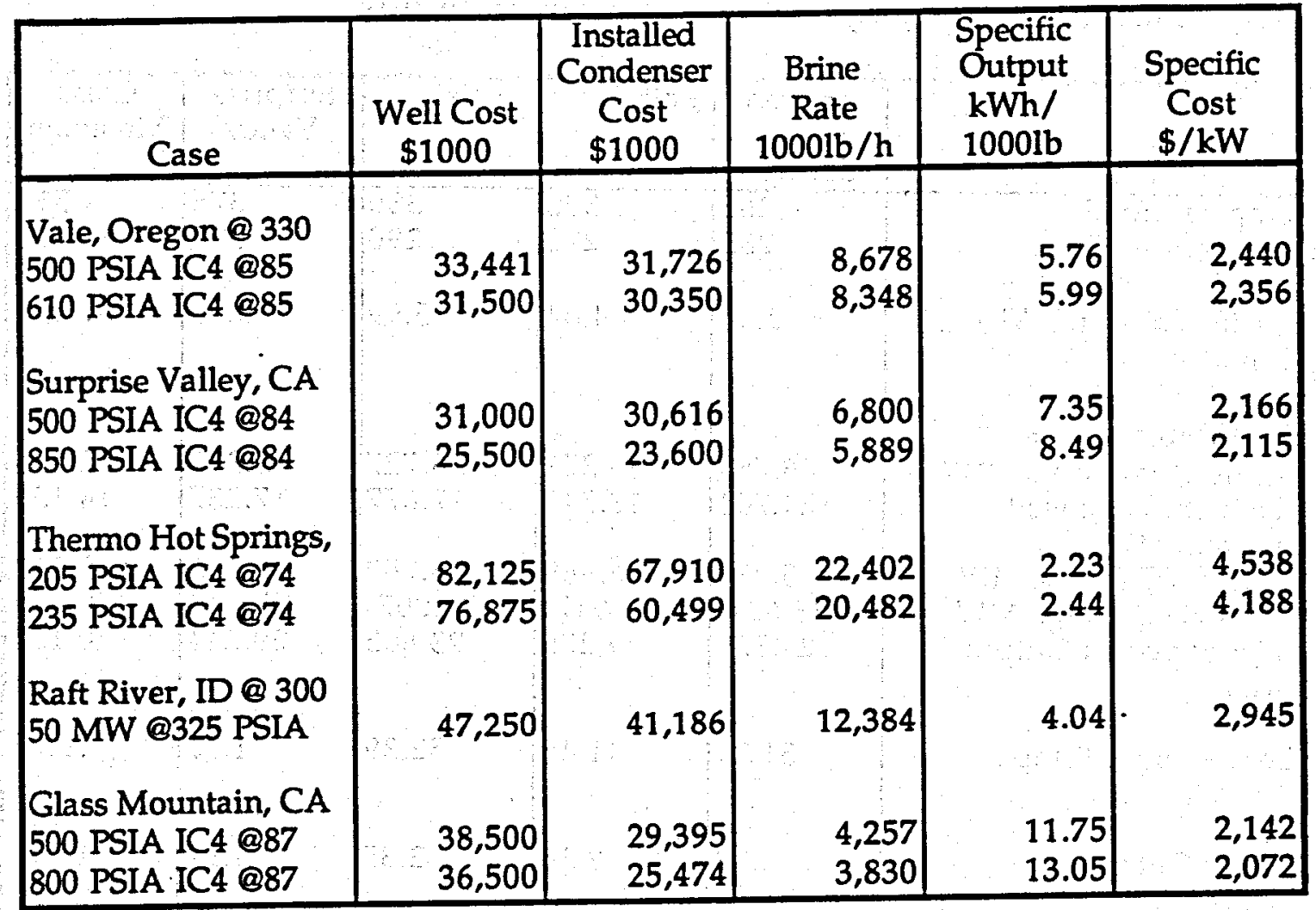


Table 5-2

Air-cooled Commercial Binary Cycle: End of Reservoir Results

\begin{tabular}{|c|c|c|c|c|c|}
\hline & $\begin{array}{l}\text { Thermo } \\
\text { Hot } \\
\text { Springs }\end{array}$ & Raft River & Vale & $\begin{array}{l}\text { Surprise } \\
\text { Valley }\end{array}$ & $\begin{array}{c}\text { Glass } \\
\text { Mountain }\end{array}$ \\
\hline $\begin{array}{l}\text { Initial Temperature, }{ }^{\circ} \mathrm{F} \\
\text { Final Temperature, }{ }^{\circ} \mathrm{F}\end{array}$ & $\begin{array}{l}265 \\
235\end{array}$ & $\begin{array}{l}300 \\
270\end{array}$ & $\begin{array}{l}330 \\
290\end{array}$ & $\begin{array}{l}375 \\
325\end{array}$ & $\begin{array}{l}510 \\
430\end{array}$ \\
\hline $\begin{array}{l}\text { Initial Specific Output, kWh/ } \\
1000 \mathrm{lb} \text { brine }\end{array}$ & 2.44 & 4.04 & 5.99 & 8.50 & 13.05 \\
\hline $\begin{array}{l}\text { Net at Final Temperature } \\
\text { Generator Output, MW } \\
\text { Parasitics (inc well }\end{array}$ & $\begin{array}{l}46.753 \\
24.704\end{array}$ & $\begin{array}{l}45.371 \\
18.548\end{array}$ & $\begin{array}{l}36.727 \\
17.677\end{array}$ & $\begin{array}{l}43.318 \\
17.237\end{array}$ & $\begin{array}{l}52.443 \\
14.136\end{array}$ \\
\hline $\begin{array}{l}\text { pump), MW } \\
\text { SOR H/C Pump, MW } \\
\text { EOR H/C Pump, MW } \\
\text { Net Expected Output, } \\
\text { MW }\end{array}$ & $\begin{array}{r}5.934 \\
(3.604) \\
24.379\end{array}$ & $\begin{array}{r}6.369 \\
(3.917) \\
29.275\end{array}$ & $\begin{array}{r}8.762 \\
(4.007) \\
23.805\end{array}$ & $\begin{array}{l}10.283 \\
(7.120) \\
29.244\end{array}$ & $\begin{array}{r}9.962 \\
(8.135) \\
40.134\end{array}$ \\
\hline $\begin{array}{l}\text { Power Loss at Final Temp., } \\
\text { Percent }\end{array}$ & 51.24 & 41.45 & 52.39 & 41.51 & 19.73 \\
\hline $\begin{array}{l}\text { Final Specific Output, } \\
\text { kWh/1000lb brine }\end{array}$ & 1.19 & 2.36 & 2.85 & 4.97 & 10.48 \\
\hline
\end{tabular}




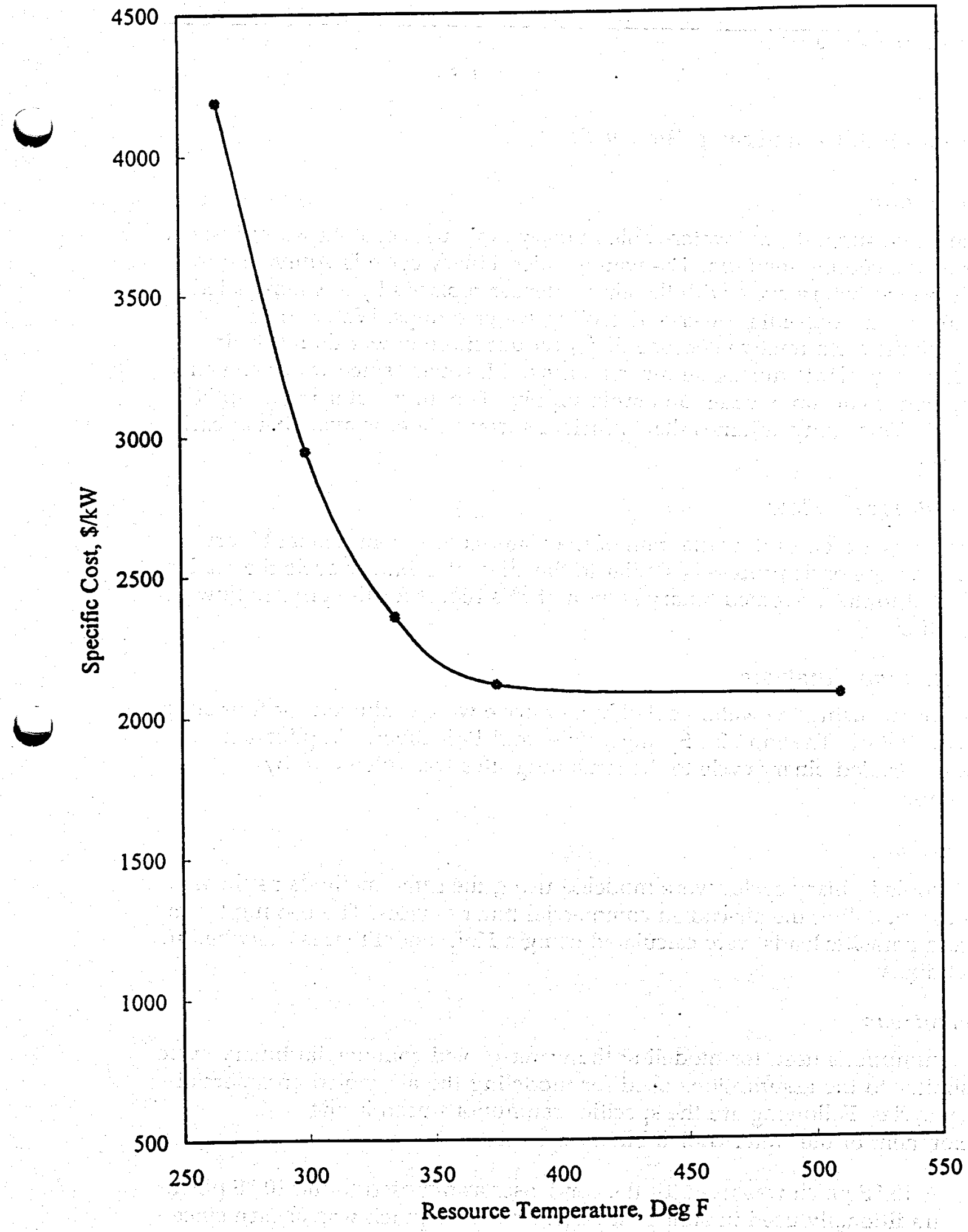

Figure 5-4

Air-cooled Commercial Binary Cycle: Specific Capital Cost v.

Resource Temperature 


\section{Water-cooled Commercial Binary}

\section{Introduction}

As the name suggests, the water-cooled binary cycle uses cooling water instead of air as the cooling medium. The water-cooled binary cycle is equivalent to the air-cooled binary cycle with the air condenser replaced by a water-cooled condenser plus a cooling tower and cooling water pumps. Water-cooled binary plants are attractive because they produce more power than the air cooled binary plants during summer months. However, since water-cooled binary plants consume water, an ample supply of cooling water make-up is required. This study assumes that sufficient surface water is available at each resource.

\section{Cycle Process Flow}

Figure 5-5 is a process flow diagram of the water-cooled commercial binary cycle. Since the basic process is similar to the air-cooled binary cycle the reader is referred to the air-cooled binary section of this report for the process flow description.

\section{Performance Analysis}

Power plants using the water-cooled binary cycle were evaluated for four sites: Surprise Valley, Thermo Hot Springs, Vale, and Raft River. Application of the water-cooled binary cycle to the remaining sites was ruled out by inspection.

\section{Description}

Water-cooled binary cycles were modeled using the same methods as those used for modeling the air-cooled commercial binary cycles. The cooling tower size and parasitic loads were calculated using a Holt model that is described in Appendix A.

\section{Assumptions}

The assumptions used for modeling the water-cooled commercial binary cycle are similar to the assumptions used for modeling the air-cooled commercial binary cycles. Following are the specific assumptions used in the development of the water-cooled binary cycles:

- A $15^{\circ} \mathrm{F}$ pinch was used for the condenser as opposed to the $10^{\circ} \mathrm{F}$ pinch traditionally used in similar studies. The $15{ }^{\circ} \mathrm{F}$ pinch was chosen since it gave the minimum specific capital cost as shown in Figure 5-6.

- Cooling tower make-up water was assumed to be available at no cost. 
- The condensing temperature was taken as the average wet bulb temperature $+10^{\circ} \mathrm{F}$ cooling tower approach $+15^{\circ} \mathrm{F}$ cooling water rise + $15^{\circ} \mathrm{F}$ condenser hot end approach (i.e. wet bulb temperature $+40^{\circ} \mathrm{F}$ ).

- The cooling tower is a counterflow type tower using high efficiency film fill.

\section{Cost Analysis}

Water cooled binary cycle power plants were evaluated by simulating six to ten cases for each site over a range of turbine inlet pressures. From these cases, four cases, corresponding to the highest specific output, were selected for equipment sizing and calculation of specific capital cost. The economic optimum was then found from a plot of specific capital cost verses operating pressure. For general details of cost analysis refer to the cost analysis section of the air cooled binary cycle.

\section{Results}

Specific power production curves for Thermo Hot Springs, Raft River, Vale, and Surprise Valley are presented collectively in Figure 5-7. Figure 5-7 shows that the maximum specific output increases with increasing resource temperature. Also, the pressure at which the thermodynamic optimum occurs increases with increasing resource temperature. The corresponding specific capital cost curves are presented in Figure 5-8.

A comparison of the Figures 5-7 and 5-8 indicates that except for Thermo Hot Springs the maxima in specific output do not coincide with the specific capital cost minima. The same conclusion can be reached by examining Table 5-3 which summarizes turbine inlet pressures for maximum specific output cases and minimum specific capital cost cases. The maximum specific output cases do not always yield minimum capital cost due to the fact that incremental increases in specific output are offset by increased costs associated with increases in pressures and decreases in exchanger LMTDs.

Table 5-4 presents a comparative summary of optimum cycles for the aircooled and water-cooled commercial binary cycles. The table shows that the specific capital cost of water-cooled binary cycle power plants is only marginally less than that of air-cooled binary cycle plants. The two cycles have similar specific capital costs because water-cooled binary cycle parasitic loads (of the cooling tower and water pumps) are higher than comparable aircooled binary cycle parasitic loads (fin fan). Also, the specific output of watercooled binary cycles is less than that of air-cooled binary cycles (see Table 5-4). 


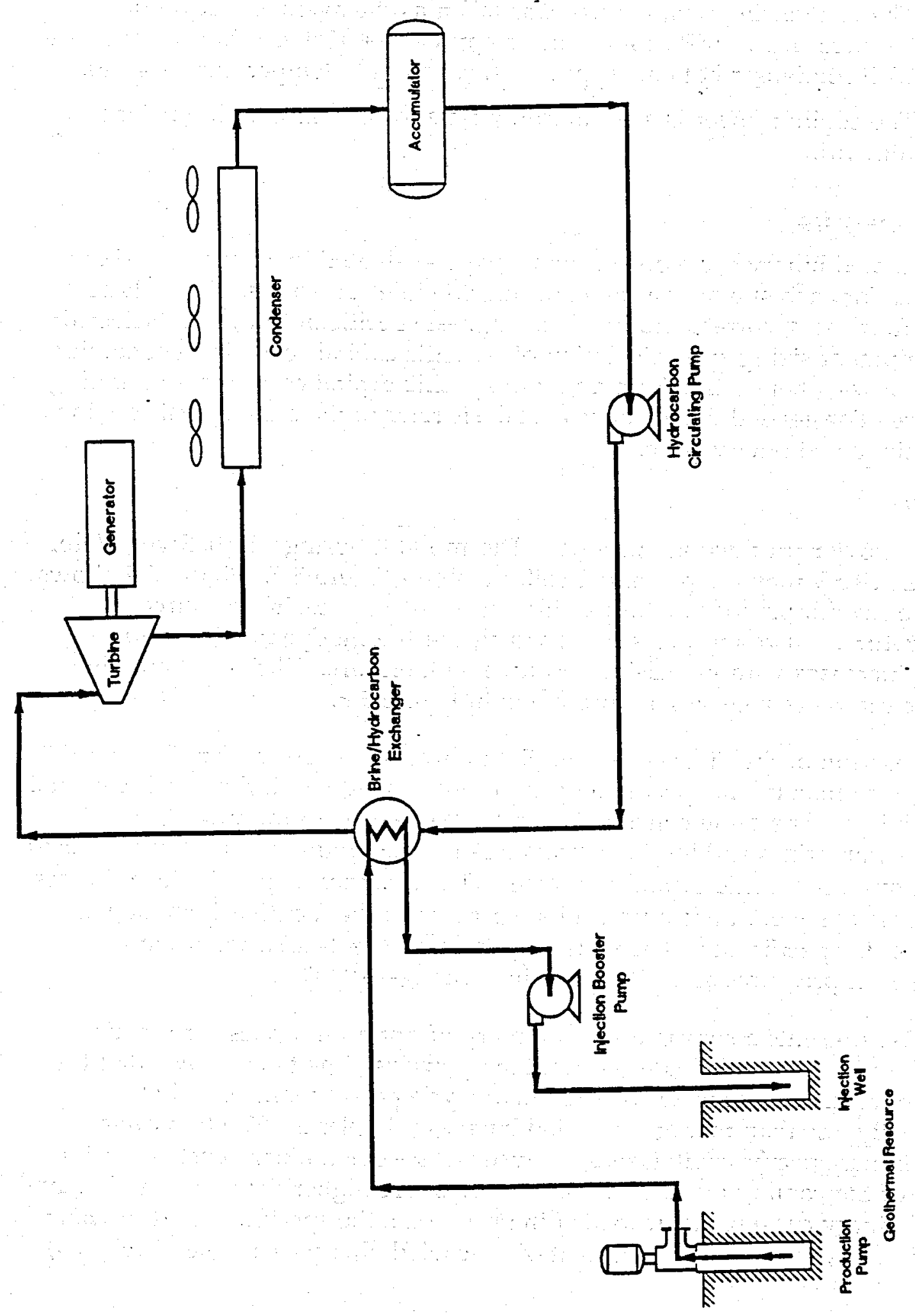

Figure 5-5

Water-Cooled Commercial Binary Cycle: Process Flow Diagram 


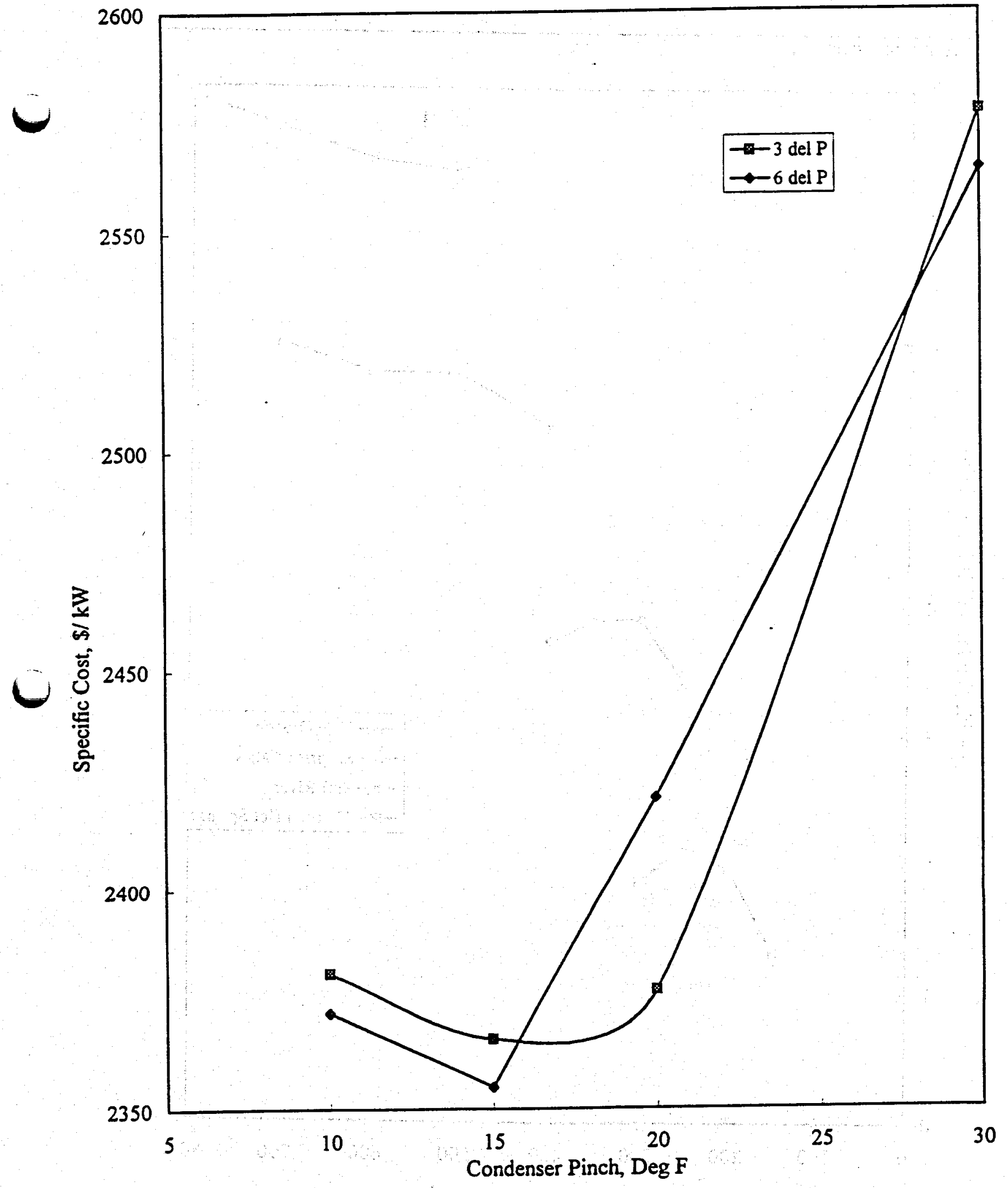

Figure 5-6

Specific Capital Cost v. Condenser Pinch: Vale, Oregon 


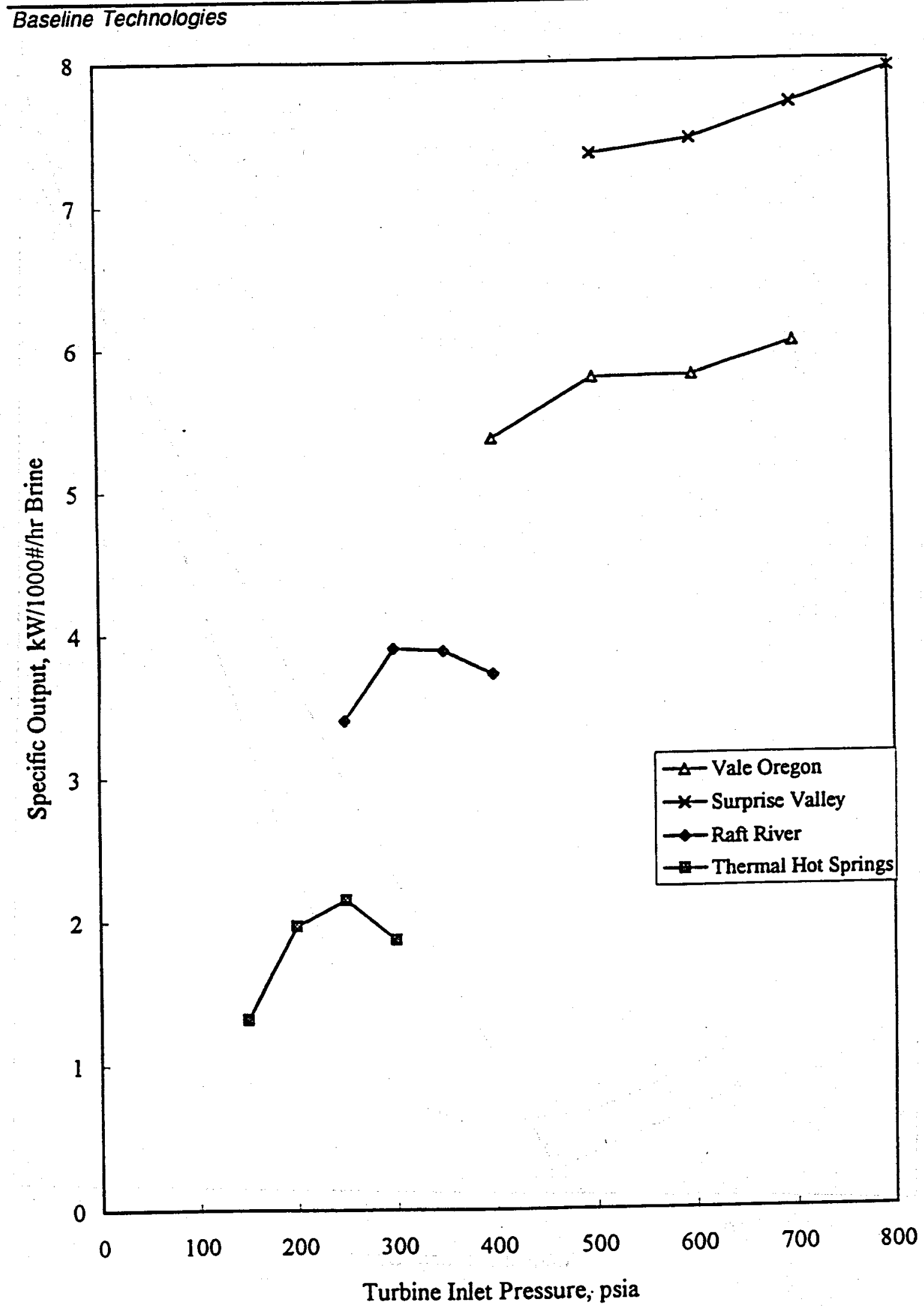

Figure 5-7

Water Cooled Binary: Specific Output v. Turbine Inlet Pressure 


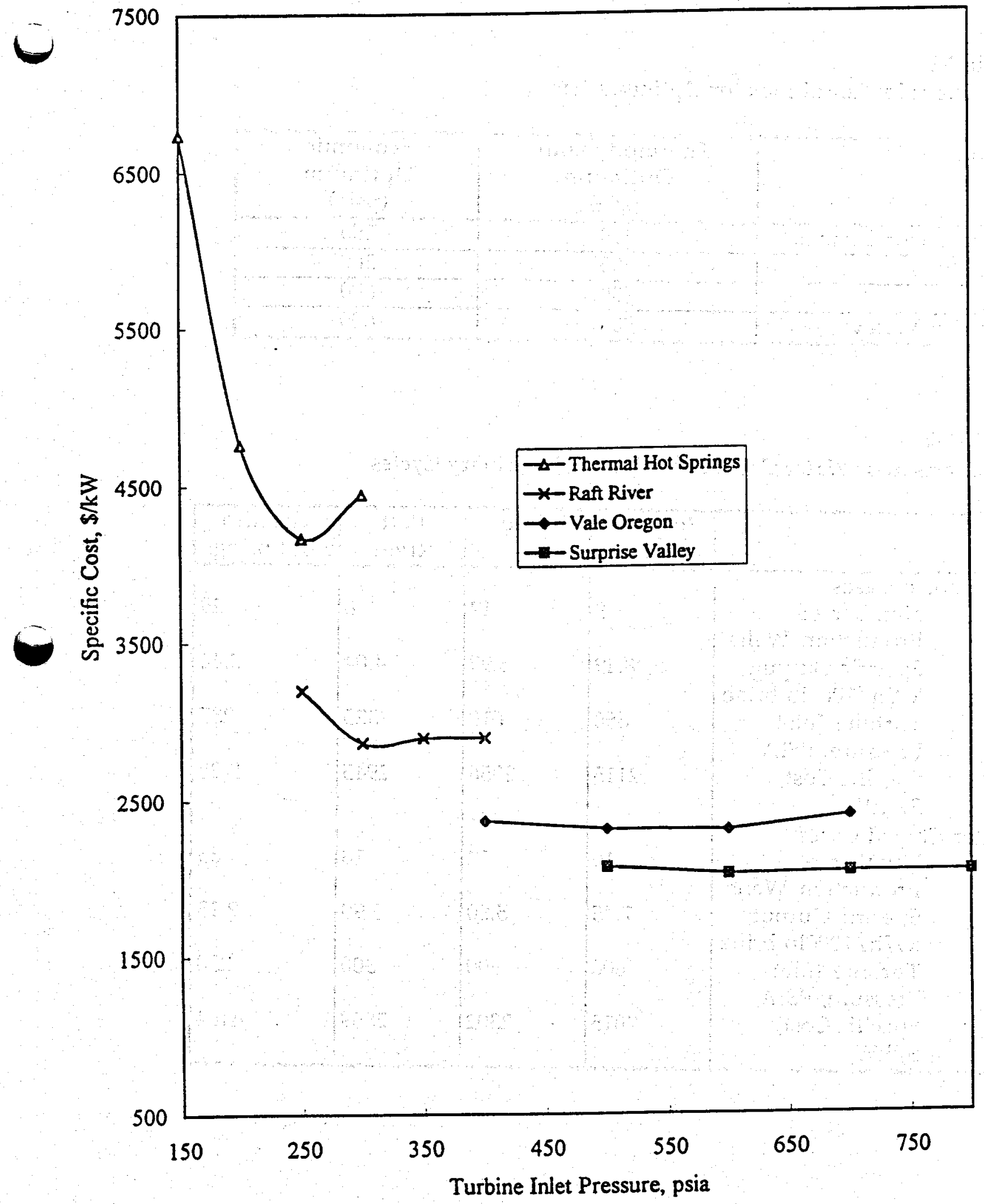

Figure 5-8

Water Cooled Binary: Specific Cost v. Turbine Inlet Pressure 
Table 5-3

Turbine Inlet Conditions for Optimum Cases

\begin{tabular}{|l|c|c|}
\hline Resource & $\begin{array}{c}\text { Thermodynamic } \\
\text { Optimum } \\
\text { (psia) }\end{array}$ & $\begin{array}{c}\text { Economic } \\
\text { Optimum } \\
\text { (psia) }\end{array}$ \\
\hline Thermo Hot Springs & 250 & 250 \\
\hline Raft River & 350 & 300 \\
\hline Vale & 700 & 600 \\
\hline Surprise Valley & 900 & 600 \\
\hline
\end{tabular}

Table 5-4

Comparison of Water Cooled and Air Cooled Binary Cycles

\begin{tabular}{|c|c|c|c|c|}
\hline & $\begin{array}{c}\text { Surprise } \\
\text { Valley }\end{array}$ & Vale & $\begin{array}{c}\text { Raft } \\
\text { River }\end{array}$ & $\begin{array}{c}\text { Thermo } \\
\text { Hot Springs }\end{array}$ \\
\hline $\begin{array}{l}\text { Air Cooled Cases } \\
\text { Number of } \\
\text { Production Wells } \\
\text { Specific Output, } \\
\text { kWh/1000lb brine } \\
\text { Turbine Inlet } \\
\text { Pressure, PSIA } \\
\text { Specific Cost, } \\
\text { \$/kW } \\
\text { Water Cooled Cases } \\
\text { Number of } \\
\text { Production Wells } \\
\text { Specific Output, } \\
\text { kWh/1000lb brine } \\
\text { Turbine Inlet } \\
\text { Pressure, PSIA } \\
\text { Specific Cost, } \\
\text { \$/kW }\end{array}$ & $\begin{array}{r}9 \\
8.49 \\
850 \\
2115 \\
10 \\
7.45 \\
600 \\
2015\end{array}$ & $\begin{array}{r}12 \\
5.99 \\
610 \\
2356 \\
12 \\
5.80 \\
600 \\
2302\end{array}$ & $\begin{array}{r}18 \\
4.04 \\
325 \\
2945 \\
18 \\
3.90 \\
300 \\
2869\end{array}$ & $\begin{array}{r}29 \\
2.44 \\
235 \\
4188 \\
33 \\
2.15 \\
250 \\
4164\end{array}$ \\
\hline
\end{tabular}




\section{Commercial Dual Flash}

\section{Introduction}

Dual flash technology finds wide application in the geothermal power industry. The analysis of dual flash technology serves to provide a useful baseline for evaluating competing NGGPP technologies. In fact, many of the next generation technologies investigated in this study are modifications of the commercial dual flash process.

\section{Cycle Process Flow}

Figure 5-9 is a process flow diagram for the standard dual flash geothermal power plant. Geothermal brine flows through a throttle valve to a high pressure flash separator. High pressure steam from the separator overhead is expanded through the high pressure sections of one or more dual exhaust axial flow turbines which produce useful work. A portion of the high pressure stream from the separator is diverted to the vacuum system which uses steam ejectors to draw the non-condensable gases from the condenser to create a vacuum.

Saturated liquid from the high pressure separator bottom flows through another pressure reducing valve to a low pressure separator. Low pressure steam from the separator overhead then flows to the turbine(s) where it is combined with partially spent high pressure steam to produce work in the low pressure turbine sections. The liquid from the low pressure separator bottom is pumped to the injection wells for return to the reservoir.

Steam from the turbine exhaust is condensed in a water-cooled condenser. The condenser is a direct contact type condenser unless high $\mathrm{H}_{2} \mathrm{~S}$ flow mandates the use of a surface condenser. Most of the condensate and the cooling water returned from the condenser outlet is pumped back to the cooling tower. The excess liquid is injected into the geothermal reservoir along with the residual brine.

Non-condensable gases removed from the main condenser are discharged from the plant at roughly atmospheric pressure by the vacuum equipment. The gases are dispersed in the cooling tower fan stacks unless the $\mathrm{H}_{2} \mathrm{~S}$ concentration requires abatement. In this case, the gases are first sent to a liquid redox type sulfur plant.

\section{Performance Analysis}

To assess its performance, dual flash technology was applied to all sites except Thermo Hot Springs and Clear Lake Geysers. Both sites were eliminated by inspections because the resource at Thermo Hot Springs is a relatively cool resource $\left(265^{\circ} \mathrm{F}\right)$, and the resource at Clear Lake is hot dry rock. 


\section{Description.}

This study used an in-house Holt performance model to evaluate commercial dual flash technology. Geothermal power plants currently in operation have been designed using this model. Several dual flash power plant designs were generated using the Holt model in order to locate the optimum dual flash power plant design for each geothermal site. Important model parameters that were optimized include flash pressures and condenser temperature.

Although flash pressures were varied to maximize specific output, the range of flash pressures was constrained. For free flowing resources the maximum flash pressure was set by the wellhead pressure. Wellhead pressures for these resources are listed in Table 4-3. Furthermore, the maximum high pressure flash pressure was limited to 153 psia since this study assumes that steam turbine inlet temperatures cannot exceed $360^{\circ} \mathrm{F}$ due to metallurgical limitations. Finally, low pressure turbine inlet pressures were constrained to a lower limit of one atmosphere to prevent air leakage into the process since this is the current industry standard practice.

Cooling water flow rate to the main condenser was varied to maximize power plant specific output. Increasing cooling water flow tends to increase power output by lowering condenser pressure. However, as condenser pressure falls the vacuum system load rises, increasing consumption of high pressure steam in the vacuum system. Also, the parasitic load of the cooling water pumps increase.

\section{Assumptions}

General modeling assumptions are listed in Table 4-1 and Table 4-2. The following data were obtained from these tables:

- Brine inlet and minimum rejection temperature

- Well costs

- Total dissolved solids content

- Site altitude

- Wet bulb and dry bulb temperatures

- Well flow rate for self-flowing wells.

The noncondensable gas content for each resource is listed in Table 4-4. In addition the following assumptions were made in modeling commercial dual flash power plants:

- Minimum pressure drops in the steam lines from the high and low pressure separators to the turbine were set at 2.2 psi and 1 psi, respectively.

- The minimum approach temperatures for the cooling tower and the condenser were assumed to be $5^{\circ} \mathrm{F}$. 
The following values obtained from vendor data (Fujl Electric Co.) were used in this study:

- $\quad$ Group stage efficiencies of the high and low pressure turbine stage groups were taken to be $83 \%$ and $85 \%$, respectively.

- The mechanical efficiency was assumed to be $97.5 \%$ to account for generator and bearing losses.

- Exhaust losses were calculated as a function of exhaust velocity. 27 inches was the largest allowable last stage blade diameter.

\section{Economic Analysis}

As discussed in Section 4, facility capital costs for all technologies were calculated using the factored method: the installed cost for major equipment is calculated by multiplying the equipment cost by a site-specific plant cost factor. For dual flash power plants the value of the multiplier was 2.53 for all technologies. To determine the optimum dual flash plant configuration a number of cycle parameters were varied:

- Condenser type

- Vacuum system type

- Turbine number

- Cooling water circulation

The results of dual flash plant optimization are summarized in Tables 5-5 and 5-6. Important optimization parameters are discussed below.

Two types of condensers were considered for dual flash plants, surface condensers and direct contact condensers. The type of condenser that can be used in a dual flash plant depends on the hydrogen sulfide content of the geothermal fluid. For resources that yield $\mathrm{H}_{2} \mathrm{~S}$ flow rates less than $66 \mathrm{lb} / \mathrm{hr}$ for a $50 \mathrm{MW}$ plant, a direct contact condenser was specified since, at that flow rate, $\mathrm{H}_{2} \mathrm{~S}$ emissions can be kept below the $11 \mathrm{lb} / \mathrm{hr}$ limit with a direct contact condenser. For resources that yield a hydrogen sulfide flow rate greater than $66 \mathrm{lb} / \mathrm{hr}$, surface condensers were used.

The cost of direct contact condensers is a function of the total duty whereas surface condenser costs were calculated as a function of surface area. The condenser approach temperatures were also optimized for each resource since reducing the approach temperature increases power output but also increases the required condenser surface area. As an illustration, the specific plant cost versus condenser approach temperature is plotted for Vale, Oregon in Figure 5-10. The figure shows that $7.5^{\circ} \mathrm{F}$ is the most economical condenser approach temperature for Vale. The optimum approach temperatures for each site are listed in Table 5-6. 
Vacuum system type is another optimization parameter used in the design of dual flash plants. Two vacuum system configurations were considered:

- two stage ejector system

- three stage hybrid system, with a vacuum pump as the third stage.

In general, higher specific output is obtained with the three stage hybrid system compared to the two stage ejector system but the vacuum pump adds to the cost. The three stage hybrid system is cost effective when the vapor/gas flow rate into the condenser is high for low temperature resources and for resources with high noncondensable gas concentration.

Figure 5-11 compares the specific plant cost for plants using the two types of vacuum system for several resources. It can be seen that the two systems are equally cost effective at a resource temperature of $375^{\circ} \mathrm{F}$ (Surprise Valley). For resource temperatures below $375^{\circ} \mathrm{F}$, plants using the three stage hybrid system are somewhat lower in cost than plants using two stage jets; the converse is true for resource temperatures above $375^{\circ} \mathrm{F}$.

As discussed in the performance analysis section, cooling water circulation rate was adjusted to optimize condenser operation. A number of cases were run for each resource with varying cooling water flow rates to obtain the optimum cooling water flow rate. As an illustration, a plot of cooling water circulation versus specific plant cost is shown on Figure 5-12 for Vale, Oregon. As can be seen from the figure, the optimum cooling water flow rate is $96,000 \mathrm{gpm}$ for Vale. The optimum cooling water flow rates for each site are listed in Table 5-6.

\section{Results}

\section{Performance}

Specific output for various resources is shown on Figure 5-13. It can be seen from the figure that a dual flash plant at Salton Sea $\left(570^{\circ} \mathrm{F}\right)$ would yield the maximum specific power output $(18 \mathrm{~kW} / 1000 \mathrm{Lb} / \mathrm{hr})$; the minimum specific power output $(1.2 \mathrm{~kW} / 1000 \mathrm{lb} / \mathrm{hr})$ would be obtained at Thermo Hot Springs $\left(265^{\circ} \mathrm{F}\right)$.

Figure 5-13 shows that, in general, specific output increases with resource temperature. However, the characteristics of individual resources have a significant effect on specific output. For example, the geothermal brine at Coso Hot Springs contains a larger amount of noncondensable gases ( $2 \% \mathrm{wt})$ which affects the size and cost of the vacuum system. Consequently, the specific output of a dual flash plant at Coso is lower than that for a resource of equal temperature but lower non-condensable gas content. Similarly, the presence of large amounts of dissolved solids (15-25\% wt) in the brine has an adverse effect on the specific output of a dual flash plant at Salton Sea. 
Resources below $400^{\circ} \mathrm{F}$ are pumped resources. The well pumping power requirement reduces the specific output for these resources relative to resources with free flowing wells. Moreover, the low pressure flash pressure for these cooler resources is constrained to a lower limit of one atmosphere which may not be thermodynamically favorable.

\section{Economics}

Using the optimum configurations listed in Table 5-5 and Table 5-6, specific capital costs (for a nominal $50 \mathrm{MW}$ plant) were obtained for each resource and are presented in Figure 5-14. Some general observations on the dependence of specific capital cost on resource types are discussed below.

In general, specific capital cost is dependent on resource temperature and other characteristics in a manner similar to specific output as discussed above. Thus, for example, although Coso Hot Springs is a relatively hot resource, a dual flash plant at Coso would have a higher specific capital cost due to the presence of larger amounts of non-condensable gases and $\mathrm{H}_{2} \mathrm{~S}$ in the brine.

For self-flowing wells, the average well flow rate has a significant effect on capital cost since well flow rate largely determines the number of wells, and low well flow rates translate into larger wellfield costs. This phenomenon is highlighted by comparing the specific capital costs for Dixie Valley $\left(450^{\circ} \mathrm{F}\right.$ resource) and Glass Mountain ( $510^{\circ} \mathrm{F}$ resource). The well flow rate at Dixie Valley is more than three times that at Glass Mountain. As a consequence, even though Glass Mountain is a significantly hotter resource than Dixie Valley, it would have a higher plant cost.

Finally, resources below $400^{\circ} \mathrm{F}$ are pumped and the loss of power due to pumping parasitics increases specific plant cost. Thus, the specific plant cost for the cooler resources $\left(<400^{\circ} \mathrm{F}\right)$ is significantly higher than that for the hotter resources $\left(2400^{\circ} \mathrm{F}\right)$.

Equipment costs for an optimal dual flash power plant at various sites are presented in Table 5-7 which presents an overview of the important capital cost elements of a dual flash plant and their interrelationships. For example, it shows that the cost of the turbine generator set comprises about $60 \%$ of the total installed equipment cost. The turbine generator cost for a plant at Coso is only about $52 \%$ of the total installed equipment cost because a plant at Coso requires a sulfur plant and a relatively expensive condenser. In a similar vein, due to high well flow rates at Salton Sea, the wellfield cost is less than $10 \%$ of the total capital cost whereas at other resources wellfield cost is 20 to $40 \%$ of the total capital cost. 


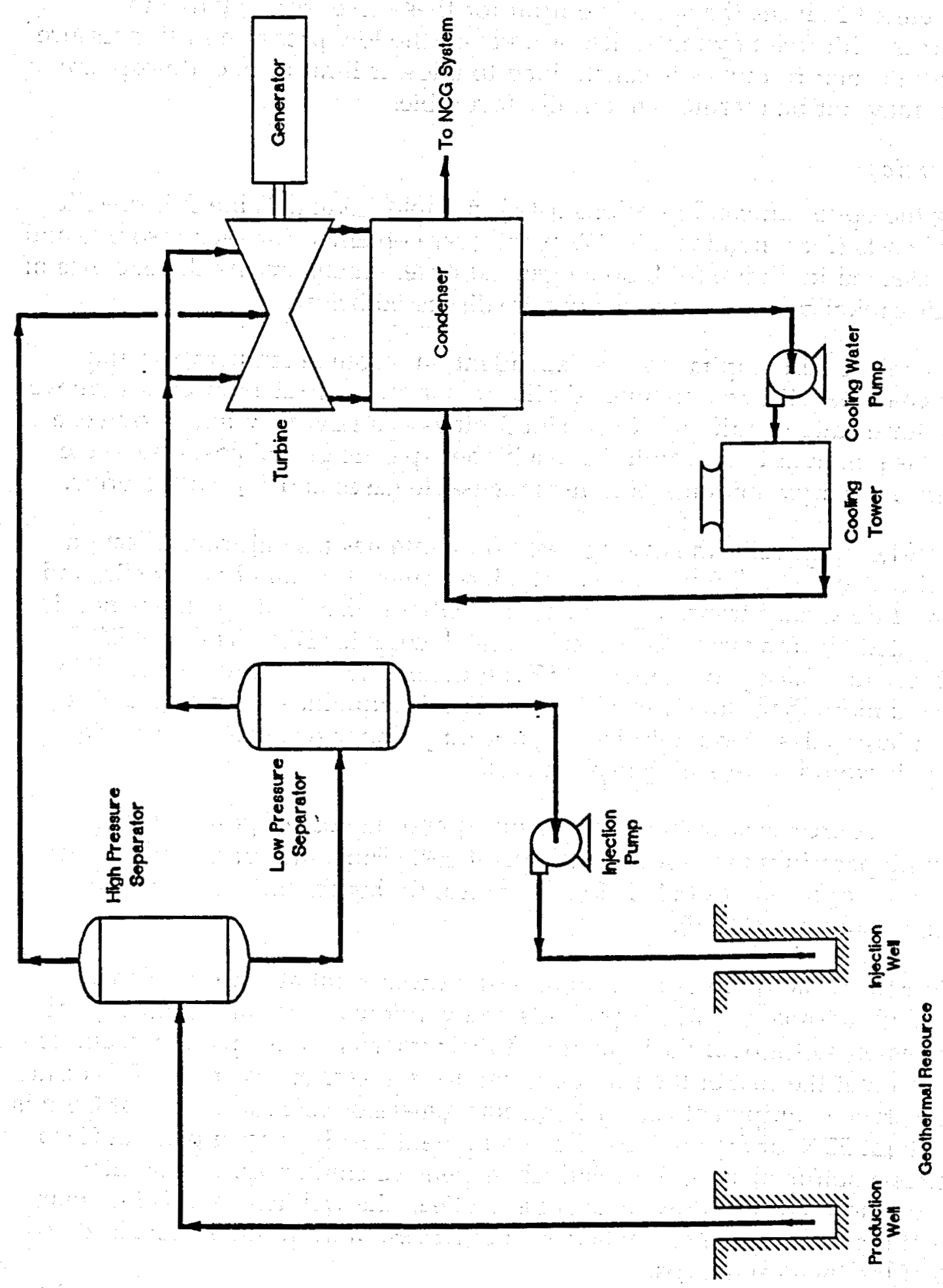

Figure 5-9

Commercial Dual Flash Cycle: Process Flow Diagram 


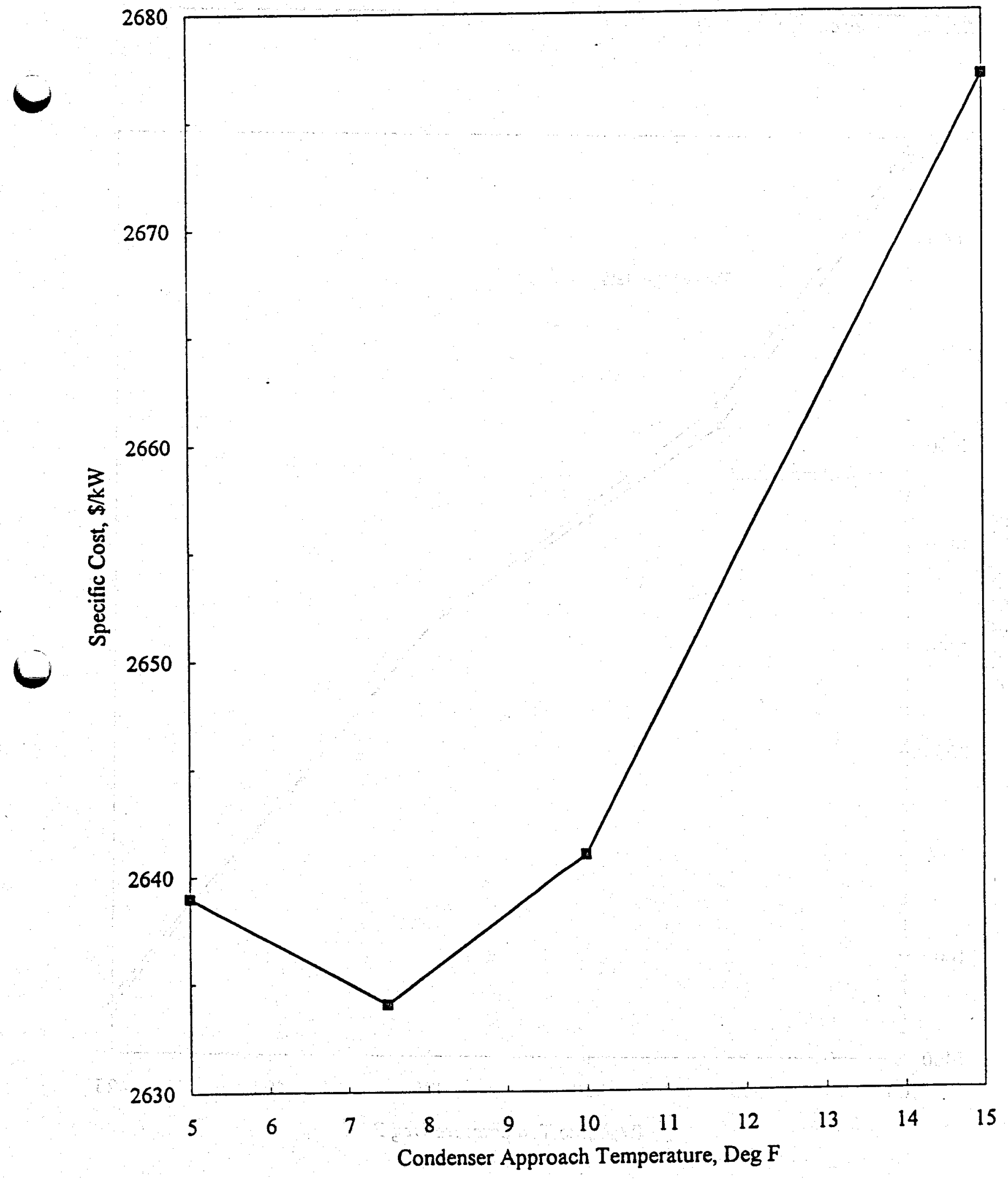

Figure 5-10

Condenser Approach Optimization 
Baseline Technologies

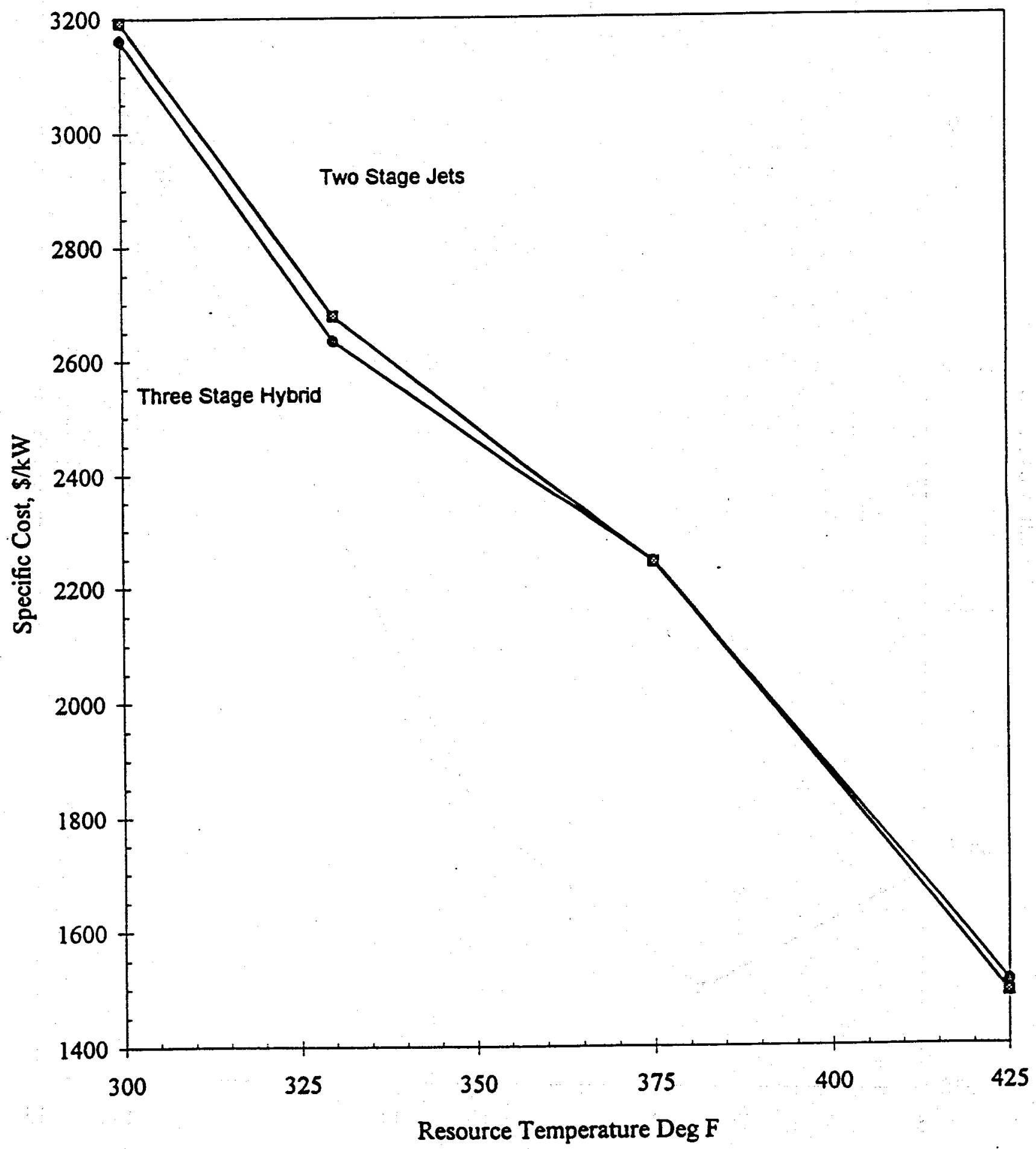

Figure 5-11

Comparison of Vacuum Systems 


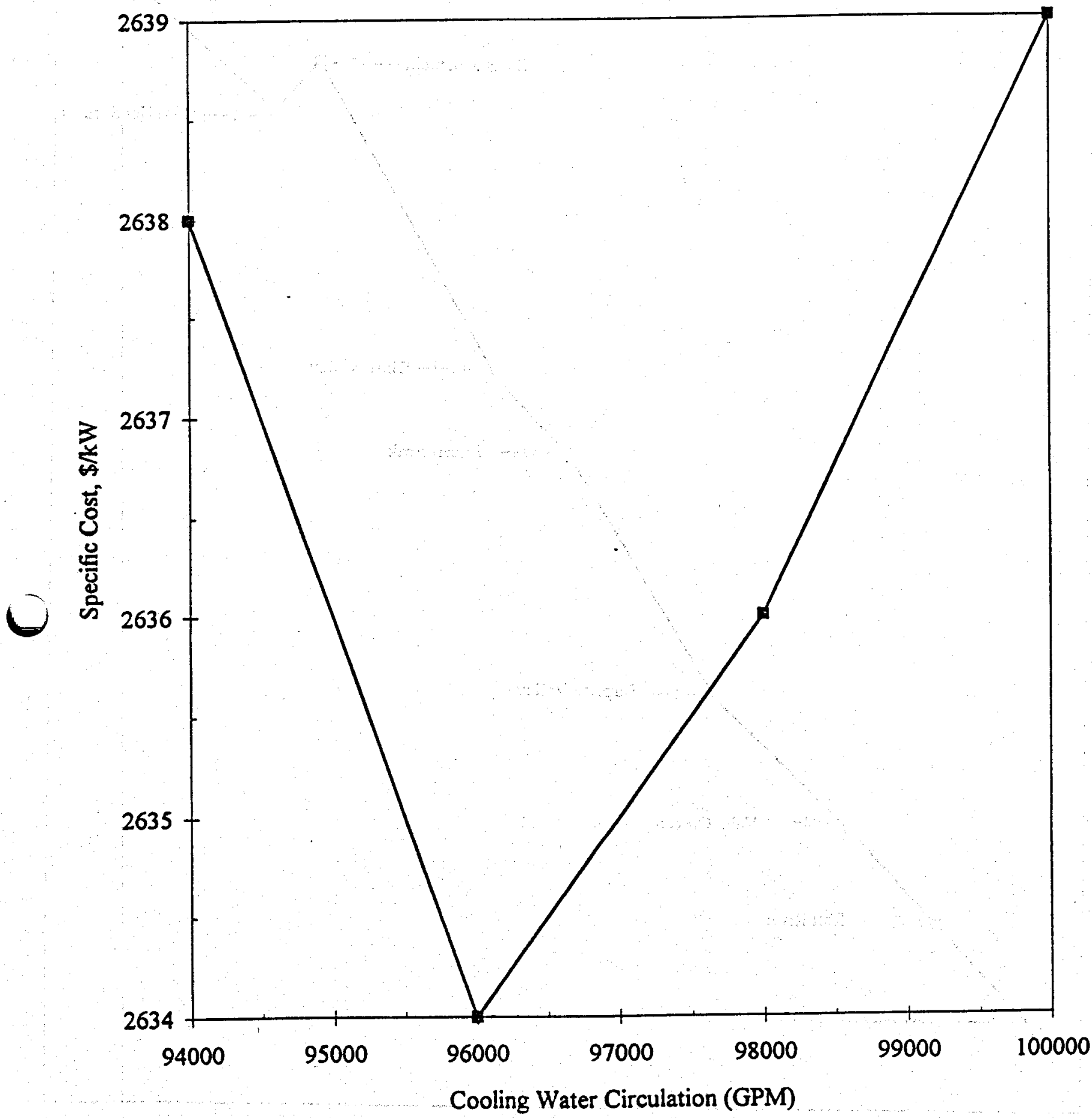

Figure 5-12

Cooling Water Circulation Optimization 


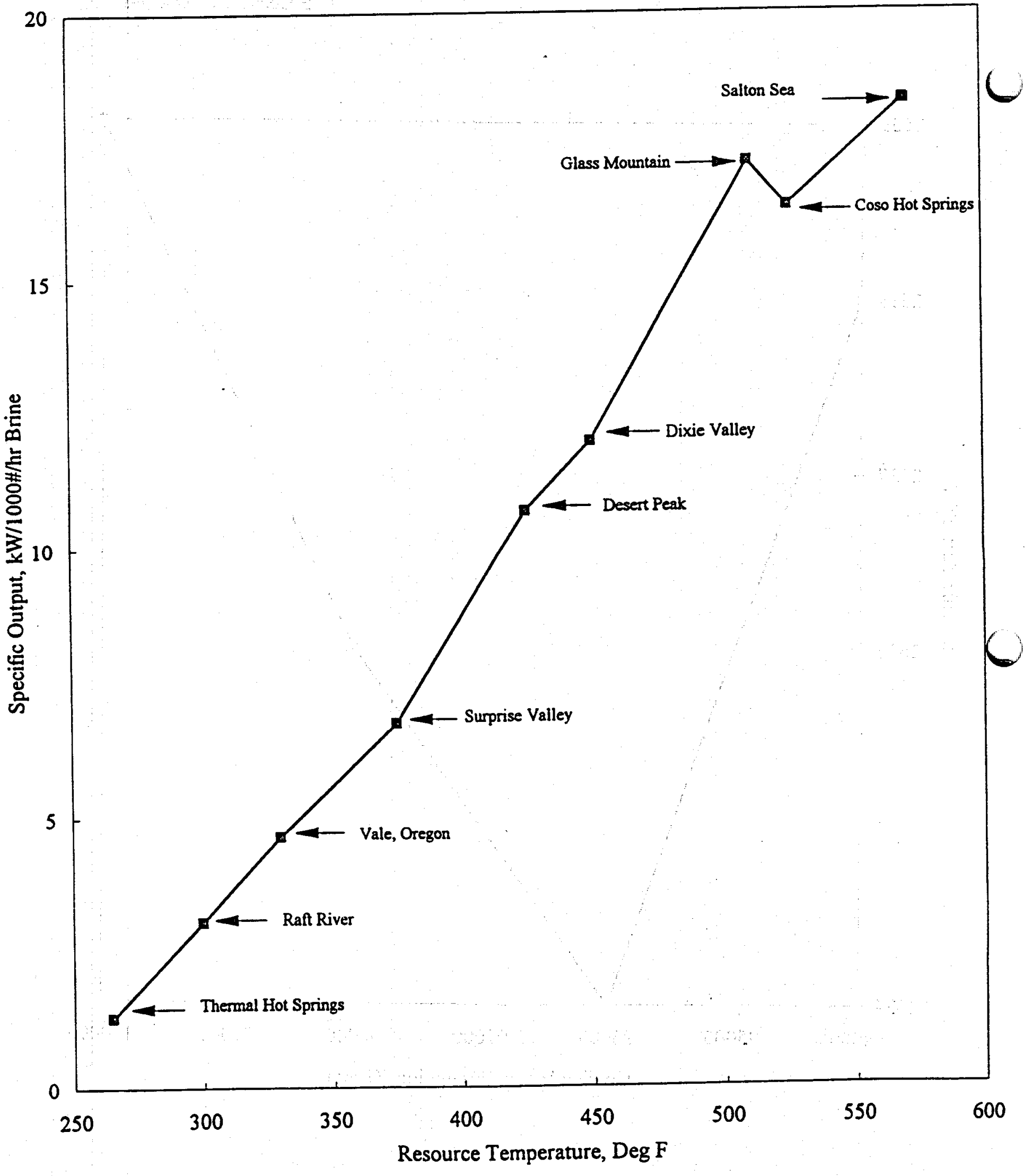

Figure 5-13

Commercial Dual Flash Cycle: Specific Output v Resource 


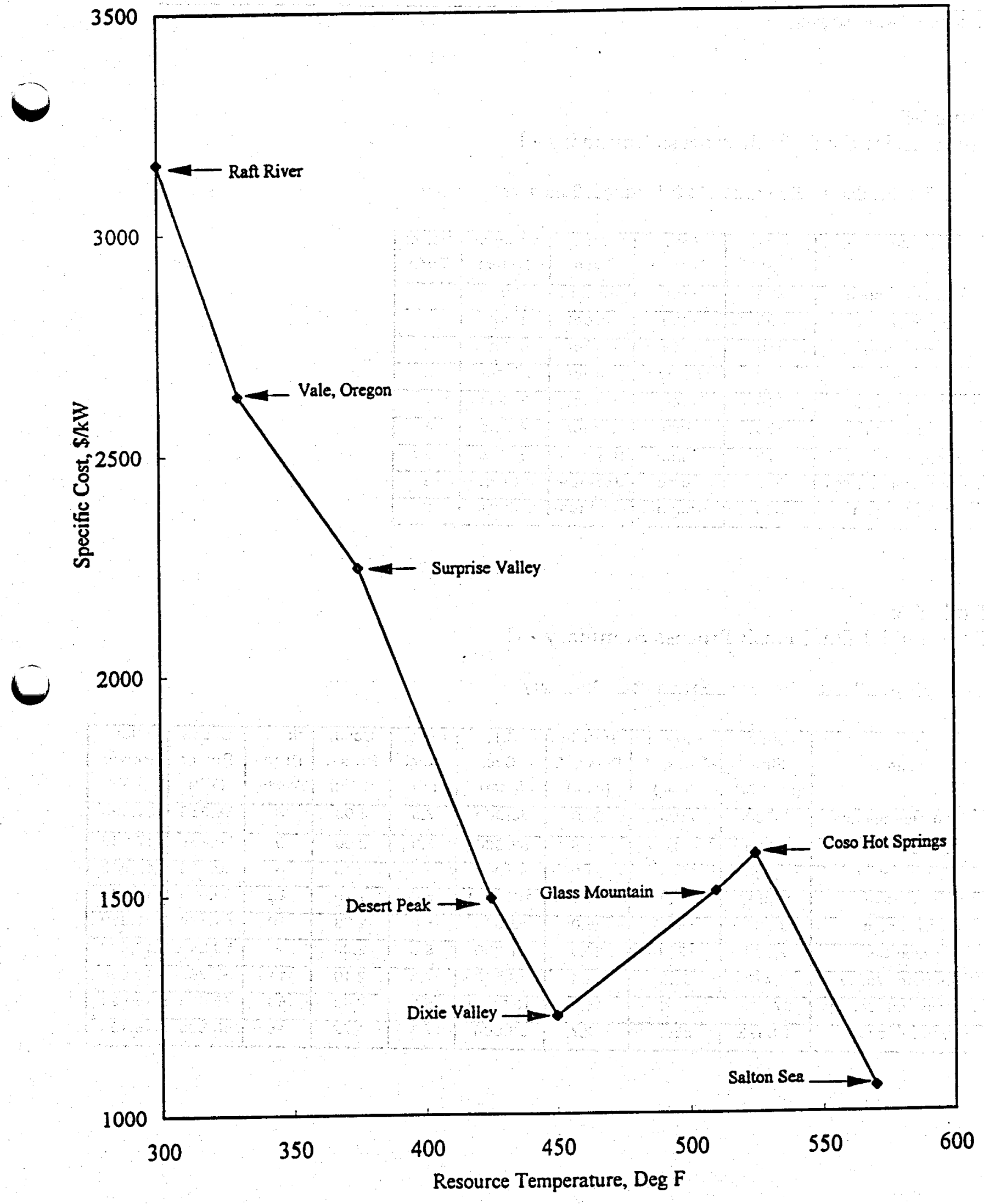

Figure 5-14

Commercial Dual Flash Cycle: Specific Capital Cost v Resource 
Table 5-5

Commercial Dual Flash Process Summary - I

Dual Flash Plant Process Modification Summary

\begin{tabular}{|c|c|c|c|c|c|}
\hline Site & $\begin{array}{c}\text { Temp } \\
(F)\end{array}$ & $\begin{array}{c}\text { Prod. } \\
\text { System }\end{array}$ & $\begin{array}{c}\text { Cond } \\
\text { Type }\end{array}$ & $\begin{array}{c}\text { Vacuum } \\
\text { System }\end{array}$ & $\begin{array}{c}\text { No. of } \\
\text { Turb }\end{array}$ \\
\hline Coso Hot Springs & 525 & Free & Surface & 3 Stage & 1 \\
\hline Desert Peak & 425 & Free & Direct & 2 Jets & 1 \\
\hline Dixie Valley & 450 & Free & Direct & 2 Jets & 1 \\
\hline Raft River & 300 & Pump & Direct & 3 Stage & 2 \\
\hline Glass Mountain & 510 & Free & Direct & 2 Jets & 1 \\
\hline Sation Sea & 570 & Free & Direct & 2 Jets & 1 \\
\hline Surprise Valley & 375 & Pump & Surface & 2 Jets & 2 \\
\hline Thermo Hot Springs & 265 & Pump & Surface & 3 Stage & 2 \\
\hline Vale, Oregon & 330 & Pump & Surface & 3 Stage & 2 \\
\hline
\end{tabular}

Table 5-6:

Commercial Dual Flash Process Summary - II

Dusl Flesh Plant Process Parameter Summary

\begin{tabular}{|c|c|c|c|c|c|c|c|c|c|}
\hline Site & $\begin{array}{c}\text { Brine } \\
\text { Flow } \\
(M \# / h r)\end{array}$ & $\begin{array}{c}\text { Turb in } \\
\text { Press, 1 } \\
\text { (psia) }\end{array}$ & $\begin{array}{c}\text { Turb in } \\
\text { Press, 2 } \\
(p s i a)\end{array}$ & $\begin{array}{c}\text { C.T. } \\
\text { Circ. } \\
(\mathrm{gpm})\end{array}$ & $\begin{array}{c}\text { Cond. } \\
\text { Aprch. } \\
(\mathrm{F})\end{array}$ & $\begin{array}{c}\text { Cond. } \\
\text { Press. } \\
(\text { ( Hg) }\end{array}$ & $\begin{array}{c}\text { No. of } \\
\text { Prod. } \\
\text { Wells }\end{array}$ & $\begin{array}{c}\text { Gross } \\
\text { Power } \\
\text { (kW) }\end{array}$ & $\begin{array}{c}\text { Net } \\
\text { Power } \\
(\mathrm{MW})\end{array}$ \\
\hline Coso Hot Springs & 3,200 & 130.0 & 24.0 & 50,000 & 7.5 & 3.03 & 8 & 56,359 & 51,995 \\
\hline Desert Peak & 4,500 & 90.0 & 21.5 & 53,000 & 5.0 & 2.00 & 9 & 50,886 & 47,946 \\
\hline Dixie Valley & 4,000 & 100.0 & 21.0 & 51,000 & 5.0 & 2.18 & 4 & 50,718 & 47,902 \\
\hline Ratt River & 15,392 & 27.0 & 12.5 & 100,000 & 5.0 & 1.79 & 22 & 60,656 & 47,023 \\
\hline Glass Mountain & 3,000 & 151.0 & 26.0 & 53,000 & 5.0 & 2.08 & 10 & 54,174 & 51,339 \\
\hline Salton Sea & 2,600 & 151.0 & 24.0 & 51,000 & 5.0 & 2.06 & 2 & 50,249 & 47,883 \\
\hline Surprise Valley & 7,473 & 51.5 & 12.4 & 79,500 & 7.5 & 2.10 & 11 & 57,765 & 49,998 \\
\hline Thermo Hot Springs & 37,903 & 20.0 & 11.9 & 124,000 & 5.0 & 2.43 & 53 & 78,325 & 49,921 \\
\hline Vale, Oregon & 10,375 & 35.4 & 12.7 & 96,000 & 7.5 & 1.72 & 15 & 58,603 & 48,159 \\
\hline
\end{tabular}


Table 5-7

Commercial Dual Flash Cycle: Major Equipment Costs

Subject: Dual Flash Geothermal

Plant Capital Costs

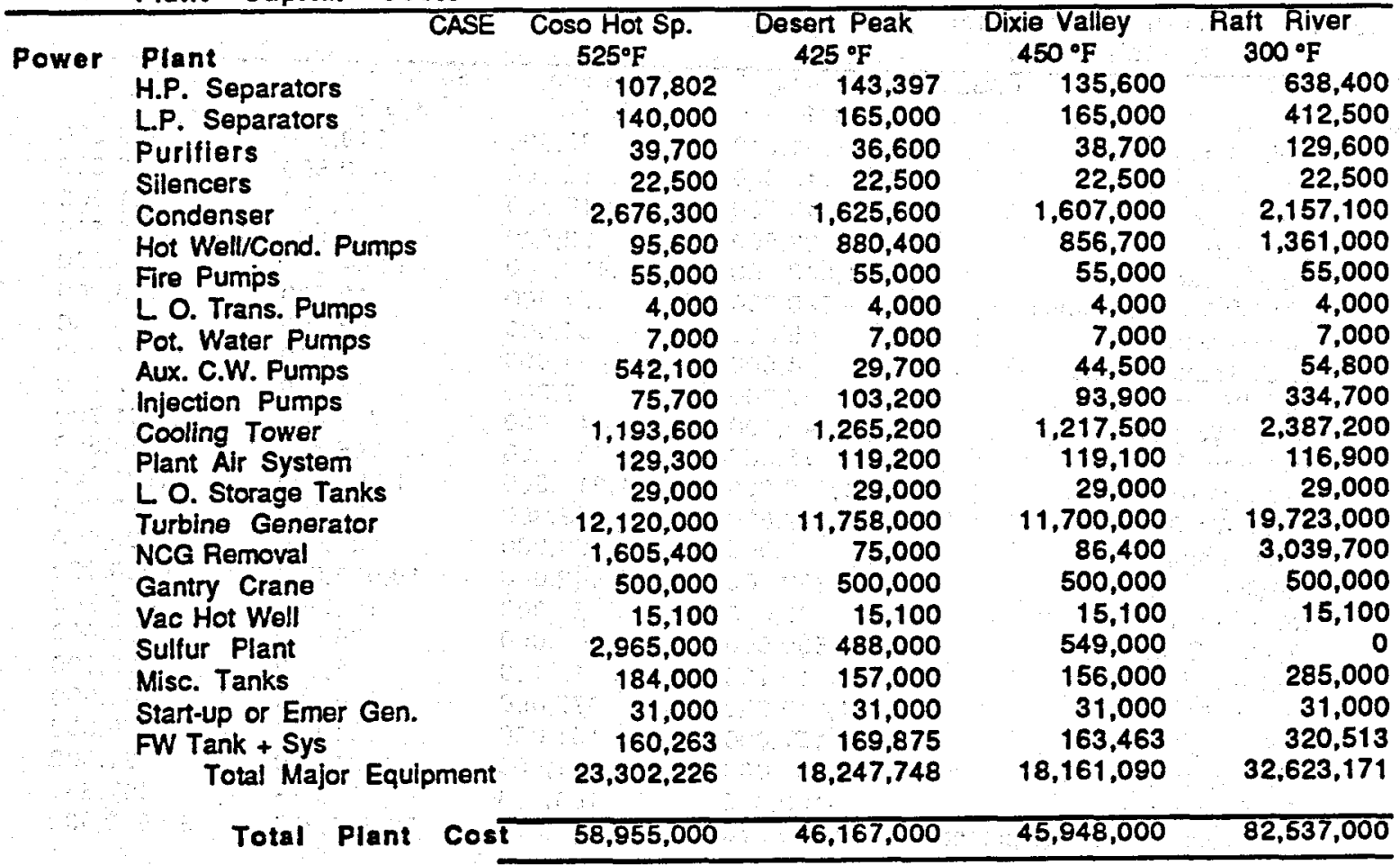

Gathering \& Inlection System

Production Pumps

Prod. Pump Aux.

Silencers

Total Major Equipment

Total

\begin{abstract}
1
\end{abstract}
Summary

Plant Equip. Cost

Total Plant Equip Cost

Gath \& Injec Equip Cost

Total Gath \& Injec Equip Cost

CASE Coso Hot Sp. 23,302,226 $58,955,000$

$\begin{array}{rr}0 & 0 \\ 0 & 0 \\ 25,000 & 25,000\end{array}$

25,000

25,000

53,000

25,000

53,000

Desert Peak
$18,247,748$
$46,167,000$

Dixie Valley

$18,161,090$

$18,161,090$
$45,948,000$

$1,540,000$

$22,000,000$
Raft River
25,000
53,000

$3,123,295$

158,400

25,000

$3,306,695$
Well

Cost

Gath \& Injec Piping Cost

Grand Total

Specific cost (\$/kW)
$82,548,000$

1,588
25,000

53,000

$1,486,000$

$23,765,060$

$71,471,060$

1,491 
Table 5-7

Commercial Dual Flash Cycle: Major Equipment Costs (Continued)

Subject: Dual Flash Geothermal
Plant Capital Costs

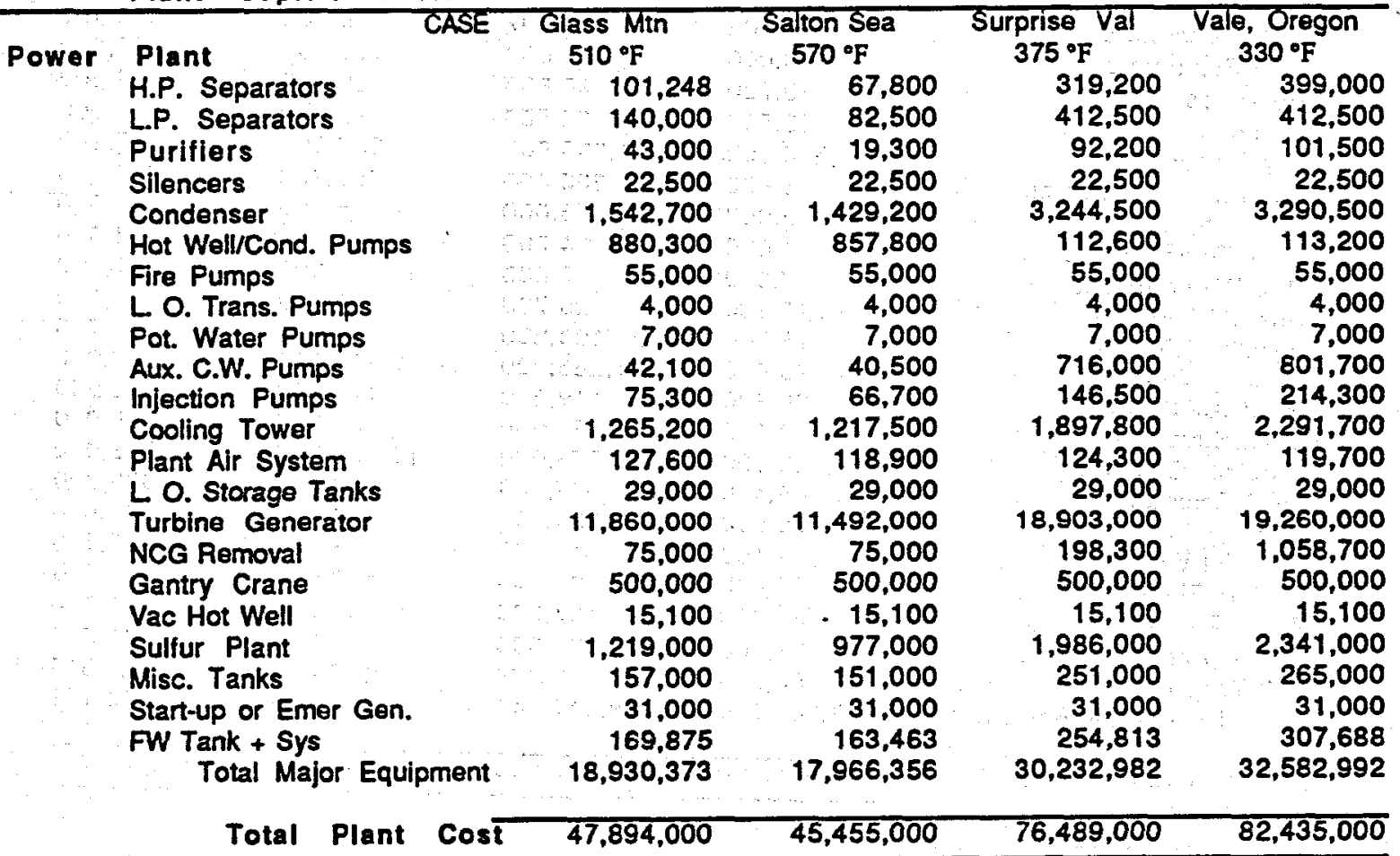

Gathering \& Injection System Production Pumps Prod. Pump Aux. Silencers

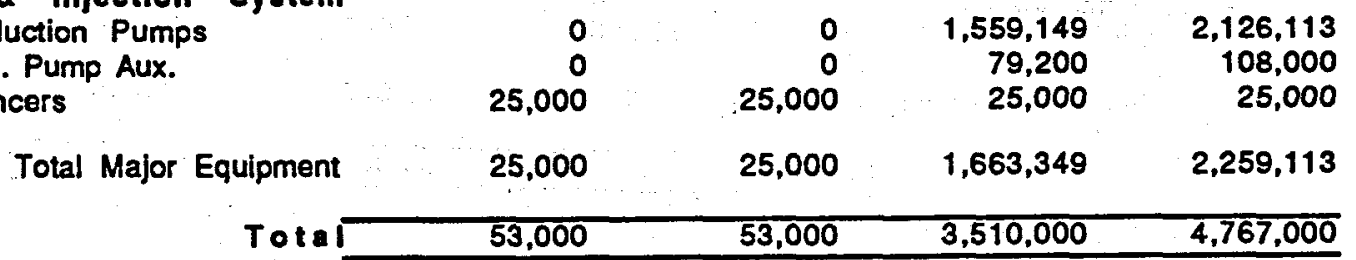

\begin{tabular}{|c|c|c|c|c|}
\hline $\begin{array}{l}\text { Plant Equip. Cost } \\
\text { Total Plant Equip Cost }\end{array}$ & $\begin{array}{r}\text { Glass Min } \\
18,930,373 \\
47,894,000\end{array}$ & $\begin{array}{r}\text { Salton Sea } \\
17,966,356 \\
45,455,000\end{array}$ & $\begin{array}{r}\text { Surprise Val } \\
30,232,982 \\
76,489,000\end{array}$ & $\begin{array}{r}\text { Vale, Oregon } \\
32,582,992 \\
82,435,000\end{array}$ \\
\hline $\begin{array}{l}\text { Gath \& Injec Equip Cost } \\
\text { Total Gath \& Injec Equip Cost }\end{array}$ & $\begin{array}{l}25,000 \\
53,000\end{array}$ & $\begin{array}{l}25,000 \\
53,000\end{array}$ & $\begin{array}{l}1,663,349 \\
3,510,000\end{array}$ & $\begin{array}{l}2,259,113 \\
4,767,000\end{array}$ \\
\hline $\begin{array}{l}\text { Gath \& Injec Piping Cost } \\
\text { Well } \\
\text { Cost }\end{array}$ & $\begin{array}{r}1,754,000 \\
27,500,000\end{array}$ & $\begin{array}{r}542,000 \\
4,500,000\end{array}$ & $\begin{array}{r}1,084,000 \\
31,000,000\end{array}$ & $\begin{array}{r}1,194,000 \\
38,470,588\end{array}$ \\
\hline $\begin{array}{c}\text { Grand Total } \\
\text { Specific cost }(\$ / k W)\end{array}$ & $\begin{array}{r}77,201,000 \\
1,504\end{array}$ & $\begin{array}{r}50,550,000 \\
1,057\end{array}$ & $\begin{array}{r}112,083,000 \\
2,242\end{array}$ & $\begin{array}{r}126,866,588 \\
2,634\end{array}$ \\
\hline
\end{tabular}




\section{Conclusions}

In conclusion, it would be instructive to compare the performance of the three baseline technologies at the various geothermal sites. Figures 5-15 and 5-16 are plots of specific output and specific capital cost, respectively, for the air-cooled commercial binary, water-cooled commercial binary, and dual flash cycles for all the geothermal sites that the cycles were developed for. Figure 5-16 shows that for resources hotter than Surprise Valley, dual flash power plants have a lower specific capital cost than binary power plants. For Surprise Valley and colder resources, binary power plants have lower specific capital costs compared to dual flash power plants. It appears, then, that binary cycle is the current technology of choice for resources colder than about $400^{\circ} \mathrm{F}$; whereas for resources hotter than $400^{\circ} \mathrm{F}$ dual flash technology is favored. 


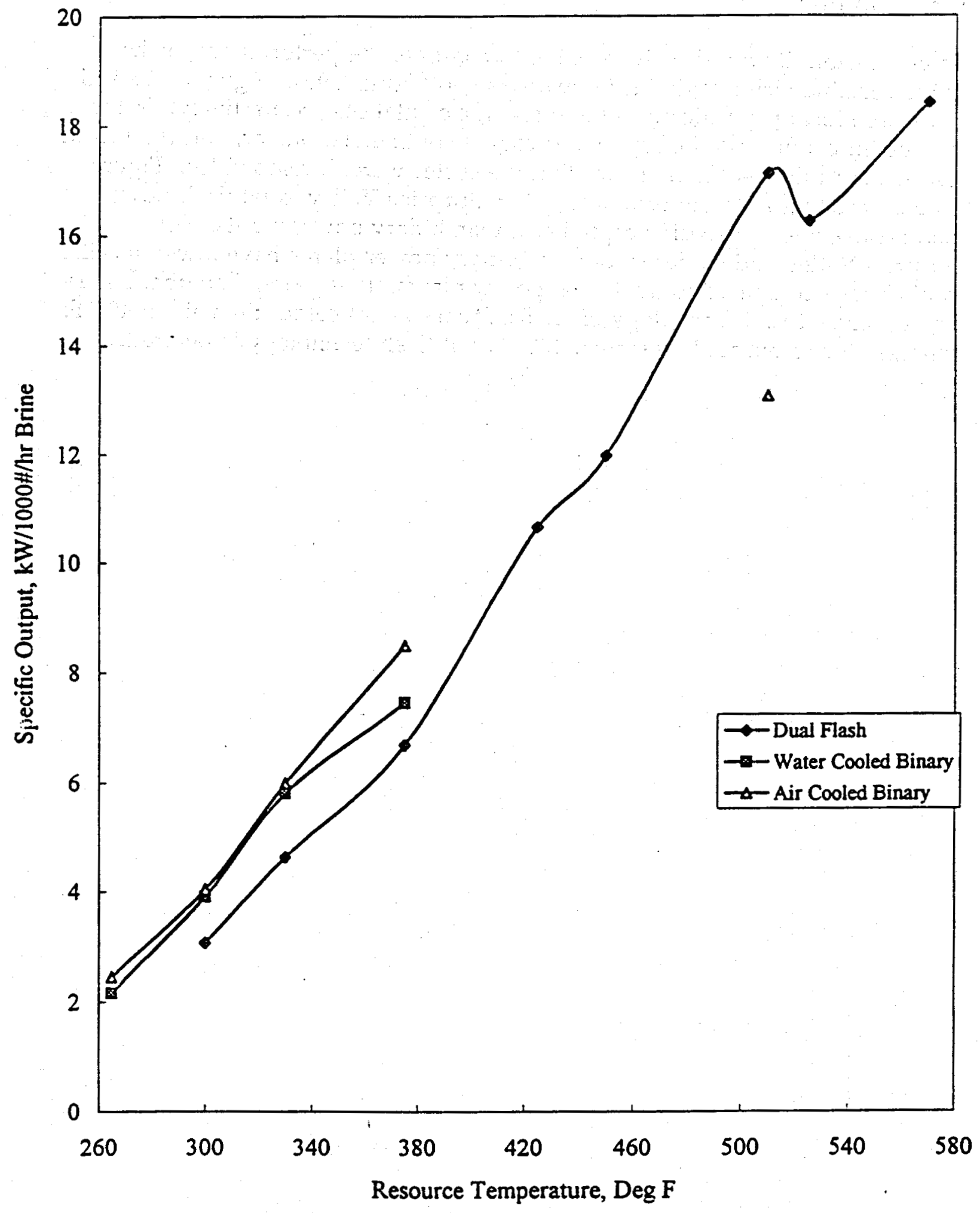

Figure 5-15
Baseline Technologies - Specific capital fobt v Resource 


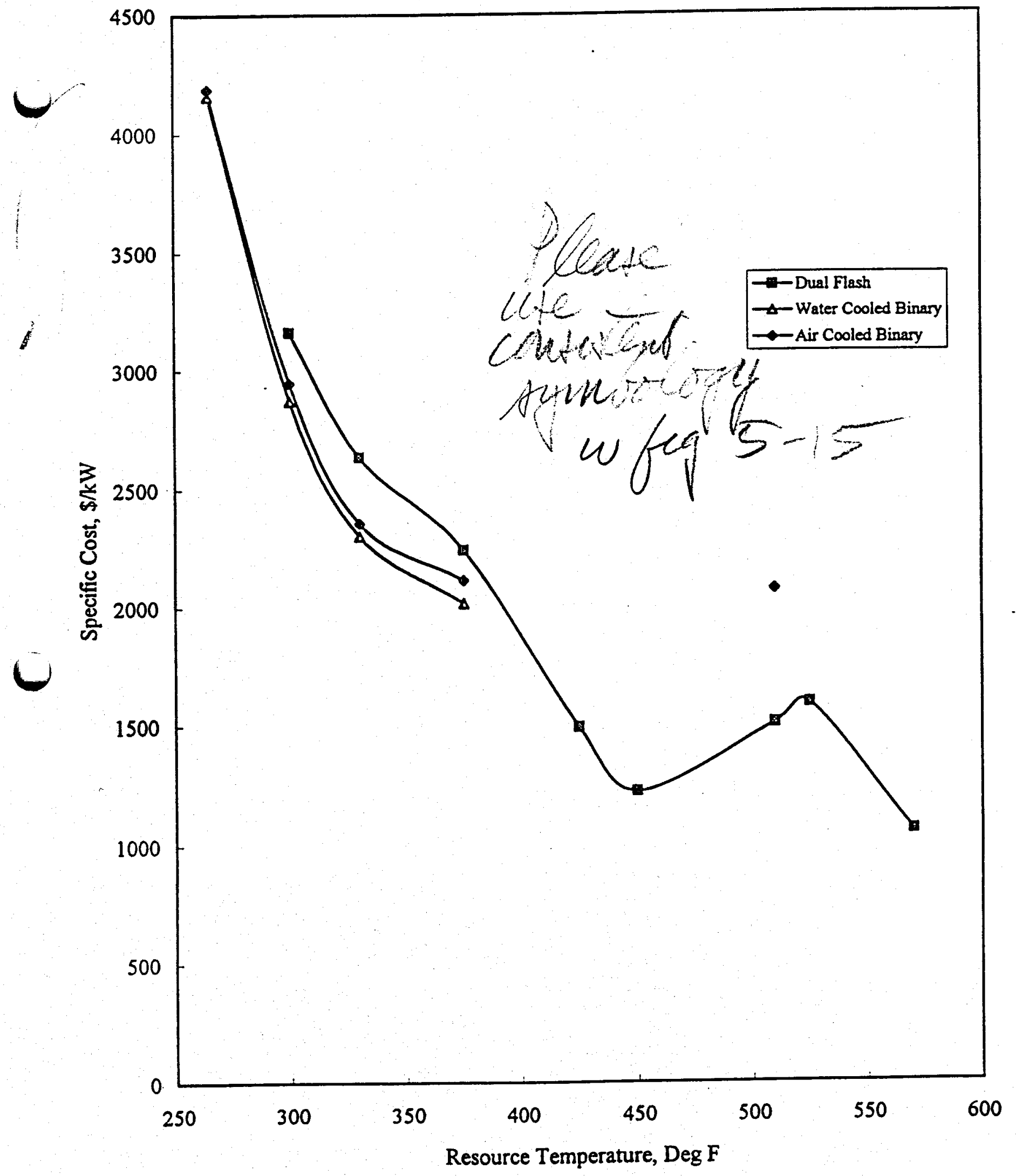

Figure 5-16

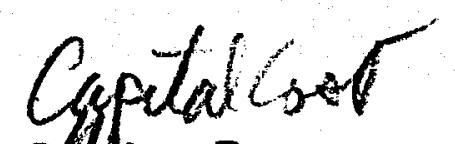

Baseline Technologies - Specific 94 pt v Resource 


\section{6}

\section{ADVANCED BINARY CYCLES}

\section{Mixed Fluid Binary: Hydrocarbon Mixtures}

\section{Introduction}

As noted earlier, both air-cooled and water-cooled commercial binary cycles were evaluated with commercial isobutane, which essentially behaves as a pure component, as the working fluid. Some prior studies have suggested that using mixtures of hydrocarbons instead of pure components in binary cycles will enhance the cycle's specific output (Demuth, 1982; Bleim and Mines, 1993). In this section of the report the evaluation of binary cycles with mixed working fluids is presented.

In binary cycles that use mixed working fluids, a non-isothermal condensing curve is obtained which enables the use of smaller air-cooled condensers compared to commercial binary cycles. As a result, mixed fluid cycles yield a lower specific capital cost than commercial binary cycles.

It is worth noting here that past studies which used mixtures of hydrocarbons as working fluids primarily focused on counterflow water-cooled binary units that assumed a $10^{\circ} \mathrm{F}$ approach at the hot end of the condenser (Id.). In the present study, mixed fluids were evaluated using crossflow air-cooled cycles in which condenser approaches of $10^{\circ} \mathrm{F}$ are not generally acheivable.

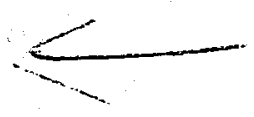

\section{Cycle Process Flow}

The mixed fluid binary cycle analyzed in this study has the same configuration as the air-cooled commercial binary cycle. Hence, the reader is referred to Section 5 for the process flow description and diagram (Figure 5-1).

\section{Performance Analysis}

\section{Description}

Mixed fluid cycles were evaluated using essentially the same methodology as that used to evaluate the air cooled commercial binary cycles. Hence, once again, the reader is referred to Section 5 . 


\section{Assumptions}

The specific and general assumptions used in the analysis of the air-cooled commercial binary cycle also apply to the mixed fluids binary cycle (refer to Section 5).

Heat transfer coefficients used to calculate the sizes and costs of the heat exchangers for the air-cooled commercial binary cycle were also used for heat exchanger sizing for the mixed fluid binary cycle. A sensitivity analysis was performed to determine the effect of a $10 \%$ reduction in heat transfer coefficients on the specific power cost. The results of the sensitivity analysis are summarized in Table 6-1. It can be seen that a $10 \%$ variation in heat transfer coefficients affects the plant cost by 1 to $3 \%$. Thus, it appears that the assumption is justified since it is unlikely that the inaccuracy in heat transfer coefficients can exceed $10 \%$, and a $10 \%$ variation in heat transfer coefficients only affects the plant cost marginally.

\section{Cost Analysis}

The cost model used for calculating plant costs for the air-cooled commercial binary cases was also used for calculating plant costs for the mixed fluids binary cycles.

\section{Results}

Table 6-2 compares the specific capital cost and specific output of the optimum mixed fluid cycle with those of the optimum air cooled commercial binary cycle. It can be observed from the table that mixed fluid cycles have a lower specific capital cost than their commercial binary counterparts even though they have a lower specific output. It appears that the lower specific output for mixed fluid cycles is offset by the lower condenser costs compared to the commercial binary cycles.

Detailed results of the evaluation of the mixed fluid cycle performance for individual sites are presented below.

\section{Surprise Valley, California}

Past studies (Bleim and Mines, 1993) have shown that $350-400^{\circ} \mathrm{F}$ resource temperatures are well suited to mixed fluid cycles, and Surprise Valley with a resource temperature of $375^{\circ} \mathrm{F}$ falls in that range. Mixed fluids cycles at Surprise Valley were evaluated for the following working fluid mixtures:

- 80 mole \% iC4/20 mole \% iC5 ( $80 / 20$ mixture)

- $\quad 94 \mathrm{wt} \% \mathrm{iC} 4 / 6 \mathrm{wt} \% \mathrm{iC7}(94 / 6$ mixture), the mixture reported in literature. (Bleim \& Mines, 1993) 
Table 6-3 summarizes the performance of the mixed fluid cycles at Surprise Valley. It can be inferred from the table that the $94 / 6$ mixture yields the minimum capital cost power plant whereas the $80 / 20 \mathrm{iC} 5$ mixture yields the maximum specific output power plants. The same conclusion can be drawn from Figure 6-1 and Figure 6-2 which are plots of specific output and specific capital cost, respectively.

In the course of evaluating mixed fluids cycles at Surprise Valley, the issue of optimum condenser approach and pinch was investigated. A number of mixed fluids cycles were simulated with the $94 / 6$ mixture at 600 psia turbine inlet pressure and with varying cold end approaches to determine the optimum cold end pinch. The results of this optimization are plotted in Figure 6-3 which shows that a cold end approach of about $30^{\circ} \mathrm{F}$ is optimum for the $94 / 6$ mixture. Thus, the $34^{\circ} \mathrm{F}$ cold end approach used in this study, so as to better compare results with the commercial isobutane cases, is optimal or near optimal.

As noted earlier, a $10^{\circ} \mathrm{F}$ cold end approach has been used in previous studies on counterflow water-cooled mixed fluid binary cycles (Demuth 1982, Bleim and Mines, 1993). For the Surprise Valley resource, a $10^{\circ} \mathrm{F}$ cold end approach leads to a temperature cross in the air-cooled condenser, and a feasible air cooler design cannot be obtained. Since a water-cooled condenser operating in pure counterflow will have a significantly different thermal performance than an air-cooled condenser which is a crossflowexchangers, there will be a difference between our results and those of Bleim and Mines.

\section{Vale, Oregon}

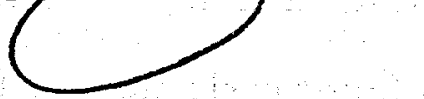

Mixed fluid cycles at Vale were only evaluated for the $94 / 6$ mixtures, and Table 6-4 summarizes cycle performance at Vale for the $94 / 6$ mixtures. Using the data in Table 6-4, specific output and specific capital cost are plotted in Figure 6-4 and Figure 6-5, respectively. Specific capital costs for the commercial binary cycle are also plotted on Figure 6-5, and it can be seen that specific capital cost for the $94 / 6$ mixture cycle is about $6 \%$ less than the optimum commercial binary cycle.

Raft River, Idaho

Three mixtures were used to evaluate the mixed fluids cycles at Raft River:

- $94 \%$ isobutane/6\% heptane mixture (94/6 mixture)

- $6 \%$ propane $/ 88 \%$ isobutane $/ 6 \%$ heptane $(6 / 88 / 6$ mixture)

- $\quad 12 \%$ propane $/ 82 \%$ isobutane $/ 6 \%$ heptane ( $12 / 82 / 6$ mixture)

A summary of the results for the three mixtures is presented in Table 6-5 which shows that the $94 / 6$ mixture yields the optimum performance for the 
mixed fluids binary cycle at Raft River. Figure 6-6 and 6-7 are plots of specific output and specific capital cost, respectively, for the mixed fluids cycles and the commercial binary cycle. It can be observed from these figures that although the specific output of the mixed fluids binary cycle is less than that of the commercial binary cycle, the mixed fluids cycle has a lower capital cost than the commercial binary cycle.

\section{Thermo Hot Springs, Utah}

The effectiveness of the mixed fluids cycle at Thermo Hot Springs was studied using four mixtures as working fluids:

- $6 \%$ propane $/ 94 \%$ isobutane $(6 / 94$ mixture)

- $6 \%$ propane $/ 88 \%$ isobutane $/ 6 \%$ heptane $(6 / 88 / 6$ mixture)

- $12 \%$ propane $/ 82 \%$ isobutane $/ 6 \%$ heptane (12/82/6 mixture)

- $94 \%$ isobutane $/ 6 \%$ heptane ( $94 / 6$ mixture)

Based on previous studies (Bleim 1993) which have indicated that a closer condenser cold end pinch might improve performance for relatively cold resources, mixed fluids cycles with $94 / 6$ mixtures were evaluated for two condensing temperatures: $74^{\circ} \mathrm{F}$ and $85^{\circ} \mathrm{F}$. The results of this evaluation, which are plotted in Figure 6-8, show that cycle performance is better at $74^{\circ} \mathrm{F}$ condensing temperatures than at $85^{\circ} \mathrm{F}$ condensing temperatures.

Results of the mixed fluids cycle analysis for Thermo Hot Springs are summarized in Table 6-6. Figures 6-9 and 6-10 plot the specific output and specific capital cost, respectively. Table 6-6 shows that, of the mixtures considered in this study, the $94 \%$ isobutane/6\% heptane mixture yields the optimum performance for the mixed fluid binary cycle. 
Table 6-1

Effect of Varying Heat Transfer Coefficient on Specific Plant Cost

\begin{tabular}{|c|l|c|c|c|}
\hline No. & \multicolumn{1}{|c|}{ Case } & $\begin{array}{c}\% \\
\text { Difference }\end{array}$ & $\begin{array}{c}\text { Specific Cost, } \\
\text { Best Cycle } \\
(\$ / \mathrm{kW})\end{array}$ & $\begin{array}{c}\text { Specific cost, 90\% } \\
\mathbf{U} \\
(\$ / \mathrm{kW})\end{array}$ \\
\hline 1 & Surprise Valley & 2.80 & 1859 & 1911 \\
\hline 2 & Vail & 3.07 & 2184 & 2251 \\
\hline 3 & Raft River & 1.03 & 2701 & 2774 \\
\hline 4 & $\begin{array}{l}\text { Thermo Hot } \\
\text { Springs }\end{array}$ & 2.86 & 3919 & 4031 \\
\hline
\end{tabular}

Table 6-2

Comparison of Mixed Fluid Cycle with Commercial Binary Cycle

\begin{tabular}{|c|c|c|c|c|}
\hline \multirow[t]{2}{*}{ Resource } & \multicolumn{2}{|c|}{$\begin{array}{l}\text { Specific Power Output } \\
\text { (kW/1000 Lb/hr brine) }\end{array}$} & \multicolumn{2}{|c|}{$\begin{array}{c}\text { Specific Plant Cost } \\
(\$ / \mathrm{kW})\end{array}$} \\
\hline & $\begin{array}{l}\text { Commercial } \\
\text { Binary }\end{array}$ & Mixed Fluid & $\begin{array}{l}\text { Commercial } \\
\text { Binary }\end{array}$ & Mixed Fluid \\
\hline Vail, Oregon & 5.99 & 5.26 & 2356 & 2184 \\
\hline Surprise Valley & 8.49 & 7.55 & 2115 & 1859 \\
\hline Raft River & 4.04 & 3.52 & 2945 & 2701 \\
\hline $\begin{array}{l}\text { Thermo Hot } \\
\text { Springs }\end{array}$ & 2.44 & 2.18 & 4188 & 3919 \\
\hline
\end{tabular}


Table 6-3

Surprise Valley Mixed Fluids Case Summary

\begin{tabular}{|c|c|c|c|c|c|}
\hline Case & $\begin{array}{l}\text { Well Cost } \\
\$ 1000\end{array}$ & $\begin{array}{c}\text { Installed } \\
\text { Condenser } \\
\text { Cost } \\
\$ 100\end{array}$ & $\begin{array}{l}\text { Brine Flow } \\
1000 \mathrm{lb} / \mathrm{hr}\end{array}$ & $\begin{array}{c}\text { Specific } \\
\text { Output } \\
1000 \text { lb brine }\end{array}$ & $\begin{array}{c}\text { Specific } \\
\text { Capital Cost } \\
\$ / \mathrm{kW}\end{array}$ \\
\hline $80 \% \mathrm{Mol} \mathrm{iC4:}$ & & & & & -. \\
\hline 500 PSIA & 26,250 & 23,224 & 6,661 & 7.51 & 1,918 \\
\hline 600 PSIA & 26,250 & 22,398 & 6,461 & 7.74 & 1,932 \\
\hline 700 PSIA & 26,250 & 21,721 & 6,291 & 7.95 & 1,950 \\
\hline 850 PSIA & 24,375 & 20,664 & 6,038 & 8.28 & 2,007 \\
\hline 94 iC4/6 C7: & & & & & \\
\hline 500 PSIA & 31,000 & 16,338 & 7,056 & 7.09 & 1,895 \\
\hline 600 PSIA & 31,000 & 15,995 & 6,914 & 7.23 & 1,916 \\
\hline 700 PSIA & 27,500 & 15,242 & 6,620 & 7.55 & 1,859 \\
\hline 850 PSIA & 27,500 & 14,698 & 6,358 & 7.86 & 1,912 \\
\hline
\end{tabular}

Table 6-4

Vale Mixed Fluids Case Summary

\begin{tabular}{|c|c|c|c|c|c|}
\hline Case & $\begin{array}{c}\text { Well } \\
\text { Cost } \\
\$ 1000\end{array}$ & $\begin{array}{c}\text { Installed } \\
\text { Condenser } \\
\text { Cost } \\
\$ 1000\end{array}$ & $\begin{array}{c}\text { Brine Flow } \\
1000 \mathrm{lb} / \mathrm{hr}\end{array}$ & $\begin{array}{c}\text { Specific } \\
\text { Output } \\
\mathrm{kWh} / 1000 \mathrm{lb}\end{array}$ & $\begin{array}{c}\text { Specific } \\
\text { Cost } \\
\$ / \mathrm{kW}\end{array}$ \\
\hline 300 PSIA & 40,235 & 21,582 & 11,056 & 4.52 & 2,309 \\
400 PSIA & 36,971 & 18,440 & 9,761 & 5.12 & 2,245 \\
475 PSIA & 35,206 & 17,212 & 9,510 & 5.26 & 2,184 \\
525 PSIA & 35,206 & 16,905 & 9,454 & 5.29 & 2,189 \\
\hline
\end{tabular}


Table 6-5

Raft River Mixed Fluids Case Summary

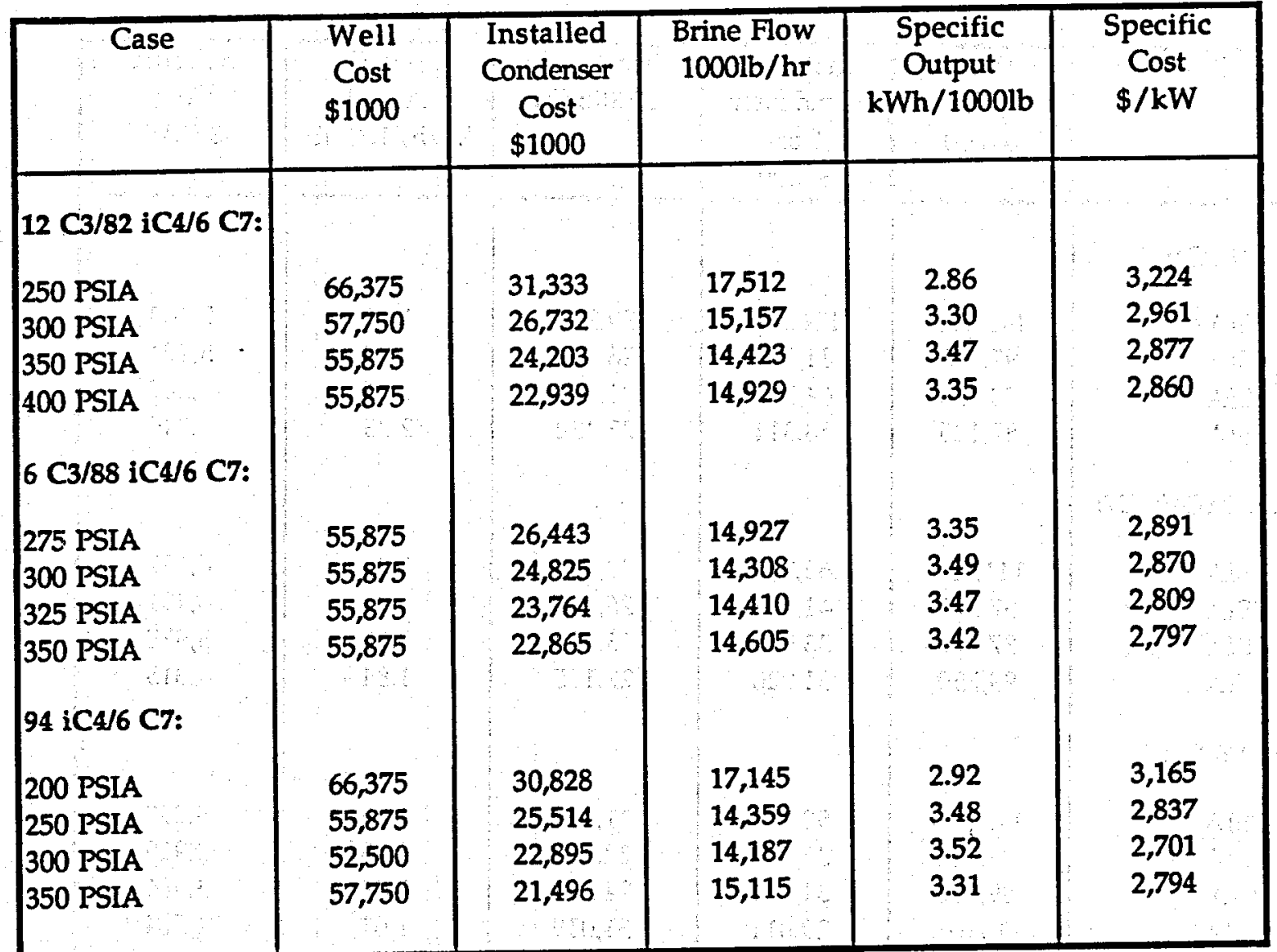


Advanced Binary Cycles

Table 6-6

Thermo Hot Springs Mixed Fluids Case Summary

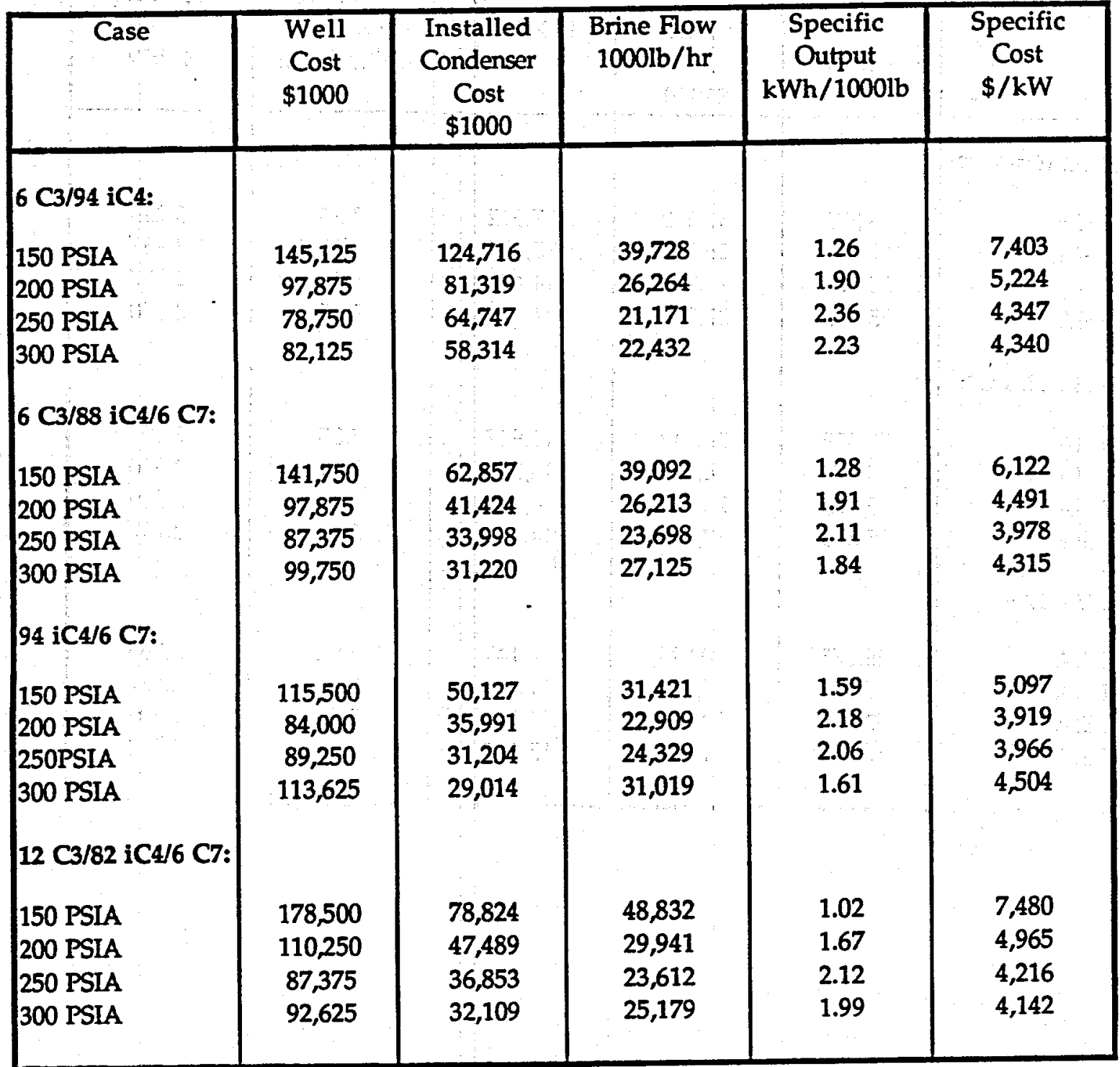


Table 6-7

Mixed Fluids Equipment Cost Summary

\begin{tabular}{|c|c|c|c|c|}
\hline & $\begin{array}{c}\text { Thermal } \\
\text { Hot Springs }\end{array}$ & $\begin{array}{l}\text { Raft } \\
\text { River }\end{array}$ & Vale & $\begin{array}{l}\text { Surprise } \\
\text { Valley }\end{array}$ \\
\hline Accumulator & 351,283 & 285,129 & 258,751 & 231,851 \\
\hline Brine/HC Preheater & $2,190,155$ & $2,438,370$ & $3,930,875$ & $2,591,049$ \\
\hline Brine/HC Vaporizer & $2,327,309$ & $1,015,146$ & 777,293 & $1,245,670$ \\
\hline Air Condenser & $11,609,932$ & $7,734,853$ & $6,082,105$ & $5,249,391$ \\
\hline Turbine Generator Set & $12,790,881$ & $11,786,609$ & $11,558,847$ & $11,809,938$ \\
\hline I-C4 Pump & 794,720 & 833,873 & $1,019,689$ & $1,352,814$ \\
\hline Injection Pumps & 278,219 & 183,531 & 122,804 & 93,774 \\
\hline Well Pumps & $5,191,863$ & $3,113,084$ & $1,918,043$ & $1,351,387$ \\
\hline Construction, Direct \& Indirect Cost & $74,622,163$ & $53,685,569$ & $46,973,191$ & $43,066,572$ \\
\hline Production Well Drilling & $60,000,000$ & $37,500,000$ & $24,705,882$ & $20,000,000$ \\
\hline Injection Well Drilling & $24,000,000$ & $15,000,000$ & $10,500,000$ & $7,500,000$ \\
\hline Gathering System & $1,817,000$ & $1,457,000$ & $1,333,187$ & $1,104,000$ \\
\hline Estimated Total Facility Cost & $195,973,525$ & $135,033,165$ & $109,180,667$ & $95,596,446$ \\
\hline Total Equipment & $35,534,362$ & $27,390,596$ & $25,668,409$ & $23,925,874$ \\
\hline Multiplier & $\begin{array}{r}3.10 \\
110,156,525\end{array}$ & $\begin{array}{r}2.96 \\
81,076,165\end{array}$ & $\begin{array}{r}2.83 \\
72,641,597\end{array}$ & $\begin{array}{r}2.80 \\
66,992,446\end{array}$ \\
\hline & & & & \\
\hline
\end{tabular}




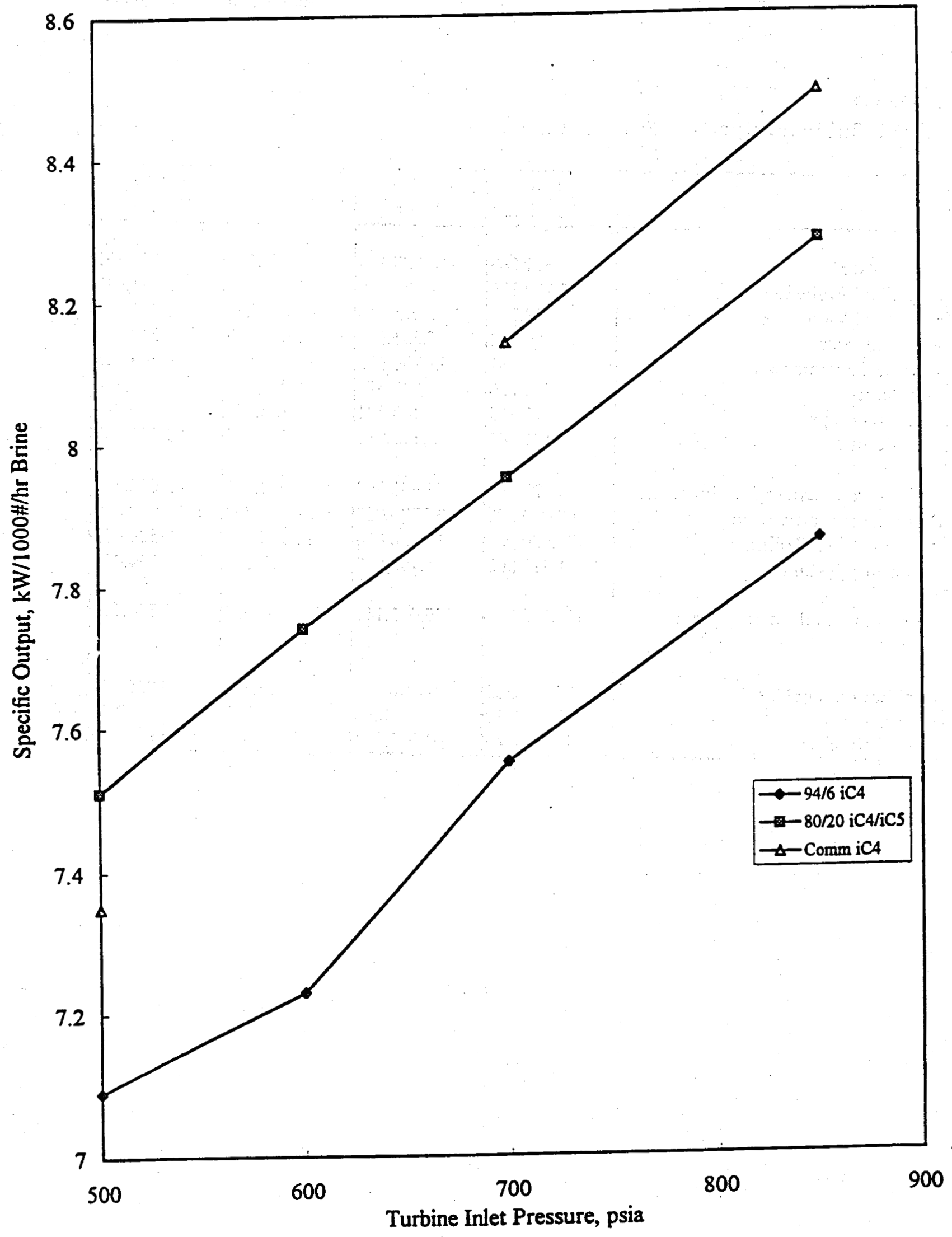

Figure 6-1

Mixed Fluids Specific Output Curves (SV) 


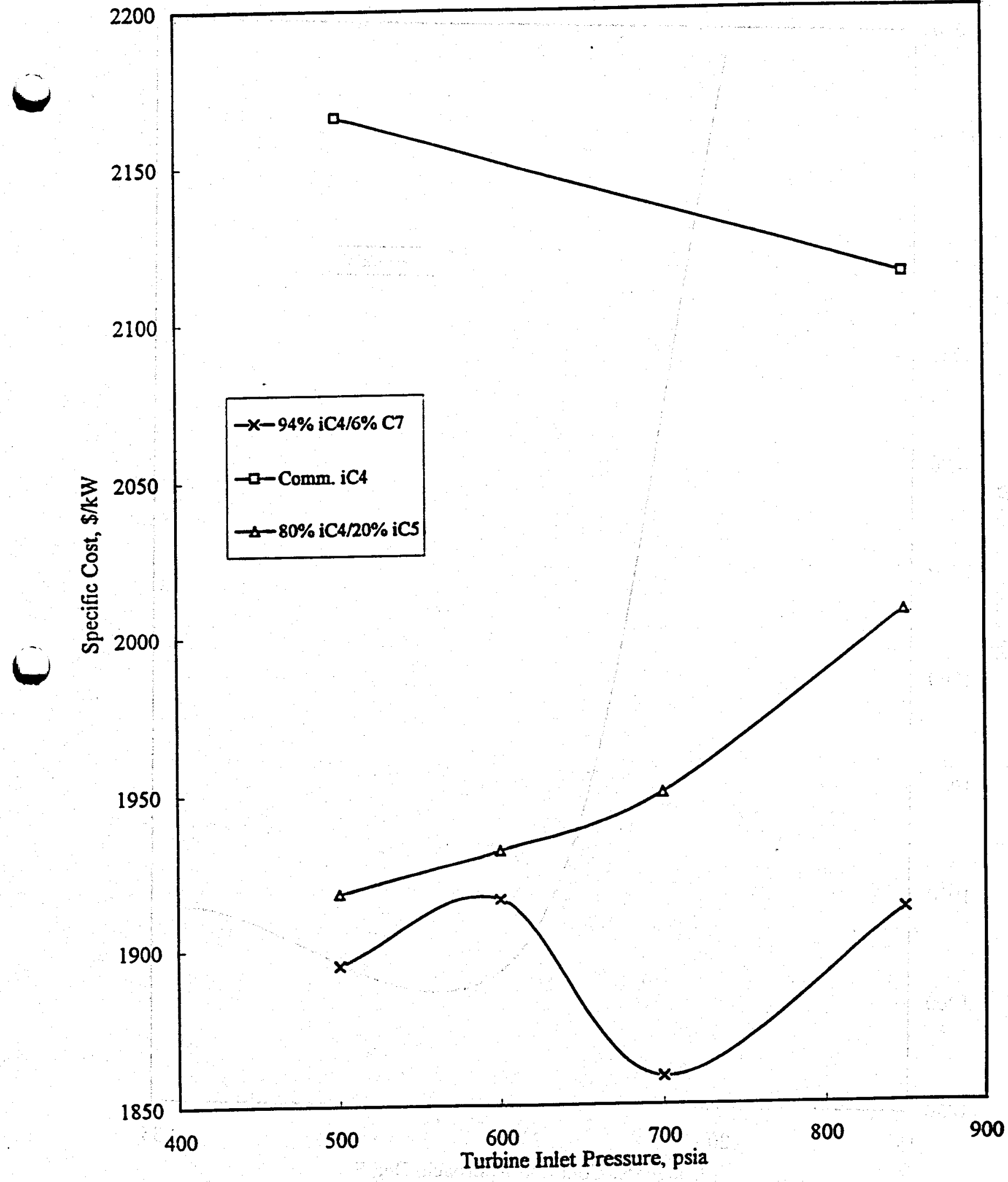

Figure 6-2

Mixed Fluids Specific Capital Cost Curves Curves (SV) 


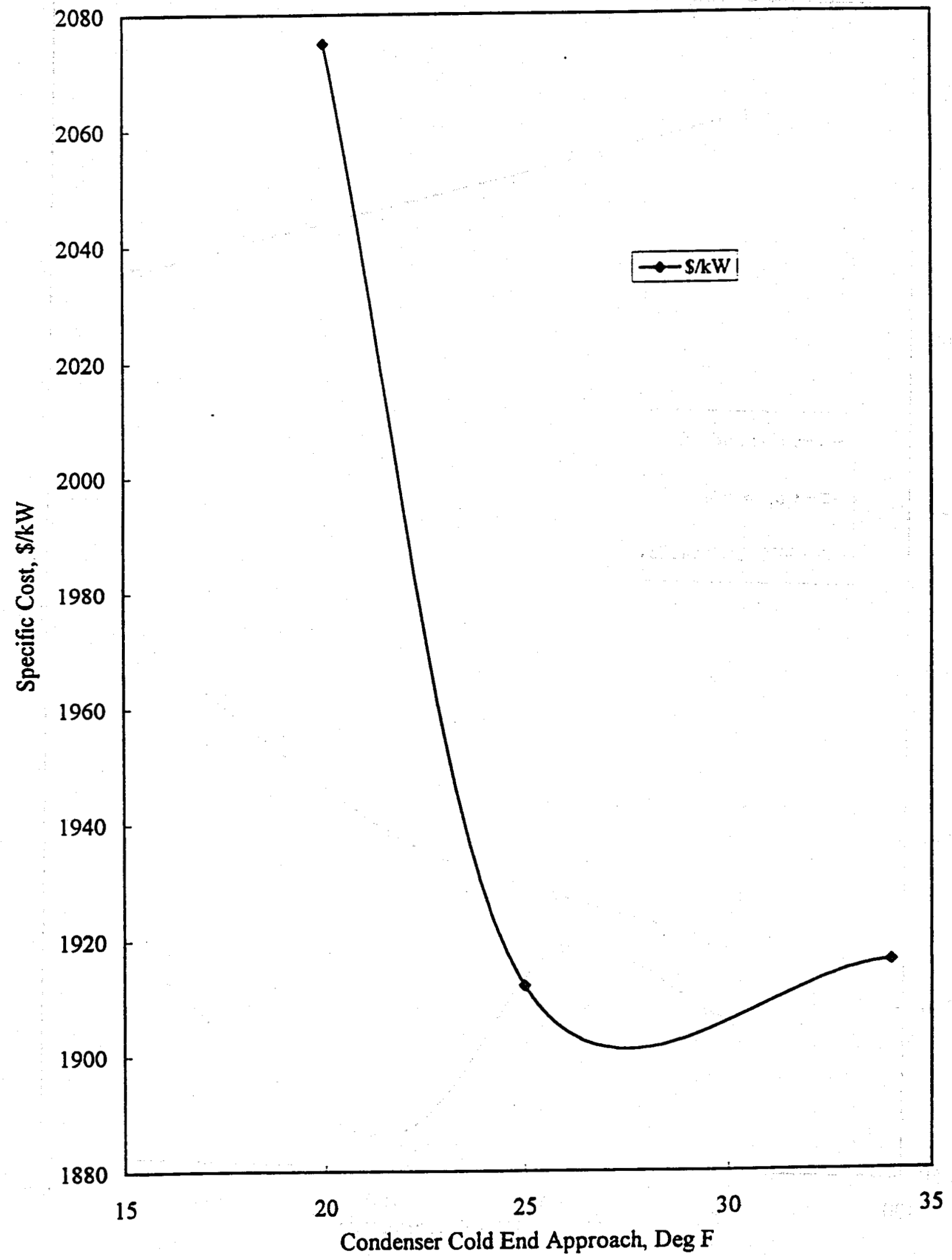

Figure 6-3

Specific Capital Cost v. Cold End Pinch 

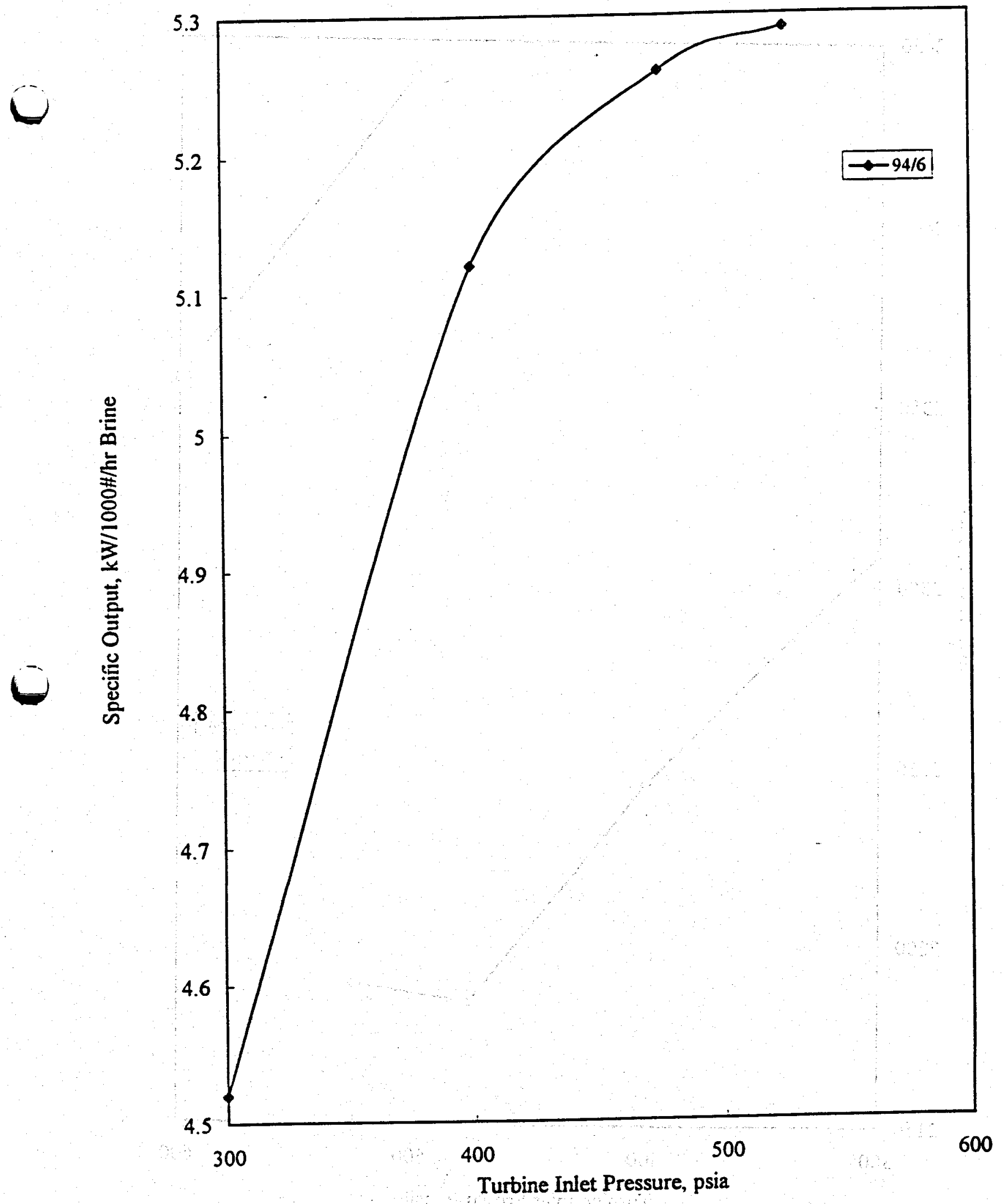

Figure 6-4

Mixed Fluids Specific Output Cúrves (VO) 

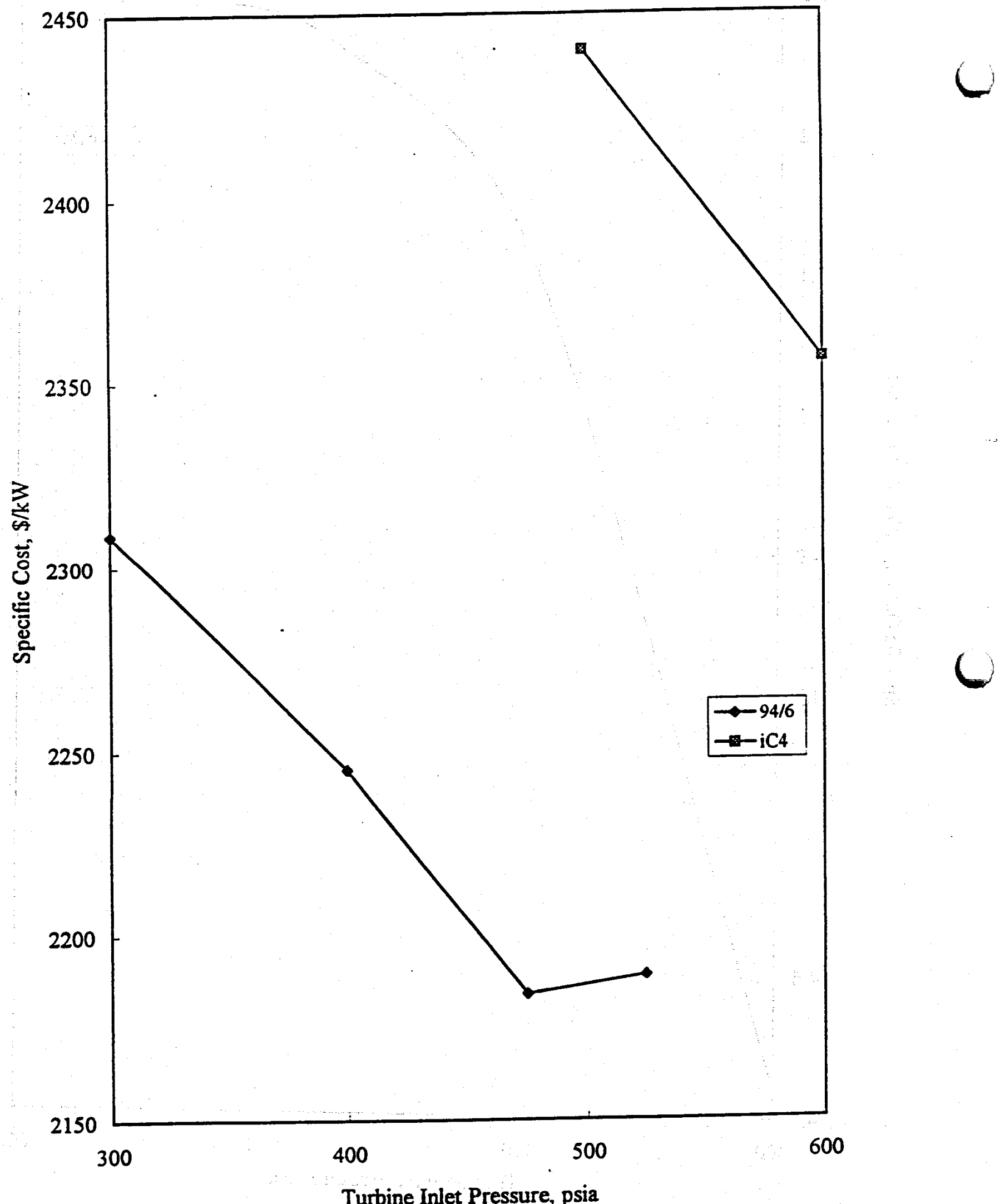

Figure 6-5

Mixed Fluids Specific Capital Cost Curves Curves (VO)

6-14 


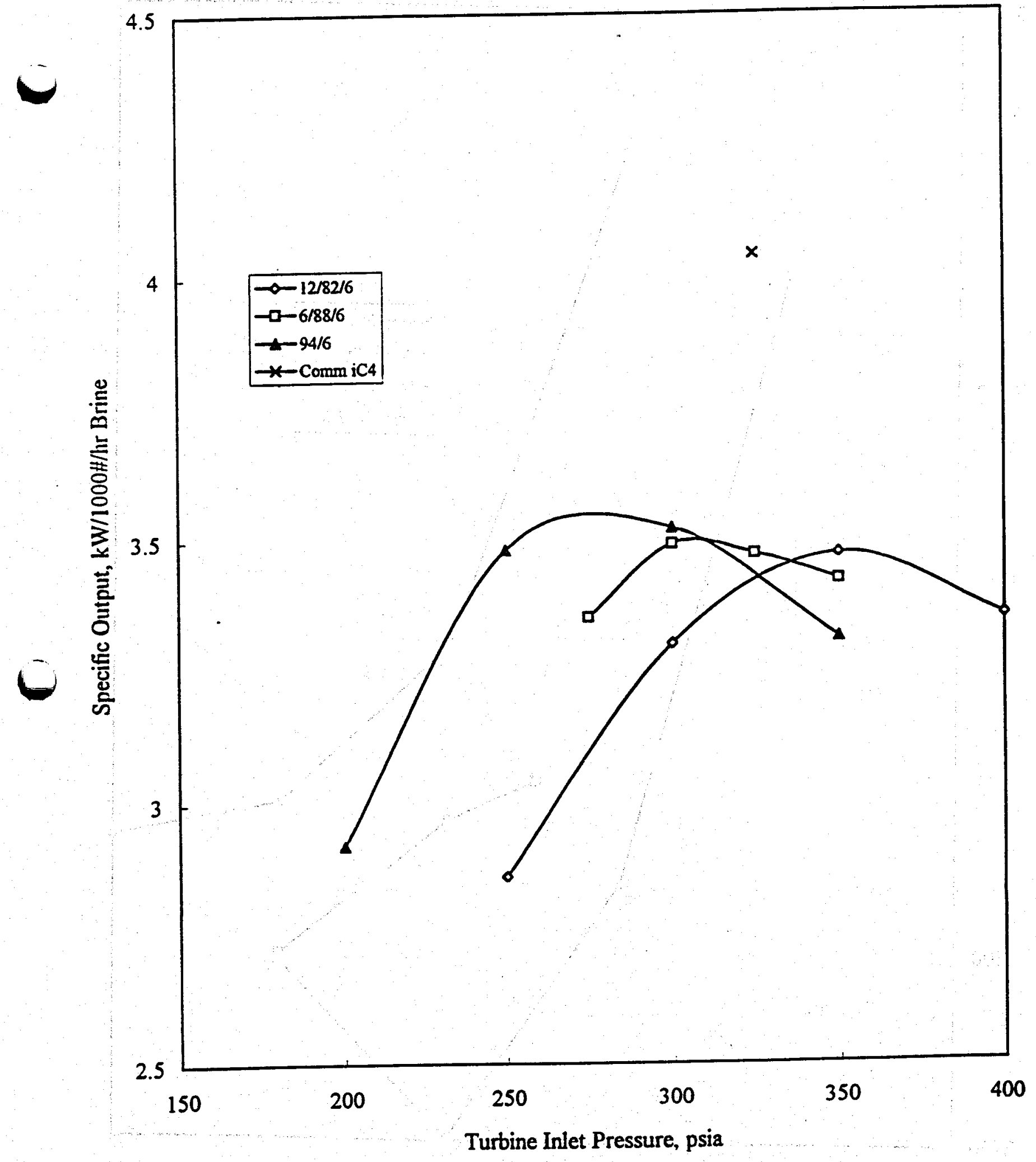

Figure 6-6

Mixed Fluids Specific Output Curves (RR) 


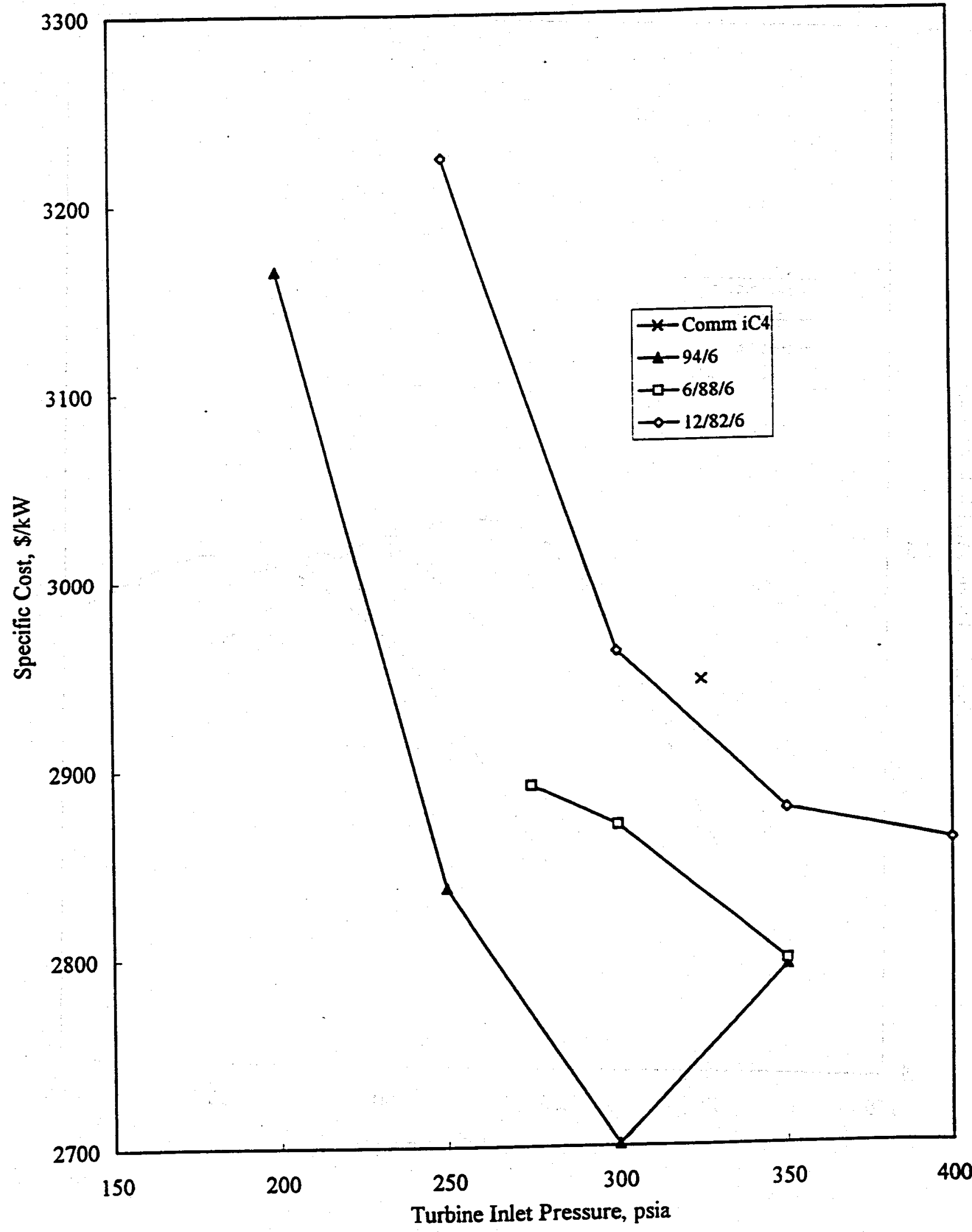

Figure 6-7

Mixed Fluids Specific Capital Cost Curves Curves (RR) 


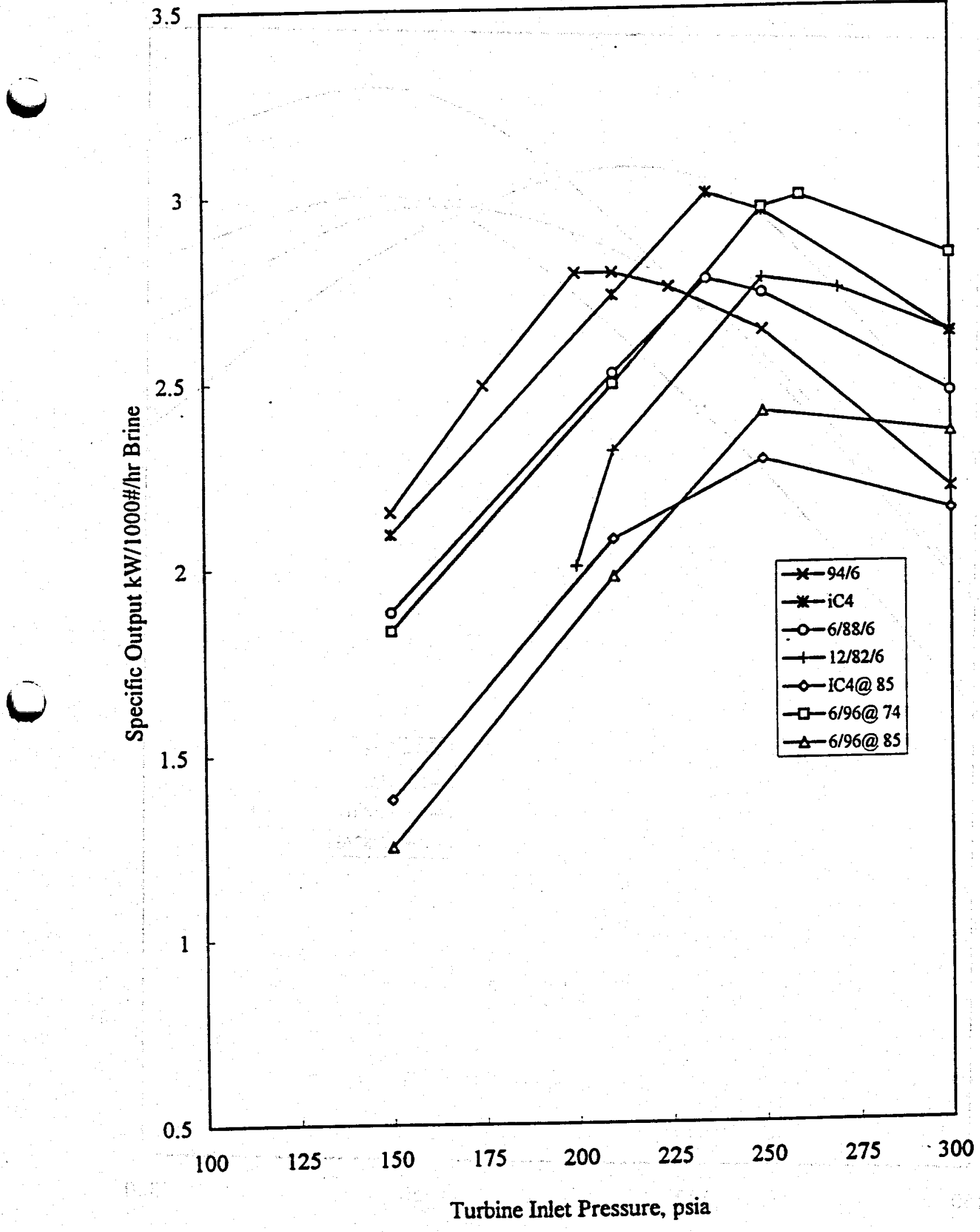

Figure 6-8

Mixed Fluids: Optimizing Condensing Temperatures (THS) 


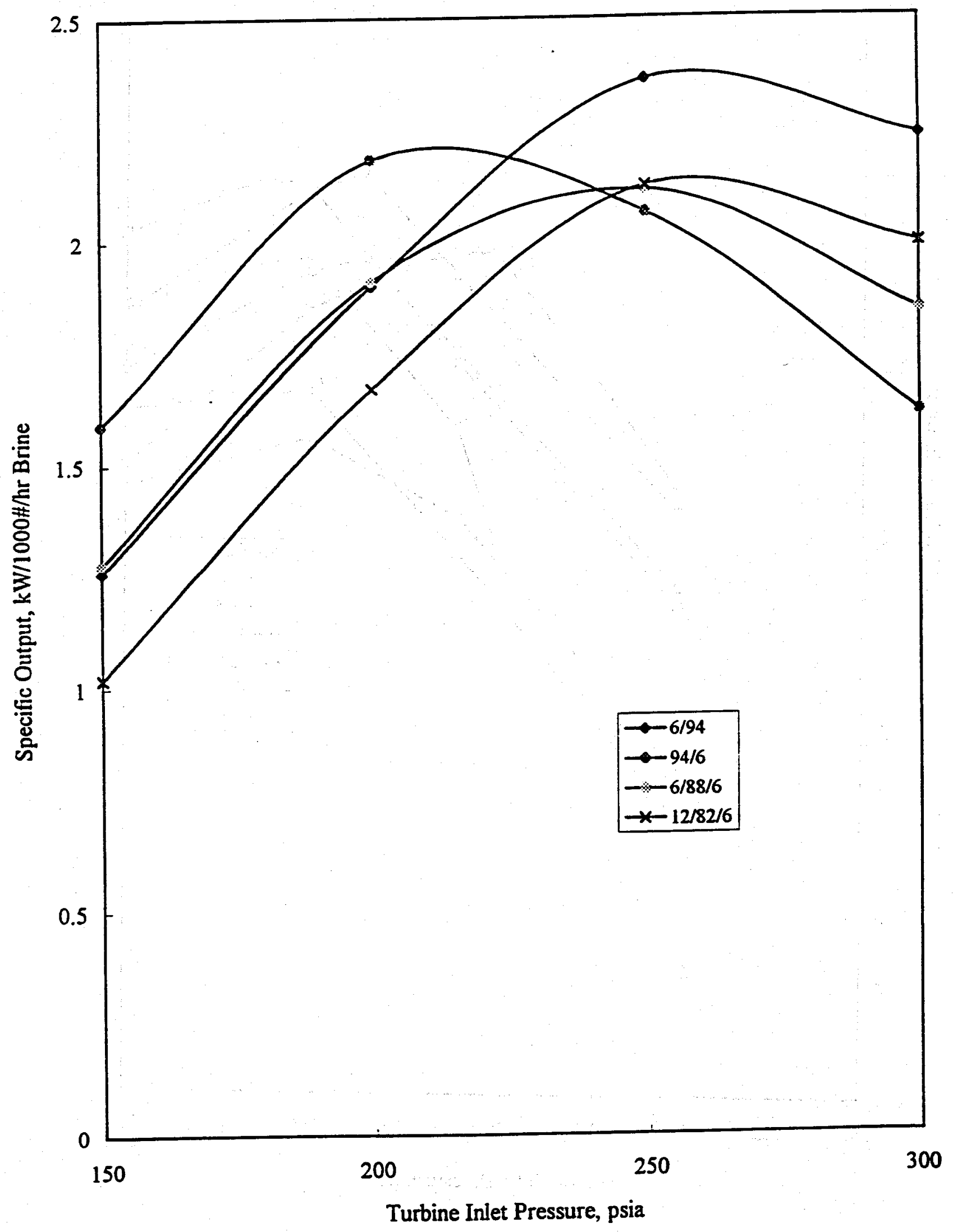

Figure 6-9

Mixed Fluids Specific Output Curves (THS) 


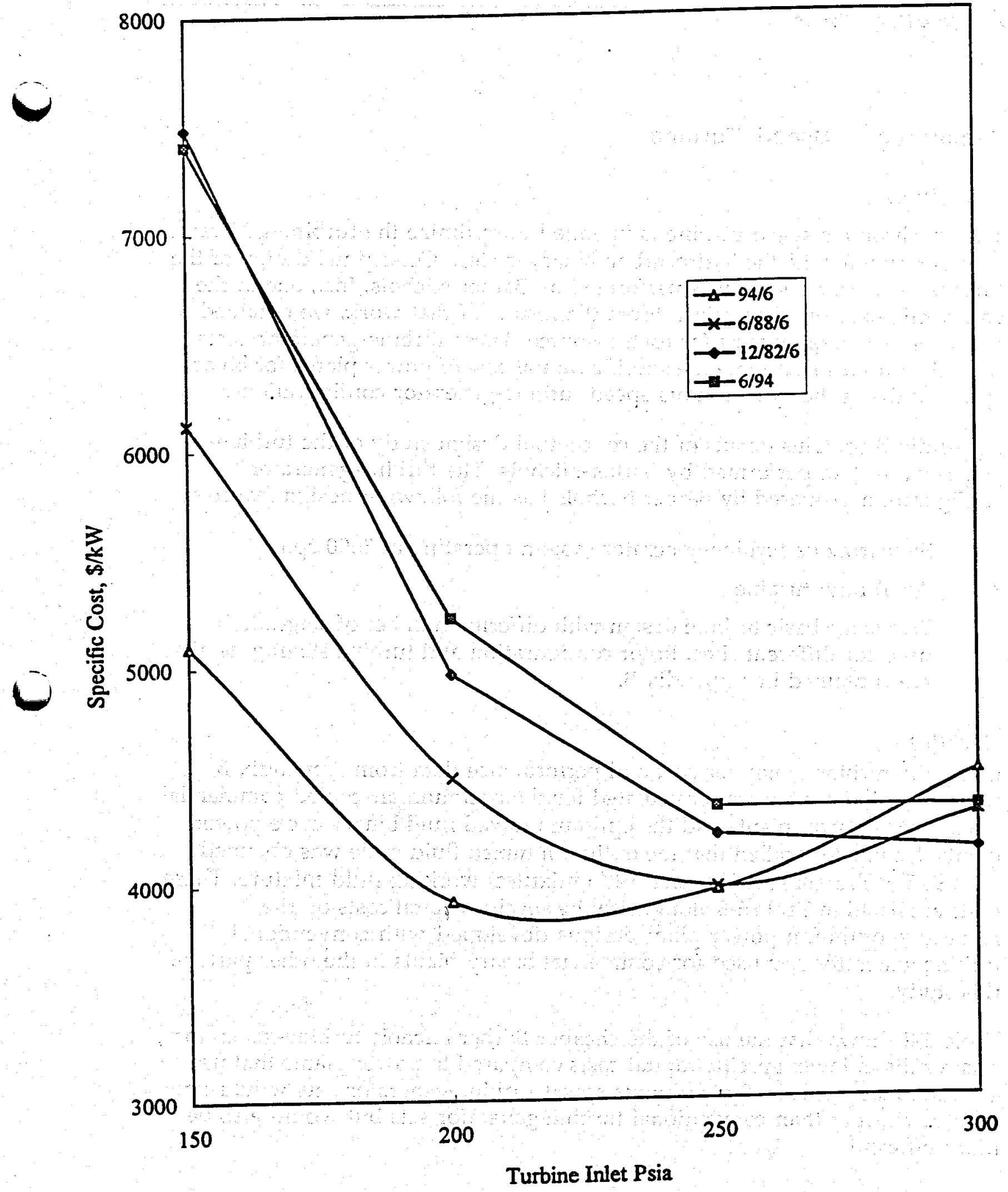

Figure 6-10

Mixed Fluids Specific Capital Cost Curves Curves (THS) 


\section{Synchronous Speed Turbine}

\section{Introduction}

The synchronous speed turbine is intended to optimize the turbine-generator configuration for the the hydrocarbon binary cycles. Conceptual design of the turbine-generator system was performed by Barber-Nichols, Inc., one of the co-investigators on this project. From the results of that work, we obtained the turbine-generator costs for each resource. These turbine-generator costs were then used to calculate the specific capital cost of power plants for binary cycles utilizing the synchronous speed turbine-generator configurations.

Appendix B contains details of the conceptual design study of the turbinegenerator system performed by Barber-Nichols. The turbine-generator configuration proposed by Barber Nichols has the following design features:

- Synchronous turbine-generator system operating at $3600 \mathrm{rpm}$

- Axial flow turbine

- Five stage basic turbine design with differing number of stages to be used for different sites. Rotor configuration and turbine staging details are contained in Appendix B.

\section{Results}

Using the turbine-generator cost and performance data from Appendix B, specific capital costs were recalculated for the optimum air-cooled commercial binary cycle power plants and the optimum mixed fluid binary cycle power plants. It may be recalled that the optimum mixed fluid cycle was obtained with $94 \%$ isobutane/6\% heptane ( $94 / 6$ mixture) working fluid mixture. These costs are listed in Table 6-8 along with the specific capital costs of the respective optimum power plant designs developed with conventional turbine-generator sets used for commercial binary plants in the other parts of this study.

Table 6-8 shows that the use of the cheaper Barber Nichols turbine-generator sets results in lower specific capital costs compared to power plants that use conventional turbines. Synchronous speed turbine-generator sets would not only be cheaper than conventional turbine-generator sets but would also be more efficient. 
Table 6-8

Comparison of Turbines

\begin{tabular}{|l|c|c|}
\hline \multicolumn{1}{|c|}{ Cycle Type } & $\begin{array}{c}\text { Commercial Binary } \\
\$ / \mathrm{kW}\end{array}$ & $\begin{array}{c}\text { Synchronous Speed } \\
\$ / \mathrm{kW}\end{array}$ \\
\hline Conventional Binary & 2070 & 1726 \\
Glass Mountain & 2115 & 1817 \\
Surprise Valley & 2184 & 2072 \\
Vale & 2942 & 2841 \\
Raft River & 4193 & 3924 \\
Thermo Hot Springs & & \\
& & \\
Mixed Fluids & 1861 & 1770 \\
(94 iC4/6 C7) & 2356 & 2346 \\
Surprise Valley & 2696 & 2541 \\
Vale & 3966 & 3633 \\
Raft River & & \\
Thermo Hot Springs & & \\
\hline
\end{tabular}




\section{Metastable Expansion}

\section{Introduction}

To maximize turbine efficiency, commercial binary plants are usually designed with enough superheat in the the turbine inlet vapor so that the subsequent expansion remains entirely in the vapor region. Metastable expansion technology aims to improve specific output of super-critical cycles by minimizing superheat in the turbine inlet vapor, and expanding the working fluid in the turbine through the two phase region. Expansion in the turbine through the two phase region is intended to take place at a rapid rate so that liquid droplets are not formed and the expansion is metastable. Working fluid enters the turbine as vapor, passes into, through and exits the two phase region while still in the turbine nozzles, and leaves the turbine as superheated vapor. During the expansion through the dome, the working fluid remains in the vapor state as a supersaturated vapor, and liquid does not form. As a result, turbine performance does not suffer during metastable expansion. (Mines 1994a)

Experimental studies have demonstrated that metastable expansion can be obtained during isentropic expansion in the two phase region. (Mines 1994b) However, these studies observed significant erosion of the turbine inlet nozzles, and it appears that further advances in the technology are required to develop the ideal metastable cycle.

Metastable expansion technology is applied near the critical point of the working fluid, a region of phase equilibria characterized by uncertainty in data. Consequently, different thermodynamic models in the critical point region can give substantially different results. Therefore, for a meaningful assessment of metastable expansion technology to emerge, the relative effect of model differences must be understood. Towards that end, calculations were made to compare with values reported in the literature. These calculations were made using the assumptions in the literature rather than the assumptions used in this study.

\section{Cycle Process Flow}

Metastable expansion technology is applicable to standard binary cycles and the reader is referred to section 5 for a typical process flow diagram and description.

\section{Literature Comparison}

\section{Performance Analysis}

Figure 6-11 replots the literature data for a hypothetical isobutane binary cycle at $550 \mathrm{psia}$ and a $10^{\circ} \mathrm{F}$ heat exchanger approach, for a $335^{\circ} \mathrm{F}$ resource (Mines 
1994c). Using a turbine inlet temperature of $290^{\circ} \mathrm{F}$ as the reference, the figure shows the incremental effect on specific output, hydrocarbon/brine ratio, and turbine enthalpy drop reported by Mines as the turbine inlet temperature is reduced from $290^{\circ} \mathrm{F}$ to $280^{\circ} \mathrm{F}$. The figure also shows results for the same calculations obtained with the thermodynamic model used in this study. A comparison of the two sets of data reveals that although the data are directionally similar, significant differences in magnitude exist. For example, the incremental improvement in specific output calculated using this study's model is only about half of that reported by Mines.

We believe that the differences between the two sets of data can largely be ascribed to differences in the respective equations of states. The Mines values were calculated using the NIST-12 model for pure isobutane; this study used the Starling equation of state. In order to further identify the differences in these models, the two equations of state were used to prepare a plot of temperature versus enthalpy for pure isobutane, Figure 6-12. Figure 6-12 also shows the temperature-enthalpy plot for commercial isobutane calculated using the Starling equation of state. It is evident from the figure that the predictions of the two equations of state diverge near the critical point (the region used for metastable expansion). In the region of the critical point, enthalpy differences as large as $12 \mathrm{Btu} / \mathrm{lb}$ hydrocarbon occur.

The question as to which equation of state is correct is an important question but one that is beyond the scope of this study. There are few reliable data available to validate the models, and the uncertainty surrounding calculations in the critical point region will not be eliminated without further research.

\section{Cost Analysis}

Using a hypothetical, isobutane binary cycle it has been shown that binary cycles with metastable expansion can yield higher specific output than commercial (non-metastable exapansion) binary cycles (Mines 1993) and the improvement in specific output was confirmed in this study. However, for that hypothetical cycle ( $550 \mathrm{psia}, 10^{\circ} \mathrm{F}$ pinch, $335^{\circ} \mathrm{F}$ resource), the higher specific output with metastable expansion did not result in a power plant with a lower specific capital cost compared to a power plant based on the commercial binary cycle.

Figure 6-13 plots the ratio of specific capital costs for the metastable binary cycle to the commercial binary cycle. As can be seen from the figure, the metastable power plant cost is up to $2 \%$ more than the binary power plant cost. The metastable expansion binary power plant has a higher capital cost due to increased hydrocarbon circulation, higher heat exchanger costs due to lower LMTDs, and larger size and cost of turbine-generator sets due to lower turbine enthalpy drops. Table 6-9 provides a comparative equipment cost 
summary for the metastable and commercial binary cycles for the above mentioned hypothetical case.

\section{NGGPP Study}

\section{Performance Analysis}

Binary cycles with metastable expansion were analyzed using the same methodology that was used to model the commercial binary cycles in Section 5. Cycle thermodynamics were modeled using the Starling equation of state. Although this study's evaluation of metastable expansion technology might differ from an evaluation obtained using a different equation of state, for example NIST-12, our approach allows a meaningful comparison of metastable expansion technology with other binary technologies.

In order to determine the specific output and cost per kilowatt of electricity, binary cycles using metastable expansion were applied to three sites: Surprise Valley, Vale, and Raft River. The resource at Thermo Hot Springs is too cool for a supercritical cycle based on isobutane to be used and was therefore not considered.

In general, the assumptions used for simulating commercial binary cycles were also used to simulated binary cycles with metastable expansion. Two key assumptions used in the development of binary cycles with metastable expansion need to be highlighted.

- First, a turbine efficiency of $85 \%$ with no loss of turbine efficiency during the expansion through the two phase region was assumed. Although the vapor is thought to remain in a supersaturated condition as it passes through the turbine, recent test have shown signs of erosion within the inlet nozzles (Mines 1994). However, at the time of this writing the effect of nozzle erosion on turbine effieciency is not clear.

- Second, the brine injection temperature was limited to a minimum of $150^{\circ} \mathrm{F}$, the minimum injection temperature specified by EPRI for the three sites considered for metastable expansion. In our literature comparison study, brine outlet temperature was allowed to decrease at lower turbine inlet temperatures.

\section{Cost Analysis}

The cost analysis methodology for binary cycles with metastable expansion was identical to that used for cost analysis of commercial binary cycles as described in Section 5 . 


\section{Results}

Specific output curves for the metastable binary cycles evaluated in this study are plotted in Figures 6-14, 6-15 and 6-16 for Vale, Surprise Valley, and Raft River, respectively. Specific output for the respective commercial binary cycles are also shown on the figures. It is evident that the optimum commercial binary cycles yield a higher specific output compared to the corresponding metastable expansion cycles.

Table 6-10 summarizes the performance of metastable expansion binary cycles; the table also lists the specific capital cost for the optimum commercial binary cycles. For two of the sites, the baseline binary cycle has a slightly lower specific capital cost and for the third (Raft River), metastable expansion is slightly lower. It is clear that metastable expansion does not offer a dramatic improvement over current technology. The table also shows that the metastable expansion binary cycle that yields the maximum specific output does not correspond to the lowest specific capital cost for the three resources considered in this study. 
Table 6-9

Metastable Expansion: Comparison of Equipment Costs

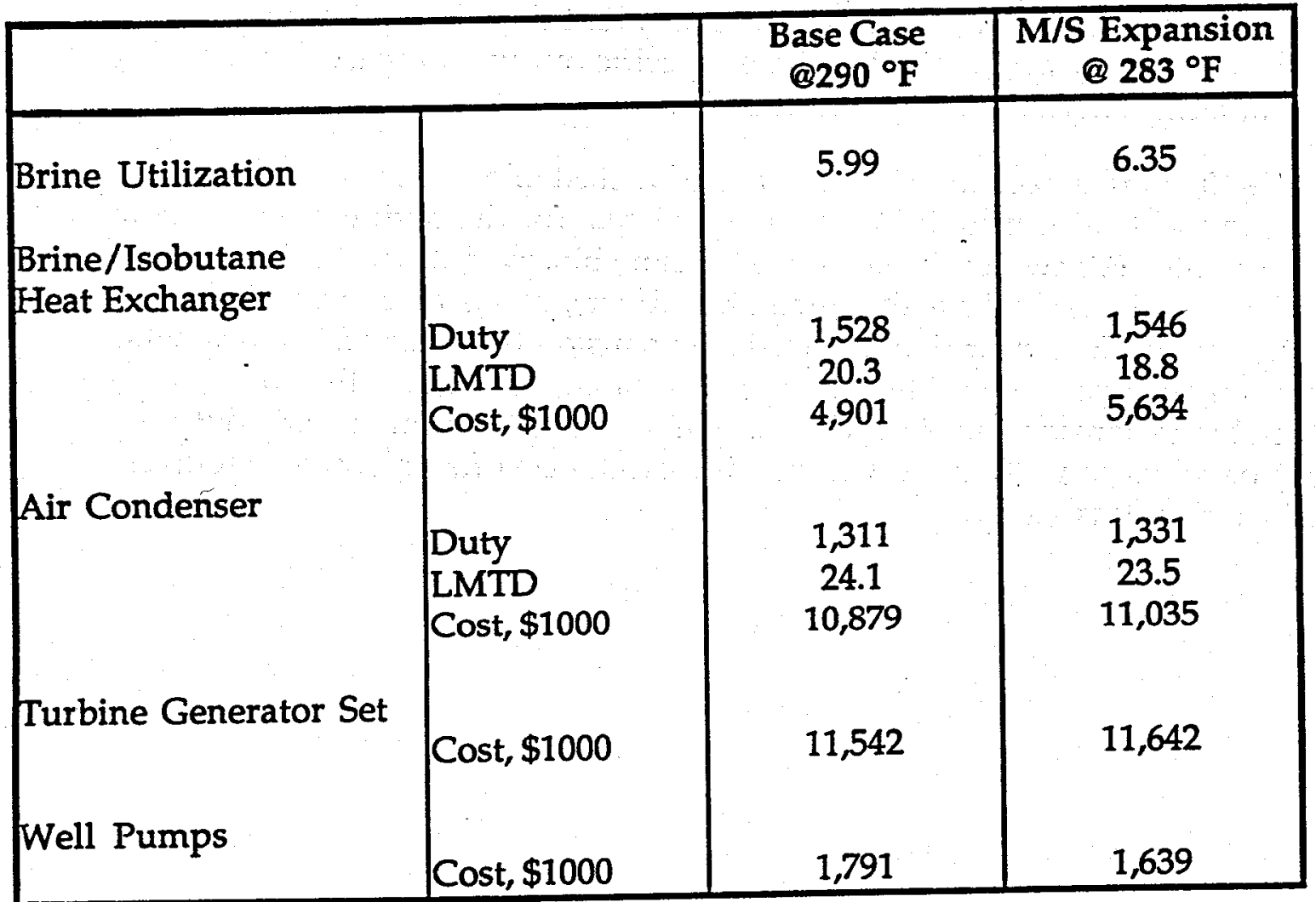

Table 6-10

Metastable Expansion Summary of Cases

\begin{tabular}{|c|c|c|c|c|c|c|}
\hline & \multicolumn{4}{|c|}{ Metastable Expansion } & \multirow{2}{*}{\multicolumn{2}{|c|}{$\begin{array}{c}\text { Commercial Binary } \\
\text { Economic Optimum } \\
\text { Case }\end{array}$}} \\
\hline & $\begin{array}{l}\text { Maximur } \\
\text { Outp1 }\end{array}$ & $\begin{array}{l}\text { Specific } \\
\text { t Case }\end{array}$ & Economi & $\begin{array}{l}\text { Optimum } \\
\text { se }\end{array}$ & & \\
\hline Resource & $\begin{array}{c}\text { Turbine } \\
\text { Inlet }\end{array}$ & $\begin{array}{c}\text { Cost } \\
(\$ / k W)\end{array}$ & $\begin{array}{c}\text { Turbine } \\
\text { Inlet }\end{array}$ & $\begin{array}{c}\text { Cost } \\
(\$ / k W)\end{array}$ & $\begin{array}{c}\text { Turbine } \\
\text { Inlet }\end{array}$ & $\begin{array}{c}\text { Cost } \\
(\$ / k W)\end{array}$ \\
\hline Vale, Oregon & $\begin{array}{l}700 \text { psia, } \\
306.9^{\circ} \mathrm{F}\end{array}$ & 2,486 & $\begin{array}{l}600 \text { psia, } \\
289.6^{\circ} \mathrm{F}\end{array}$ & 2,464 & $\begin{array}{l}500 \text { psia, } \\
277^{\circ} \mathrm{F}\end{array}$ & 2,440 \\
\hline $\begin{array}{l}\text { Surprise } \\
\text { Valley }\end{array}$ & $\begin{array}{l}1050 \text { psia, } \\
353^{\circ} \mathrm{F}\end{array}$ & 2,217 & $\begin{array}{l}500 \text { psia, } \\
269.6^{\circ} \mathrm{F} \\
\end{array}$ & 2,157 & $\begin{array}{l}850 \text { psia, } \\
353^{\circ} \mathrm{F}\end{array}$ & 2,115 \\
\hline Raft River & $\begin{array}{l}450 \text { psia, } \\
255^{\circ} \mathrm{F}\end{array}$ & 3,024 & $\begin{array}{l}350 \text { psia, } \\
228.4^{\circ} \mathrm{F}\end{array}$ & 2,925 & $\begin{array}{l}325 \text { psia, } \\
221{ }^{\circ} \mathrm{F}\end{array}$ & 2,945 \\
\hline
\end{tabular}




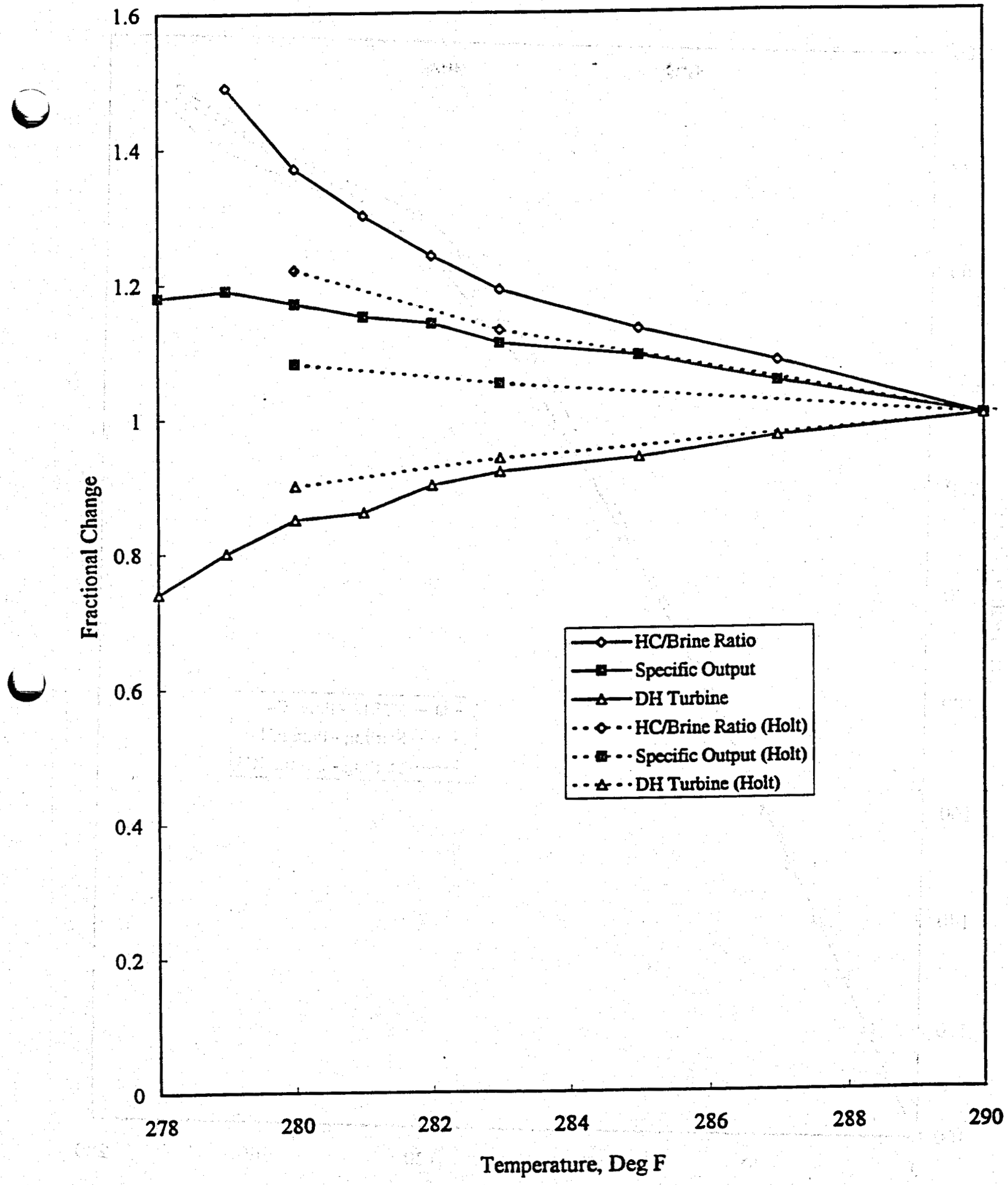

Figure 6-11

Metastable Expansion for Hypothetical Cycle 


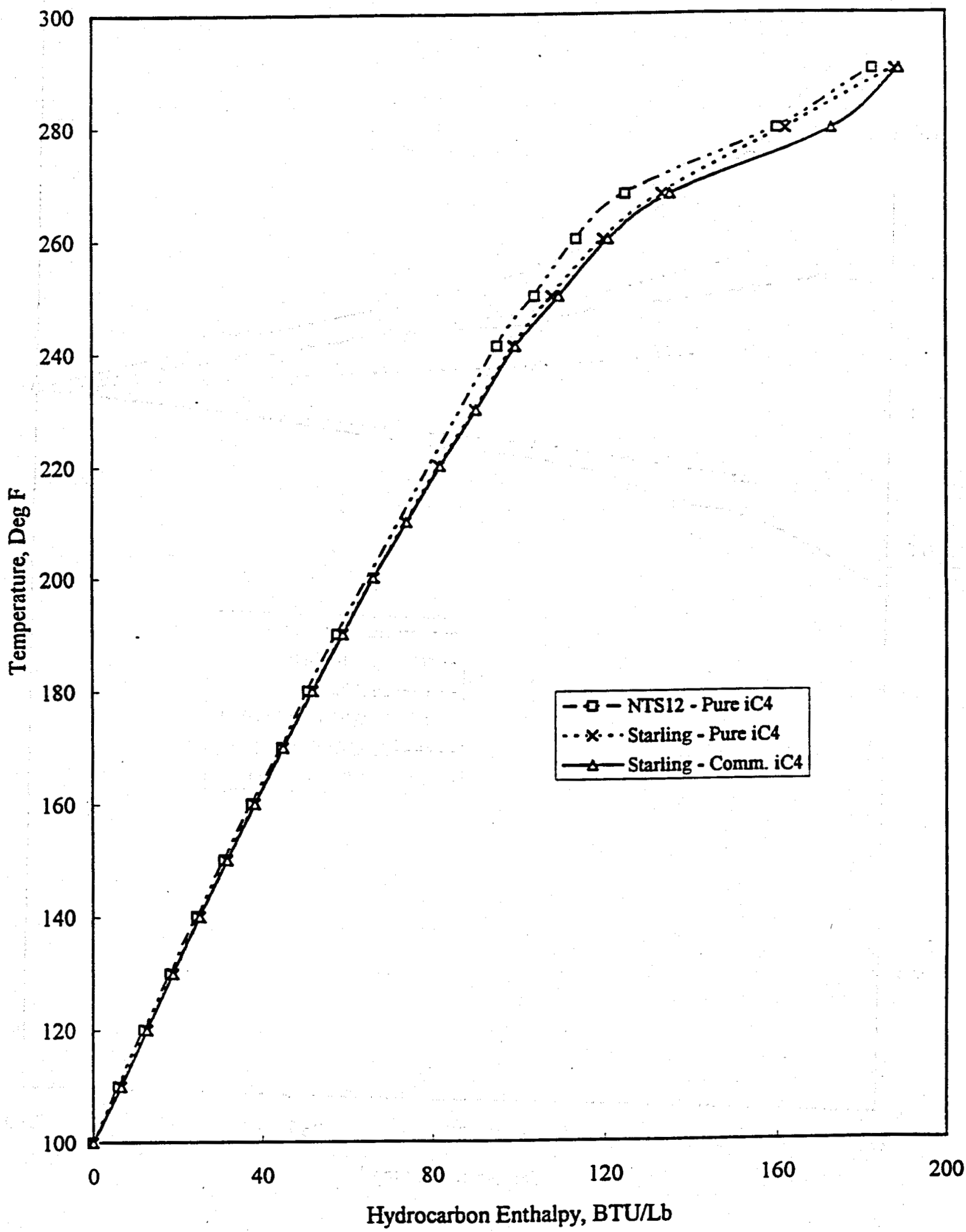

Figure 6-12

Comparison of NIST-12 and Starling Equation of State 


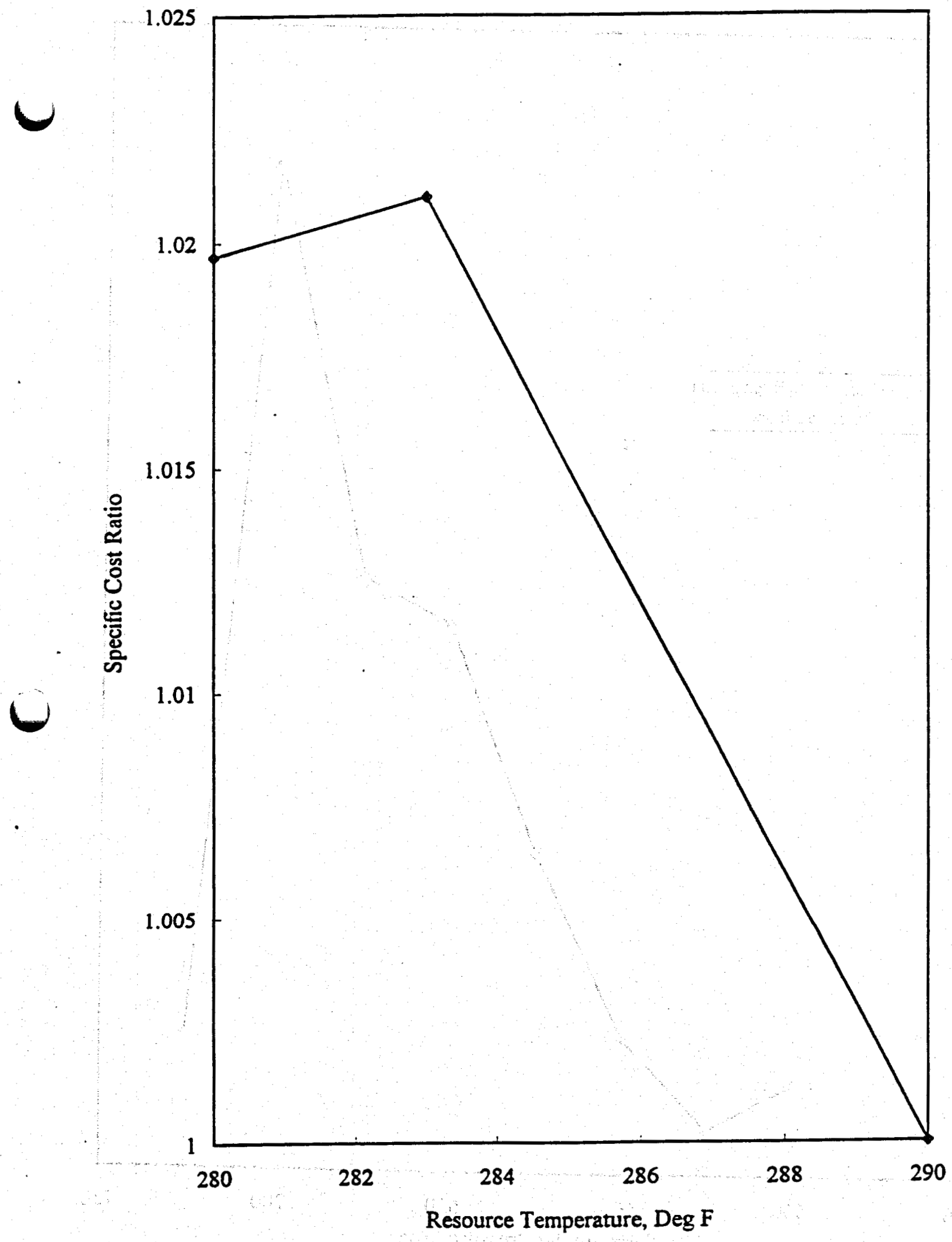

Figure 6-13

Ratio of Metastable Expansion and Commercial Binary Costs 


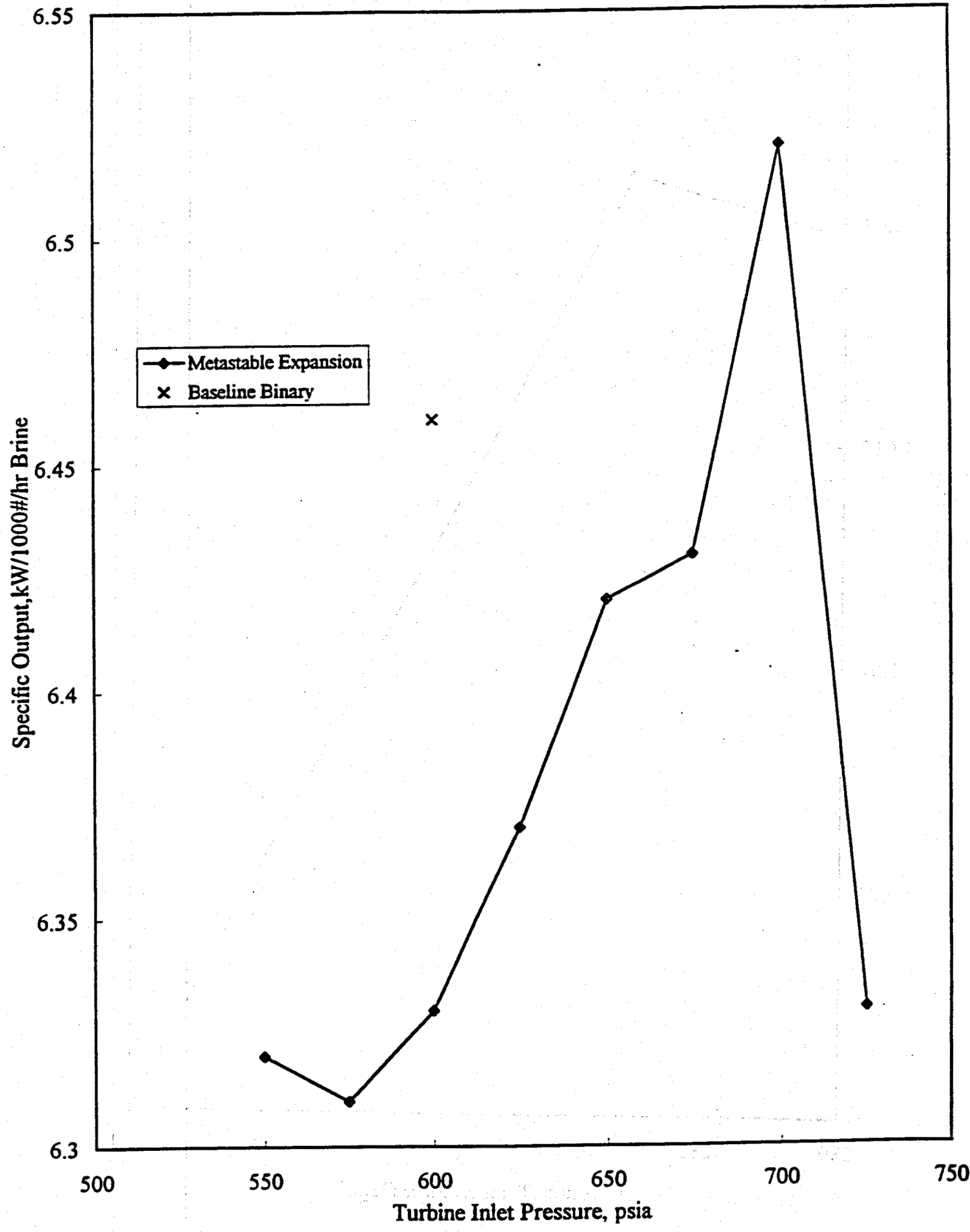

Figure 6-14

Metastable Expansion Binary Specific Output Curves (VO)

6-30 


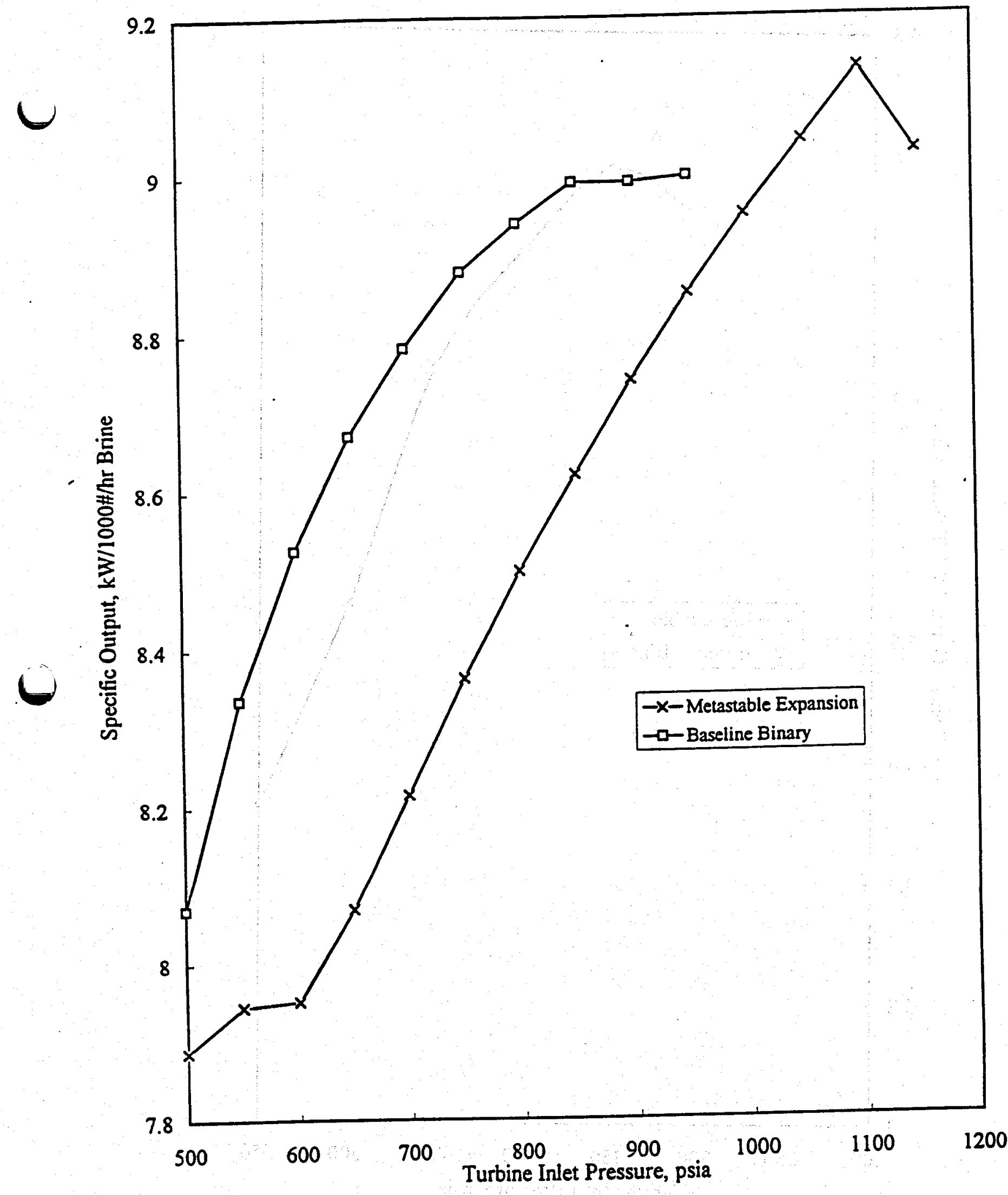

Figure 6-15

Metastable Expansion Binary Specific Output Curves (SV) 


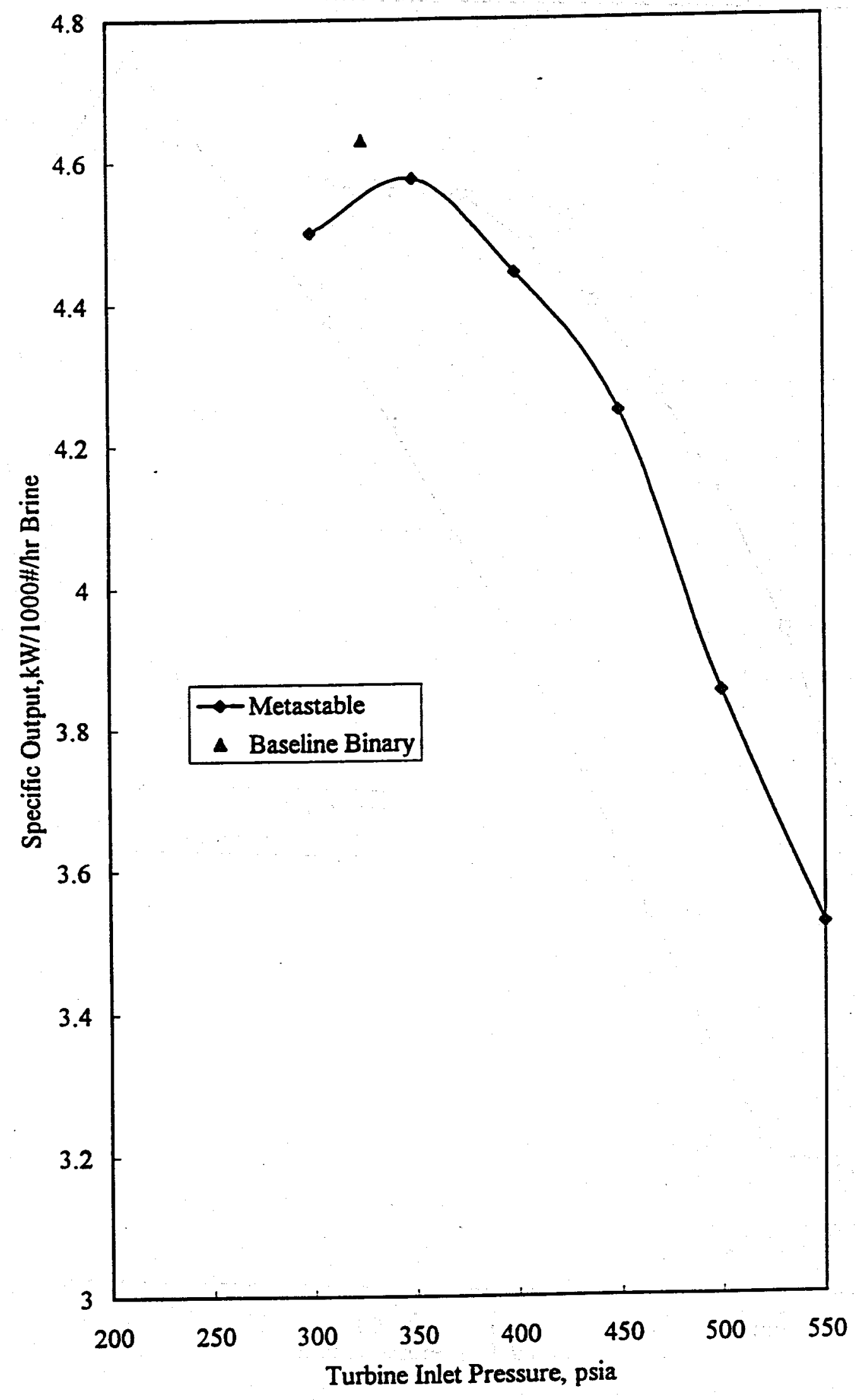

Figure 6-16

Metastable Expansion Binary Specific Output Curves (RR) 


\section{Binary Cycle: Hot Dry Rocks}

\section{Introduction}

Two cases were evaluated for heating brine with hot dry rocks, and using the heated brine to drive a binary unit to make electricity. The plant cost and the well field development costs were estimated in order to derive specific capital costs.

\section{Cycle Process Flow}

A schematic of the one possible well injection and production concept is shown in Figure 6-17 (Duchene, 1993).

\section{Performance Analysis}

Basic parameters including the 4,000 psia injection pressure and 1500 psia production well pressure were obtained from Table 4-1. Well drilling costs of $\$ 6,000,000$ (including fracturing) for $200,000 \mathrm{lb} / \mathrm{hr}$ wells were used to develop the well field costs. The hot brine temperature of $375{ }^{\circ} \mathrm{F}$ and reinjection temperature of $150^{\circ} \mathrm{F}$ were used to make the hot dry rock technology comparable to the Surprise Valley, California site.

To estimate water losses that will occur upon injection and production of the brine, Mr. Dave Duchene of the Los Alamos Laboratory was consulted. It appears that water losses are currently being estimated in the range of $7 \%$ (Duchene, 1994).

\section{Economic Analysis}

Heated brine from the hot dry rock system was fed to a binary cycle to develop specific capital cost estimates. Two types of binary cycles were used: a standard commercial binary cycle unit at 500 PSIA \& $277^{\circ} \mathrm{F}$ and a mixed fluids $(94 \%$ IC4 $\& 6 \%$ C7) cycle. The binary cycle cost model was modified to include the three pressure tiers used by the injection wells at Los Alamos (Duchene, 1993). It was also modified to adjust the brine/hydrocarbon heat exchangers for the high tubeside pressures that would be encountered with the high pressure brine.

\section{Results}

A $50 \mathrm{MW}$ plant using a standard 500 psia binary cycle would cost $\$ 9,500 / \mathrm{kW}$, and a $50 \mathrm{MW}$ plant using $94 / 6$ mixed fluids would cost $\$ 8,900 / \mathrm{kW}$. These specific capital costs are much higher than those for the other binary units. Two significant factors are largely responsible for the high costs of power plants that would use hot dry rocks as a source of energy: (1)the high well field parasitic load which consumes $30 \%$ of the gross power production, and (2) the $\$ 6,000,000$ to drill and fracture each injection/production well pair. Moreover, the flow per well is only $200,000 \mathrm{lbs} / \mathrm{hr}$ per well which leads to a 

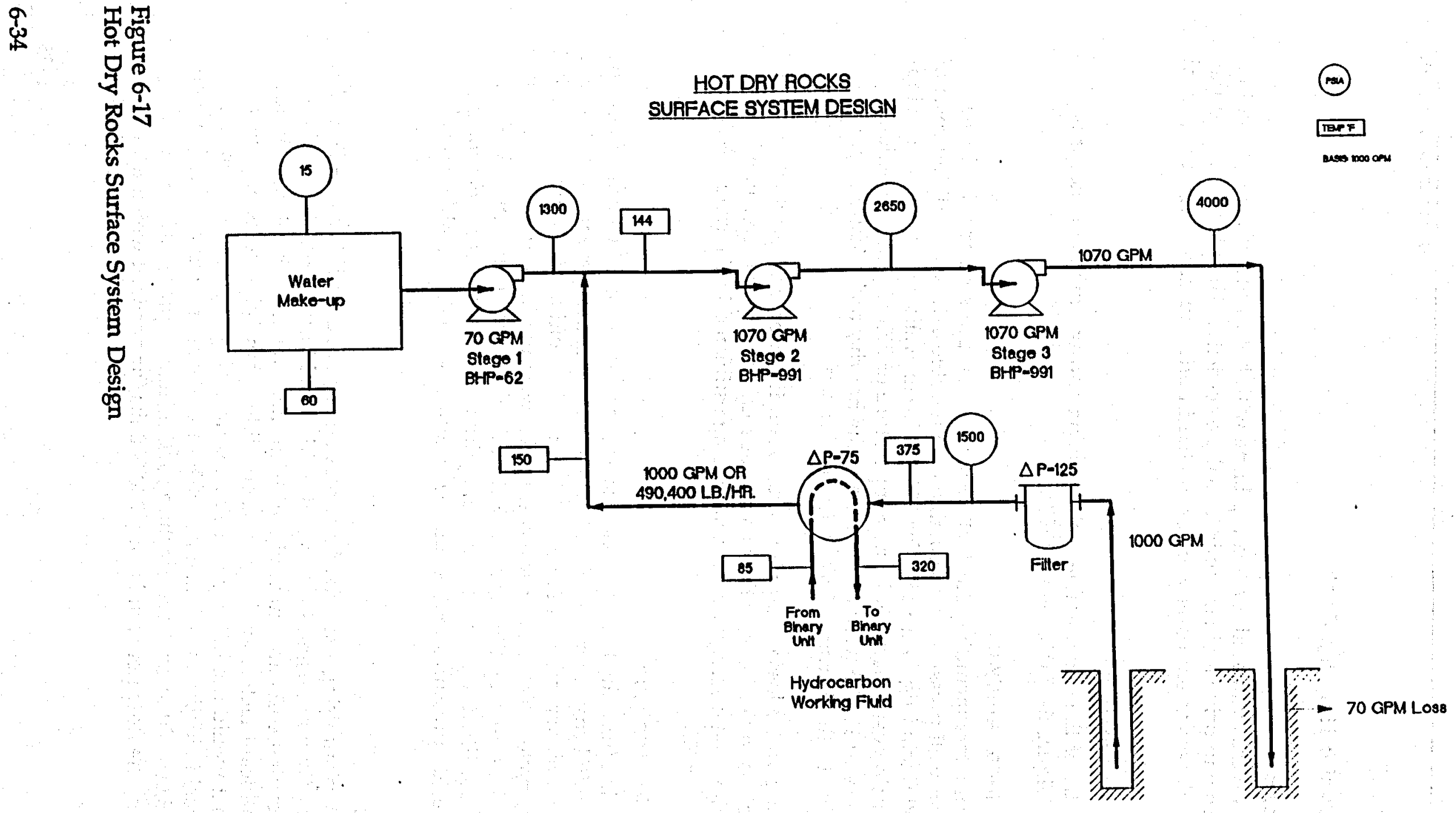

C 


\section{ADVANCED FLASH CYCLES}

\section{Dual Flash/Rotary Separator Turbine}

\section{Introduction}

This section discusses the evaluation of geothermal power plants that use dual flash plant/rotary separator turbine (Dual Flash/RST) technology. In contrast to a conventional dual flash plant in which the geothermal brine is flashed isenthalpically across a throttle valve, in a flash plant that uses rotary separator turbine (RST) technology the brine is flashed across a two phase nozzle. Since the brine expands more isentropically across the nozzle than the throttle valve, less available energy is lost in the rotary separator turbine the compared to the available energy lost across the throttle valve in a dual flash plant. (Cerini and Hays, 1980)

\section{Cycle Process Flow}

Figure 7-1 is the process flow diagram for a dual flash plant with a rotary separator turbine downstream of the production well. The rotary separator turbine replaces the high pressure separator in a conventional dual flash plant, and it performs the functions of flashing the geothermal brine, and separating liquid brine from high pressure steam. It also generates power from the two phase stream in the process of separating it.

In essence, the rotary separator turbine combines a liquid impulse turbine with an axial steam turbine on the same shaft. The impulse turbine extracts work from liquid brine and the axial turbine extracts work from steam. Steam from the RST then flows to the geothermal steam turbine and the brine is sent to the low pressure separator. The remaining process steps are the same as those in a conventional dual flash plant.

\section{Performance Analysis}

Dual flash/RST technology was evaluated for the following geothermal sites: Desert Peak, Dixie Valley, Glass Mountain, Coso, and Salton Sea. 


\section{Description}

In a geothermal power plant utilizing dual flash/rotary separator turbine technology, the plant downstream of the rotary separator turbine (RST) is a conventional dual flash plant, as noted above. Thus, the modeling assumptions and methodology that apply to a dual flash plant also apply to the dual flash section of plant based on dual flash/RST technology.

The power output from the RST was found by using efficiency data generated by Douglas Energy, the RST developer, from a computer model. Model accuracy was confirmed by comparing its predictions to published experimental RST data (Cerini 1978). The overall efficiency of the RST is a function of inlet pressure, outlet pressure, and inlet vapor fraction. Turbine efficiency increases with an increase in each of these parameters, and inlet vapor fraction is the most significant of these parameters. An interpolation routine to calculate the overall efficiency of the RST using these parameters was added to the Holt dual flash model. Using the RST efficiency found from the correlation, the power output was calculated.

\section{Assumptions}

In addition to the general assumptions that were used to analyze dual flash power plants, the following specific assumptions were used to evaluate RST technology:

- Generator efficiency of $95 \%$.

- A homogeneous wellfield pressure distribution with wellhead pressures listed in Table 7-1.

- Pumped resources were not considered for application of RST technology because low resource enthalpies yield very low RST efficiencies.

- Although the RST can be directly used to inject liquid brine, this function of the RST was not used since liquid brine from the RST outlet would be flashed a second time (in the low pressure separator) in dual flash/RST plants.

\section{Cost Analysis}

\section{Description}

Overall cost methodology used to analyze dual flash/RST technology was the same as that used for dual flash power plants. A vendor quote of $\$ 472 / \mathrm{kW}$ for a $3 \mathrm{MW}$ unit was used as the basis for RST costs. Costs for civil, electrical, extra instrumentation, engineering, and installation/start up costs were 
added to equipment cost and the total multiplied by 1.35 (for indirect \& owners costs) to obtain the total installed cost. This results in an overall installed cost multiplier for the rotary separator turbine of about 1.8 compared to 2.53 for other dual flash plant equipment.

\section{Assumptions}

Specific assumptions used in the cost evaluation of dual flash/RST power plants were:

- A minimum price of $\$ 250,000$ for $0.53 \mathrm{MW}$ units or smaller.

- At least one RST per well pad.

\section{Results}

\section{Performance}

This study confirms that a dual flash /RST plant will yield a higher specific output compared to a conventional dual flash plant. The percent increase in specific output of a dual flash/RST plant over a conventional dual flash plant is plotted in Figure 7-2. For all the sites other than Salton Sea, specific output of dual flash/RST plants is only about 1 percent better than conventional dual flash plants. For these sites the wellhead pressures are already at or below the optimum high pressure flash pressure, and therefore the resources at these sites do not have to be throttled. Therefore the advantage that accrues from the more efficient expansion process in an RST is negated. Somewhat higher power is generated using the RST because the RST liquid turbine generates power from the liquid brine stream.

A process summary for the maximum specific output dual flash/RST plants is presented in Table 7-1 which confirms that only for Salton Sea is the wellhead pressure significantly higher than the optimum high pressure flash pressure for a dual flash plant. Wellhead pressure at Salton Sea is 325 psia which is almost 175 psi higher than the inlet pressure to the geothermal steam turbine since turbine inlet pressures are limited to 153 psia for steam turbines used in geothermal power plants for metallurgical reasons. Thus, the RST uses the additional 175 psi drop to produce power while the dual flash plant merely throttles the stream. As a result, specific output a of dual flash/RST plant at Salton Sea would be 7\% higher than that of a conventional dual flash power plant.

It appears then that RST technology would be beneficial in improving specific output for resources in which the wellhead pressure exceeds the allowable turbine inlet pressure because of technological or other constraints.
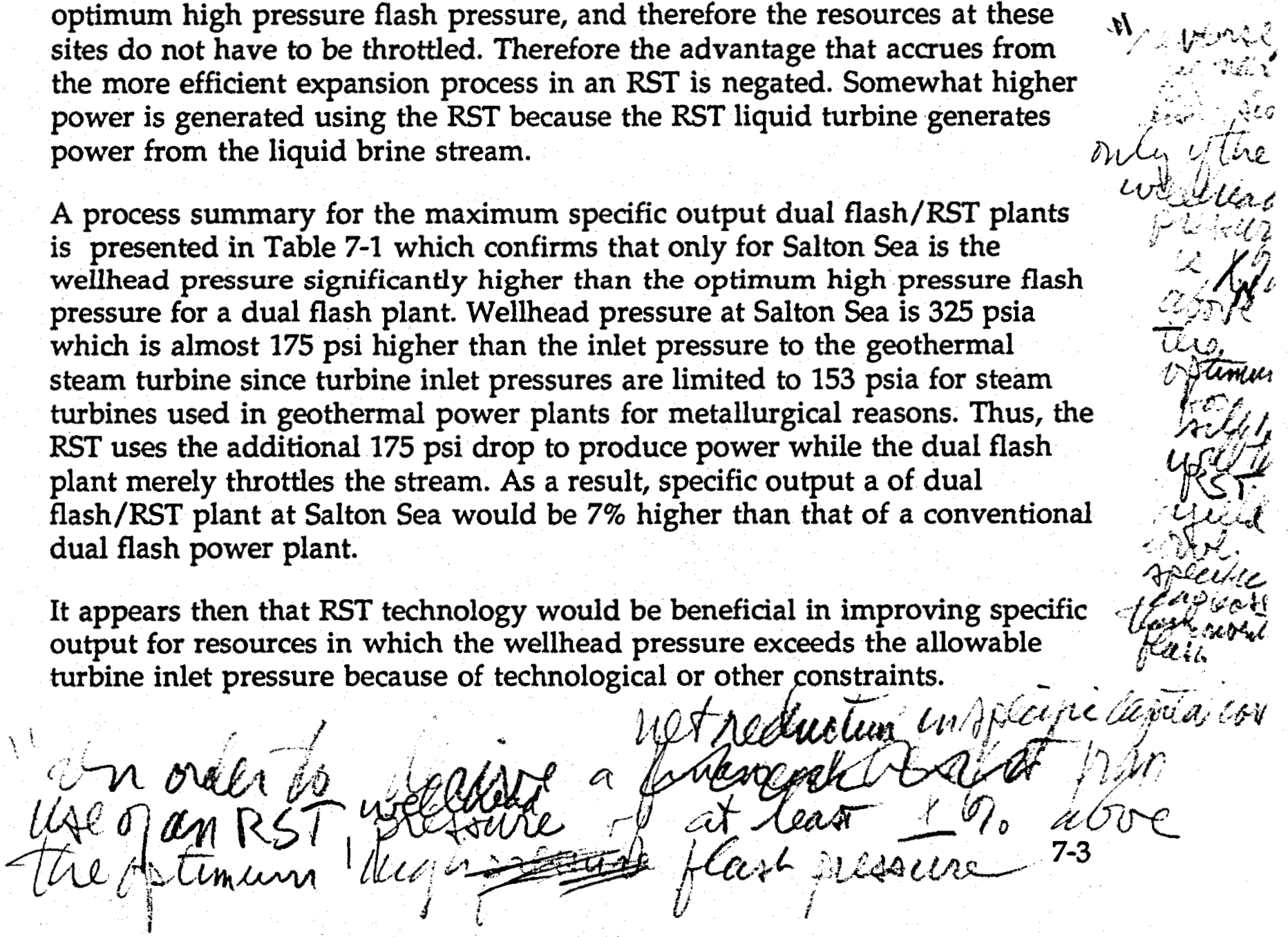


\section{Economics}

Cost analysis of the dual flash/RST technology was only performed for the resource at Salton Sea. Figure 7-3 is a plot of the specific capital cost versus flash pressure for a dual flash/RST power plant at Salton Sea. The specific capital cost of the optimum dual flash plant is also shown as a point on the figure. It is evident that specific capital cost of a conventional dual flash plant is lower than a dual flash/RST plant. Dual flash/RST plants are likely to have a higher specific capital cost than conventional dual flash power plants because of the large cost differential between an RST and a steam turbine: installed cost of an RST is $\$ 876 / \mathrm{kW}$ whereas the installed cost for a steam turbine is $\$ 585 / \mathrm{kW}$. The increased specific output that the RST yields is not sufficient to offset this cost differential. In fact, the highest specific capital cost point on Figure 7-3 corresponds to the highest specific output.

It would appear from Figure 7-3 that raising the flash pressure would lower the specific capital cost. However, it should be remembered that the flash pressure for both the RST and conventional dual flash plants is limited to 153 psia due to metallurgical constraints on the geothermal steam turbine. Removing this constraint would result in lower specific capital costs for the dual flash/RST plant but specific capital costs of conventional dual flash plants would also be lowered. 

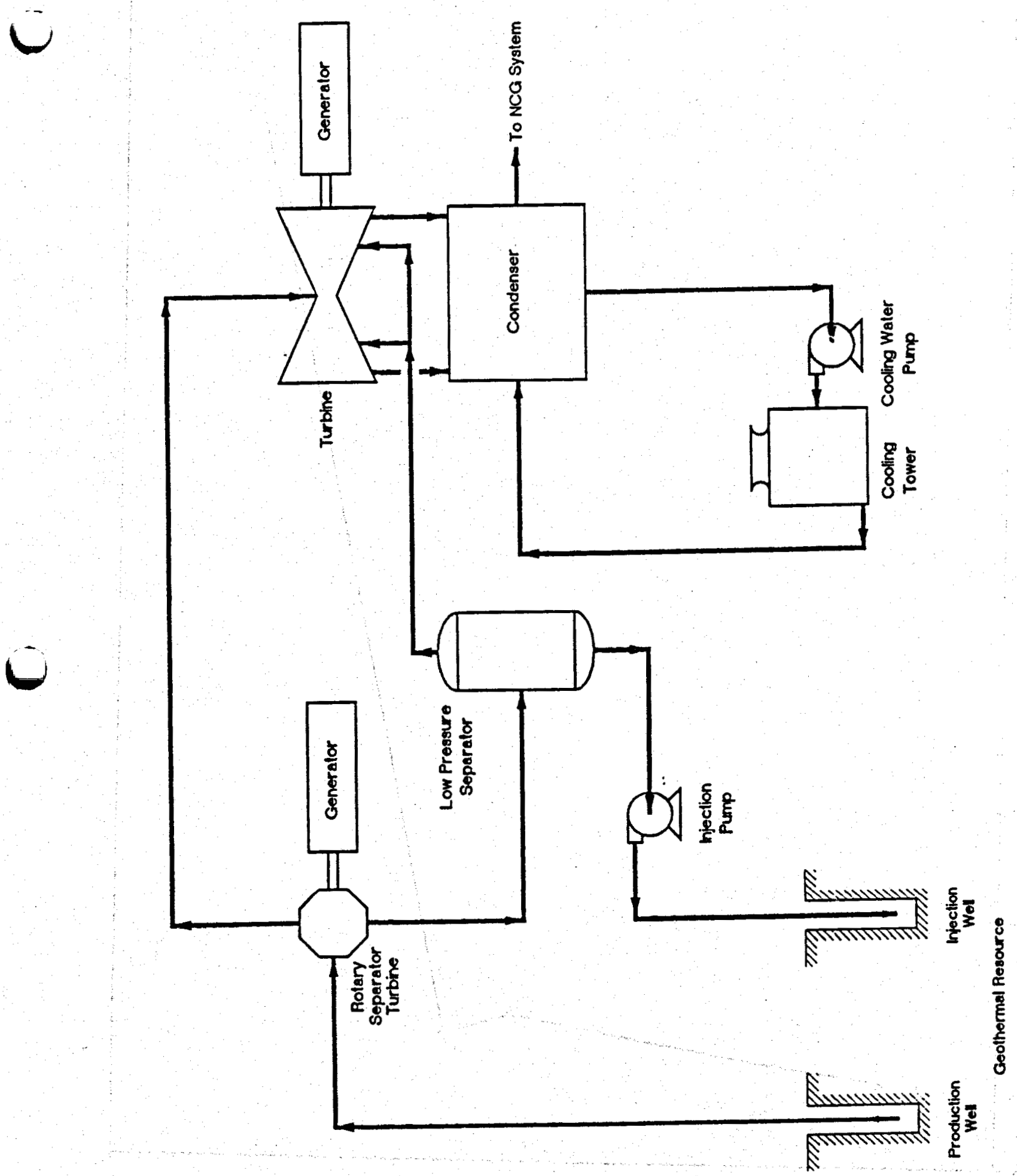

Figure 7-1

Dual Flash/Rotary Separator Turbine - Process Flow Diagram 


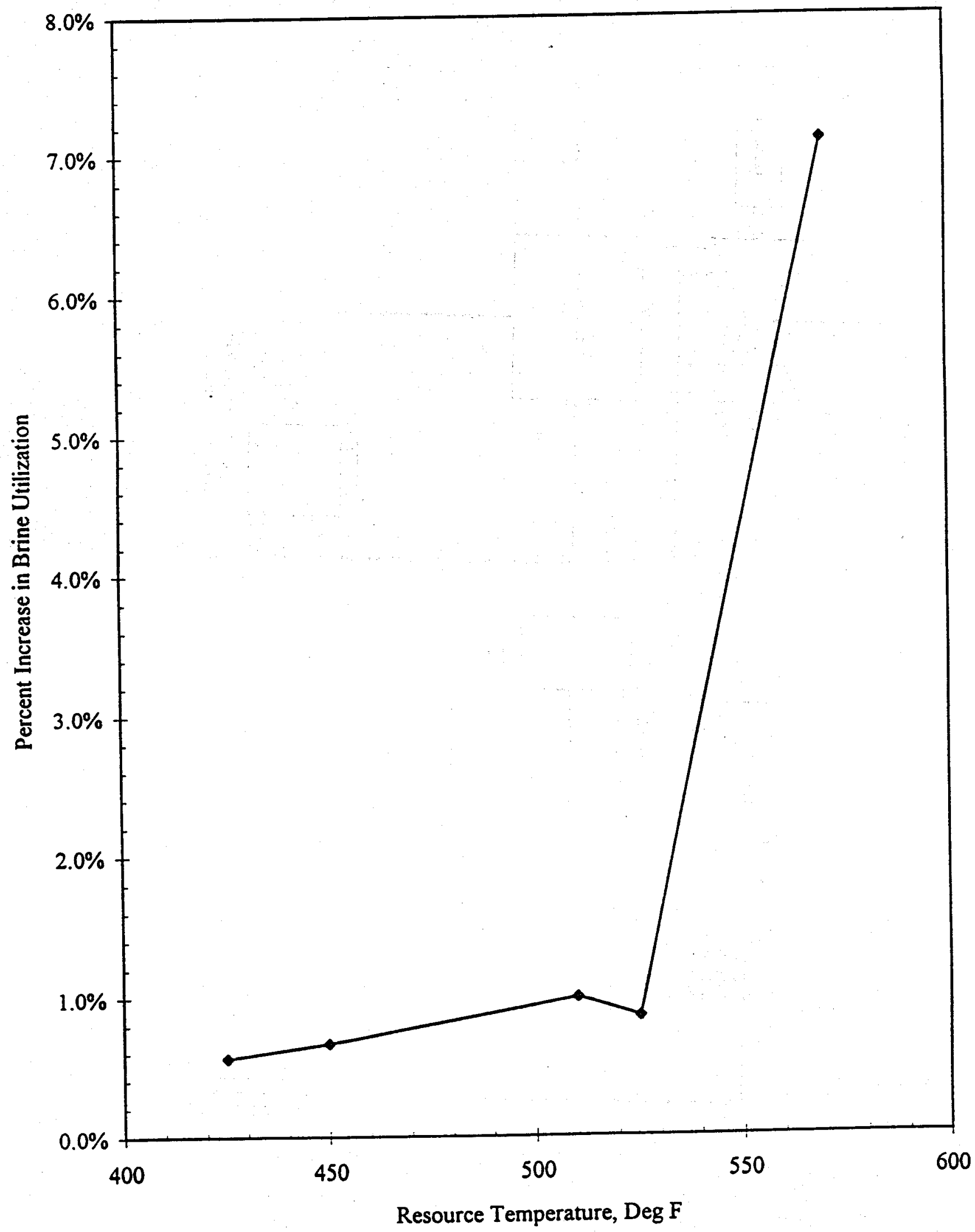

Figure 7-2: RST

Incremental Change in Specific Output 


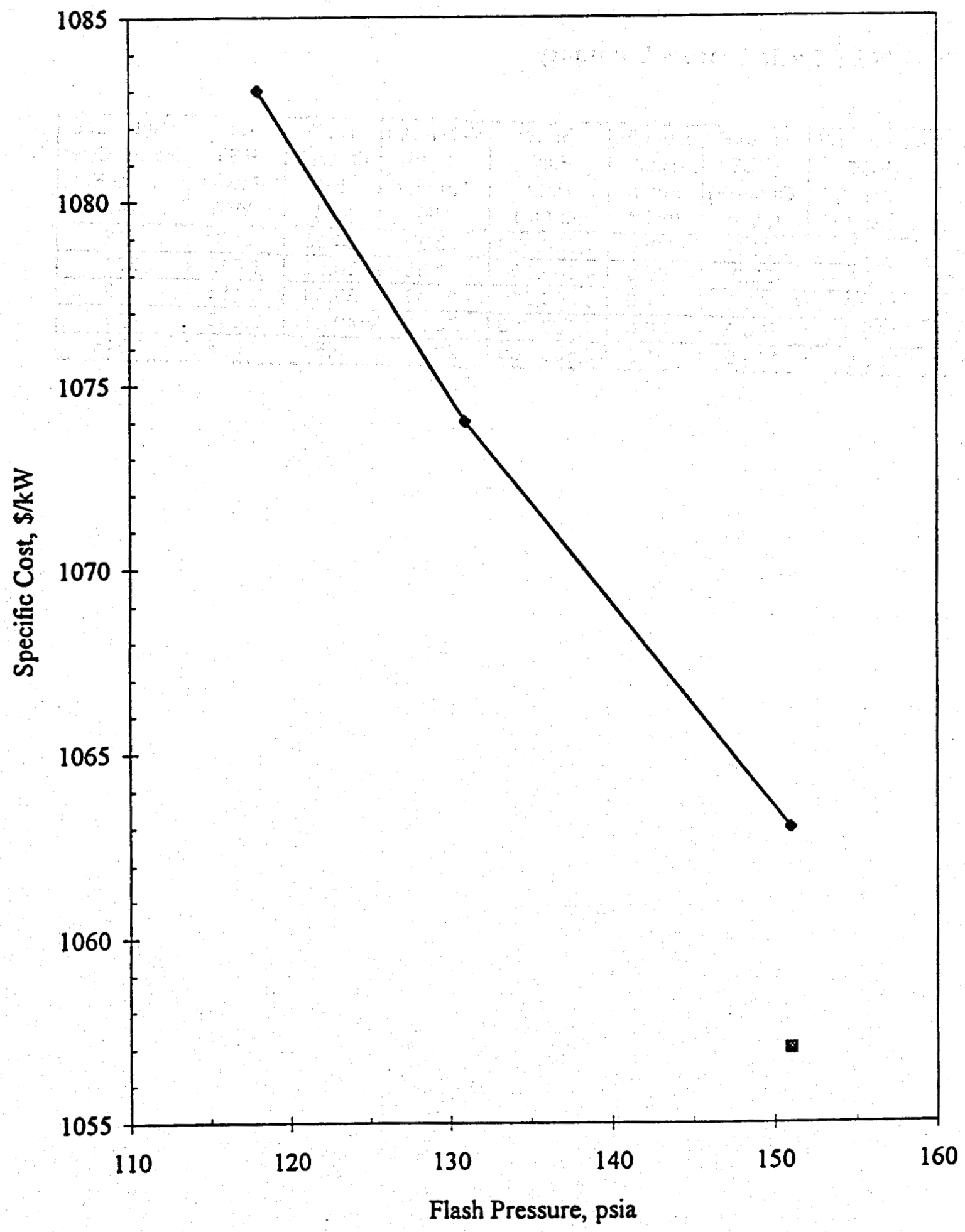

Figure 7-3

RST: Specific Capital Cost Vs. Flash Pressure, Salton Sea 
Table 7-1

Dual Flash/RST Cycle Process Summary

\begin{tabular}{|c|c|c|c|c|c|c|c|c|}
\hline Site & $\begin{array}{c}\text { Wellnead P } \\
\text { (RST } \\
\text { Inlet P) } \\
\text { (psia) }\end{array}$ & $\begin{array}{c}\text { Flash P } \\
\text { (RST } \\
\text { Outlet P) } \\
(\text { psia) }\end{array}$ & $\begin{array}{c}\text { Dual Figh } \\
\text { High } \\
\text { Flash } \\
(\text { psia) }\end{array}$ & $\begin{array}{c}\text { Erine } \\
\text { Flow } \\
\text { Rate } \\
(\mathrm{lb} / \mathrm{hr})\end{array}$ & $\begin{array}{c}\text { Wellhead } \\
\text { Steam } \\
\text { Quality } \\
(\%)\end{array}$ & $\begin{array}{c}\text { RST } \\
\text { Overall } \\
\text { Eff } \\
(\%)\end{array}$ & $\begin{array}{c}\text { Gross } \\
\text { RST } \\
\text { Power } \\
(\mathrm{kW})\end{array}$ & $\begin{array}{c}\text { Net Plant } \\
\text { Power Over } \\
\text { Oual FI } \\
(\mathrm{kW}\end{array}$ \\
\hline Desen Peak & 90.0 & 71.0 & 90.0 & 4.500 .000 & 12.30 & 26.50 & 883 & 242 \\
\hline Dixie Valley & 100.0 & 80.0 & 100.0 & 4.000 .000 & 14.65 & 30.59 & 1.032 & 331 \\
\hline Glass Mtn & 151.0 & 100.0 & 151.0 & 3.000 .000 & 19.43 & 39.68 & 2.456 & 572 \\
\hline Coso Hot Sp & 130.0 & 100.0 & 130.0 & 3.200 .000 & 22.69 & 40.46 & 2.000 & 418 \\
\hline Salton Sea & 325.0 & 118.0 & 151.0 & 2.600 .000 & 21.65 & 46.57 & 6.058 & 3.045 \\
\hline
\end{tabular}




\section{Dual Flash/Steam Reheater}

\section{Introduction}

A recent study has proposed the addition of a steam reheater to the dual flash process to improve cycle performance ( $\mathrm{Li}$ and Priddy, 1985). This concept involves using a steam reheater to superheat the exhaust from the high pressure turbine stages with the saturated liquid from the high pressure separator bottom. This technology has found some application in advanced nuclear power plants (Id.). A theoretical investigation of the use of a steam reheater for geothermal applications has been reported (DiPippo and Vrane, 1991). The authors concluded that addition of a steam reheater can yield from one to six percent more work compared to a conventional dual flash plant.

\section{Cycle Process Flow}

Figure 7-4 shows a process flow diagram for a dual flash/steam reheater geothermal power plant. The plant is a modification of a commercial dual flash plant. In a commercial dual flash plant, the stream from the bottom of the high pressure separator is flashed in a low pressure separator to generate low pressure stream. In a dual flash/steam reheater plant, the brine from the high pressure separator bottom is used to superheat the outlet from the high pressure turbine blades. This superheated steam is then mixed isobarically with the saturated steam from the low pressure separator. The combined stream is then sent to the low pressure turbine blades to produce the remainder of the power.

\section{Performance Analysis}

\section{Description}

The optimization approach used for the analysis of dual flash plants was also used for analyzing the performance of power plants based on dual flash/steam reheater technology. Thus, the optimization process involves calculating optimal values of condenser approach temperature, cooling water flow rate, etc.

\section{Assumptions}

Following three specific assumptions were used to analyze the performance of dual flash/steam reheater plants:

- The increased efficiency of the low pressure turbine section is accounted for using the Bauman rule (Bauman 1921). The efficiency of the low pressure turbine section in a commercial dual flash plant is $85 \%$. For dual flash/steam reheater plants the efficiency is increased by $1 \%$ (over the baseline value of $85 \%$ ) for every $2 \%$ reduction in the moisture content of the exhaust steam. 
- A 2 psi pressure drop is assumed for the steam side of the steam reheater.

- The minimum approach on the reheater is set at $5^{\circ} \mathrm{F}$.

\section{Cost Analysis}

\section{Description}

The basic cost model used to analyze commercial dual flash plants was modified to analyze dual flash/steam reheater plants to account for the cost of the steam reheater. Steam reheater duty and log mean temperature difference (LMTD) were calculated using the commercial process simulator HYSIM for given stream inlet conditions. A $5^{\circ} \mathrm{F}$ approach temperature was used in all calculations. An overall heat transfer coefficient of $40 \mathrm{Btu} / \mathrm{hr}-\mathrm{ft}^{2} \mathrm{~F}$, and a specific cost of $\$ 8.50$ per sq. $\mathrm{ft}$. of surface area were assumed.

\section{Results}

Figure 7-5 which plots the percent increase in specific output of plants with steam reheaters over conventional dual flash plants shows that for the colder resources, employing a steam reheater actually reduces brine utilization. This is due to the pressure drop in the reheater and associated piping which reduces the second law efficiency of the cycle. For the colder resources, this drop in second law efficiency offsets any gains in turbine efficiency that the steam reheater provides compared to the dual flash cycle. For Salton Sea and Glass Mountain, the steam reheater pressure drop is a smaller fraction of the total cycle pressure drop and the increase in blade efficiency is enough to overcome the decrease due to the pressure drop. Therefore there is a net increase in specific output.

Tables 7-2 and 7-3 summarize the peformance of the dual flash/steam reheater power plants for Surprise Valley, Desert Peak, Dixie Valley, Glass Mountain, and Salton Sea. Specific capital cost for the various sites are also presented in Table 7-3 along with the specific capital cost for dual flash power plants at the respective stes. It can be observed from Table 7-3 that the flash plants with steam teaheater have higher specific capital costs than conventional dual flash plants for all the sites listed in the table. Clearly, on an econonmic basis increased capital costs associated with the steam reheater do not justify the increased specific output that a steam reheater can provide. 


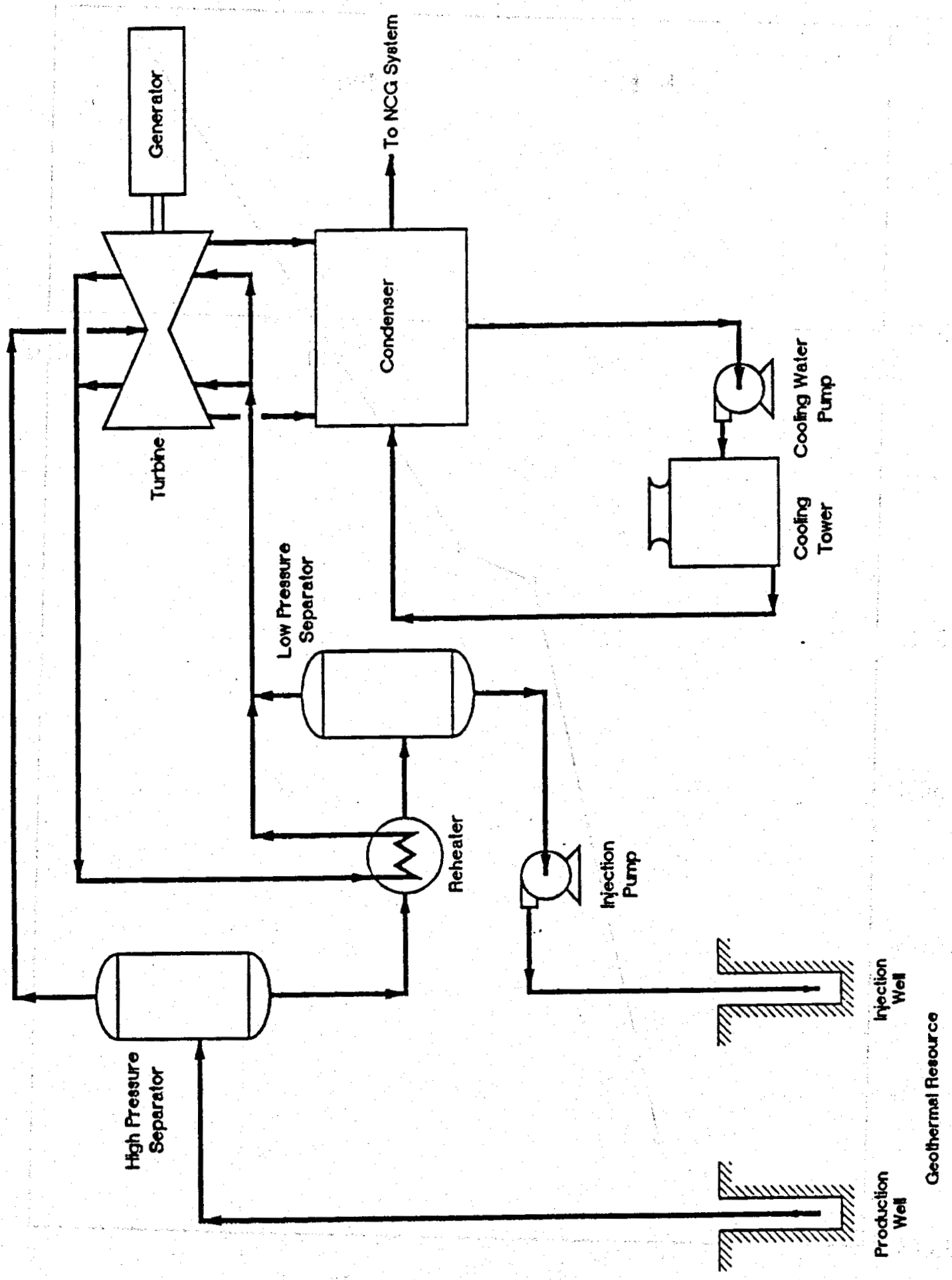

Figure 7-4

Dual Flash/Steam Reheater - Process Flow Diagram 


\section{Steam Reheater Brine Utilization}

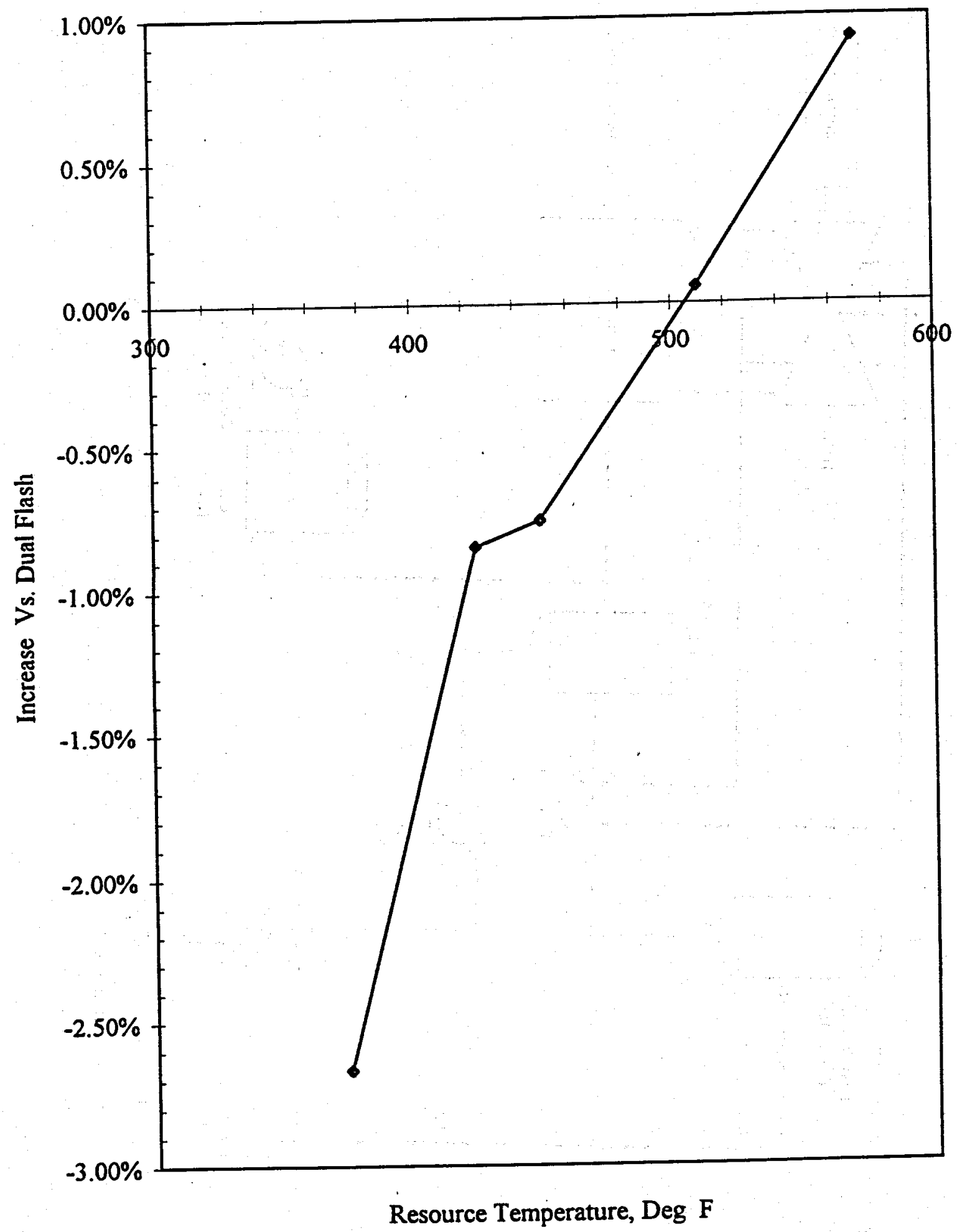

Figure 7-5

DFSR: Incremental Change in Specific Power Output 
Table 7-2

Dual Flash/Steam Reheater - Major Equipment Costs

\begin{tabular}{|c|c|c|c|c|c|c|c|c|c|c|c|c|c|c|c|}
\hline Site & $\begin{array}{l}\text { Res. } \\
\text { Temp } \\
\text { (F) }\end{array}$ & $\begin{array}{l}\text { High } \\
\text { Press } \\
\text { Steam } \\
(M \mathrm{lb} / \mathrm{hr}) \\
\end{array}$ & $\begin{array}{c}\text { Low } \\
\text { Press } \\
\text { Steam } \\
\text { (M lb/hr) } \\
\end{array}$ & $\begin{array}{l}\text { Turb in } \\
\text { Press } \\
\text { High } \\
\text { (psia) }\end{array}$ & $\begin{array}{c}\text { Turb in } \\
\text { Press } \\
\text { Low } \\
\text { (psia) } \\
\end{array}$ & $\begin{array}{l}\text { Cond } \\
\text { Press } \\
\text { (in } \mathrm{Hg} \text { ) }\end{array}$ & $\begin{array}{c}\text { High } \\
\text { Press } \\
\text { Blade } \\
\text { Eff. } \\
\end{array}$ & \begin{tabular}{|l} 
y Turb \\
Outlet \\
Sat \\
Steam
\end{tabular} & \begin{tabular}{|l|} 
y Turb \\
Outlet \\
Sup \\
Steam
\end{tabular} & $\begin{array}{c}\text { Low } \\
\text { Press } \\
\text { Blade } \\
\text { Eff. }\end{array}$ & \begin{tabular}{|c|} 
High P \\
Gross \\
Power \\
(kWy \\
\end{tabular} & $\begin{array}{l}\text { Low P } \\
\text { Gross } \\
\text { Power } \\
\text { (kW) }\end{array}$ & $\begin{array}{l}\text { Total } \\
\text { Gen } \\
\text { Output } \\
\text { (kW) }\end{array}$ & $\begin{array}{c}\text { Net } \\
\text { Plant } \\
\text { Output } \\
\text { (kW) }\end{array}$ & $\begin{array}{l}\text { Dual } \\
\text { Flash } \\
\text { Output } \\
\text { (kW) }\end{array}$ \\
\hline Surprise Valley & 375 & 663.0 & 485.0 & 51.5 & 12.41 & 2.06 & 0.83 & .9112 & .9270 & .8579 & 14,285 & 46,623 & 55.917 & 48.221 & 49,998 \\
\hline Desert Peak & 425 & 537.0 & 303.7 & 90.0 & 23.00 & 1.96 & 0.83 & .8885 & 9065 & .8590 & 12.265 & 43,437 & 50,495 & 47,560 & 47,946 \\
\hline Dixie Valley & 450 & 541.2 & 292.3 & 100.0 & 21.00 & 2.18 & 0.83 & .8946 & .8159 & .8607 & 14,134 & 40,869 & 50,331 & 47,521 & 47,902 \\
\hline Glass Mountain & 510 & 547.3 & 223.0 & 151.0 & 28.00 & 2.09 & 0.83 & .6833 & .9099 & .8633 & 16,051 & 42.488 & 54,148 & 51,347 & 51,339 \\
\hline Salton Sea & 570 & 559.2 & 128.4 & 151.0 & 28.00 & 2.03 & 0.83 & .8825 & 9128 & .8652 & 16,399 & 38.481 & 51,079 & 48.297 & 47.833 \\
\hline
\end{tabular}

Table 7-3

Hot Water Turbine Cycle - Major Equipment Costs

\begin{tabular}{|c|c|c|c|c|c|c|c|c|c|c|c|c|c|c|}
\hline Sile & $\begin{array}{c}\text { Sat Liq } \\
\text { Flow } \\
\text { Rate } \\
\text { (M lb/hr) }\end{array}$ & $\begin{array}{l}\text { Sat } \\
\text { Liq } \\
\text { Temp } \\
\text { (F) }\end{array}$ & $\begin{array}{c}\text { Turb } \\
\text { Exh } \\
\text { Flow } \\
(\mathrm{M} \text { lb/hr) }\end{array}$ & $\begin{array}{l}\text { Turb } \\
\text { Exh } \\
\text { Press } \\
\text { (psia) }\end{array}$ & $\begin{array}{c}\text { Turb } \\
\text { Exh } \\
y\end{array}$ & $\begin{array}{c}\text { Rhit } \\
\text { Appr } \\
\text { Temp } \\
\text { (F) }\end{array}$ & $\begin{array}{l}\text { Rhtr } \\
\text { Press } \\
\text { Drop } \\
\text { (psia) } \\
\end{array}$ & $\begin{array}{l}\text { Rhir } \\
\text { Duty } \\
\text { (MM } \\
\text { Btu/hr) } \\
\end{array}$ & $\begin{array}{c}\text { Rhit } \\
\text { LMTD } \\
\text { (F) } \\
\end{array}$ & $\begin{array}{c}\text { Rhtr } \\
\text { Area } \\
\text { (ft sq) } \\
\end{array}$ & $\begin{array}{c}\text { Rhtr } \\
U \\
\text { (Btu/hr } \\
\text { F ft sq) }\end{array}$ & 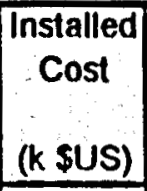 & $\begin{array}{c}\text { Spec } \\
\text { Plant } \\
\text { Cost } \\
(\$ / k W) \\
\end{array}$ & $\begin{array}{l}\text { Dual } \\
\text { Flash } \\
\text { cost } \\
(\$ / \mathrm{kW}) \\
\end{array}$ \\
\hline Surprise Valley & 6.641 & 285.5 & 663.0 & 15.41 & 0.949 & 5 & $\overline{2}$ & 53.72 & 40.30 & 33,325 & 40 & 716.6 & 2,325 & 2,242 \\
\hline Desen Peak & 3,949 & 322.0 & 537.0 & 26.00 & 0.944 & 5 & 2 & 48.84 & 42.84 & 28,500 & 40 & 612.9 & 1,511 & 1.491 \\
\hline Dixie Valley & 3,408 & 329.4 & 541.0 & 24.00 & 0.936 & 5 & 2 & 55.59 & 47.19 & 29,450 & 40 & 633.3 & 1,246 & 1,225 \\
\hline Glass Mountain & 2,415 & 360.1 & 547.0 & 31.00 & 0.925 & 5 & $\overline{2}$ & 64.79 & 51.60 & 31,372 & 40 & 674.7 & 1,514 & 1.504 \\
\hline Salton Sea & 2,011 & 360.1 & 559.0 & 31.00 & 0.925 & 5 & $\overline{2}$ & 66.68 & 50.30 & 33,140 & 40 & 712.7 & 1,069 & 1.057 \\
\hline
\end{tabular}




\section{Sub-atmospheric Flash}

\section{Introduction}

For the analysis of the baseline dual flash technology, the assumption is made that the low pressure flash pressure may not be below atmospheric pressure, in order to prevent any possible problems with air leakage into the system. This section analyzes the effect of relaxing this restriction: the resultant concept is called sub-atmospheric flash technology. It should be noted that the sub-atmospheric flash technology is only applicable to resources that have temperature below $400^{\circ} \mathrm{F}$ since the optimal low pressure flash pressure for resources with temperatures above $400^{\circ} \mathrm{F}$ is greater than one atmosphere.

\section{Cycle Process Flow}

Sub-atmospheric flash cycles have essentially the same process as a conventional dual flash cycle. The reader is referred to the dual flash section of this report for the process description. The process flow diagram is shown in Figure 7-6.

\section{Performance Analysis}

\section{Description}

Refer to the dual flash section for details on performance analysis of subatmospheric flash cycles.

\section{Assumptions}

The same assumptions that were used for dual flash cycles apply here.

\section{Cost Analysis}

\section{Description}

Once again the cost analysis methodology used in analyzing conventional dual flash plants was also used to analyze sub-atmospheric flash plants. In addition, the impact of sub-atmospheric turbine inlet pressures on turbine cost and performance was determined in consultation with Fuji Electric, one of the co-investigators on the project.

It appears that sub-atmoshpheric inlet pressures do not affect turbine cost per se. However, lowering flash pressures below atmospheric increases the volumetric flow rate of steam because both the mass flow rate and specific volume increase. In turn, the higher volumetric flow rate increases exhaust losses. Consequently, an economic optimum exists between the added cost of 
using an extra turbine and its potential to improve power production by lowering exhaust losses. It was found that for the cases at Surprise Valley and Vale, two 27 inch last stage blade length dual flow turbines are still the best choice. This is the same as for the baseline dual flash cases. However, for Raft River, the two and three turbine plants were found to have nearly the same specific plant cost. Preliminary investigations on the Thermo Hot Springs case indicated that optimum turbine configurations required four to five turbines. Therefore, this case was not pursued any further.

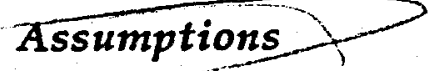

\section{Results}

\section{Performance}

Sub-atmospheric flash cycles were analyzed for three sites, Surprise Valley, Vale, and Raft River. Thermo Hot Springs with a resource temperature of $265^{\circ} \mathrm{F}$ was omitted because flash technology is unattractive at that low a resource temperature. Figure 7-7 plots the specific output for both conventional dual flash and sub-atmospheric flash power plants. It can be seen from the figure that, in general, specific output is higher for subatmospheric flash cycles compared to conventional dual flash cycles but the increase in specific output is not dramatic. It appears that the specific ouptut is fairly constant over a range of flash pressures.

\section{Economics}

Figure 7-8 compares the specific capital cost of the subatmospheric flash cycle with that of the conventional dual flash cycle. For Surprise Valley and Vale, the subatmospheric flash cycle is only slightly more economical than the conventional dual flash cycle. This is due to the fact that the brine utilization is only slightly better for these cases. For the case of Raft River, the subatmospheric flash cycle is about $\$ 80$ per kilowatt cheaper.

Although relaxing the restriction on the low pressure flash pressure leads to improvement over conventional dual flash technology, it does not make flash technology superior to binary technology at low resource temperatures. Binary technology still has better brine utilization and a lower capital cost per kilowatt. Clan

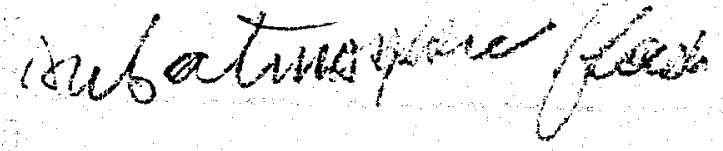<smiles>CCCCC1(CCC)CCCC1</smiles>

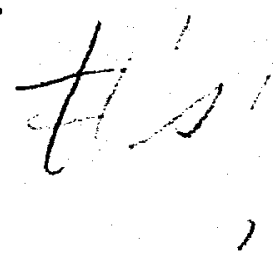




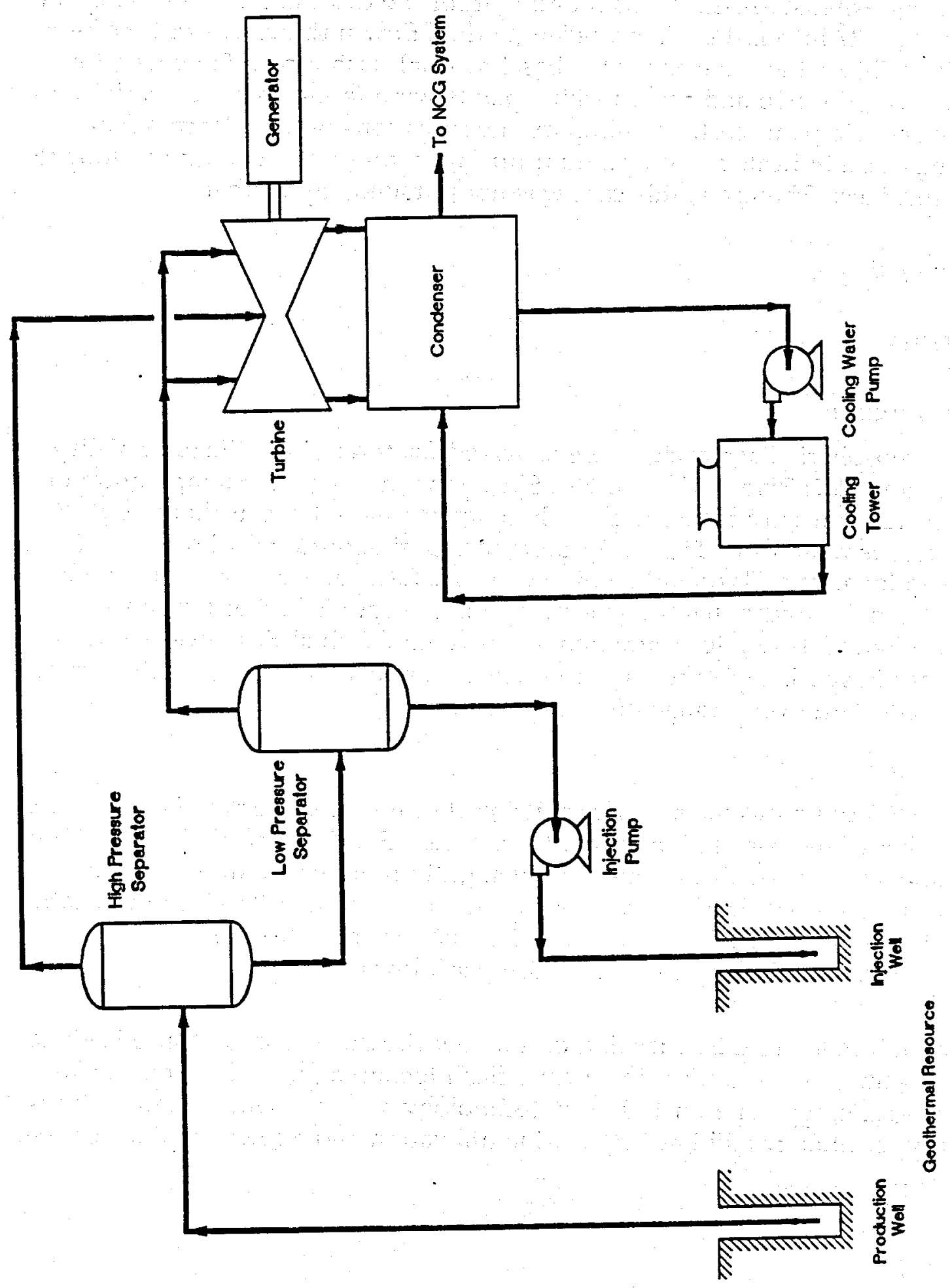

Figure 7-6

Sub-atmospheric Flash Cycle - Process Flow Diagram 


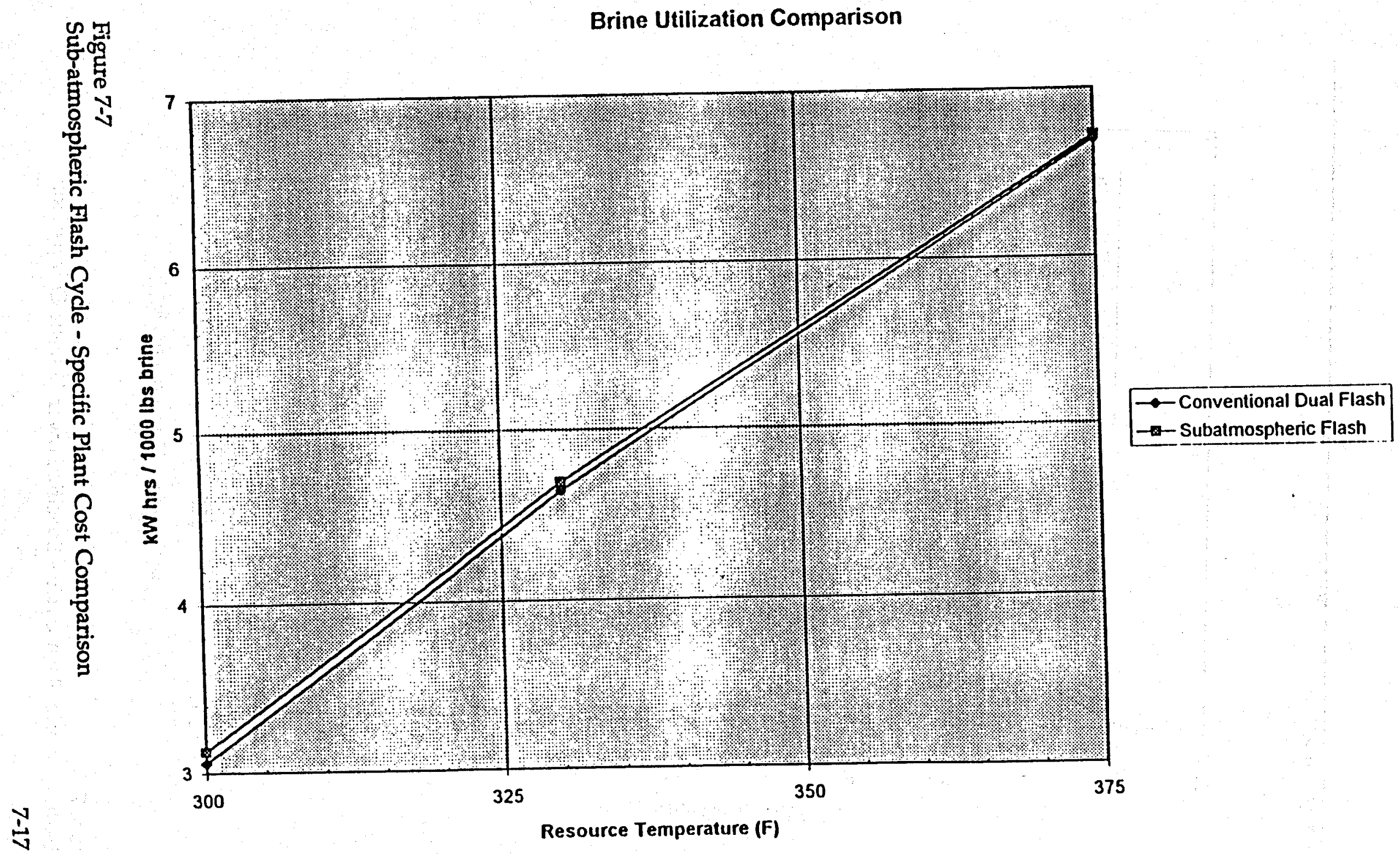




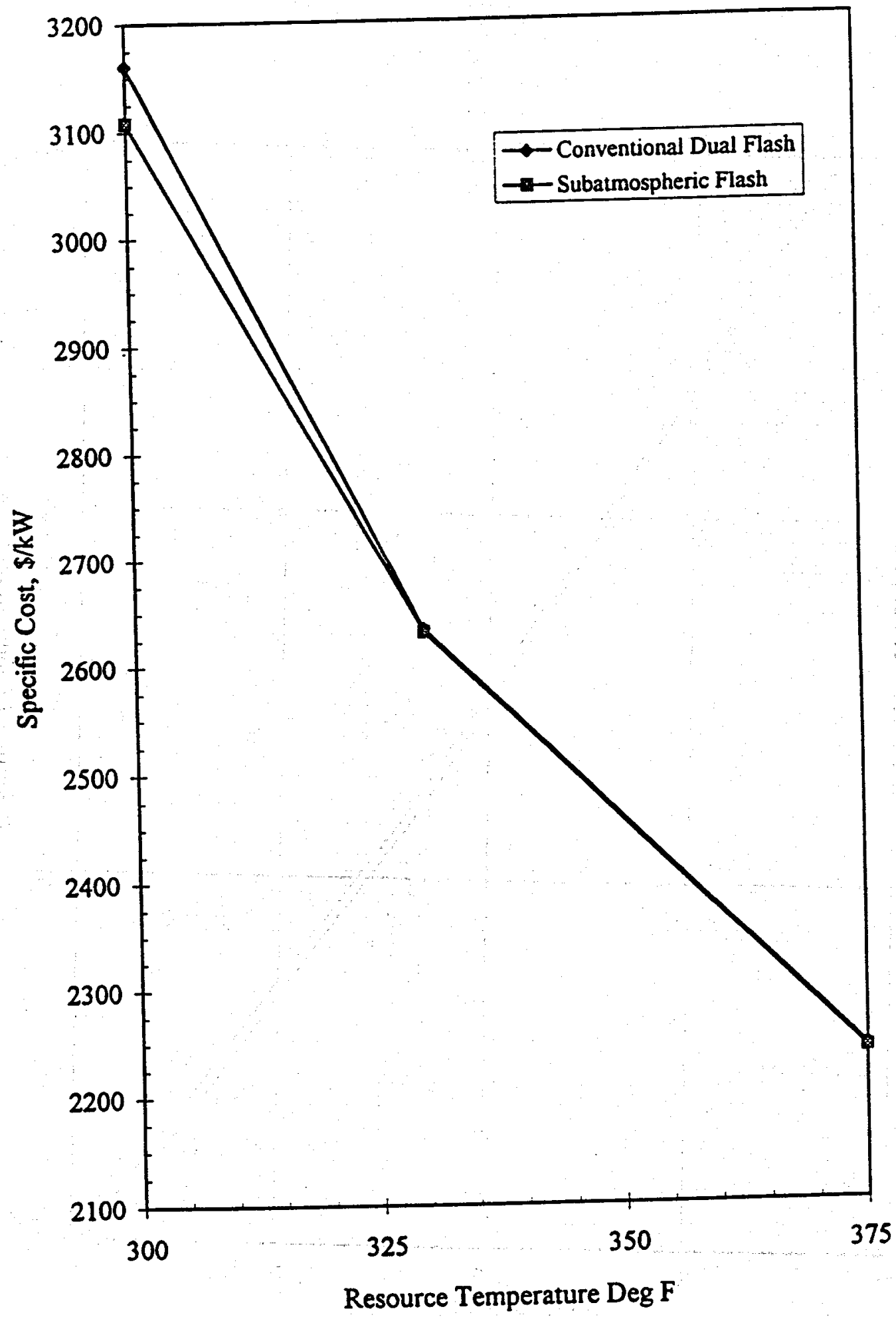

Figure 7-8

Sub-atmospheric Flash Cycle - Specific Power Output Comparison 


\section{Dual Flash/Hot Water Turbine}

\section{Introduction}

Hot water turbine technology attempts to utilize the available energy lost in the throttling process between the high and low pressure separators of a dual flash plant. It essentially involves adding a turbine that can use hot water to generate power, between the two separators.

\section{Cycle Process Flow}

Figure 7-9 contains a process flow diagram for the dual flash/hot water turbine cycle. The dual flash process is identical to that investigated in Section 5 of the report with the addition of the hot water turbine. The hot water turbine is employed in between the high and low pressure separators producing added gross plant power.

\section{Performance Analysis}

This technology was applied at just three of the NGGPP sites: Raft River, Dixie Valley, and Glass Mountain. These three sites were chosen to represent a cold, medium, and hot resource, respectively, since resource temperatures determine the difference between the high and low flash pressures. Thus, with these three resources it is possible to examine the effect of the increasing hot water turbine pressure drop on the thermodynamics and economics of the power plants.

\section{Description}

Hot water turbine technology was analyzed using a slightly modified form of the Holt models used for analyzing dual flash cycles. In order to model the performance of the hot water turbine, a dual flash cycle was simulated assuming the overall hot water turbine efficiency to be $40 \%$. Using the liquid flow rate and the inlet and outlet pressures from these calculations, the hot water turbine was then designed by Fuji Electric Co. and the overall hot water turbine efficiency calculated. Overall efficiency calculated by Fuji was input into the dual flash model and the final net plant output found.

\section{Assumptions}

The assumptions for the dual flash process are consistent with the conventional dual flash analysis (see Section 5). A 93\% mechanical efficiency was assumed for the hot water turbine to account for generator, gear and bearing losses. 


\section{Cost Analysis}

\section{Description}

Along with the turbine design, Fuji also provides detailed cost estimates for production of the hot water turbine. The cost of the hot water turbine is added to the dual flash cost model to calculate the entire dual flash/hot water turbine plant cost.

\section{Assumptions}

The installed cost multiplier for the hot water turbine is 1.8 ; other assumptions are the same as those used to evaluate dual flash technology.

\section{Results}

\section{Performance}

Table 7-4 is a summary of each of the dual flash/hot water turbine cases. Several items are noteworthy. First, the initial estimate of forty percent efficiency for the hot water turbine was close to the final calculated value. Table 7-4 shows that the hot water turbine appears to perform more efficiently at Dixie Valley than at Glass Mountain. This is due to the fact that a standard turbine was used for all the sites; within the scope of this study turbine designs were not tailor-made for the various sites.

It was found that specific output can be maximized by lowering the low pressure flash pressure below the optimum found in the dual flash cases because allowing the hot water turbine to produce power over a larger pressure drop is thermodynamically favorable. At some point, however, the flash pressures become too low reducing the performance of the steam turbine.

Figure 7-10 compares the specific output of dual flash technology with and without the hot water turbine. As expected, the hot water turbine improves the specific output, and the improvement in specific output is greater for the hotter resources.

\section{Economics}

Major equipment costs for the dual flash/hot water turbine plant are summarized in Table 7-5. The cost of the hot water turbine divided by its gross power production for Glass Mountain and Dixie Valley is roughly $\$ 1530 / \mathrm{kW}$, and $\$ 8000 / \mathrm{kW}$ for Raft River. These turbine costs alone are higher than the specific capital cost for conventional dual flash technology. In addition, to some extent the hot water turbine produces power at the expense of the steam turbine, and thus the effect of using hot water turbines on specific capital cost is even greater. Figure 7-11 compares the specific capital 
cost of dual flash technology with and without a hot water turbine. As indicated earlier, specific capital cost of a dual flash plant with a hot water turbine is higher than that of a conventional dual flash plant. 

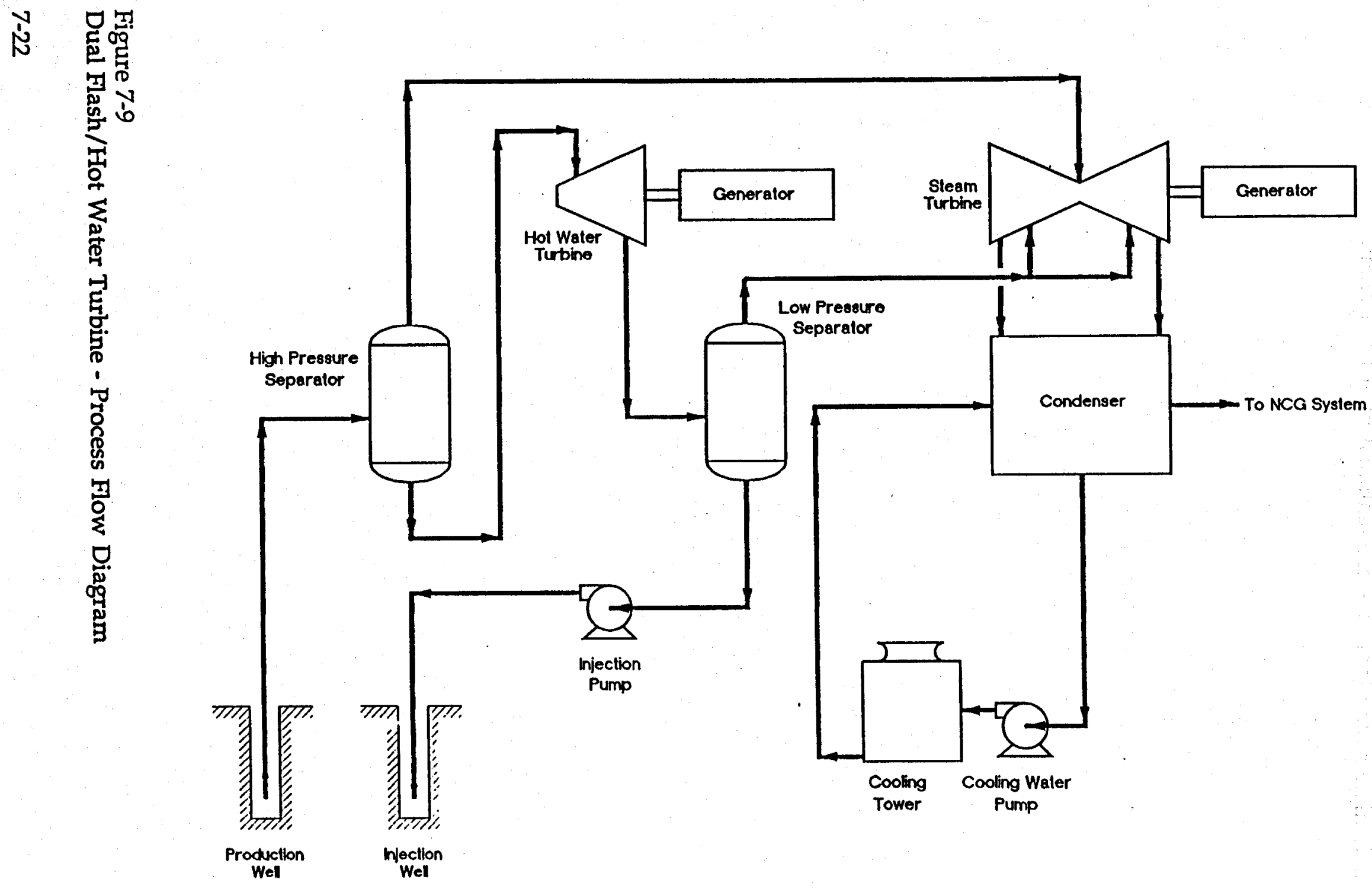

Goothermal Resource

C 

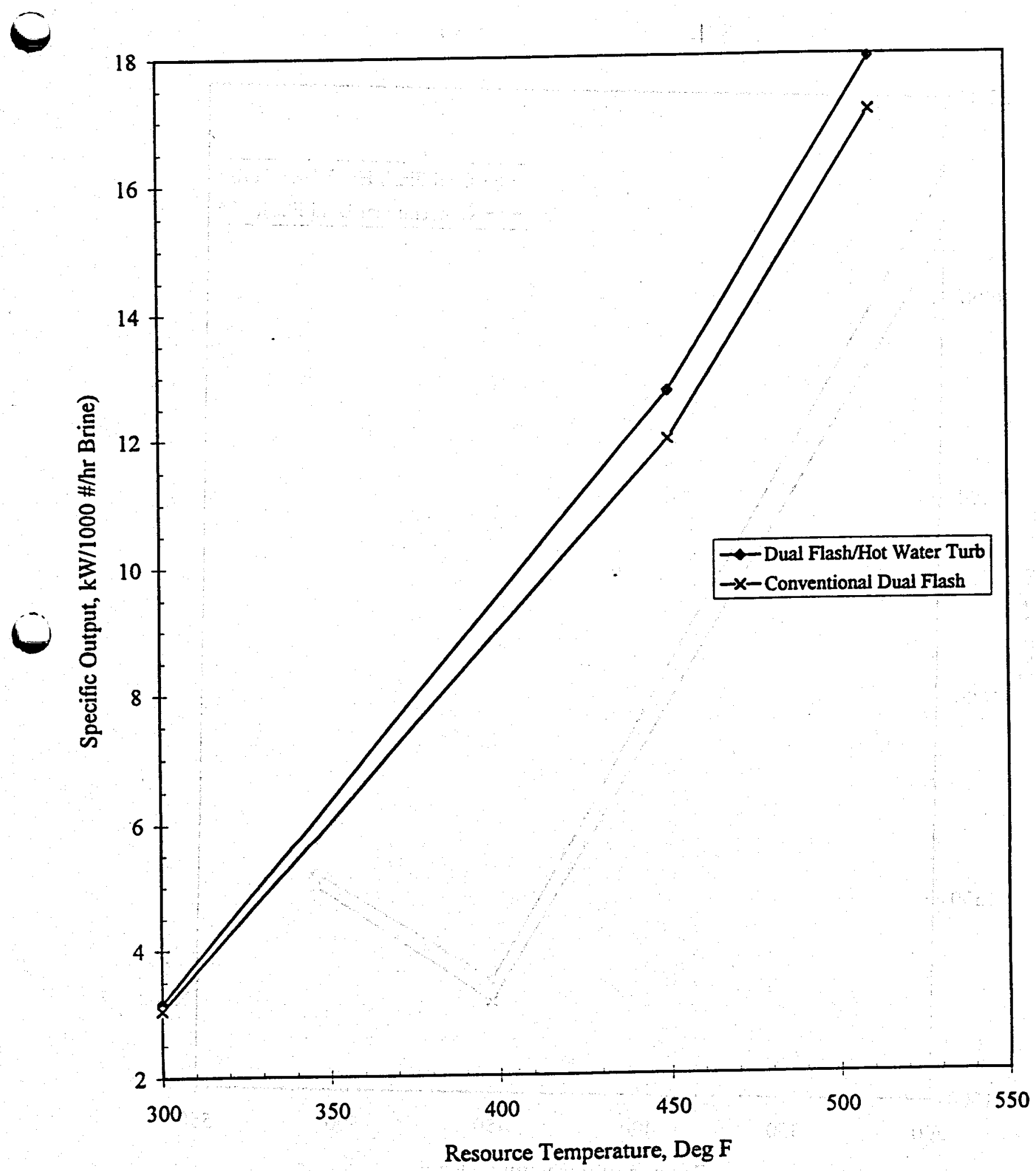

Figure 7-10

Brine Utilization Comparison 


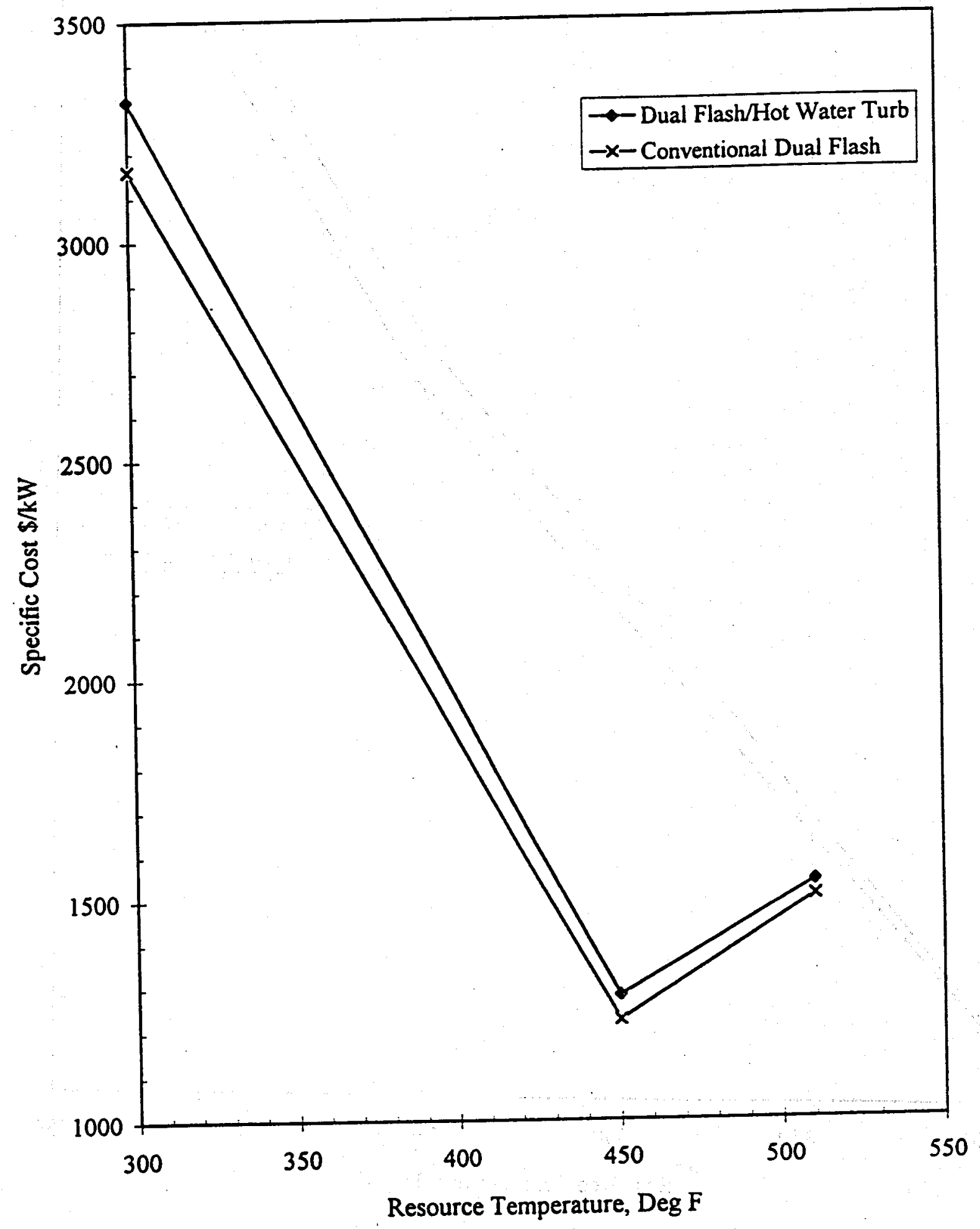

Figure 7-11

Specific Plant Cost Comparison 
Table 7-4

Dual Flash/Hot Water Turbine Case Summaries

\begin{tabular}{|c|c|c|c|}
\hline & Givss 10 . & DH & Rat/ $/$ aw \\
\hline High P Flash (psia) & 153.20 & 102.20 & 30.40 \\
\hline Low P Flash (psia) & 18.00 & 15.00 & 13.45 \\
\hline Cond P (" Hg) & 2.16 & 2.24 & 1.78 \\
\hline Brine Flow (lb/hr) & $3,000,000$ & $4,000,000$ & $15,391,851$ \\
\hline High P Steam (lb/hr) & 579,721 & 584,211 & 734,371 \\
\hline Low P Steam (lb/hr) & 340,159 & 402,132 & 653,729 \\
\hline Hot Water Turb Eff. & 0.41 & 0.46 & 0.38 \\
\hline Hot Water Turb Power (kW) & 3.540 & 4,060 & 2,110 \\
\hline Steam Turb Power (kW) & 53,230 & 49,280 & 60,224 \\
\hline Plant Net Power (kW) & 53,865 & 50,953 & 48,685 \\
\hline
\end{tabular}


Table 7-5

Dual Flash/Hot Water Turbine Plant Capital Costs

\begin{tabular}{|c|c|c|c|c|}
\hline \multirow[t]{7}{*}{ Power } & Plant & $\begin{array}{l}\text { Dixie Valley } \\
450^{\circ} \mathrm{F}\end{array}$ & $\begin{array}{l}\text { Raft River } \\
300^{\circ} \mathrm{F}\end{array}$ & $\begin{array}{l}\text { Glass Mtn } \\
510^{\circ} \mathrm{F}\end{array}$ \\
\hline & H.P. Separators & 135,600 & 480,000 & 101,248 \\
\hline & L.P. Separators & 247,500 & 495,000 & 210,000 \\
\hline & Purifiers & 49,600 & 132,800 & 53,000 \\
\hline & Silencers & 22,500 & 22,500 & 22,500 \\
\hline & Condenser & $1,675,900$ & $2,147,600$ & $1,595,300$ \\
\hline & Hot Well/Cond. Pumps & 879,500 & $1,358,800$ & 891,400 \\
\hline & Fire Pụmps & 55,000 & 55,000 & 55,000 \\
\hline & L. O. Trans. Pumps & 4,000 & 4,000 & 4,000 \\
\hline & Pot. Water Pumps & 7,000 & 7,000 & 7,000 \\
\hline & Aux. C.W. Pumps & 42,700 & 53,200 & 40,600 \\
\hline & Injection Pumps & 93,100 & 334,900 & 74,600 \\
\hline & Cooling Tower & $1,265,200$ & $2,387,200$ & $1,289,100$ \\
\hline & Plant Air System & 116,600 & 115,800 & 125,100 \\
\hline & L. O. Storage Tanks & 29,000 & 29,000 & 29,000 \\
\hline & Turbine Generator & $11,559,000$ & $19,634,000$ & $11,773,000$ \\
\hline & NCG Removal & 81,100 & $1,431,900$ & 75,000 \\
\hline & Gantry Crane & 500,000 & 500,000 & 500,000 \\
\hline & Vac Hot Well & 15,100 & 15,100 & 15,100 \\
\hline & Sulfur Plant & 549,000 & 0 & $1,219,000$ \\
\hline & Misc. Tanks & 157,000 & 268,000 & 158,000 \\
\hline & Start-up or Emer Gen. & 31,000 & 31,000 & 31,000 \\
\hline & FW Tank + Sys & 169,875 & 320,513 & 173,075 \\
\hline & Total Major Equipment & $18,251,466$ & $30,796,903$ & $19,012,863$ \\
\hline & Total Plant Cost & $46,176,000$ & $77,916,000$ & $48,103,000$ \\
\hline \multicolumn{5}{|c|}{ Gathering \& Injectlon System } \\
\hline & Production Pumps & 0 & 3,123, & 0 \\
\hline & Prod. Pump Aux. & 0 & 158,400 & \\
\hline & Silencers & 25,000 & 25,000 & 25,000 \\
\hline & Total Major Equipment & 25,000 & $3,306,695$ & 25,000 \\
\hline & Total & 53,000 & $6,977,000$ & 53,000 \\
\hline & mary & & & \\
\hline \multirow{2}{*}{\multicolumn{2}{|c|}{$\begin{array}{l}\text { Plant Equip. Cost } \\
\text { Total Plant Equip Cost }\end{array}$}} & Dixie Valley & Raft River & Glass Mtn \\
\hline & & $\begin{array}{l}18,251,466 \\
46,176,000\end{array}$ & $\begin{array}{l}30,796,903 \\
77,916,000\end{array}$ & $\begin{array}{l}19,012,863 \\
48,103,000\end{array}$ \\
\hline \multicolumn{2}{|c|}{$\begin{array}{l}\text { Gath \& Injec Equip Cost } \\
\text { Total Gath \& Injec Equip Cost }\end{array}$} & $\begin{array}{l}25,000 \\
53,000\end{array}$ & $\begin{array}{l}3,306,695 \\
6,977,000\end{array}$ & $\begin{array}{l}25,000 \\
53,000\end{array}$ \\
\hline \multicolumn{2}{|c|}{ Hot Water Turbine Cost } & $6,300,000$ & $17,496,000$ & $5,400,000$ \\
\hline \multicolumn{2}{|c|}{ Gath \& Injec Piping Cost } & $1,112,000$ & $1,402,000$ & $1,754,000$ \\
\hline \multicolumn{2}{|c|}{ Well Cost } & $11,571,429$ & $57,750,000$ & $27,500,000$ \\
\hline \multirow{2}{*}{\multicolumn{2}{|c|}{$\begin{array}{l}\text { Grand Total } \\
\text { Speclfic Plant }\end{array}$}} & $65,212,429$ & $161,541,000$ & $82,810,000$ \\
\hline & & 1,280 & 3,318 & 1,537 \\
\hline
\end{tabular}




\section{8}

\section{KALINA CYCLES}

\section{Kalina Cycle System 11}

\section{Introduction}

The Kalina cycle derives its name from its inventor, Dr. Alexander Kalina of Exergy, Inc. Its distinguishing features are the use of ammonia-water as a working fluid, and heat recuperation. With these two features, in a sense, the Kalina cycle brings together two ideas that have been separately considered by other authors.

The use of ammonia as a working fluid has been exhaustively studied (Milora and Tester, 1976). It was concluded that compounds with simple molecular structure, like ammonia, tend to lose superheat during turbine expansion. These compounds tend to yield a better thermodynamic performance "in subcritical Rankine-cycle configurations" than compounds like isobutane which have a complex molecular structure. Thus, it was found that at resource temperatures below about $300^{\circ} \mathrm{F}$, ammonia has a slightly superior performance compared to other working fluids. In the moderate temperature range, however, compounds like isobutane show a sharp increase in thermodynamic efficiency signifying a rapid transition to supercritical operation. In the 310 to $450^{\circ} \mathrm{F}$ range Rankine cycles with isobutane have sharply higher thermodynamic performance compared to ammonia. (Milora and Tester, 1976).

Heat recuperation has been implemented in previous designs. Heat recuperation was achieved at Magma's East Mesa plant by using two working fluids and two turbine generator sets (Hinrich's and Falk, 1977). However, the idea has not found wide acceptance and the industry appears to have opted for cycles "usually with no heat recuperation" (Ben Holt, 1980).

Exergy, Inc. has been at the forefront of Kalina cycle developments. Exergy was instrumental in the development of a Department of Energy funded demonstration plant at Canoga Park, California, in 1990. Exergy also has plans to build a geothermal power plant at Steamboat Springs, Nevada, again with Department of Energy support. As of the writing of this report, the Kalina cycle has not been demonstrated in any commercial geothermal power plant. 
The Kalina cycle encompasses a family of designs that change with temperature and application (Kalina and Leibowitz, 1989). This study considers two of these designs: Kalina cycle system 11 (KCS11) for resources below $400^{\circ} \mathrm{F}$, and Kalina cycle system 13 (KCS13) for resources above $400^{\circ} \mathrm{F}$.

\section{Cycle Process Flow}

Figure 8-1 is a process schematic of KCS11. The working fluid from the condenser (HE-1) flows through a pump to the recuperative liquid preheater (HE-2). The working fluid leaves the preheater at its bubble point and splits into two parallel streams. One stream enters the brine vaporizer (HE-3), while the other enters the recuperative vaporizer $(\mathrm{HE}-4)$. The partially vaporized streams leaving these exchangers mix together and flow to the second brine vaporizer (HE-5) for complete vaporization and superheating, if any. Saturated or slightly superheated working fluid vapor from HE-5 enters an axial turbine where it expands from about 350 psia to about 100 psia. The exhaust vapor from the turbine condenses in the recuperative vaporizer (HE4). The process of condensation continues through HE-2, and is completed in $\mathrm{HE}-1$, the condenser.

\section{Performance Analysis}

\section{Description}

The overall methodology for studying the Kalina cycles has involved developing cost and performance models. The basic performance model for the Kalina cycles is implemented using HYSIM which is a commercial process simulator. The model uses the PRSV thermodynamics package which is based on Vera's modification of the Peng-Robinson equation of state. The PRSV method is the vendor recommended method.

Two independent approaches were used to check the efficacy of the performance model. In the first approach, the cycle state points predicted by HYSIM were compared with those available from Exergy, Inc for the same cycle. Figure 8-2 presents Exergy's cycle state points for Kalina cycle system 11 along with cycle state points predicted by HYSIM for the same cycle. The figure shows that HYSIM cycle data match Exergy's data. The maximum deviation between any two corresponding state points is less than $5 \%$.

In the second approach, to further corroborate the accuracy of the models used in this study, HYSIM calculations have been verified using experimental data. In this approach, the state enthalpies predicted by the HYSIM model have been checked against experimental enthalpy data on the ammonia-water system from Institute of Gas Technology, Chicago (IGT Research Bulletin 34, 1969). The results of this check show that enthalpy values predicted by HYSIM are within $5 \%$ of the experimental enthalpy values from IGT. 
The HYSIM model for KCS11 is explained in what follows using the KCS11 process flow diagram (Figure 8-1). Much of the discussion of the KCS11 model will also apply to the KCS13 model.

For any given resource, model calculations are initiated by setting the ammonia concentration of the aqua-ammonia working fluid. For the chosen working fluid composition the following model inputs are specified:

- Preheater outlet is set at the bubble point

- Brine flow rate and re-injection temperature

- The first brine evaporator cold side approach

- Aqua-ammonia outlet temperature of $\mathrm{HE}-3$ and $\mathrm{HE}-4$ are equal.

With these specifications simulations of KCS11 are carried out by manipulating the aqua-ammonia flow rate and the temperature and flow rate of the aqua ammonia from HE-3 to control the following variables at desired values:

- Recuperator-evaporator cold side approach

- Recuperator-evaporator hot side approach

- Final evaporator hot side approach

When the desired results are obtained, a new ammonia concentration is chosen and the model calculations repeated. These calculations are repeated to cover a range of ammonia concentrations.

In the interest of clarity, the specific and general assumptions used in modeling KCS11 are listed in the following section.

\section{Assumptions}

The basic resource data is contained in Tables 4-1 to 4-4. These tables are used to obtain the following data for each resource:

- $\quad$ Average dry bulb temperature

- Composition of non-condensable gases in the geothermal brine

- $\quad$ Site altitude

- Geothermal fluid temperature

- Minimum reinjection temperature

- $\quad$ Average well flow rates

- Average well cost

- Probability of a dry hole

- Maximum flash pressure

In addition, a number of assumption were made to evaluate the performance of the Kalina cycles, and these are discussed below. To a siginificant extent these assumptions resulted in the evaluation of the Kalina cycle as an idealized cycle. In contrast, for the majority of other technologies cycle 
performance has been corrected for siginificant non-idealities using Holt's design and operating experience.

- In the absence of operating data, addtional pressure drop due to noncondensable gases was not added to increase the turbine backpressure for Kalina cycles. Were the correction for the presence of noncondensable gases to be made, Kalina cycle performance would be adversely affected. According to Holt experience noncondensable gases inevitably appear in the working fluid cycle, and cannot be eliminated with purge systems. Apparently, Exergy has also observed the presence of noncondensable gases in the Canoga Park demonstration plant but has not quantified the effect of these gases. In this study, the performance of other technologies was penalized by increasing the backpressure on the turbine by 3 psi to account for the presence of noncondensable gases in the working fluid.

- A critical assumption regarding the performance of the air cooled condenser was made for both KCS11 and KCS13: it was assumed that heat transfer equipment could be sized using ideal heating and cooling curves. A qualitative consideration of fundamental principles reveals that this heat transfer equipment performance may not be achievable in Kalina cycles, as discussed below.

The Kalina cycles use a multi-component mixture, aqua-ammonia, as the working fluid. The multi-component nature of the working fluid requires that if ideal heating and cooling curves are used to design heat transfer equipment, continuous equilibrium must be maintained between the vapor and liquid phases during any phase change operation. Of course, a prerequisite for equilibrium between phases is that the two phases be in intimate contact and not be segregated from each other. Given the configuration and stream conditions (for example quality) of the Kalina cycles, it appears that intimate contact between the liquid and vapor phase would be difficult to realize in practice.

As an illustration, consider the air-cooled condenser. The inlet stream to the air condenser in a typical Kalina cycle would be a two phase stream with about $35 \%$ liquid. Clearly, for ideal multi-component condensation to occur, vapor and liquid phases must remain in intimate contact throughout the condenser. However, vapor-liquid phases will segregate in the proposed condenser which, based on information supplied by Exergy, is a four pass unit with six rows of tubes. The first two passes of the condenser each have two parallel rows of tubes. In such an exchanger the liquid will flow through the lowest tubes and the vapor would flow through the upper tubes. Therefore, vapor-liquid equilibrium will not be obtained in the condenser 
resulting in an increase of as much as 20 to 25 psi in the turbine backpressure. The increased backpressure in turn will undermine turbine performance significantly. An alternative condenser design using 6 passes will improve vapor-liquid contact but would be more expensive than the proposed design. Moreover, even the 6 pass design will not completely eliminate segregation. More importantly the 6 pass design would increase pressure drop though the condenser by about five times compared to the 4 pass design and thus erode most of the potential performance improvements that it could provide.

- The pressure drop on the aqua-ammonia side for each exchanger has been kept the same for all cases and for all resources. Heat exchanger pressure drops are listed in Table 8-1.

- For the purpose of this study the overall efficiency for the turbinegenerator system is defined as the ratio of the generator output to the turbine adiabatic enthalpy drop. For all KCS11 cases the overall efficiency is kept constant at 0.815 . This value of the overall efficiency has been obtained from the aqua-ammonia turbine data supplied by Fuji Electric Company. In familiar terms, this value of the overall efficiency can be calculated by making the following adjustments to the internal efficiency:

- Subtract exhaust losses equivalent to $1.5 \mathrm{Btu} / \mathrm{lb}$ from the turbine enthalpy drop. The value of $1.5 \mathrm{Btu} / \mathrm{lb}$ was based on literature data (Cotton, 1993).

- Adjust internal efficiency for $4 \%$ pressure drop in the governor valve

- Generator mechanical efficiency of 0.975

The above adjustments have the effect of turning an internal efficiency of $88-90 \%$ to an overall efficiency of $81.5 \%$.

- The air-cooler approach temperature is kept constant at $20^{\circ} \mathrm{F}$ for all cases, and for all geothermal sites.

- The outlet of the preheater, HE-2 is fixed at the bubble point of the aqua-ammonia working fluid.

- Both KCS11 and KCS13 were simulated using HYSIM (V 2.50). The accuracy of the thermodynamic package that was chosen (Vera's modification of Peng-Robinson) was checked against thermodynamic data on the aqua-ammonia system published by The Institute of Gas Technology ( "Physical and Thermodynamic Properties of Ammonia- 
Water Mixtures", Research Bulletin No. 34, Institute of Gas Technology, September 1964).

- Exchanger HE-4 was proposed as a vertical exchanger with vaporization occurring inside straight vertical tubes as the liquid moves upward while condensing vapor falls downward through the shell (Leibowitz, 1994). This study used the industry-standard shell and tube exchangers for all exchangers except for HE-4 for designing Kalina cycle system 11 power plants.

\section{Cost Analysis}

\section{Description}

Three spreadsheet templates were used to obtain the plant cost for the Kalina cycles.

- Gathering/injection system cost spreadsheet

- Well pump spreadsheet

- Plant cost spreadsheet

For a discussion of the first two spreadsheets the reader is referred to Appendix A. The last spreadsheet was used to calculate the cost of a $50 \mathrm{MW}$ net power plant. The major components of this spreadsheet are as follows:

- Heat exchangers, including air-cooled condenser: These costs are based on overall heat transfer coefficients and cost per unit area supplied by a reputed TEMA-certified heat exchanger vendor.

- Turbine-generator set: These costs were supplied by Fuji Electric Company.

- Wellfield: The wellfield cost was calculated using well costs provded by EPRI and listed in Table 4-1. The number of producer wells was adjusted for the probability of finding dry holes.

- $\quad$ Plant parasitics: The parasitic loads are discussed in Appendix A. The following parasitics are calculated in the plant cost spreadsheet:

- Well pumping

- Air-cooler fan power

- Aqua-ammonia pumping

- Injection pumping

- Miscellaneous

Clearly the parasitic loads are a function of the generated power. For example, the air-cooler fan power is a function of the condenser duty which in turn is dependent on the generated power. Consequently, the process of sizing a 
$50 \mathrm{MW}$ net power plant is iterative. The required iterations were also performed in the plant cost spreadsheet.

The plant cost spreadsheet calculates both the specific power output $(\mathrm{kW} / \mathrm{Mlb} / \mathrm{hr})$ and the specific plant cost $(\$ / \mathrm{kW})$. Both numbers are calculated for a power plant designed to produce $50 \mathrm{MW}$ net.

\section{Assumptions}

- The cost per unit area and the overall heat transfer coefficient for the KCS11 heat exchangers are listed in Table 8-3.

- The overall heat transfer coefficients for the brine exchangers are adjusted for potential fouling according to the formula provided in Appendix A.

- The general assumptions related to calculation of parasitic loads are discussed in Appendix A.

\section{Results}

With the results of the performance model, plant cost for each ammonia concentration was determined using the cost model. Thus, data on plant cost as a function of ammonia concentration were obtained for each site: Thermo Hot Springs, Raft River, Vale, and Surprise Valley (only sites used for KCS11). A summary of the optimization results for KCS11 is shown on Figure 8-3 for the above four sites. Two general inferences that can be drawn from this figure are worth noting:

- As the resource temperature increases, the optimum plant design shifts towards lower ammonia concentrations.

- The optimization curve is steep for cold resources and relatively flat for hot resources.

Using the power plant design corresponding to the optimum ammonia concentration, specific output and specific capital cost were calculated for power plants at the four sites that KCS11 was applied to. These results are summarized in Table 8-3. To obtain a relative assessment of KCS11 at the various sites, specific output and capital cost for four cycles - KCS11, commercial binary cycle, mixed fluids binary (hydrocarbons), and mixed fluids binary (aqua-ammonia) - are plotted on Figure 8-4 and 8-5, respectively. The following broad conclusion can be inferred from the figures:

- Kalina cycle system 11 has a higher specific power output than the commercial binary cycle for Raft River and Thermo Hot Springs.

For Thermo Hot Springs and Raft River, the two coldest resources, the specific capital cost for KCS11 is lower than that for the commercial 
binary cycles. The lower cost for KCS11 for these two cold resources stems largely from better brine utilization (measured in $\mathrm{kW} / \mathrm{Mlb} / \mathrm{hr}$ ). The lowest cost cycle for Thermo Hot Springs has a $7 \%$ higher brine utilization than the lowest cost commercial binary cycle for the same resource. Similarly, the lowest cost KCS11 cycle for Raft River has a 17 $\%$ higher brine utilization than the lowest cost commercial binary cycle for the same resource. The higher brine utilization has two important implications for the overall cost : (I) lower air-cooler duty for fixed total power and (II) lower wellfield cost.

- For Thermo Hot Springs and Raft River, the specific capital cost for KCS11 is also somewhat lower than that for the optimum mixed fluids (hydrocarbon) cycle. However, at Thermo Hot Springs the mixed fluids (aqua-ammonia) cycle has a lower specific capital cost than KCS11, and is the lowest specific capital cost cycle for that site.

- The net cost per $\mathrm{kW}$ for KCS11 is almost equal to that for commercial binary for Surprise Valley, the hottest resource although the commercial binary cycle has an almost $10 \%$ better brine utilization than KCS11. This result can be ascribed to lower equipment cost originating in the significantly lower operating pressure for KCS11 compared to commercial binary cycles. Thus, lower equipment costs for KCS11 compensate for its lower brine utilization.

- For Vale, Oregon the commercial binary cycle demonstrates better performance than KCS11 both from the point of view of brine utilization and cost per $\mathrm{kW}$. The optimum commercial binary cycle has a $6.8 \%$ higher brine utilization, and a $5.6 \%$ lower cost than KCS11. 
Table 8-1

Aqua-ammonia Side Heat Exchanger Pressure Drops

\begin{tabular}{|c|c|c|}
\hline Exchanger & $\begin{array}{c}\text { Pressure Drop } \\
\text { KCS11 }\end{array}$ & $\begin{array}{c}\text { Pressure Drop } \\
\text { KCS13 }\end{array}$ \\
\hline & $(\mathrm{psi})$ & (psi) \\
\hline HE-1 & 4.3 & 0.3 \\
\hline HE-2 & $0.3 / 10.0$ & $0.3 / 15$ \\
\hline HE-3 & 10 & $0.3 / 2.0$ \\
\hline HE-4 & $1.0 / 10.0$ & 2.0 \\
\hline HE-5. & 10.0 & 2.0 \\
\hline HE-6 & & 2.0 \\
\hline HE-7 & & 2.0 \\
\hline HE-8 & & 2.0 \\
\hline HE-9 & & 2.0 \\
\hline
\end{tabular}


Table 8-2

Heat Exchanger Vendor Data

\begin{tabular}{|c|c|c|c|c|c|}
\hline Exchanger & Service & Tube Type & Overall U & $\begin{array}{c}\text { Cost } \\
(\$ / \text { sq.ft.) }\end{array}$ & $\begin{array}{c}\text { Exergy Cost } \\
(\$ / \text { sq.ft.) }\end{array}$ \\
\hline HE-2 & $\begin{array}{r}\text { Recuperator } \\
\text { Liquid } \\
\text { Preheater }\end{array}$ & Bare & 100.3 & 5.22 & $4.75-7.71$ \\
\hline HE-4 & $\begin{array}{c}\text { Recuperator } \\
\text { Boiler } \\
\text { Condenser }\end{array}$ & Bare & 132.1 & 6.05 & $6.29-8.39$ \\
\hline HE-5 & $\begin{array}{c}\text { Brine/Aqua- } \\
\text { ammonia }\end{array}$ & Lo-fin & 77 & 2.68 & \\
\hline HE-6 & $\begin{array}{c}\text { Brine/Aqua- } \\
\text { ammonia }\end{array}$ & Lo-fin & 79.4 & 3.69 & - \\
\hline HE-9 & Brine/Steam & Lo-fin & 107.3 & 2.75 & - \\
\hline
\end{tabular}


Table 8-3

KCS11: Specific Power Output and Plant Cost

\begin{tabular}{|c|c|c|c|}
\hline Geothermal Site & NH3 Wt \% & $\begin{array}{c}\text { Specific Output } \\
(\mathrm{kW}-\mathrm{hr} / 1000 \mathrm{lb})\end{array}$ & $\begin{array}{c}\text { Specific Capital Cost } \\
(\$ / \mathrm{kW})\end{array}$ \\
\hline Thermo Hot Springs & 93.5 & 2.87 & 3,637 \\
\hline Raft River & 85.0 & 5.0 & 2,639 \\
\hline Vale, Oregon & 85.0 & 5.92 & 2,304 \\
\hline Surprise Valley & 80.86 & 9.19 & 1,885 \\
\hline
\end{tabular}


Table 8-4

Kalina Cycle System 11- Major Equipment Costs

\begin{tabular}{|c|c|c|c|c|}
\hline & $\begin{array}{l}\text { Thermal Hot } \\
\text { Springs }\end{array}$ & Raft River & Vale, Oregon & $\begin{array}{l}\text { Surprise } \\
\text { Valley }\end{array}$ \\
\hline & Kalina Cycle 11 & Kalina Cycle 11 & Kalina Cycle 11 & Kalina Cycle 1 \\
\hline $\begin{array}{l}\text { Plant Cost } \\
\text { Multiplier }\end{array}$ & 3.10 & 2.96 & 2.83 & \\
\hline Accumulators & \$. 219,096 & 190,583 & $\overline{194,130}$ & $\$ 153,725$ \\
\hline Heat Exchangers & 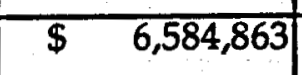 & $\$ \quad 8,819,258$ & $\$ \quad 5,448,153$ & $5,260,828$ \\
\hline $\begin{array}{l}\text { Air Cooler } \\
\text { Condenser }\end{array}$ & $\$ 15,435,074$ & $\$ 9,551,102$ & $\$ 9,817,388$ & $\overline{7,423,401}$ \\
\hline $\begin{array}{l}\text { Turbine Generator } \\
\text { Set }\end{array}$ & $\$ 11,115,853$ & $\$ 10,863,448$ & $\$ 10,813,576$ & $\begin{array}{ll}\$ 10,711,419 \\
\end{array}$ \\
\hline $\begin{array}{l}\text { Aqua-Ammonia } \\
\text { Pumps }\end{array}$ & 269,004 & 222,102 & 223,555 & 217,581 \\
\hline Injection Pumps & 184,102 & 127,866 & $\overline{111,715}$ & 85,821 \\
\hline Well Pumps & $\$ \quad 3,841,201$ & $\begin{array}{ll}\mathbf{2}, 122,686 \\
\end{array}$ & $\begin{array}{l}1,788,924 \\
\end{array}$ & $1,214,299$ \\
\hline Power Block Cost & $\$ 116,712,497$ & $\$ 94,415,253$ & $\$ 80,376,078$ & $\$ \quad 70,187,805$ \\
\hline Production Wells & $\$ 45,000,000$ & $\$ 26,250,000$ & $\$ 22,941,176$ & $\$ 17,000,000$ \\
\hline Injection Wells & $\$ 18,000,000$ & $\$ 10,500,000$ & $\$ 10,500,000$ & $6,000,000$ \\
\hline Gathering System & $2,138,213$ & $1,266,000$ & $1,204,000$ & 979,671 \\
\hline Total Cost & $\$ 181,850,710$ & $\$ 132,431,253$ & $\$ 115,021,255$ & $\$ 94,167,476$ \\
\hline
\end{tabular}


C

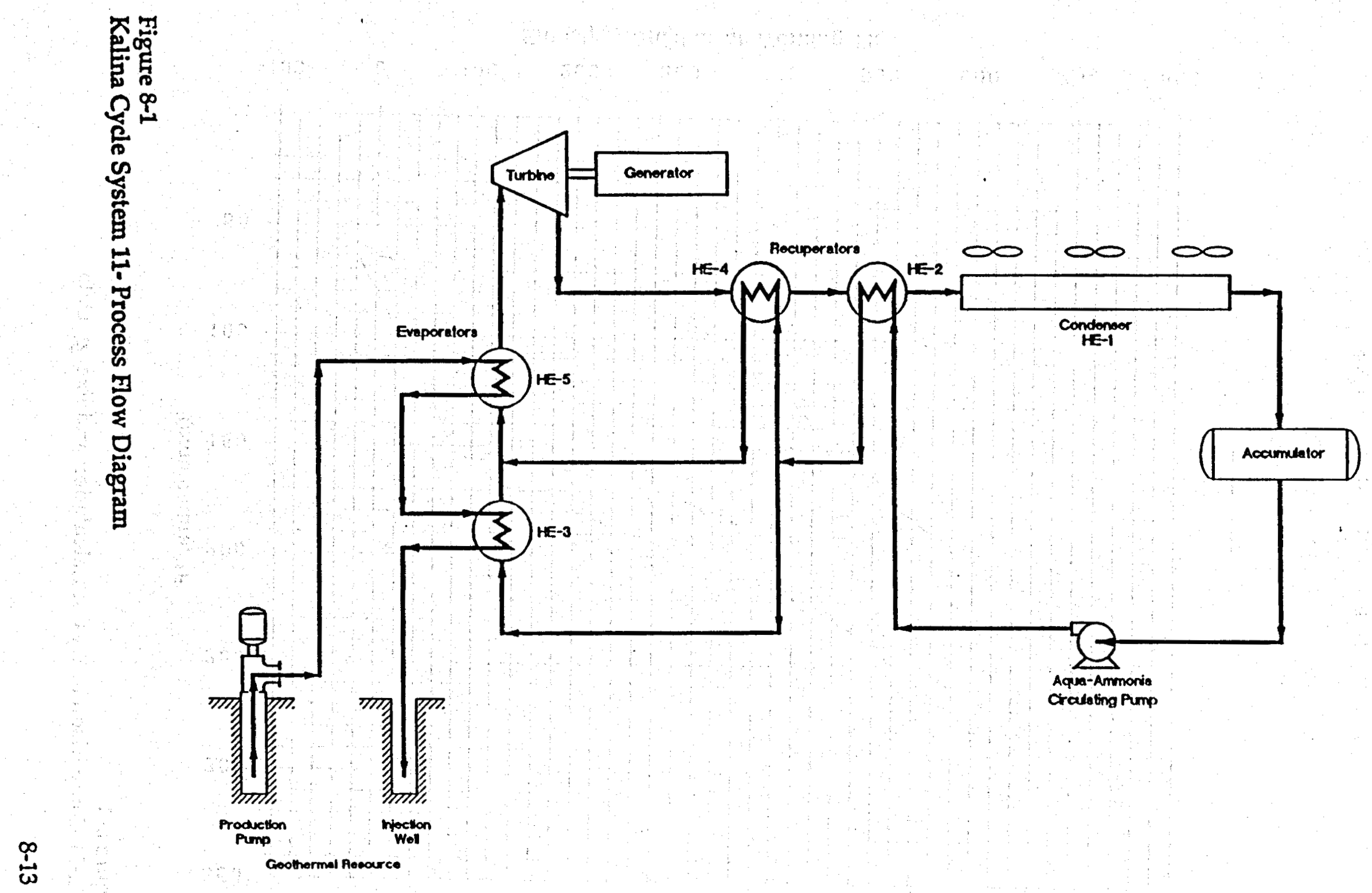



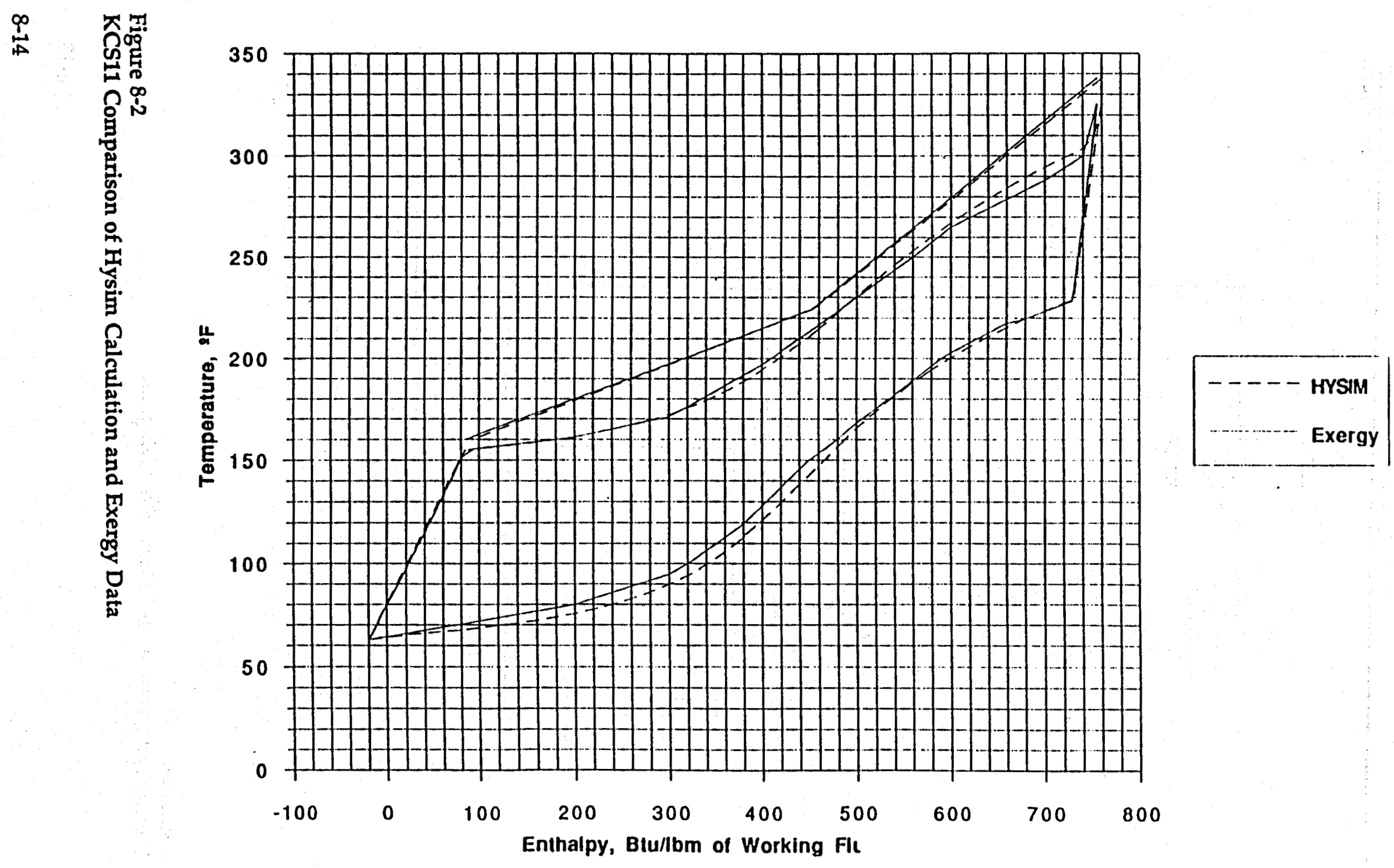

C

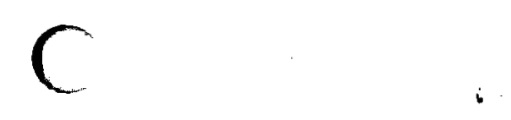


Plant Cost v/s NH3 Concentration, KCS11

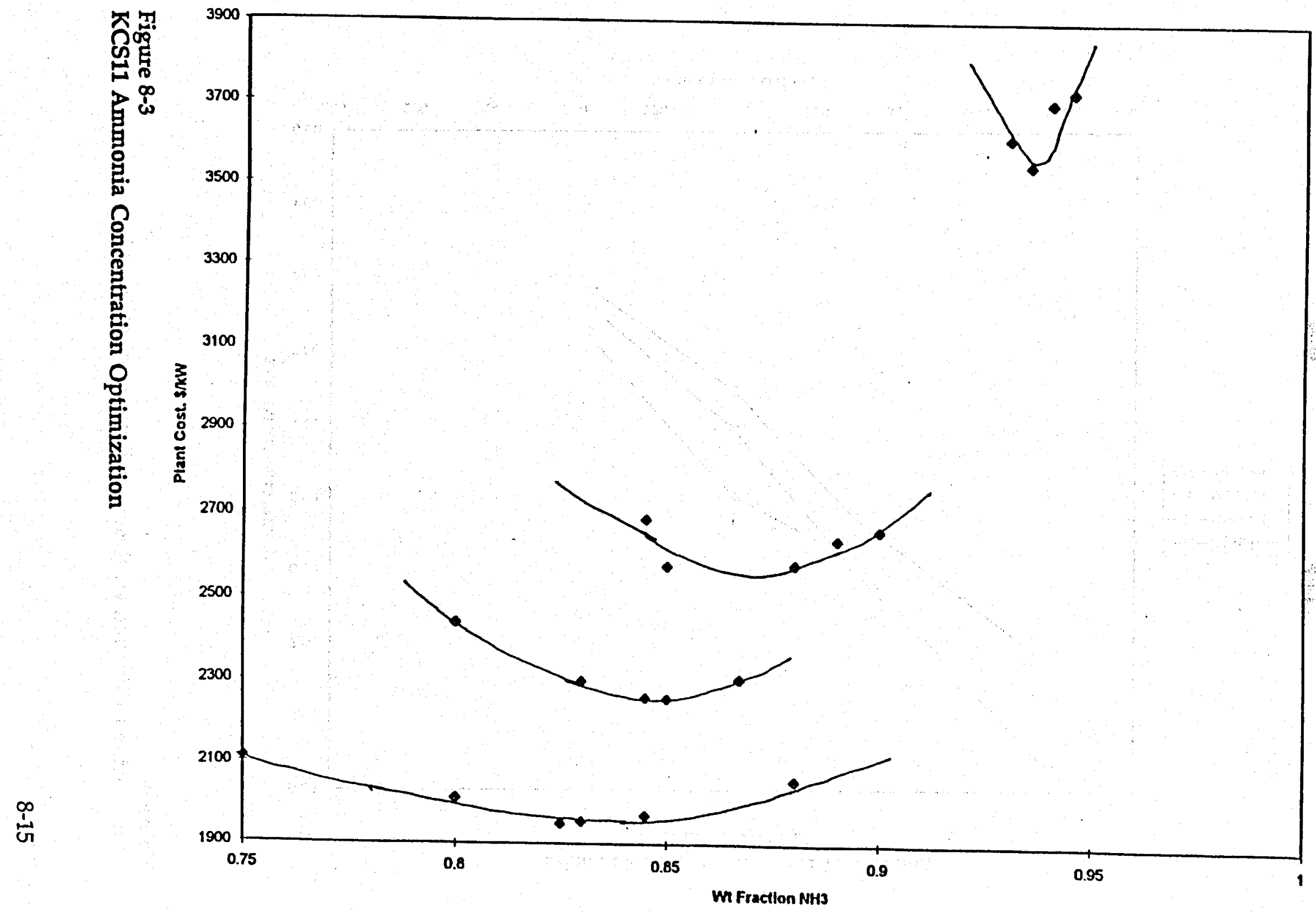




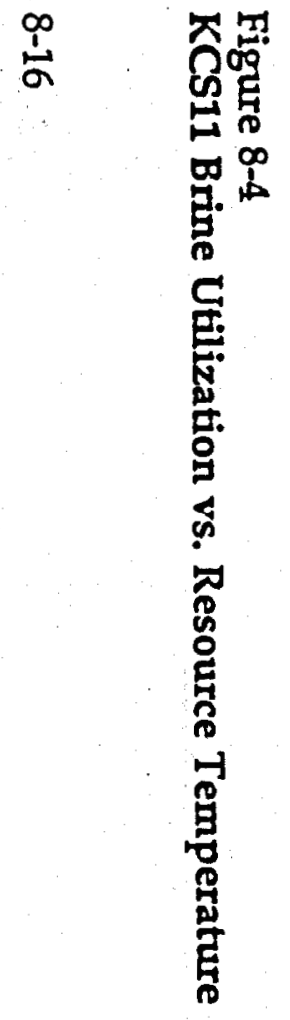

Brine Utilization v/s Resource Temperature Kalina Cycle 11
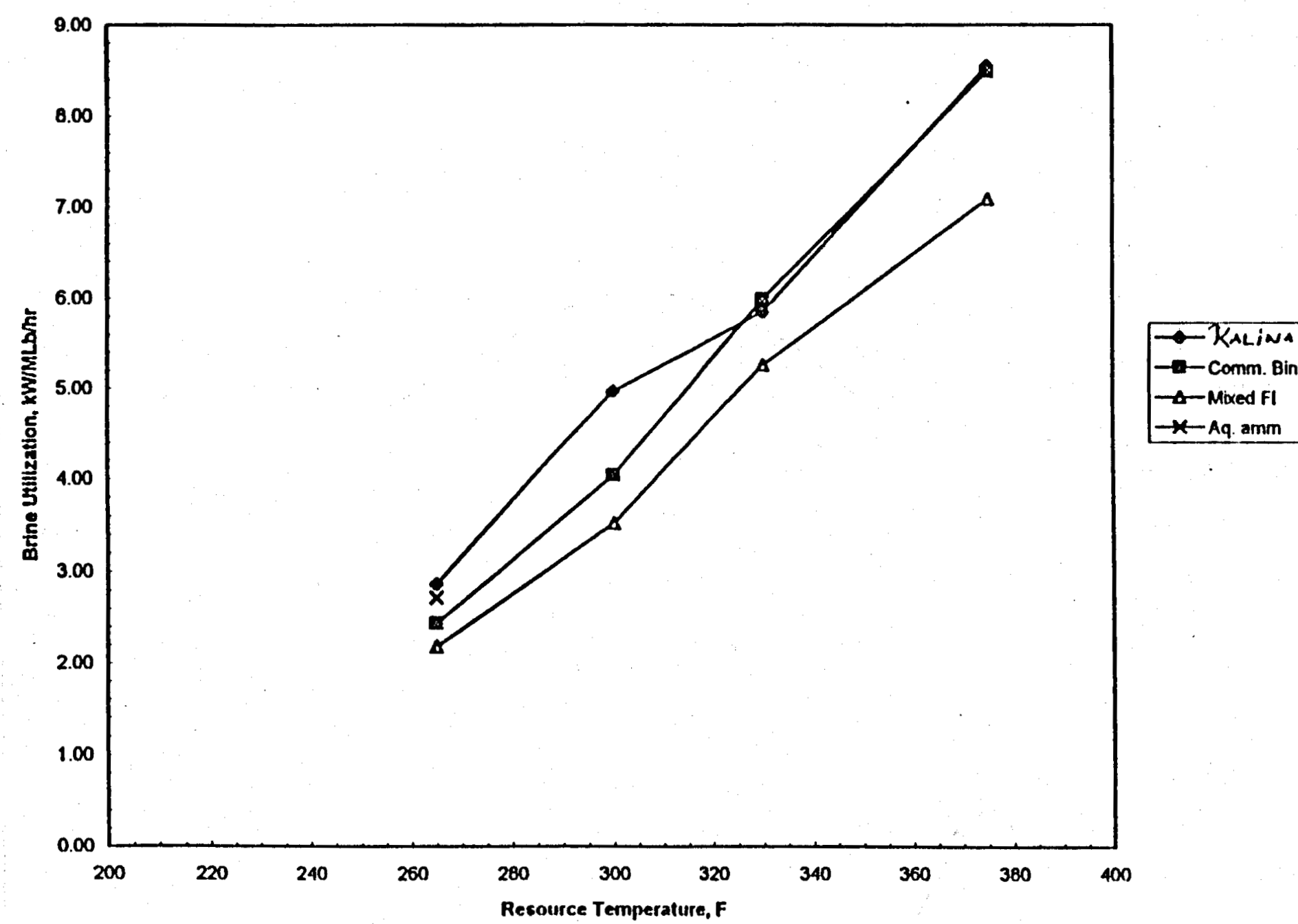
c

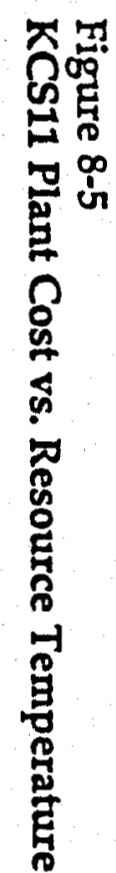

Plain Cost v/s Resource Temperature

Kalina Cycle 11

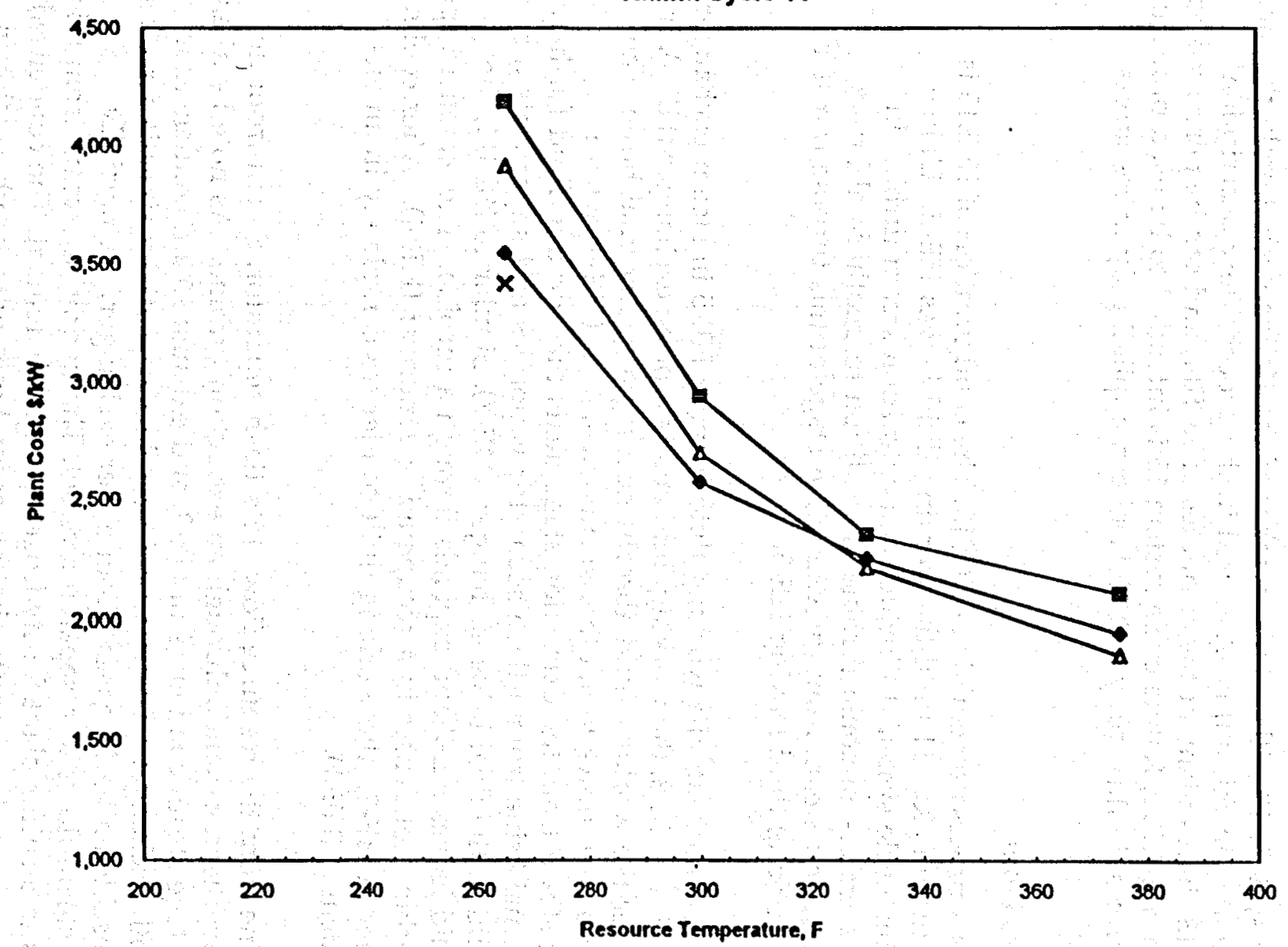




\section{Kalina Cycle System 13}

\section{Introduction}

Kalina cycle system 13 is the other member of the Kalina cycle family that has been investigated in this study. As noted in the process flow description below, KCS13 shares many of the attributes of KCS11, and can be perceived as an extension of KCS11. Kalina cycle system 13 is intended to be used primarily for hot resources. In this study KCS13 has been applied only to resources above $400^{\circ} \mathrm{F}$.

\section{Cycle Process Flow}

Figure $8-6$ is a process schematic of KCS13. The configuration of KCS13 is identical to that of KCS11 until the working fluid leaves HE-5. Unlike KCS11, Kalina cycle system 13 includes an extraction steam turbine in addition to a water-ammonia turbine. In addition to geothermal brine, exhaust steam and steam from the extraction stage of this turbine transfer heat to the working fluid leaving HE-5.

The exhaust steam heats the working fluid leaving HE-5 in steam exchanger, $\mathrm{HE}-8$. On exiting HE-8, the working fluid enters a brine exchanger (HE-6). In this exchanger the working fluid absorbs heat from geothermal brine. The working fluid then flows to another steam exchanger (HE-9) where condensing steam from the extraction stage heats the working fluid further. The geothermal brine from a flash separator vaporizes and superheats the working fluid in the final brine exchanger (HE-7). Similar to KCS11, the working fluid leaves HE-7 and expands through a turbine. The exhaust vapor from the turbine condenses in a recuperative vaporizer (HE-4). After cooling down further in HE-2, the working fluid condenses completely in an aircooled condenser (HE-1).

The hot brine from the resource flows to a flash separator. Steam from the separator overhead expands through an extraction turbine. As noted earlier, extraction stage steam condenses in HE-9, and exhaust steam condenses in HE-8. In both exchangers the steam only condenses partially since it contains non-condensable and acid gases. From either exchanger, the partially condensed steam flows to a separator vessel. The overhead stream from this vessel goes to a sulfur plant for hydrogen sulfide abatement. The condensed liquid stream from the separator bottom recombines with geothermal brine. 


\section{Performance Analysis}

\section{Description}

Kalina cycle system 13 is modeled using an approach similar to that used for modeling KCS11. A HYSIM model using PRSV thermodynamics forms the basis for simulating KCS13 cases. The control temperature specifications are listed under assumption 1 below. These specifications are the same as those provided by Exergy, Inc.

The inclusion of the extraction steam turbine in $\mathrm{KCS} 13$ has certain model implications that do not apply to KCS11. These are noted below:

- The extraction stage pressure is fixed by setting the final evaporator brine outlet temperature equal to the extraction steam temperature.

- The steam turbine exhaust pressure is fixed by setting the third brine evaporator outlet temperature equal to the exhaust steam temperature.

Similar to KCS11, a number of cases have been simulated at various ammonia concentrations for KCS13 for each resource. Figure 8- shows the optimization plots for KCS13 applied to Desert Peak, Dixie Valley, Glass Mountain and Salton Sea.

\section{Assumptions}

The general data used to design geothermal power plants using $\mathrm{KCS} 13$ is listed in Tables 4-1 to 4-5. All KCS11 modeling assumptions except assumption (2) also apply to KCS13. Assumption (2) relates to the overall efficiency of the turbine-generator system. The overall efficiency of the aquaammonia turbines for KCS13 was taken to be 0.795 . This value of the overall efficiency is derived from data provided by Fuji Electric Company.

The following specific assumptions were used to design power plants using KCS13:

(1) Simulation of $\mathrm{KCS} 13$ was performed using the following temperature specifications:

- HE-2 hot end approach is $10^{\circ} \mathrm{F}$.

- HE-5 cold end approach is $10^{\circ} \mathrm{F}$.

- Aqua-ammonia outlet temperature of HE-3 and HE-4 are equal.

- HE-7 hot end approach is $10^{\circ} \mathrm{F}$.

- HE-8 hot end approach is $10^{\circ} \mathrm{F}$. 
- HE-6 cold end approach is $10^{\circ} \mathrm{F}$.

- HE-9 steam inlet temperature equals HE-6 brine inlet temperature.

(2) In simulating KCS13, non-condensable gases, namely, carbon dioxide and hydrogen sulfide, were included in the geothermal brine composition since the geothermal brine is flashed in KCS13. This implies that steam condensation in HE-8 and HE-9 is not isothermal. To keep steam condensation nearly isothermal, HE-8 and HE-9 are operated such that steam is only partially condensed in the two exchangers. Thus, streams 44 and 48 have vapor fractions slightly greater than zero. These two streams are sent to flash separators to separate vapor and liquid. The vapor stream from the flash separator is sent to a sulfur plant for sulfur recovery from hydrogen sulfide, while the liquid stream is pumped back into the geothermal brine stream used to heat the working fluid.

The geothermal brine at Coso Hot Springs contains 2 wt \% noncondensable gases. This implies that Kalina cycle 13 would not be practical at Coso Hot Springs since a large quantity of steam would have to be vented in order to condense steam in HE-8 and HE-9 under near isothermal conditions.

\section{Cost Analysis}

\section{Description}

The methodology used for calculating plant costs for KCS13 cases is essentially identical to that used for calculating plant costs for KCS11 cases. The following additional cost details apply to KCS13:

- Kalina cycle system 13 has four more exchangers than KCS11. All additional $\mathrm{KCS} 13$ exchangers are in the aqua-ammonia vaporization loop.

- The cost of a sulfur plant and an extraction steam turbine is included in the plant cost of KCS13.

\section{Results}

Figure 8-7 shows the results of ammonia concentration optimization for KCS13. The figure is a plot of specific capital cost as a function of ammonia concentration for the four sites that were used to evaluate KCS13: Desert Peak, Dixie Valley, Glass Mountain, and Salton Sea. The optimization curves for the four sites show that specific capital cost for KCS13 is relatively insensitive to changes in ammonia concentration. This result agrees with the KCS11 
optimization results where it was observed that the specific capital cost curves were flatter at higher resource temperature (see Figure 8-3). The nature of the specific capital cost versus ammonia concentrations curves indicates that for the purposes of this study any errors in selection of optimum ammonia concentration for KCS13 will affect the cycle evaluation only marginally. The results for KCS13 are summarized in Table 8-5 and Table 8-6. Figures 8-8 and 8-9 are plots of specific output and specific capital cost, respectively, for KCS13 and the commercial dual flash cycle. The following broad conclusions can be inferred from these figures:

- Specific capital costs for the optimum dual flash cycle are significantly lower than those for KCS13. The reasons for this consistently superior performance of the dual flash cycles are two-fold:

- Kalina cycle 13 uses air coolers for condensation whereas the dual flash cycles use water cooling for condensation. The use of aircoolers results in higher capital costs for Kalina 13 as well as higher parasitic loads compared to dual flash cycles.

- The use of two turbine-generator sets, necessitated by cycle configuration, for KCS13 compared to only one for the dual flash cycles has an appreciable impact on raising costs for $\mathrm{KCS} 13$ due to economies of scale. Furthermore, costs for the extraction steam turbine per unit of power are significantly higher than similar costs for steam turbines used in flash plants.

- Due to heat recuperation from geothermal brine, KCS13 yields higher a specific output compared to the commercial dual flash cycle for all four sites as Figure 8-8 shows. 
Kalina Cycles

Table 8-5

KCS13: Specific Power Output and Plant Cost

\begin{tabular}{|l|l|l|l|}
\hline Geothermal Site & NH3 Wt \%, & $\begin{array}{l}\text { Specific Output } \\
(\mathrm{kW}-\mathrm{hr} / 1000 \mathrm{lb})\end{array}$ & $\begin{array}{l}\text { Specific Capital } \\
\text { Cost }(\$ / \mathrm{kW})\end{array}$ \\
\hline Desert Peak & 88.0 & 12.7 & 1,812 \\
\hline Dixie Valley & 92.0 & 14.85 & 1,693 \\
\hline Glass Mountain & 86.7 & 18.45 & 2,022 \\
\hline Salton Sea & 80.0 & 19.92 & 1,522 \\
\hline
\end{tabular}


Table 8-6

Kalina Cycle System 13 - Major Equipment Cost

\begin{tabular}{|c|c|c|c|c|}
\hline & Desert Peak & Dixie Valley & Glass Mountain & Salton Sea \\
\hline & Kalina Cycle 13 & Kalina Cycle 13 & Kalina Cycle 13 & Kalina Cycle 13 \\
\hline $\begin{array}{l}\text { Plant Cost } \\
\text { Multiplier }\end{array}$ & 2.53 & 2.53 & 2.53 & $\overline{2.5}$ \\
\hline Accumulators & 127,233 & $\begin{array}{ll}\mathbf{1 3 4 , 5 5 4} \\
\end{array}$ & $\$ 142,760$ & $\$ \$ 141,75$ \\
\hline $\begin{array}{l}\text { Separators, } \\
\text { Silencers, Misc }\end{array}$ & $\$ \quad 324,796$ & $\$ \quad 322,535$ & $\$ 322,278$ & $\$ 326,919$ \\
\hline $\begin{array}{l}\text { Heat } \\
\text { Exchangers } \\
\end{array}$ & $\begin{array}{l} \\
\end{array}$ & $\$ \quad 2,325,131$ & $\$ 2,460,062$ & $\$ 2,762,92$ \\
\hline $\begin{array}{l}\text { Air Cooler } \\
\text { Condenser }\end{array}$ & 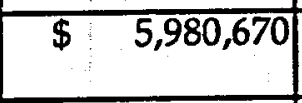 & $\begin{array}{ll}\$ & 7,259,872 \\
\end{array}$ & $\$ 6,502,785$ & $\$ 5,267,52$ \\
\hline $\begin{array}{l}\text { Turbine Generator } \\
\text { Set }\end{array}$ & $\$ 17,779,451$ & \begin{tabular}{|l|}
$\$ 18,845,066$ \\
\end{tabular} & $\$ 18,472,146$ & $\$ 17,254,042$ \\
\hline Sulfur Plant & $\$ \quad 351 ; 673$ & $\$ \quad 355,969$ & $1,128,806$ & $\$ 843,305$ \\
\hline $\begin{array}{l}\text { Aqua-Ammonia } \\
\text { Pumps }\end{array}$ & \$ $\quad 227,898$ & $\$ \quad 168,901$ & $\$ 170,226$ & $\$ 266,570$ \\
\hline Injection Pumps & 78,802 & 70,208 & $\$ 60,711$ & $\$ 58,949$ \\
\hline Power Block Cost & \$ $68,848,009$ & \$ $74,590,056$ & $\$ 74,027,227$ & $\$ 68,112,633$ \\
\hline Production Wells & $\$ 14,457,831$ & $\$ \quad 6,428,571$ & $\$ 18,000,000$ & $\$ 5,000,000$ \\
\hline Injection Wells & $\$ \quad 6,000,000$ & $\$ \quad 3,000,000$ & $\$ 7,500,000$ & $\$ 2,500,000$ \\
\hline Gathering System : & $\$ 1,322,466$ & 625,234 & $\$ 1,561,653$ & $\$ 463,665$ \\
\hline Total Cost & $\$ 90,628,307$ & $\$ 84,643,862$ & $\$ 101,088,880$ & $\$ 76,076,298$ \\
\hline
\end{tabular}




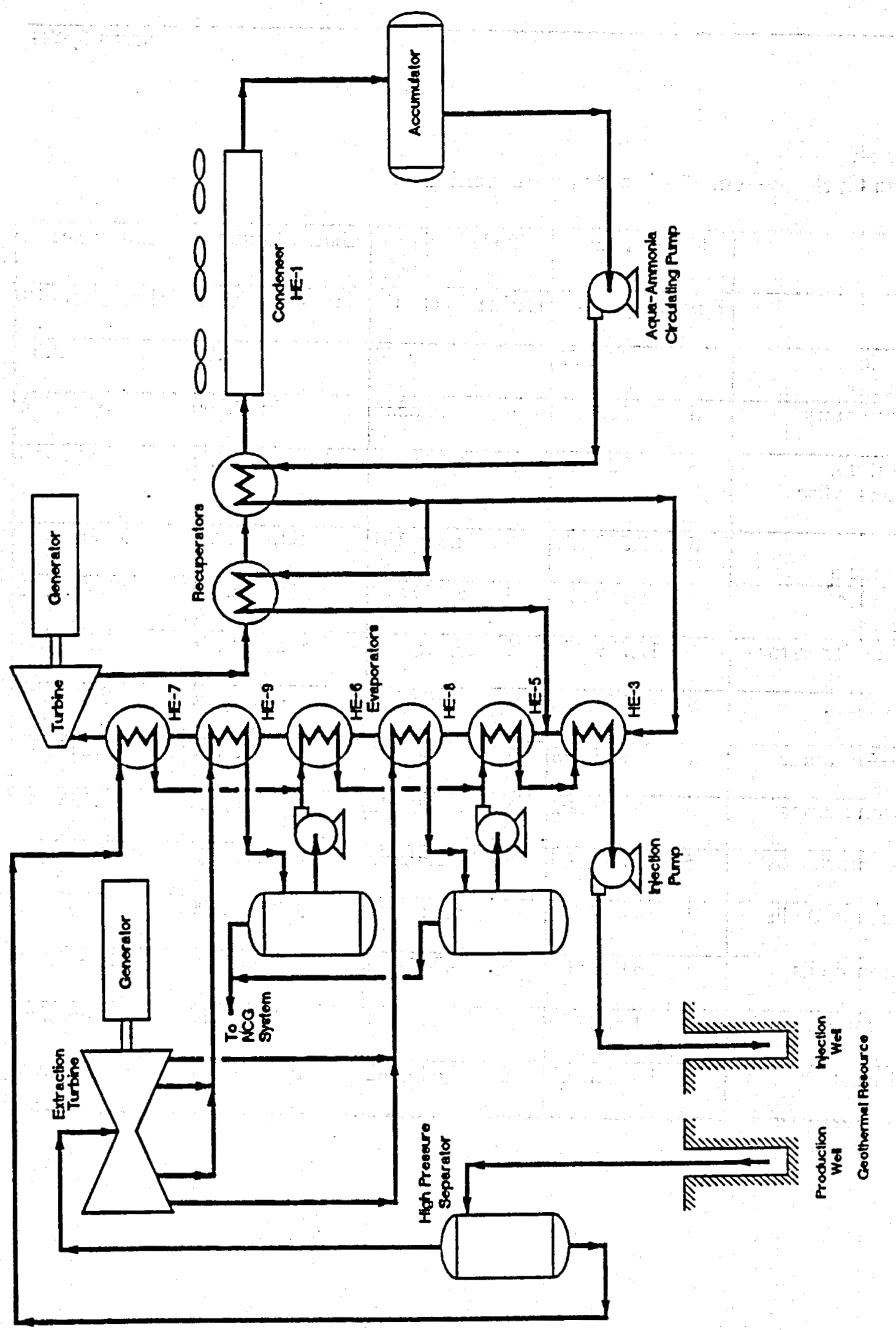

Figure 8-6

Kalina Cycle System 13- Process Flow Diagram 
$\cup$

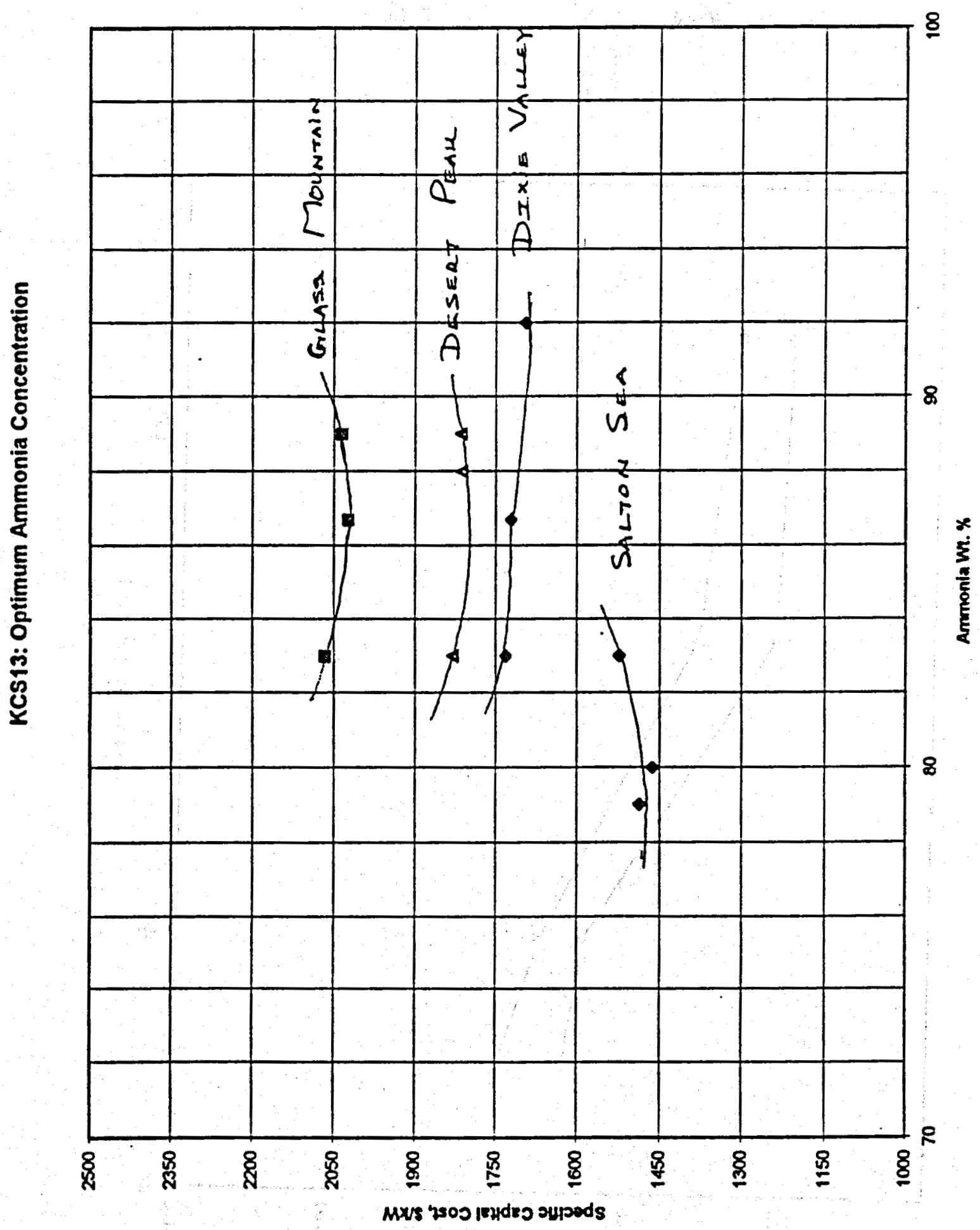

Figure 8-7

KCS13 Optimum Ammonia Concentration 

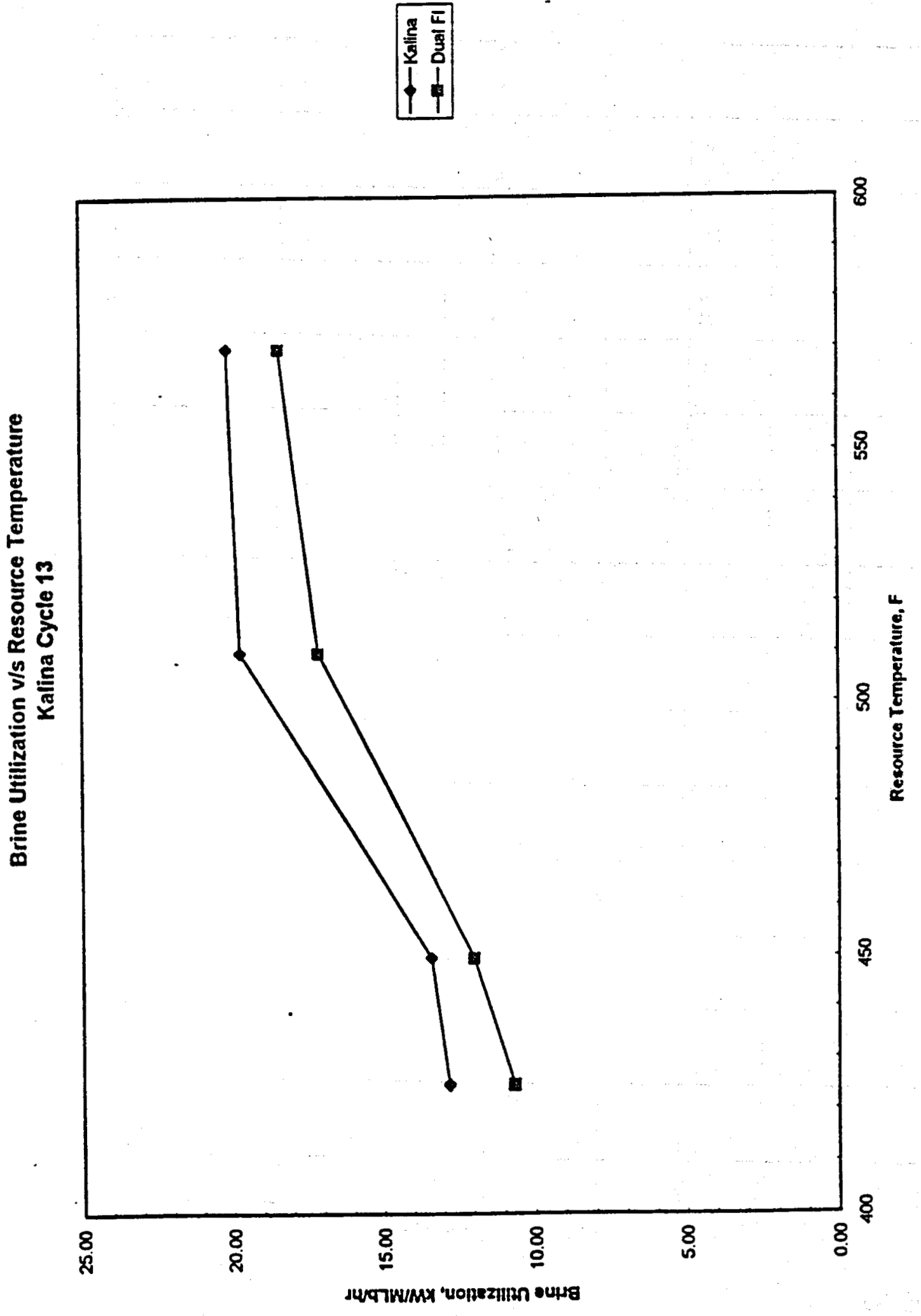

Figure 8-8

KCS13 Brine Utilization vs. Resource Temperature 


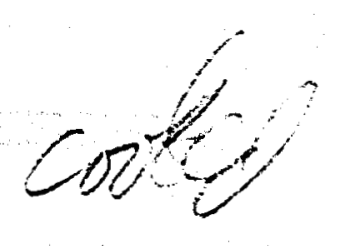

\section{HYBRID CYCLES}

\section{Dual Flash/Binary Bottoming Cycle}

\section{Introduction}

The binary bottoming cycle is a combination of dual flash and binary technology. Dual flash technology is generally more cost effective for hot resources, while binary technology is more cost effective for cold resources: the hybrid plant attempts to use each type of technology in the temperature range where it is most cost effective.

\section{Cycle Process Flow}

Figures 9-1 and 9-2 show two simplified process flow diagrams for binary bottoming cycles. The first is a dual flash/binary bottoming hybrid plant. The second is a single flash, binary bottoming hybrid plant. The dual flash portion of the hybrid plant is identical to the dual flash cycle, discussed in section 5, except that instead of injecting it into the gound, the bottoms from the low pressure separator is used to heat the hydrocarbon working fluid in the binary cycle. The binary cycle is identical to the air cooled binary cycle discussed in. section 5 .

The single flash/binary hybrid process is the same as the dual flash/binary hybrid except that the flash plant does not have a low pressure separator, and has a single entry turbine. In the single flash cycle the bottoms from the high pressure separator is used to heat the binary cycle.

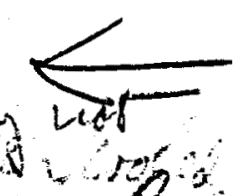

\section{Performance Analysls}

\section{Description}

Flash/binary hybrid cycles were analyzed using the methodologies used to analyze dual flash and binary cycles. The temperature and enthalpy of the separator bottoms stream from the dual flash model was input to the binary plant model. Binary cycle net power, hydrocarbon flow rate and pump work were input into a modified dual flash model which was used to calculate the overall hybrid plant net power. 
The flash pressures determine the amount of power that will be produced by each part of the hybrid plant. For each site, a case was run at the dual flash optimum flash pressures. In addition, several cases were run raising the low pressure flash pressure incrementally until there was only a single flash. As the low pressure flash pressure increases, the amount of low pressure steam to the steam turbine decreases, and more and hotter brine is sent to the binary plant.

\section{Assumptions}

Assumptions used in the analysis of binary and dual flash cycles are applicable to the flash/binary hybrid cycles.

\section{Cost Analysis}

\section{Assumptions}

Economic analysis of the binary bottoming hybrid plants was performed using the same methods and assumptions as those used to calculate the cost of flash plants and binary plants individually. Off-site costs such as the well costs, and the gathering and injection system costs were included in the flash portion of the plant cost.

\section{Results}

\section{Performance}

The results of the thermodynamic analysis are shown on Table 9-1. Each row represents one case. The second column shows the low pressure flash pressure as it is raised incrementally from the dual flash optimum up to a single flash. The third column shows the brine utilization for each case. The brine utilization in all cases is better than that for dual flash alone. Furthermore, it is thermodynamically favorable to raise the low pressure flash pressure above the dual flash optimum to divert more and hotter brine to the binary part of the plant. However, as more and hotter brine is diverted to the binary part of the plant, less low pressure steam is available for the flash part of the plant, and there is a point of diminishing return where total net power production levels off. In Table 9-1, the optimum brine utilization is in bold face.

For the Glass Mountain site, the optimum plant has a low pressure flash at 100 psia. For the Desert Peak site, the optimum is at about 50 psia. For the colder resources of Surprise Valley, Vale, and Raft River, it is best to eliminate the second flash altogether and use a single flash plant.

\section{Economics}

The results of the economic analysis are presented along side the results of the thermodynamic analysis on Table 9-1. The fourth column gives the 
specific capital cost of the hybrid plant. The fifth and sixth columns give the specific capital cost of the flash and binary parts of the plant respectively.

The first cases for each site have the same flash pressures as the economic optimum dual flash cases. In each of these cases, the specific cost of the dual flash part of the plant is slightly more than the conventional dual flash specific capital cost (refer to Table 5-7). This is due to the fact that these flash portions of the hybrid plants are smaller, and the economy of scale makes the full size dual flash plant more economical.

Looking at the first Glass Mountain hybrid plant as an example, it can be seen that the binary part of the plant is operating with a $242^{\circ} \mathrm{F}$ resource. The cost of binary power production for such a cold resource is very high as seen in the air-cooled binary plant analysis in Section 5 . The incremental cost to add a 4 MW binary plant down stream of the flash plant is therefore high. As the flash pressure is raised, the cost of the flash part of the plant rises because of the diminishing scale as well as the fact that the flash pressures diverge from the optimum. The cost of the binary plant decreases because it receives a hotter resource. An economic optimum is found in each case. For the hotter resources, Glass Mountain and Desert Peak, adding a binary bottoming cycle is not cost effective compared to dual flash technology alone.

For the coldest resource, Raft River, the cost of the hybrid plant is lower than the dual flash economic optimum plant. This is due to the fact that nearly half of the power is made by the binary part of the plant, and binary technology is preferred at low temperatures. The cost of the hybrid plant is not however lower than the air-cooled binary plant at Raft River.

The Surprise Valley hybrid plant has nearly the same capital cost per kilowatt than both the air cooled binary cycle at that site. 


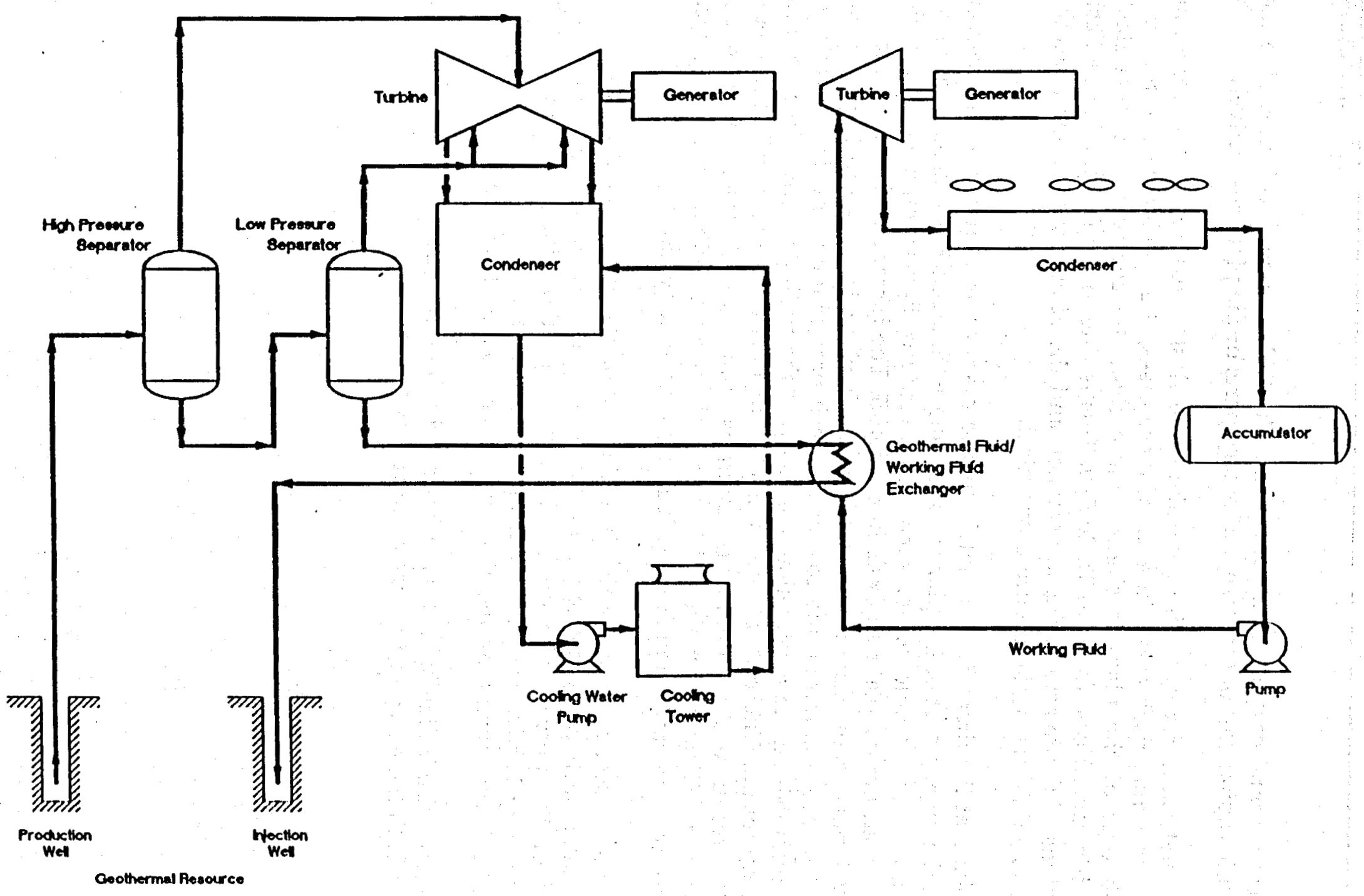

C 


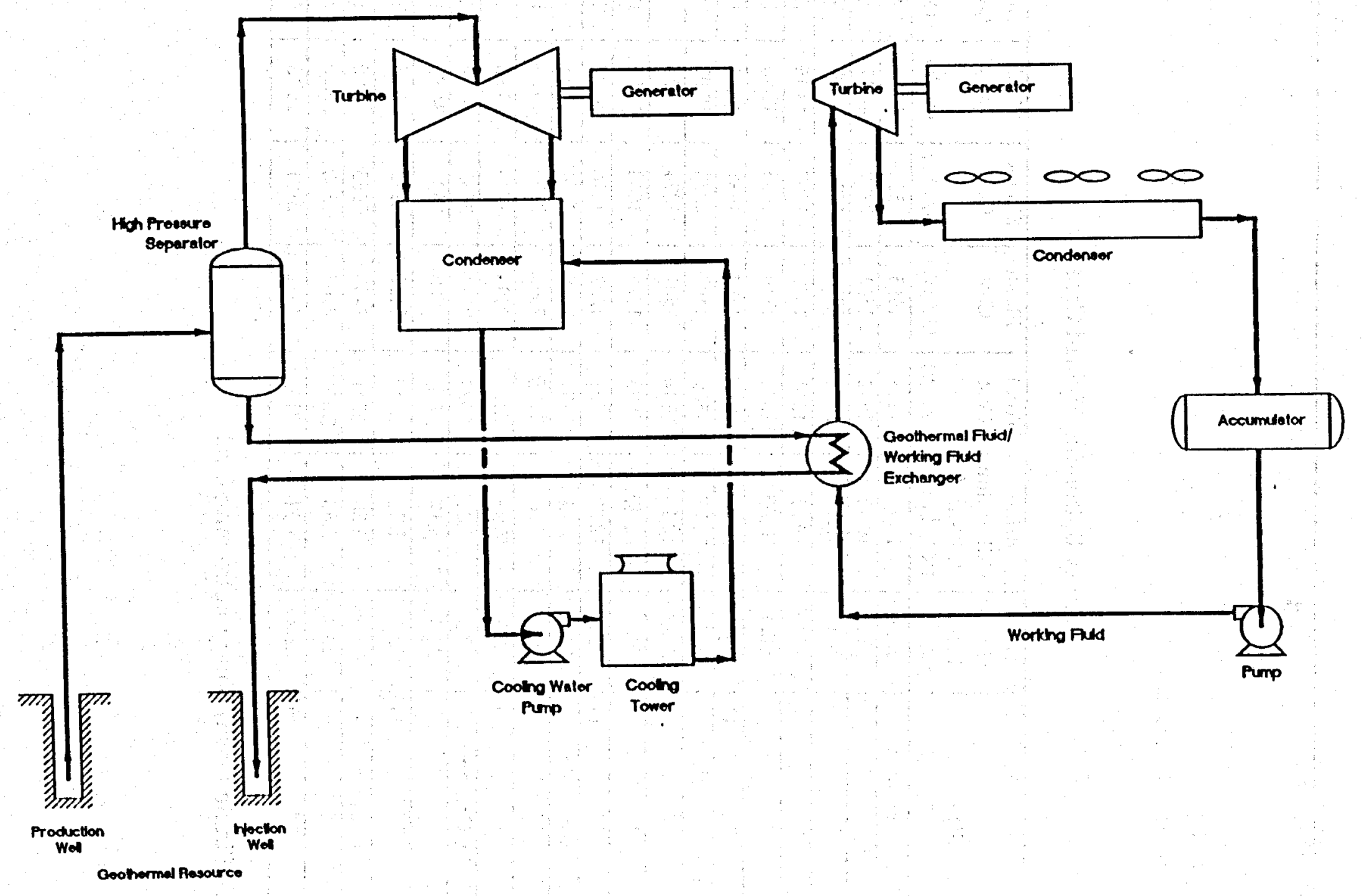


Table 9-1

Summary of Cases

Binary Bottoming Hybrid Cases

\begin{tabular}{|c|c|c|c|c|c|c|c|}
\hline Site & $\begin{array}{l}\text { Low } \\
\text { Flash } \\
\text { Press } \\
\text { (Psia) }\end{array}$ & $\begin{array}{c}\text { Brine } \\
\text { Utilization } \\
\text { (kW-hr / } \\
1 \mathrm{~K} \mathrm{lb} \text { brine) }\end{array}$ & $\begin{array}{c}\text { Total } \\
\text { Cost } \\
(\$ / \mathrm{kW})\end{array}$ & $\begin{array}{c}\text { Flash } \\
\text { Cost } \\
(\$ / \mathrm{kW})\end{array}$ & $\begin{array}{l}\text { Binary } \\
\text { Cost } \\
(\$ / \mathrm{kW})\end{array}$ & $\begin{array}{l}\text { Flash } \\
\text { Output } \\
\text { (MW) }\end{array}$ & $\begin{array}{l}\text { Binary } \\
\text { Output } \\
\text { (MW) }\end{array}$ \\
\hline Glass Mountain & 26.0 & 18.78 & 1648 & 1565 & 2568 & 46.54 & 4.17 \\
\hline$" n$ & $\overline{35.0}$ & 19.42 & 1642 & 1562 & 2229 & 46.17 & 6.27 \\
\hline$" 1$ & 50.0 & $\overline{19.44}$ & 1635 & 1586 & 1931 & 45.07 & 7.40 \\
\hline$" 1$ & 70.0 & 19.71 & 1644 & 1632 & 1697 & 43.15 & 10.05 \\
\hline$" n$ & 100.0 & 20.03 & 1690 & 1719 & 1608 & 40.05 & 14.03 \\
\hline (1) & 151.0 & 19.68 & 1786 & 1857 & 1651 & 34.83 & 18.32 \\
\hline Desert Peak & 21.5 & 11.77 & 1565 & 1497 & 2233 & 48.02 & 4.93 \\
\hline $7 "$ & 30.0 & 12.15 & $\overline{1544}$ & 1501 & 1824 & 47.35 & 7.37 \\
\hline $7 "$ & 50.0 & $\overline{12.47}$ & 1595 & 1576 & 1660 & 43.86 & 12.26 \\
\hline (1) & 90.0 & 12.32 & 1721 & 1782 & 1616 & 34.97 & 20.46 \\
\hline Surprise Valley & $\overline{12.5}$ & 7.15 & 2191 & 2055 & 3074 & 42.11 & 6.48 \\
\hline "1" & 25.0 & 7.86 & 2129 & 2063 & 2335 & 40.59 & 12.85 \\
\hline (1) & $\overline{51.5}$ & 7.93 & 2179 & 2493 & 1789 & 29.86 & 24.02 \\
\hline Vale, Oregon & 12.5 & 4.83 & 2674 & 2624 & 3037 & 36.94 & 9.78 \\
\hline 7 & 20.0 & 5.17 & 2669 & 2708 & 2582 & 34.85 & 15.65 \\
\hline (1) & $\overline{35.4}$ & 5.21 & 2759 & 3432 & 2123 & 24.53 & 26.01 \\
\hline Raft River & 12.5 & 3.80 & 3341 & 3498 & 2963 & 33.90 & 14.05 \\
\hline 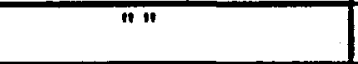 & 20.0 & 3.88 & 3068 & 3665 & 2360 & 26.50 & 22.37 \\
\hline (1) & 28.2 & 3.91 & 3167 & 4862 & 2181 & 18.13 & 31.17 \\
\hline
\end{tabular}

(1) Single Flash/Binary Bottoming Cycle 


\section{Dual Flash/Back Pressure Turbine Binary}

\section{Introduction}

While the binary bottoming cycle is essentially a conventional dual flash plant with a conventional binary plant added down stream, the back pressure turbine cycle combines flash and binary technology with major modifications, as discussed below, to each of the processes.

\section{Cycle Process Flow}

Figure 9-3 shows a simplified process flow diagram for the this cycle. The major modification to the dual flash part of the plant is the elimination of the cooling water system. Since the absence of any emissions is a primary advantage of this cycle, it was assumed that noncondensable gases can be injected. For all other flash cycles, noncondensable gases were emitted to the atmosphere. This makes the back pressure turbine cycle a closed cycle. A steam - hydrocarbon heat exchanger functions as the steam condenser for the dual flash process. The hydrocarbon side of this exchanger is used to heat the working fluid in the binary cycle. A compressor is used to pressurize the noncondensable gases in the steam so that they can be injected into the reservoir.

The components of the flash part of the plant upstream of the steam turbine are the same as those in a conventional dual flash plant. Likewise, except for the steam-hydrocarbon heat exchanger, the binary part of the plant is the same as an air cooled binary cycle power plant.

\section{Performance Analysis}

\section{Assumptions}

In analyzing the dual flash/back pressure turbine binary cycles, the steam side pressure at the outlet of the condenser was fixed at one atmosphere, and a two pound pressure drop on the steam side of the condenser was assumed. Thus, the turbine back pressure was set at two pounds above atmospheric. For the resource temperatures of interest, this makes for roughly equal contributions to the total net power output from both parts of the hybrid plant when the cycles are optimized. Decreasing the back pressure leads to a greater contribution of the power output from the steam turbine. Along with this, however, comes the potential for air leakage into the process, and the requirement for a greater amount of power to compress the noncondensable gases for injection.

The binary turbine inlet temperature was fixed by setting the approach temperature on the condenser; $5^{\circ} \mathrm{F}$ was chosen as the minimum approach temperature. Finally, specifying the air cooler approach temperature fixed 
the hydrocarbon state points. A minimum $20^{\circ} \mathrm{F}$ approach on the air cooler was used. Since the back pressure of the steam turbine is nearly the same for all cases, varying only with the atmospheric pressure at the individual sites, the binary cycle state points are nearly the same for all the hybrid plant cases. The amount of steam condensed determines the condenser duty, the amount of working fluid circulation, and therefore the amount of power produced by the binary cycle.

\section{Cost Analysis}

\section{Assumptions}

The economic analysis methodologies used for flash and binary cycles were also used for analyzing dual flash/back pressure turbine binary hybrid power plants. The costs for the condenser, cooling water system, vacuum system and the sulfur plant were omitted from the dual flash cost model and the cost of a gas compressor was added. Off- site costs were included in the flash part of the plant. The only adjustment made to the binary plant cost model involved changing the overall heat transfer coefficient on the hydrocarbon heater: in the instant case it was calculated for each case since the driving force is condensing steam instead of hot liquid. However, heat exchanger costs were assumed to be $\$ 7.57$ per square foot of surface area, the same as those for the brine-to-isobutane heat exchanger in the binary cycle.

\section{Results}

\section{Performance}

The flash pressures in the flash part of the plant affect the power output of both parts of the hybrid plant. Figure 9-4 shows the power produced by each part of the plant and the total plant power as a function of low pressure flash pressure at Glass Mountain. The high pressure flash pressure is kept at a constant 151 psia. This is the wellhead pressure, so there is no freedom to raise it, and it is thermodynamically unfavorable to lower it. The plot shows that the optimum low pressure flash pressure is at $53 \mathrm{psia}$. This coincides with a maximum in the power output of the steam turbine. This optimum flash pressure is higher than the 26 psia optimum for the conventional dual flash case because the condenser temperature in the back pressure turbine cycle is higher. Increasing the flash pressure produces a smaller quantity of low pressure steam and thereby less power in the binary side. This levels off because there is a fixed amount of steam from the high pressure flash.

Optimizing the flash pressures is the primary task in optimizing the back pressure turbine cycle. At each site, once the best flash pressure is found, the brine utilization is better than for conventional dual flash technology alone. This is as expected because the plant is part binary which has an inherently better brine utilization. 


\section{Economics}

The back pressure turbine cycle has several parameters which must be optimized. These are parameters that normally have to be optimized in either dual flash or binary plants when they are investigated separately. A plot of specific plant cost vs. low pressure flash pressure for Glass Mountain (Figure 9-5) shows that the thermodynamic optimum flash pressure, 53 psia, is also the economic optimum. This result with regard to the flash pressures was true for all of the back pressure turbine cycles investigated and the same was found with the dual flash investigations.

For each case, an approach temperature on the condenser of $15^{\circ} \mathrm{F}$ is found to be the most cost effective. The amount of surface area, and therefore condenser cost, required to give a lower approach temperature is not justified by the amount of added power produced. For the air coolers, an approach temperature of $28^{\circ} \mathrm{F}$ is found to be the most cost effective. These results are consistent for all cases because the binary cycle heat source and rejection temperatures are very similar for all cases.

Table 9-2 gives the major equipment costs for the most economical plant at each site. It is clear from the table that as the resource temperature declines, the power production and therefore the plant cost shifts from the flash part of the plant to the binary part of the plant. In none of the cases is the capital cost less than either dual flash or binary alone. 

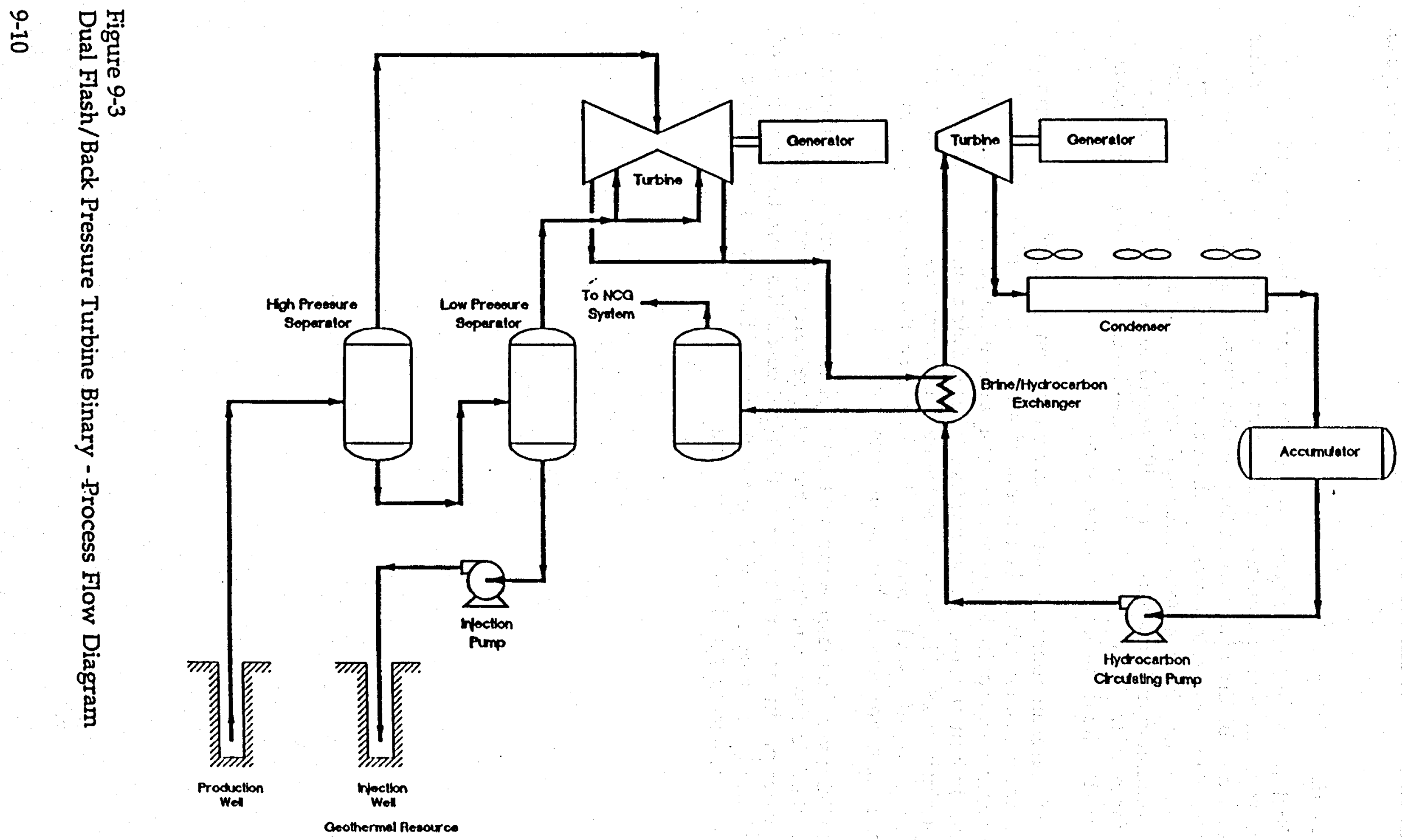

C

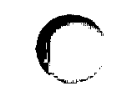


Flash Pressure Optimization, Glass Mountain

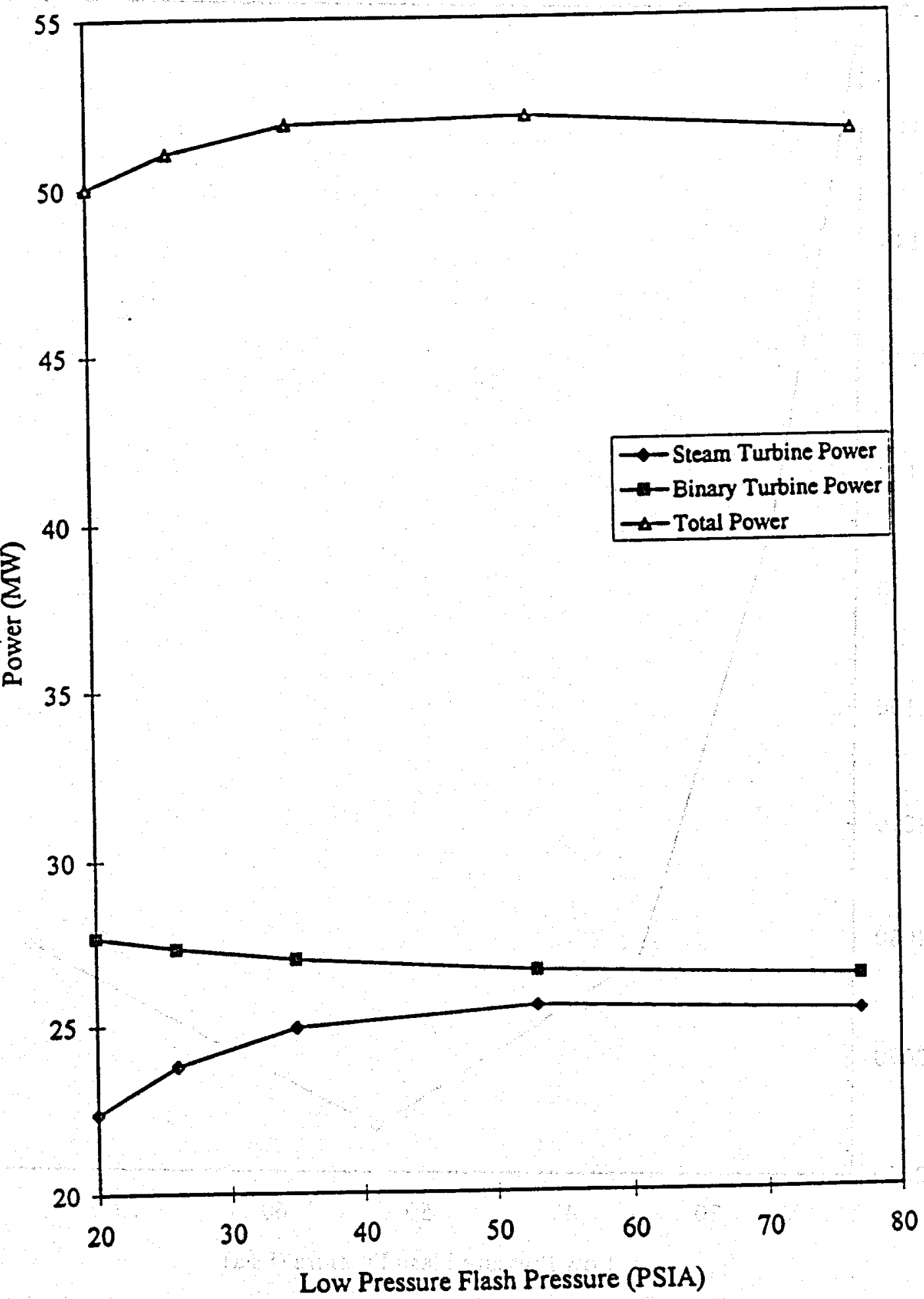

Figure 9-4

DFBPT: Flash Pressure Optimization, Glass Mountain 


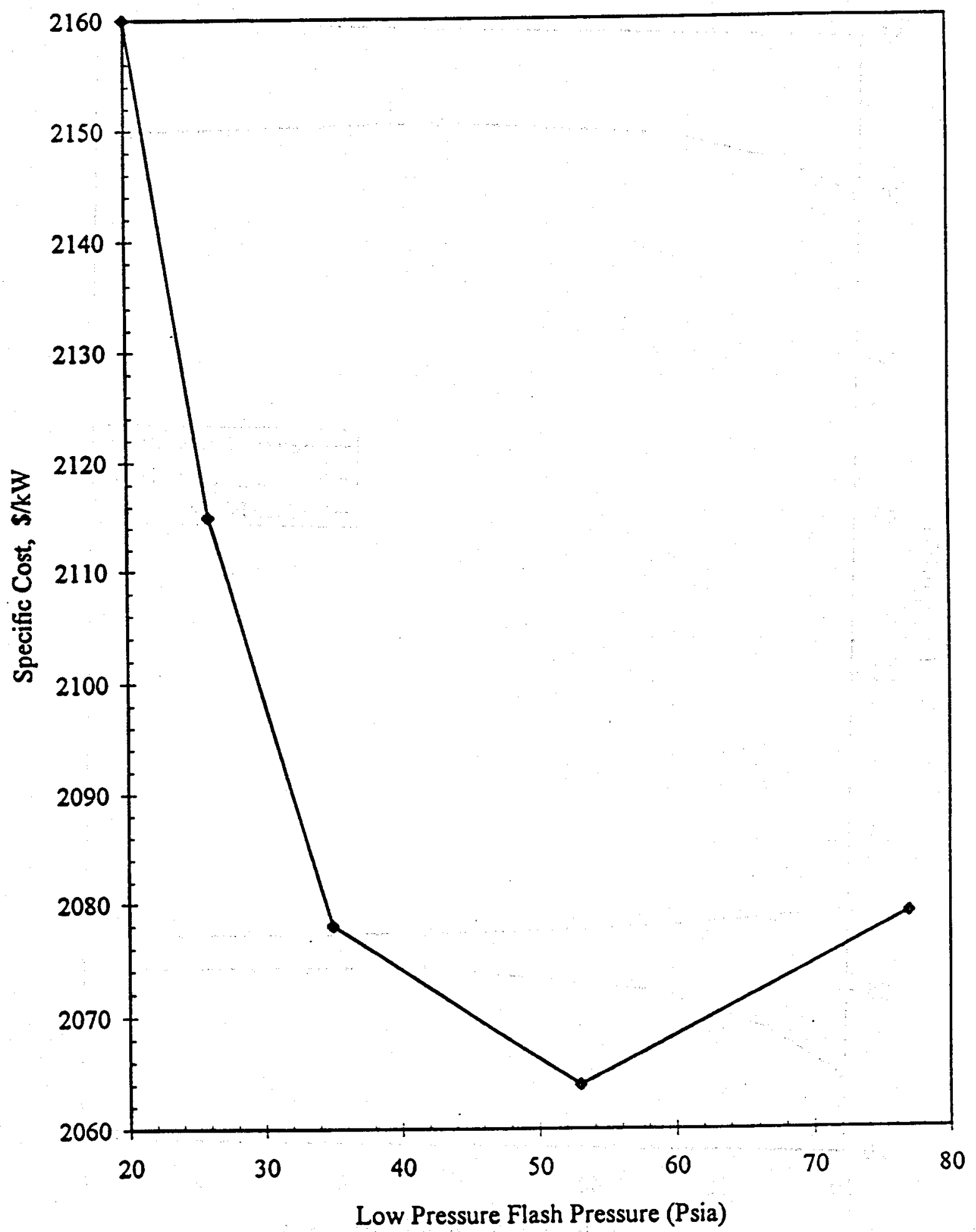

Figure 9-5

DFBPT: Specific Plant Cost v. LP Flash Pressure, Glass Mountain 


\section{Table 9-2}

\section{Dual Flash/Back Pressure Turbine Binary - Major Equipment Costs}

Subject: Back Pressure Turbine Cycle, Economic Optimum Cases

\begin{tabular}{|c|c|c|c|c|c|}
\hline & & & & & \\
\hline Power Plant & $\begin{array}{l}\text { Glass Mtn } \\
510^{\circ} \mathrm{F}\end{array}$ & $\begin{array}{l}\text { Coso } \\
525^{\circ} \mathrm{F}\end{array}$ & $\begin{array}{l}\text { Desert PK } \\
425^{\circ} \mathrm{F}\end{array}$ & $\begin{array}{l}\text { Surprise V } \\
375^{\circ} \mathrm{F}\end{array}$ & $\begin{array}{l}\text { Vale, Oregon } \\
\quad 330^{\circ} \mathrm{F}\end{array}$ \\
\hline 1200 H.P. Separators & 101,248 & 107.802 & 143,397 & 127,200 & 253,800 \\
\hline L.P.Separators & 53,600 & 53,600 & 70,000 & 140,000 & 165,000 \\
\hline Purifiers & 31,600 & 28,300 & 32,000 & 46,300 & 65,900 \\
\hline Silencers & 22,500 & 22,500 & 22,500 & 22,500 & 22,500 \\
\hline 1300 Condenser & 0 & 0 & 0 & 0 & $\mathbf{0}$ \\
\hline 1500 Hot Well/Cond. Pumps & 0 & 0 & 0 & 0 & 0 \\
\hline Fire Pumps & 55,000 & 55,000 & 55,000 & 55,000 & 55,000 \\
\hline L. O. Trans. Pumps & 4,000 & 4,000 & 4,000 & 4,000 & 4,000 \\
\hline Pot. Water Pumps & 7,000 & 7,000 & 7,000 & 7,000 & 7,000 \\
\hline Aux. C.W. Pumps & 0 & $\mathbf{0}$ & 0 & 0 & 0 \\
\hline Injection Pumps & 85,400 & 85,400 & 113,000 & 181,600 & 281,400 \\
\hline 1700 Cooling Tower & 0 & 0 & 0 & 0 & 0 \\
\hline 1800 Plant Air System & 63,500 & 64,200 & 47,000 & 33,900 & 15,900 \\
\hline 1900 L. O. Storage Tanks & 29,000 & 29,000 & 29,000 & 29,000 & 29,000 \\
\hline 2800 Turbine Generator & $8,787,000$ & $9,132,000$ & $7,908,000$ & $7,945,000$ & $7,426,000$ \\
\hline NCG Compressor & 425,394 & $2,578,985$ & 135,114 & $2,125,914$ & $3,092,680$ \\
\hline Gantry Crane & 500,000 & 500,000 & 500,000 & 500,000 & 500,000 \\
\hline Vac Hot Well & 0 & 0 & 0 & 0 & 0 \\
\hline Sulfur Plant & 0 & 0 & 0 & 0 & 0 \\
\hline Misc. Tanks & 103,000 & 128,000 & 91,000 & 113,000 & 119,000 \\
\hline Start-up or Emer Gen. & 31,000 & 31,000 & 31,000 & 31,000 & 31,000 \\
\hline FW Tank + Sys & 125,000 & 125,000 & 125,000 & 125,000 & 125,000 \\
\hline Total Major Equipment & $10,820,603$ & $13,386,915$ & $9,671,645$ & $11,874,219$ & $12,580,554$ \\
\hline Total Flash Plant Cost & $27,376,000$ & $33,869,000$ & $24,469,000$ & $30,042,000$ & $31,829,000$ \\
\hline iathering \& Injection System & & & & & \\
\hline 1500 Production Pumps & & & 0 & $1,559,149$ & $2,551,335$ \\
\hline Prod. Pump Aux. & $\mathbf{0}$ & 0 & 0 & 79,200 & 129,600 \\
\hline 2800 Silencers & 25,000 & 25,000 & 25,000 & 25,000 & 25,000 \\
\hline Total Major Equipment & 25,000 & 25,000 & 25,000 & $1,663,349$ & $2,705,935$ \\
\hline Total & 53,000 & 53,000 & 53,000 & $3,510,000$ & $5,710,000$ \\
\hline Summary CASE & Glass Mtn & Coso & Desert Pk & Surprise V & Vale, Oregon \\
\hline $\begin{array}{l}\text { Plant Equip. Cost } \\
\text { Total Flash Plant Equip Cost }\end{array}$ & $\begin{array}{l}10,820,603 \\
27,376,000\end{array}$ & $\begin{array}{l}13,386,915 \\
33,869,000\end{array}$ & $\begin{array}{r}9,671,645 \\
24,469,000\end{array}$ & $\begin{array}{l}11,874,219 \\
30,042,000\end{array}$ & $\begin{array}{l}12,580,554 \\
31,829,000\end{array}$ \\
\hline Total Gath \& Injec Equip Cost & 53,000 & 53,000 & 53,000 & $3,510,000$ & $5,710,000$ \\
\hline Total Binary Plant Cost & $50,740,312$ & $48,829,196$ & $51,014,294$ & $76,564,344$ & $100,071,439$ \\
\hline Gath \& Injec Piping Cost & $1,733,000$ & $1,540,000$ & $1,486,000$ & $1,084,000$ & $1,248,000$ \\
\hline Well Cost & $27,500,000$ & $22,000,000$ & $23,765,060$ & $31,000,000$ & $45,264,706$ \\
\hline Grand Total & $107,402,312$ & $106,291,196$ & $100,787,354$ & $142,200,344$ & $184,123,145$ \\
\hline $\begin{array}{l}\mathbf{\$} / \mathbf{k W} \text { (Flash) } \\
\mathbf{\$} / \mathbf{k W}\end{array}$ & $\begin{array}{l}2,220 \\
2,062\end{array}$ & $\begin{array}{l}2,225 \\
2,137\end{array}$ & $\begin{array}{l}2,631 \\
2,151\end{array}$ & $\begin{array}{l}4,812 \\
2,565\end{array}$ & $\begin{array}{r}13,180 \\
2,983\end{array}$ \\
\hline
\end{tabular}


Hybrid Cycles

\section{Dual Flash/Gas Turbine Hybrid}

\section{Introduction}

Dual flash - gas turbine hybrid power plants combine geothermal power production with fuel burning power production to increase the efficiency of each process over independent operation. What is otherwise waste heat from the gas turbine exhaust is transferred to the geothermal fluid to increase the enthalpy available.

\section{Cycle Process Flow}

Several types of dual flash-gas turbine hybrid plants were investigated, and process flow diagrams for the two best alternatives are shown on Figures 9-6 and 9-7. All the hybrid plants use natural gas turbines. The dual flash portion of the plant is the same as described previously with the addition of one heat exchanger in each case. For the resources which require pumping, those below $400{ }^{\circ} \mathrm{F}$, the gas turbine exhaust heats the liquid resource several ${ }^{\circ} \mathrm{F}$ before it enters the high pressure separators. The free flowing resources, those above $400^{\circ} \mathrm{F}$, employ a heat recovery steam generator (HRSG) which makes additional high pressure steam from the condensate.

\section{Performance Analysis}

\section{Description}

The same gas turbine unit is used at each site, a G.E. LM2500. This unit produces roughly $20 \mathrm{MW}$, or forty percent, of the total net power for the hybrid plant. By choice, the majority of the power is produced by the geothermal part of the plant. The net power output, fuel consumption, exhaust gas enthalpy and exhaust gas flow rate for the LM2500 are found from curves published by G.E. These values are a function of atmosphere pressure and ambient weather conditions. Since in this study the wet bulb and dry bulb temperatures are assumed to be constant, the power output of the gas turbine and the enthalpy available in the exhaust gas are constant at each site. The remaining task is to utilize the exhaust gas heat and the minimum amount of brine to produce a fixed remainder of power at each site.

A process simulator was used to make preliminary investigations of a number of processes for adding the exhaust gas heat to the geothermal cycle. From these investigations it was found that the best performing cycle for the pumped resources involves heating the brine before it enters the high pressure separators. This effectively increases the enthalpy of the resource.

The free flowing resources have the high pressure separators located out on the well pads. It is not possible to use the exhaust gas from the gas turbine, which is located in the main plant, to supply heat to the fluid entering the 
high pressure separators. To minimize the technical risk associated with adding this heat, cycles involving superheating geothermal steam or vaporizing geothermal brine were eliminated. The superheated geothermal steam would be highly corrosive and an exhaust gas-to-superheated steam exchanger would have poor heat transfer requiring excessive surface area. Vaporizing geothermal brine would cause excessive fouling as the dissolved solids plate out on the heat exchanger.

Table 9-3 summarizes the alternatives that were considered for the free flowing cases. Option one involves heating the low pressure brine. Option two involves heating the turbine condensate. Option three, involves heating a portion of the entire condensate to high pressure steam. Option three produces the most power. It is also the simplest alternative, employing a standard HRSG as the heat exchanger. Therefore, option three was used for the free flowing cases

\section{Assumptions}

- The assumptions for hybrid analysis are consistent with those for conventional dual flash analysis for similar process components.

- The exhaust gas exit temperature was limited to $260^{\circ} \mathrm{F}$ to limit condensation.

- There was a $30^{\circ} \mathrm{F}$ limit on the approach temperature for the HRSG. This is approximately an economic optimum.

\section{Cost Analysis}

\section{Description}

The capital cost of the LM2500 was assumed to be fixed at $\$ 8,600,000$ which is based on a quote from G.E. The costs of the HRSG and the brine heater were found as a function of surface area as are all heat exchangers in the study. The installed cost multiplier for these pieces is 2.53 just as with dual flash equipment. The optimum plant is defined as one which produces the fixed remainder ( $50 \mathrm{MW}$ net minus the gas turbine power) power for the lowest capital cost.

\section{Assumptions}

- The cost assumptions were consistent with those made in the dual flash economic analysis for similar equipment.

- The installed cost multiplier for the LM2500, the HRSG, and the brine heater was 1.8 as opposed to 2.53 for other dual flash equipment. 
Hybrid Cycles

\section{Results}

\section{Performance}

Referring to table 5-6, the vacuum system that is most economical at each site for the conventional dual flash cases is also best for the hybrid plants. The geothermal part of the hybrid plants, with the exception of Thermo Hot Springs, can produce the $30 \mathrm{MW}$ of power with a single turbine. Only one turbine is needed for the colder hybrid plants because only half the steam flow is required.

The dual flash portion of the hybrid plants use roughly half of the flow of the full scale plant yet produce over 60 percent of the net power. This is approximately true for all of the resources. The added heat from the gas turbine exhaust produces roughly a twenty percent increase in brine utilization. Figure 9-8 shows the specific output comparison.

\section{Economics}

It is inappropriate to compare the specific capital cost of these hybrids to other technologies because of the fuel requirements. Only comparison of the levelized busbar costs is significant. This is done in Section 11. 

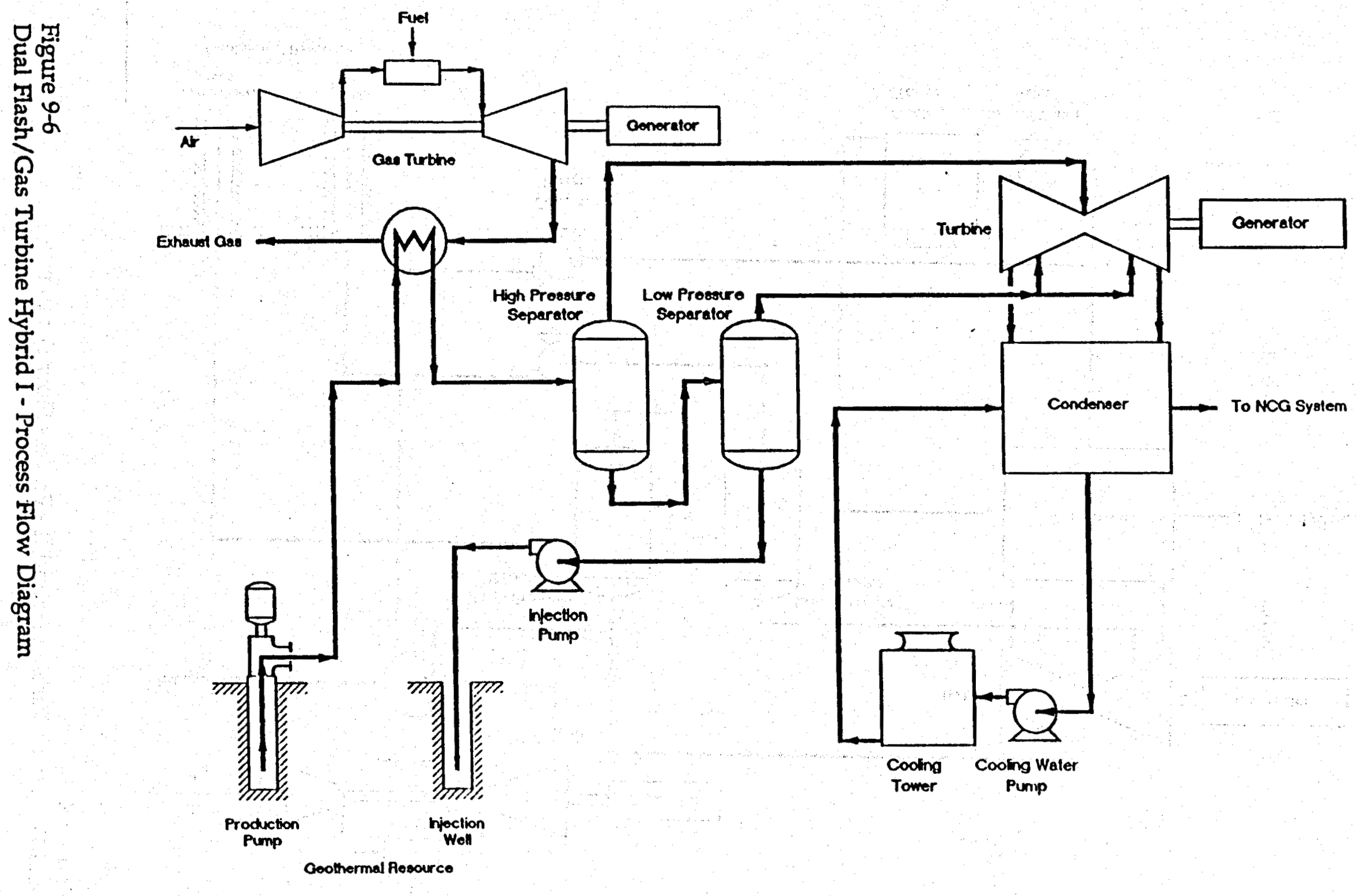

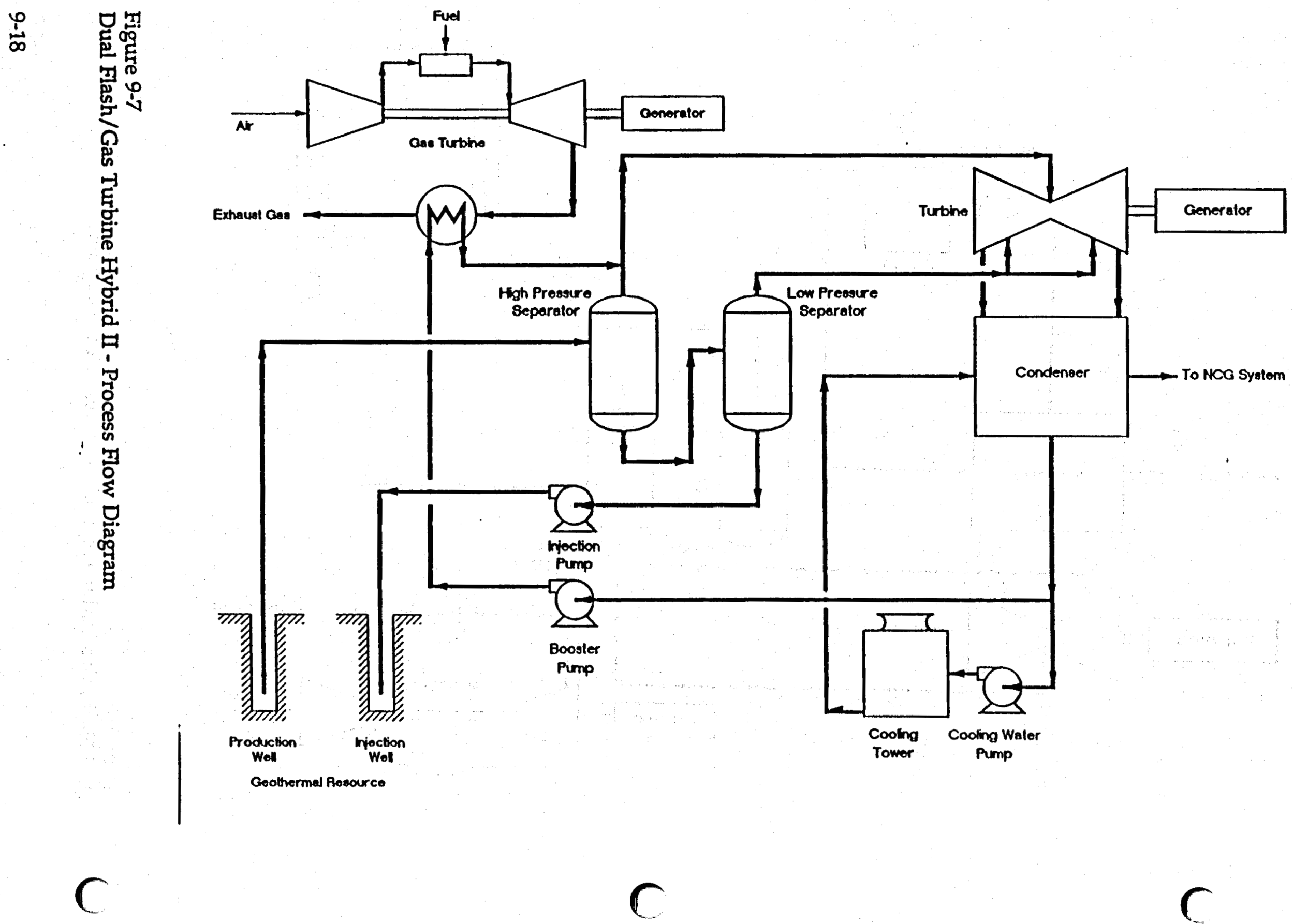


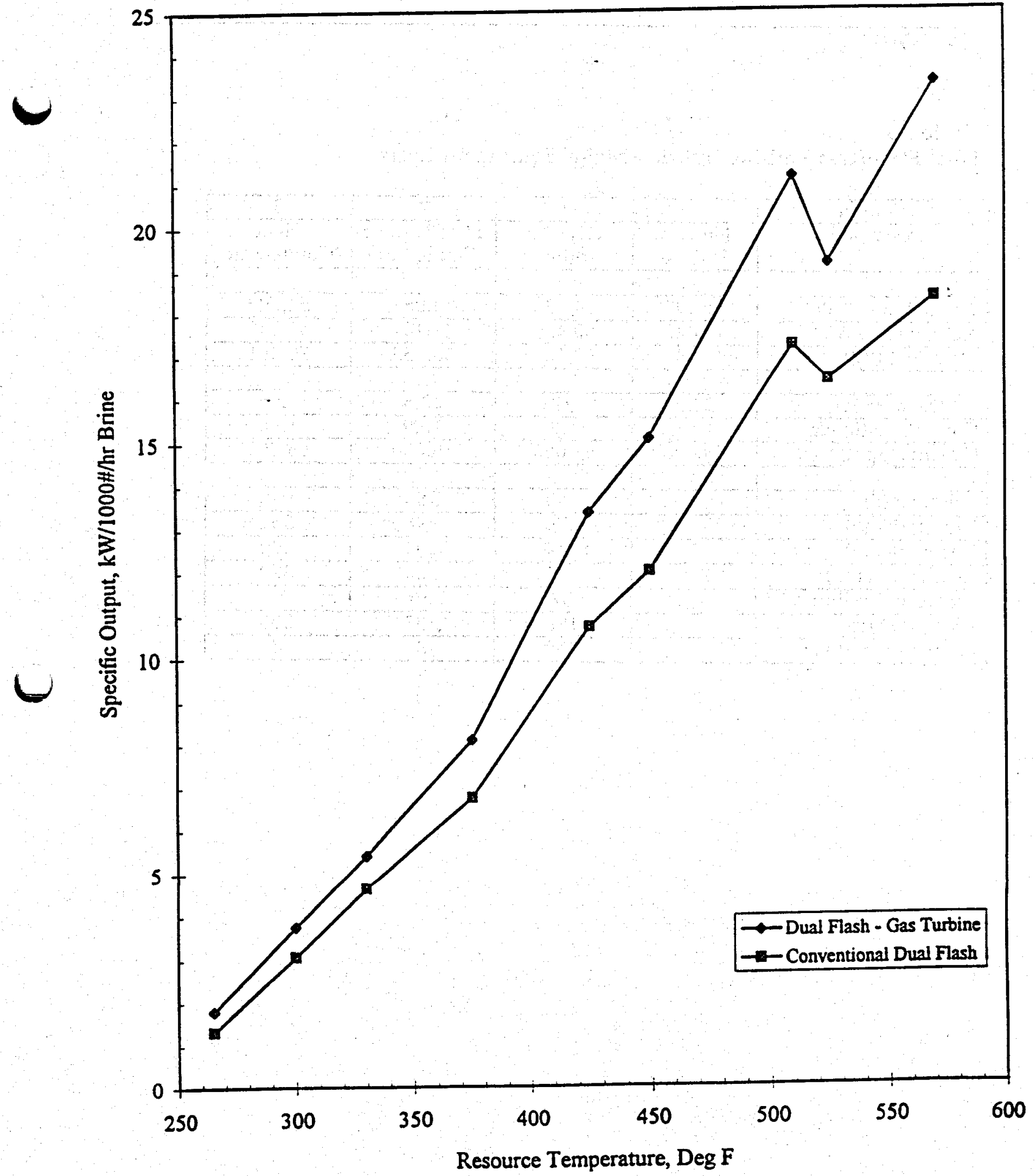

Figure 9-8

Dual Flash/Gas Turbine Hybrid - Specific Output v Resource 
Table 9-3

Dual Flash/Gas Turbine Hybrid - Major Equipment Costs

\begin{tabular}{|l|c|c|c|c|}
\hline \multicolumn{1}{|c|}{ Option } & & 1 & 2 & 3 \\
\hline Description & $\begin{array}{c}\text { No Gas } \\
\text { Turbine }\end{array}$ & $\begin{array}{c}\text { Heat LP } \\
\text { Brine }\end{array}$ & $\begin{array}{c}\text { Heat Turbine } \\
\text { Condensate }\end{array}$ & $\begin{array}{c}\text { Heat } \\
\text { Condensate }\end{array}$ \\
\hline Gross Power (kW) & 51,092 & 54,138 & 53,057 & 54,809 \\
\hline Net Power (kW) & 48,047 & 50,450 & 49,461 & 51,349 \\
\hline Plant Net (kW) & 48,047 & 69,162 & 68,353 & 70,061 \\
\hline & & & & 22.5 \\
\hline LP Flash (psia) & 22.5 & 27 & 22.5 & 1.96 \\
\hline Cond Press (in Hg) & 1.86 & 1.9 & 1.89 & 66,500 \\
\hline CT Circ. (gpm) & 56,000 & 67,000 & 66,000 & \\
\hline & & & & 980 \\
\hline Exh Inlet (F) & & 980 & 980 & 352 \\
\hline Exh Outlet (F) & & 274 & 698 & 100 \\
\hline Geoth Inlet (F) & & 244 & 234 & 320 \\
\hline Geoth Outlet (F) & & 344 & 320 & 78 \\
\hline Hx Duty (MMBtu/h) & & 87 & 36 & 305 \\
\hline Hx LMTD (F) & & 198 & 593 & 3 \\
\hline Pump Power (kW) & & 229 & & 8 \\
\hline
\end{tabular}




\section{Binary/Gas Turbine Hybrid}

\section{Introduction}

In this hybrid concept, exhaust gas from a natural gas fired combustion turbine is used to provide additional heat input to the binary cycle working fluid. The addition of high temperature exhaust heat increases the thermodynamic efficiency of the binary cycle operating on a relatively low temperature geothermal fluid.

\section{Cycle Process Flow}

As in the dual flash/ gas turbine hybrid cycle, the gas turbine is a General Electric LM 2500. Since this is a study of geothermal cycles, a decision was made that less than half of the power should be produced from a fossil fuel source. A GE LM 2500 is the largest standard frame size to meet this criteria. The binary cycle employs air-cooled condensers for heat rejection. Air-cooled condensers allow operation in arid locations where cooling water is unavailable and in environmentally sensitive areas where cooling tower discharge is unacceptable. Commercial isobutane was used as the working fluid for all the binary cycles.

Figure 9-9 shows a process schematic for the binary/ gas turbine hybrid with the binary and exhaust gas exchangers in series. In this cycle, cold isobutane is heated and partially vaporized in the geothermal fluid-to-isobutane exchanger and then heated to turbine inlet conditions in the exhaust gas-toisobutane exchanger. Figure $9-10$ shows a cycle in which the cold isobutane is heated to its bubble point in a brine preheater. After leaving the brine preheater, the isobutane flow splits with some of the isobutane being boiled in the exhaust gas-to-isobutane vaporizer and some in the geothermal fluidto-isobutane vaporizer. Both the series and parallel heat exchanger configurations were considered in this study. Figure 9-11 shows a temperature - enthalpy diagram for Thermo Hot Springs of the series heat exchanger configurations. Figure 9-12 shows a temperature - enthalpy diagram for Thermo Hot Springs of the parallel heat exchanger configurations.

\section{Assumptions}

For all cases, the combined power output of the binary and gas turbine portion of the plant was set at $50 \mathrm{MW}$. Cycle and economic analysis of the binary/gas turbine hybrid were performed for the low temperature resources where a binary cycle is favored over dual flash (Thermo Hot Springs, Raft River, Vale and Surprise Valley). 


\section{Performance Analysis}

Gas turbine data are usually given at ISO conditions of $59^{\circ} \mathrm{F}$ and sea level. For this study, gas turbine power production, fuel consumption and exhaust gas flow were adjusted for site conditions.

Binary cycle assumptions were maintained the same as for the stand alone binary cycles. These assumptions are detailed in Section 5. A 50 psi pressure drop from the discharge of the hydrocarbon circulating pump to the turbine inlet was maintained. Due to pressure drop through the exhaust gas-to-brine heat exchanger, a 10 inch water back pressure on the combustion gas turbine was used. Standard HRSGs used in combined cycle plants also have a pressure drop of 10 inch water. The minimum temperature difference between the exhaust gas and the isobutane was set at $30^{\circ} \mathrm{F}$ and the minimum exhaust gas temperature was set at $260^{\circ} \mathrm{F}$ to limit condensation.

\section{Economic Analysis}

Binary cycle cost assumptions were same as those listed in Section 5. GE provided a budget price of $\$ 8,600,000$ for the natural gas turbine package. A vendor quoted a price of $\$ 1,077,500$ for an exhaust gas exchanger with a duty of $902 \mathrm{MMBtu} / \mathrm{h}$ and a weighted log mean temperature difference of $223{ }^{\circ} \mathrm{F}$. An installation multiplier of 1.8 was used for the combustion turbine and exhaust gas exchanger.

\section{Results}

Depending on site elevation, the combustion gas turbine produces between 18 to $19 \mathrm{MW}$. The binary cycle produces the remainder. Table 9-4 shows the specific output of the binary portion of the plant. Addition of exhaust heat increases brine utilization 22\% at Thermo Hot Springs, 25\% at Raft River and $7 \%$ at Surprise Valley. Addition of high temperature exhaust gas has a larger impact on cycle efficiency for low temperature resources where thermodynamic efficiency is inherently lower. Table 9-5 shows percentage of heat input to the binary cycle that comes from the exhaust gas. At Thermo Hot Springs, the percentage of heat input from exhaust gas is lower than for Raft River so specific power output increases less at Thermo Hot Springs than at Raft River with the addition of the exhaust gas.

For low temperature resources, a plant with parallel heat exchangers has both higher specific power output and lower cost than one with a series heat exchanger arrangement. For low temperature subcritical cycles, parallel arrangement changes the pinch point and allows a higher turbine inlet pressure. For supercritical cycles, heat is better utilized by adding the hottest heat source to the hottest portion of the cycle.

Table 9-6 shows total plant cost for both binary/natural gas hybrid plants and binary plants. Capital cost of hybrid plants is significantly lower due to the lower first cost of the combustion turbine. GE turbine cost is about $\$ 865 / \mathrm{kW}$. 
The economically preferred generation technology is determined by the levelized busbar cost which includes natural gas fuel costs. Levelized busbar costs for the various technologies are discussed in Section 11. 


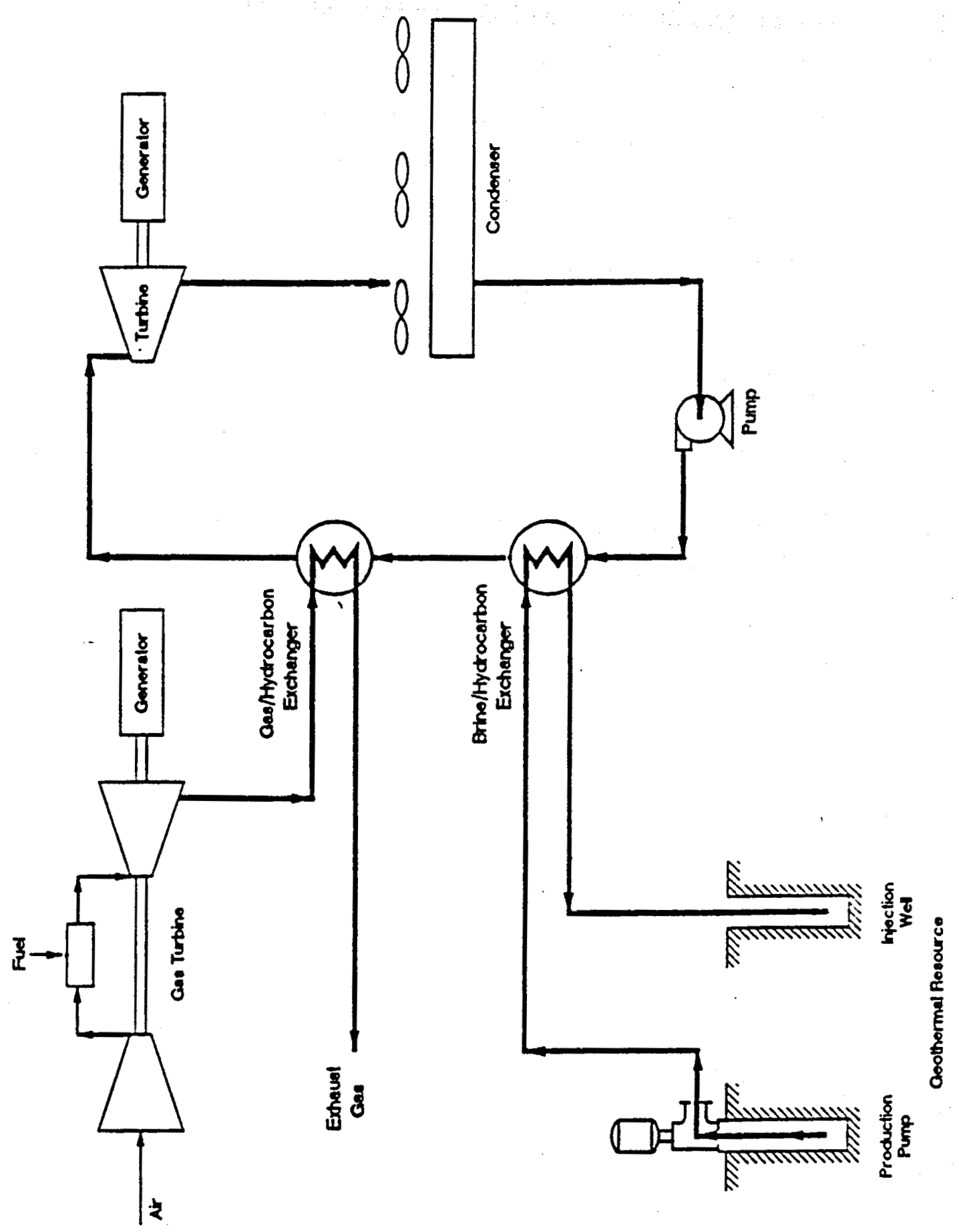

Figure 9-9

Gas Turbine - Binary Hybrid I Process Flow-Diagram 


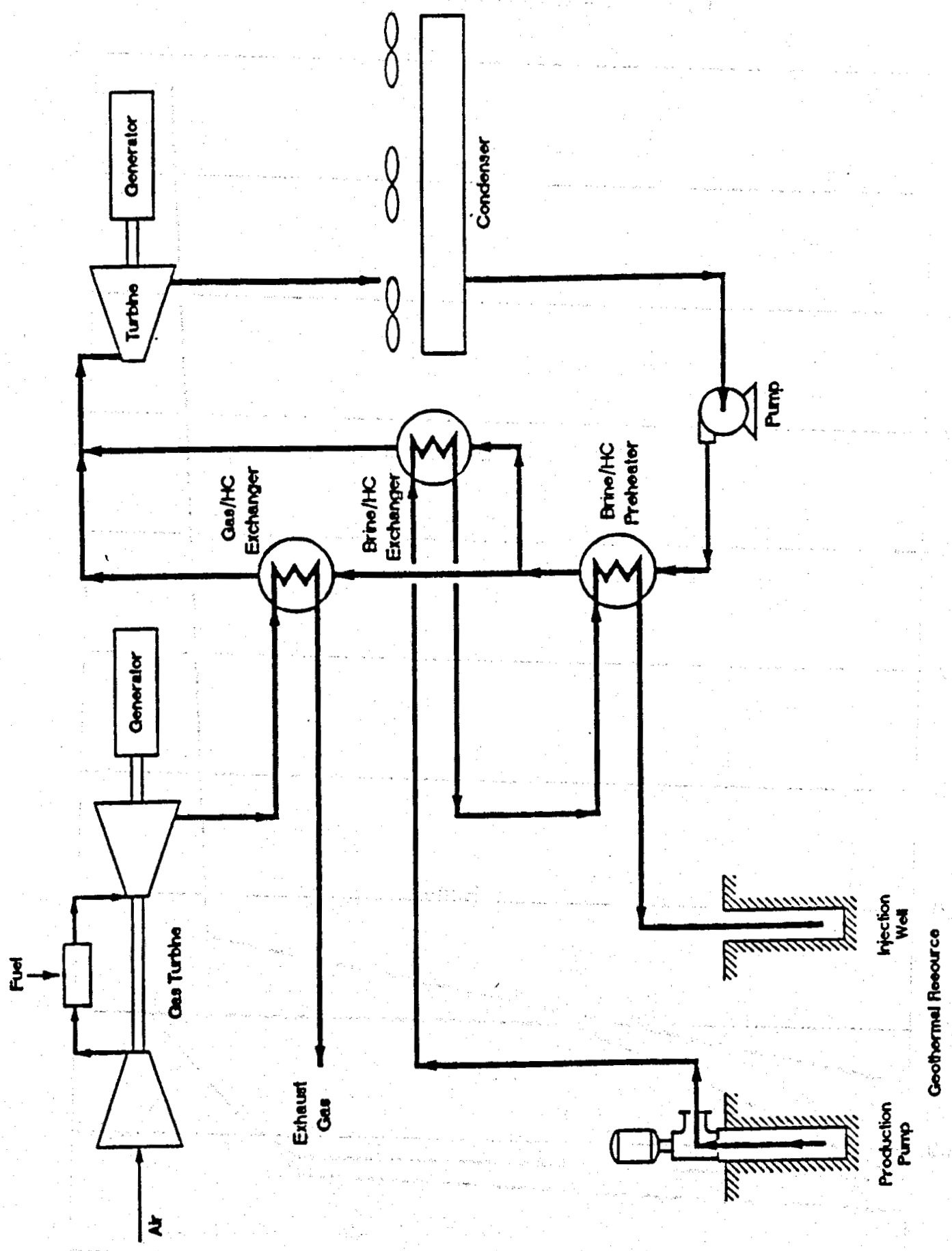

Figure 9-10

Gas Turbine - Binary Hybrid II Process Flow -Diagram 
Thermo Hot Śprings

Exchangers in Series

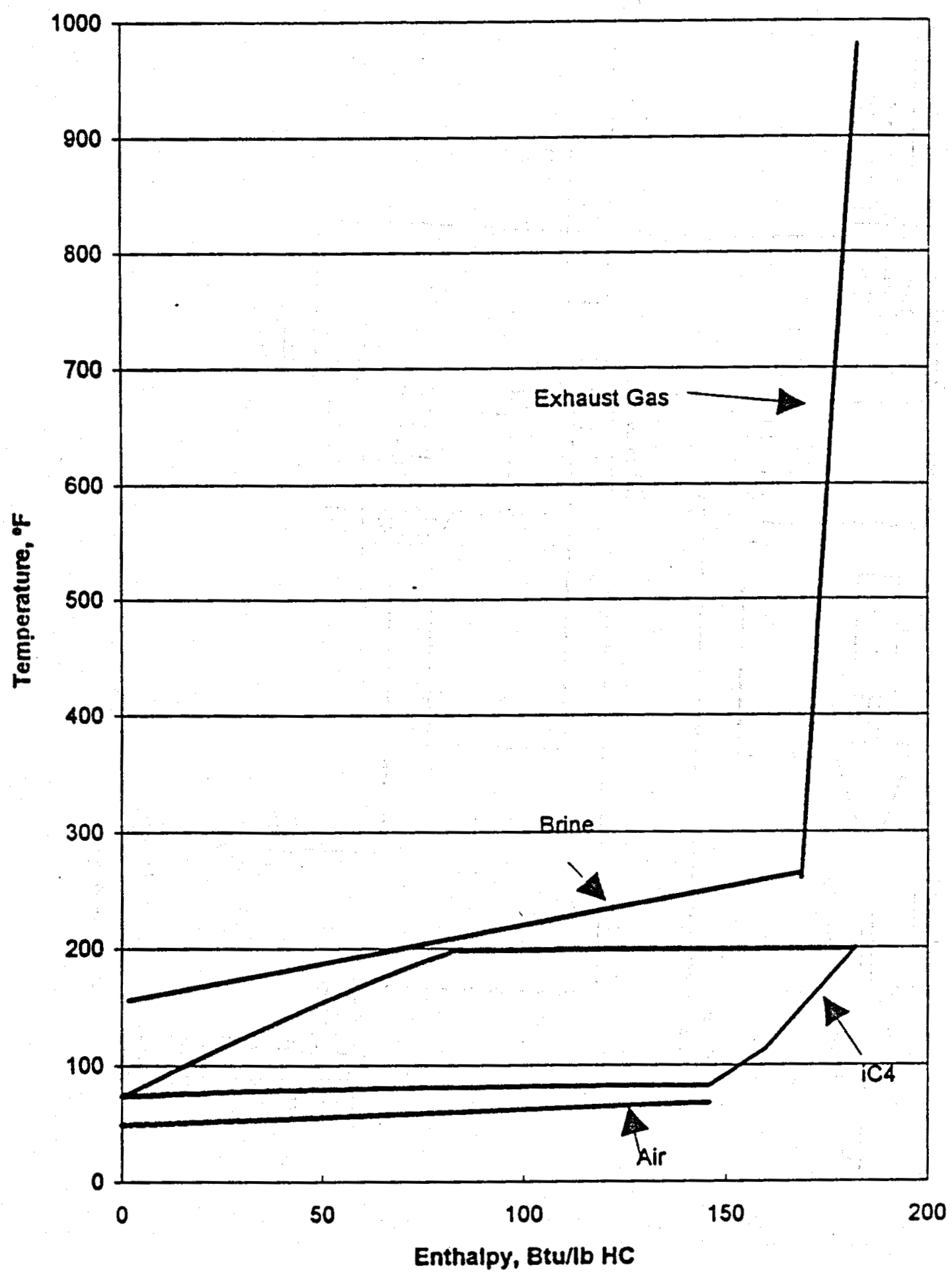

Figure 9-11

Temperature-Enthalpy Diagram: Heat Exchangers in Series 
Thermo Hot Springs

Exchangers in Parallel

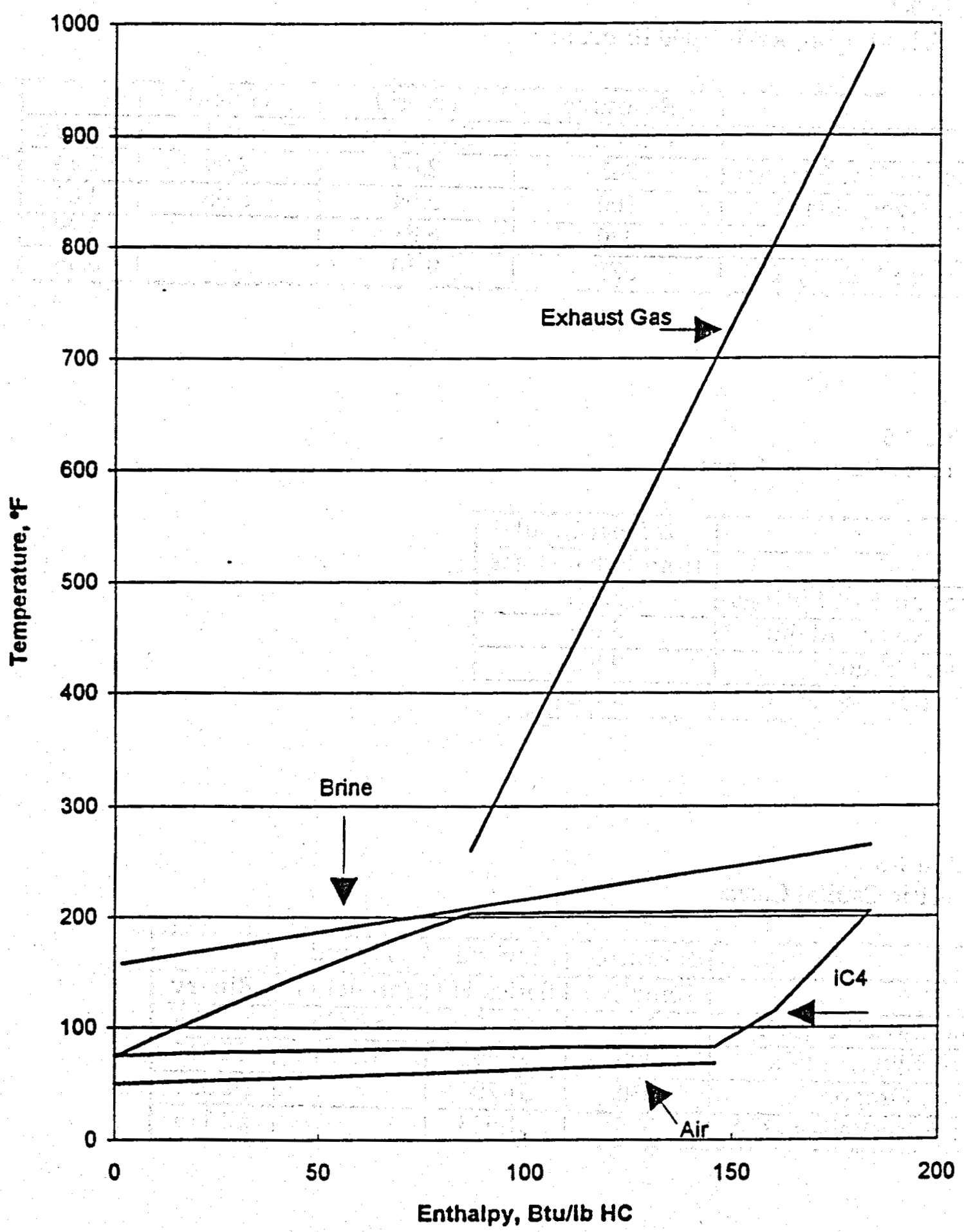

Figure 9-12

Temperature-Enthalpy Diagram: Heat Exchangers in Parallel 
Table 9-4

Specific Output, kWh/ 1000 lb brine

\begin{tabular}{|l|c|c|c|c|}
\hline & Resource & Hybrid & Hybrid & \\
\hline & Temp., $^{\circ} \mathrm{F}$ & Series Hx & Parallel Hx & Binary \\
\hline Thermo Hot Springs & 265 & 2.69 & 2.99 & 2.44 \\
\hline Raft River, Idaho & 300 & 5.04 & 5.05 & 4.04 \\
\hline Vale, Oregon & 330 & 6.81 & & 5.99 \\
\hline Surprise Valley, CA & 375 & 9.10 & & 8.49 \\
\hline
\end{tabular}

Table 9-5

Exhaust Gas Heat Input

\begin{tabular}{|l|c|}
\hline & \% Heat Input \\
\hline & from Exhaust gas \\
\hline Thermo Hot Springs & $5.8 \%$ \\
\hline Raft River, Idaho & $8.6 \%$ \\
\hline Vale, Oregon & $9.8 \%$ \\
\hline Surprise Valley, CA & $9.6 \%$ \\
\hline
\end{tabular}

Table 9-6

\section{Specific Capital Costs}

\begin{tabular}{|l|c|c|c|c|}
\hline & Resource & Hybrid & Hybrid & \\
\hline & Temp., ${ }^{\circ} \mathrm{F}$ & Series Hx & Parallel Hx & Binary \\
\hline Thermo Hot Springs & 265 & $\$ 2,763$ & $\$ 2,726$ & $\$ 4,188$ \\
\hline Raft River, Idaho & 300 & $\$ 1,961$ & $\$ 1,964$ & $\$ 2,945$ \\
\hline Vale, Oregon & 330 & $\$ 1,704$ & & $\$ 2,356$ \\
\hline Surprise Valley, CA & 375 & $\$ 1,528$ & & $\$ 2,115$ \\
\hline
\end{tabular}




\section{0}

\section{ENVIRONMENTAL IMPACT}

\section{Introduction}

Although geothermal power plants are typically benign compared to other energy resources when it comes to environmental impact, there are some differences between the various technologies that should be understood and evaluated. Since the overall environmental impact is usually low, this is a secondary criterion in comparing technologies.

Since all of the technologies are geothermal power plants, we can expect that they will all have roughly the same impact in a number of environmental areas. In this section, we first discuss those areas for which all of the technologies have the roughly the same environmental impact. Next, we examine the areas for which different technologies have significantly different environmental impacts. Once we have determined the varying environmental impacts, we rank the technologies against each other.

\section{Technology Independent Impacts}

\section{Earth}

At the surface, construction of a geothermal power plant will change the topography of the site. Operations such as grading will serve to disrupt, displace, and compact the soil. Although geothermal plants are a clean alternative to many other forms of energy production, surface runoff containment is necessary to prevent any contamination of surrounding soil.

The effects of operating a plant may also be seen below the surface. The brine is cooled and moved from the production well areas to the injection well areas. This movement of brine has the potential to cause subsidence. Subsidence would be of concern if the sagging were to damage structures in the area. In some cases it is necessary to add chemicals to alter the $\mathrm{pH}$ of the brine to prevent scaling. This could then alter the $\mathrm{pH}$ of the reservoir.

All of the technologies we have investigated have roughly the same potential to impact the surrounding earth. 


\section{Plant and Animal Life}

Construction of a geothermal power plant would, as would any kind of construction project, impact the plant and animal life in the area. It would result in the destruction of a small amount of habitat, and disrupt the lives of a few organisms. However, it is not inherent in any of the geothermal technologies to do the following: change the diversity of species, reduce the number of an endangered species, or introduce a new species to an area.

\section{Noise}

Each type of technology has pumps, turbines, cooling fans, vents, etc. All of these would contribute to a steady drone of background noise. One type of technology would not be significantly noisier than another. The degree of impact of this noise would vary with the proximity of the plant to human population. Often, geothermal plants are located in remote regions.

\section{Light and Glare}

Geothermal power plants operate around the clock. It is therefore necessary that they be well lit to allow routine operation and inspection at night. This light would be noticeable in the surrounding area, and would not vary significantly from one technology to another. The extent of the impact would depend upon the proximity of the plant to human population.

\section{Land Use}

The main plant would take up from 5 to 10 acres of land. The gathering and injection systems would finger out for up to several miles in all directions. Fifty miles or more of transmission lines are often required to deliver the electric power to its consumers. In some cases, roads must be built or expanded to accommodate construction traffic. For a $50 \mathrm{MW}$ plant, this land use would not vary significantly from technology to technology at a given site.

\section{Population}

A power plant would increase population by adding to the area people who construct and then run the plant. This additional population would require housing, transportation, utilities, and public services. The degree to which this would impact an area would depend upon the existing population. All of the technologies would have roughly the same impact on population.

\section{Recreation}

A geothermal power plant might impact outdoor recreation activities. A branching gathering and injection system might serve as a barrier to hunters, hikers, or off road motorists. Many geothermal sites have natural spas in 
their proximity that might be depleted. All of the technologies have roughly the same potential to impact recreation in these ways.

\section{Archaeological/Historical}

It is possible that the site chosen for a geothermal power plant could contain fossils, or ruins or other items of archeological interest. It is also possible that the sites contain structures or landmarks of historical interest. This type of potential impact would not be affected by the type of technology in use.

\section{Alr Pollution}

Air pollutant emissions are perhaps the most noteworthy potential environmental impact of geothermal power plants. The quantities and type of emissions vary from one technology to another.

Flash plants and their variations are open cycles. In an open cycle plant, the geothermal fluid is exposed to the atmosphere during the process. The result is that the plants can emit nearly all of the noncondensable gas from the brine into the air. The open cycle technologies include, advanced flash, sub atmospheric flash, rotary separator turbine, and flash hybrids.

We refer to the standard dual flash process flow diagram Figure 5-9 to follow the path that the gas travels. The gas begins dissolved in the brine and then travels from the brine into the steam when the brine is flashed. It then goes through the turbine and into the condenser. Some of the gas leaves the condenser in the liquid condensate and goes to the cooling tower with the cooling water. A flash plant that uses a direct contact condenser instead of a surface condenser will have a greater quantity of gas in the cooling water return. This is because there will be up to 40 times more liquid contacting the gas than in a surface condenser. In either case, most of the gas is pulled out of the condenser by the vacuum system. The gas is then compressed to slightly above atmospheric pressure and may be sent to a sulfur plant. The discharge from the sulfur plant is usually vented to the atmosphere.

Hydrogen sulfide $\left(\mathrm{H}_{2} \mathrm{~S}\right)$ is the most hazardous constituent of the noncondensable gas stream. It is colorless with a strong odor. It is heavier than air and will settle in low lying areas. Hydrogen sulfide can be instantly fatal if inhaled in high concentrations. Exposures of 800 to $1000 \mathrm{ppm}$ can be fatal in 30 minutes. In concentrations of 20 to $150 \mathrm{ppm}$, hydrogen sulfide acts as a respiratory irritant by combining with alkali present in moist tissues to form sodium sulfide, a caustic. Because of its potential toxicity, the $\mathrm{H}_{2} \mathrm{~S}$ in the noncondensable gas stream usually converted to elemental sulfur by a small sulfur plant. In this study, we size the sulfur plants to handle all but 11 pounds per hour of the $\mathrm{H}_{2} \mathrm{~S}$ in the brine. We assume that in a worst case 
scenario with no oxidation in the cooling tower, the remaining eleven pounds per hour are emitted to the atmosphere. This is consistent with the $100 \mathrm{~g}$ per MW hour limit placed on an actual operating plant in California.

Carbon dioxide $\left(\mathrm{CO}_{2}\right)$ is the most abundant constituent in the noncondensable gas stream. In the cases we examine, we assume that $\mathrm{CO}_{2}$ comprises over 98 percent of the noncondensable gas. Although it is not acutely hazardous, concerns about the greenhouse effect make $\mathrm{CO}_{2}$ emissions an issue. The open cycle NCG emissions tables show the amount of $\mathrm{CO}_{2}$ released by each open cycle technology at each site. We see that the quantity of $\mathrm{CO}_{2}$ emissions at a given site is directly proportional to brine utilization, with emissions decreasing as brine utilization improves.

Ammonia $\left(\mathrm{NH}_{3}\right)$, hydrogen $\left(\mathrm{H}_{2}\right)$, and methane $\left(\mathrm{CH}_{4}\right)$ are other common trace constituents in geothermal brine. In our economic analysis, we do not make any assumptions as to the concentrations of these species in the brine. Generally, the ammonia concentrations are less than that of $\mathrm{H}_{2} \mathrm{~S}$ but on the same order of magnitude. The others are found in one tenth the concentration of $\mathrm{H}_{2} \mathrm{~S}$ or smaller. The trends for emission of $\mathrm{CO}_{2}$ shown in the open cycle NCG emissions tables (Table 10-1) reflect trends for emissions of these trace substances. Namely, improving brine utilization for a given technology at a given site reduces the relative amount of emissions. 
Table 10-1

Open Cycle NCG Emissions Tables

(Dual Flash Economic Optimum Cases)

\begin{tabular}{|c|c|c|c|c|c|c|c|c|c|}
\hline Site & $\begin{array}{c}\text { NCGs } \\
\text { ppm }\end{array}$ & $\begin{array}{c}\text { H2S } \\
\text { ppm }\end{array}$ & $\begin{array}{c}\text { Brine Flow } \\
\text { lb/hr }\end{array}$ & $\begin{array}{c}\text { Air Flow } \\
\text { lb/hr }\end{array}$ & $\begin{array}{c}\text { Net P } \\
\text { (kW })\end{array}$ & $\begin{array}{c}\text { CO2 } \\
\text { lb/hr }\end{array}$ & $\begin{array}{c}\text { CO2 } \\
\text { ppm }\end{array}$ & $\begin{array}{c}\text { H2S } \\
\text { lb/hr } / \mathrm{hr}\end{array}$ & $\begin{array}{c}\text { H2S } \\
\text { ppm }\end{array}$ \\
\hline Coso Hot Springs & 2000 & 105 & $3,200,000$ & $23,209,013$ & 51,995 & 61,221 & 824 & 11 & 0.46 \\
\hline Desert Peak & 290 & 4 & $4,500,000$ & $27,365,173$ & 47,946 & 1,342 & 11 & 11 & 0.42 \\
\hline Dixie Valley & 2000 & 5 & $4,000,000$ & $27,268,550$ & 47,902 & 8,330 & 76 & 11 & 0.42 \\
\hline Raft River & 2000 & 0.2 & $19,226,528$ & $46,416,825$ & 50,001 & 38,448 & 43 & 4 & 0.24 \\
\hline Glass Mountain & 1700 & 20 & $3,000,000$ & $26,437,423$ & 51,339 & 4,909 & 62 & 11 & 0.41 \\
\hline Salton Sea & 1360 & 16 & $2,600,000$ & $31,457,431$ & 47,833 & 3,653 & 45 & 11 & 0.37 \\
\hline Surprise Valley & 2000 & 20 & $7,473,481$ & $37,508,306$ & 49,998 & 14,798 & 53 & 11 & 0.29 \\
\hline Vale & 2000 & 20 & $12,450,000$ & $43,120,111$ & 50,000 & 24,651 & 46 & 11 & 0.26 \\
\hline
\end{tabular}

(Dual Flash - Binary I Economic Optimum Cases)

\begin{tabular}{|c|c|c|c|c|c|c|c|c|c|}
\hline Site & $\begin{array}{c}\text { NCGs } \\
\text { ppm }\end{array}$ & $\begin{array}{c}\text { H2S } \\
\text { ppm }\end{array}$ & $\begin{array}{c}\text { Brine Flow } \\
\mathrm{lb} / \mathrm{hr}\end{array}$ & $\begin{array}{c}\text { Air Flow } \\
\mathrm{lb} / \mathrm{hr}\end{array}$ & $\begin{array}{c}\text { Net P } \\
(\mathrm{kW})\end{array}$ & $\begin{array}{c}\mathrm{CO} 2 \\
\mathrm{lb} / \mathrm{hr}\end{array}$ & $\begin{array}{c}\mathrm{CO} 2 \\
\mathrm{ppm}\end{array}$ & $\begin{array}{c}\mathrm{H} 2 \mathrm{l} \\
\mathrm{lb} / \mathrm{hr}\end{array}$ & $\begin{array}{c}\mathrm{H} 2 \mathrm{~S} \\
\mathrm{ppm}\end{array}$ \\
\hline Desert Peak & 290 & $\mathbf{4}$ & $4,500,000$ & $24,417,960$ & 54,713 & 1,176 & 11 & 11 & 0.41 \\
\hline Raft River & 2000 & 0.2 & $12,593,278$ & $23,273,965$ & 48,872 & 25,765 & 88 & 3 & 0.48 \\
\hline Glass Mountain & 1700 & 20 & $2,700,000$ & $20,768,104$ & 52,470 & 4,322 & 77 & 11 & 0.50 \\
\hline Surprise Valley & 2000 & 20 & $6,794,074$ & $24,648,631$ & 53,434 & 12,588 & 75 & 11 & 0.42 \\
\hline Vale, Oregon & 2000 & 20 & $9,683,334$ & $19,506,450$ & 50,507 & 18,981 & 100 & 11 & 0.56 \\
\hline
\end{tabular}

(Dual Flash Gas Turbine Economic Optimum Cases)

\begin{tabular}{|c|c|c|c|c|c|c|c|c|c|}
\hline Site & $\begin{array}{c}\text { NCGs } \\
\text { ppm }\end{array}$ & $\begin{array}{c}\text { H2S } \\
\text { ppm }\end{array}$ & $\begin{array}{c}\text { Brine Flow } \\
\mathrm{lb} / \mathrm{hr}\end{array}$ & $\begin{array}{c}\text { Air Flow } \\
\mathrm{lb} / \mathrm{hr}\end{array}$ & $\begin{array}{c}\text { Net P } \\
(\mathrm{kW})\end{array}$ & $\begin{array}{c}\text { CO2 } \\
\mathrm{lb} / \mathrm{hr}\end{array}$ & $\begin{array}{c}\text { CO2 } \\
\mathrm{ppm}\end{array}$ & $\begin{array}{c}\mathrm{H} 2 \mathrm{l} \\
\mathrm{lb} / \mathrm{hr}\end{array}$ & $\begin{array}{c}\mathrm{H} 2 \mathrm{~S} \\
\mathrm{ppm}\end{array}$ \\
\hline Coso Hot Springs & 20000 & 105 & $1,600,000$ & $15,413,385$ & 49,146 & 32,385 & 1,313 & 11 & 0.73 \\
\hline Desert Peak & 290 & 4 & $2,500,000$ & $21,919,759$ & 52,222 & 685 & 12 & 10 & 0.48 \\
\hline Dixie Valley & 2000 & 5 & $2,000,000$ & $18,221,997$ & 49,640 & 4,019 & 110 & 10 & 0.61 \\
\hline Raft River & 2000 & 0.2 & $10,687,500$ & $25,414,206$ & 49,556 & 21,564 & 79 & 2 & 0.44 \\
\hline Glass Mountain & 1700 & 20 & $1,500,000$ & $16,529,000$ & 50,010 & 2,519 & 102 & 11 & 0.67 \\
\hline Salton Sea & 1360 & 16 & $1,300,000$ & $21,985,123$ & 51,397 & 1,700 & 59 & 11 & 0.49 \\
\hline Surprise Valley & 2000 & 20 & $4,066,000$ & $21,567,039$ & 49,863 & 8,073 & 92 & 11 & 0.51 \\
\hline Vale & 2000 & 20 & $6,982,713$ & $26,013,936$ & 50,986 & 13,558 & 75 & 11 & 0.41 \\
\hline
\end{tabular}


Table 10-1

\section{Open Cycle NCG Emissions Tables}

(Continued)

(Rotary Separator Turbine Economic Optimum Cases)

\begin{tabular}{|c|c|c|c|c|c|c|c|c|c|}
\hline Site & NCGs & H2S & Brine Flow & Air Flow & Net P & CO2 & CO2 & H2S & H2S \\
\hline & ppm & ppm & lb/hr & lb/hr & (kW) & lb/hr & ppm & lb/hr & ppm \\
\hline Coso Hot Springs & 20000 & 105 & $3,200,000$ & $24,719,952$ & 52,795 & 60,294 & 762 & 11 & 0.42 \\
\hline Desert Peak & 290 & 4 & $4,500,000$ & $26,185,083$ & 48,289 & 1,333 & 11 & 11 & 0.43 \\
\hline Dixie Valley & 2000 & 5 & $4,000,000$ & $25,499,100$ & 48,271 & 8,266 & 81 & 11 & 0.45 \\
\hline Glass Mountain & 1700 & 20 & $3,000,000$ & $25,185,190$ & 51,924 & 4,853 & 64 & 11 & 0.42 \\
\hline Salton Sea & 1360 & 16 & $2,600,000$ & $31,449,781$ & 50,970 & 3,428 & 42 & 11 & 0.34 \\
\hline
\end{tabular}

(Advanced Flash Economic Optimum Cases)

\begin{tabular}{|c|c|c|c|c|c|c|c|c|c|}
\hline Site & NCGs & H2S & Brine Flow & Air Flow & Net P & CO2 & CO2 & H2S & H2S \\
\hline & ppm & ppm & lb/hr & lb/hr & (kW) & lb/hr & Ppm & lb/hr & ppm \\
\hline Desert Peak & 290 & 4 & $4,500,000$ & $24,299,935$ & 47,560 & 1,353 & 12 & 11 & 0.48 \\
\hline Dixie Valley & 2000 & 5 & $4,000,000$ & $24,264,714$ & 47,521 & 8,396 & 87 & 11 & 0.48 \\
\hline Glass Mountain & 1700 & 20 & $3,000,000$ & $23,348,009$ & 51,347 & 4,908 & 70 & 11 & 0.46 \\
\hline Salton Sea & 1360 & 16 & $2,600,000$ & $29,425,682$ & 48,297 & 3,618 & 47 & 11 & 0.39 \\
\hline Surprise Valley & 2000 & 20 & $7,473,481$ & $36,715,550$ & 48,221 & 15,343 & 56 & 11 & 0.31 \\
\hline
\end{tabular}

(Subatmospheric Flash Economic Optimum Cases)

\begin{tabular}{|c|c|c|c|c|c|c|c|c|c|}
\hline Site & NCGs & H2S & Brine Flow & Air Flow & Net $P$ & $\mathrm{CO} 2$ & $\mathrm{CO} 2$ & $\mathrm{H} 2 \mathrm{~S}$ & $\mathrm{H} 2 \mathrm{~S}$ \\
\hline & ppm & ppm & $\mathrm{lb} / \mathrm{hr}$ & $\mathrm{lb} / \mathrm{hr}$ & $(\mathrm{kW})$ & $\mathrm{lb} / \mathrm{hr}$ & ppm & $\mathrm{lb} / \mathrm{hr}$ & ppm \\
\hline Raft River & 2000 & $\overline{0.2}$ & 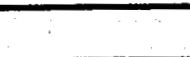 & & & $\overline{0}$ & & 0 & \\
\hline Surprise Valley & 2000 & 20 & & $i$ & & 0 & & 0 & \\
\hline Vale, Oregon & 2000 & 20 & & & & 0 & & 0 & \\
\hline Thermo Hot Sp & 2000 & 20 & & & & $\overline{0}$ & & $\overline{0}$ & \\
\hline
\end{tabular}


The Kalina cycle and all other varieties of binary plants are closed cycle plants. Closed cycle plants do not expose the geothermal fluid to the atmosphere and therefore do not do not emit noncondensable gases. Flash binary hybrid II, the back pressure turbine cycle, is also a closed cycle plant.

Although these closed cycle plants do not emit noncondensable gases, they do emit some of their working fluids through leakage. The Kalina cycle emits ammonia, which is a colorless gas that acts as a respiratory irritant. The other binary cycles emit mixtures of light hydrocarbons such as isobutane and isopentane, which are also colorless gases that act as respiratory irritants. Data from operating binary plants shows that they lose some working fluid circulation. In general, the colder resources use greater amounts of working fluid and therefore leak a greater quantity of working fluid.

Gas turbine hybrid plants burn light hydrocarbon fuel, which we assume is methane. The normal combustion products are $\mathrm{CO}_{2}$ and water. In addition to these products, a side reaction involving the nitrogen and oxygen in the air produces small amounts of nitrogen oxides, or $\mathrm{NO}_{\mathrm{x}}$. The gas turbine emissions tables (Table 10-2) show the emissions for the two types of gas turbine hybrid plants.

\section{Water Consumption}

Water cooled plants that do not use condensate as cooling water makeup, will require an outside water source. This can impact the surrounding domestic and natural water supply. In this study, only water cooled binary plants do not use condensate as make up.

\section{Aesthetics}

All of the technologies that are water cooled employ cooling towers. Cooling towers will have visible plumes of water vapor that vary in size depending upon the amount of water evaporated and on the humidity. Although these plumes are essentially clean distilled water vapor, to some they may appear unattractive. Depending on the location of the plant, this can be of concern. 
Table 10-2

Gas Turbine Exhaust

\begin{tabular}{|c|c|c|c|c|c|}
\hline \multirow[b]{2}{*}{ Site } & \multicolumn{5}{|c|}{ Dual Flash - Gas Turbine } \\
\hline & $\begin{array}{l}\text { Fuel } \\
\# / \mathrm{hr}\end{array}$ & $\begin{array}{l}\text { NOx } \\
\# / h r\end{array}$ & $\begin{array}{l}\text { NOx } \\
\text { ppm }\end{array}$ & $\begin{array}{l}\mathrm{CO} 2 \\
\# / \mathrm{hr}\end{array}$ & $\begin{array}{l}\mathrm{CO} 2 \\
\text { ppm }\end{array}$ \\
\hline Coso Hot Springs & 9,407 & 11.79 & 25 & 25,869 & 54,867 \\
\hline Desert Peak & 9,476 & 11.87 & 25 & 26,059 & 54,867 \\
\hline Dixie Valley & 9,879 & 12.38 & 25 & 27,167 & 54,867 \\
\hline Raft River & 9,566 & 11.99 & 25 & 26,307 & 54,867 \\
\hline Glass Mountain & 9,276 & 11.62 & 25 & 25,509 & 54,867 \\
\hline Salton Sea & 10,700 & 13.41 & 25 & 29,425 & 54,867 \\
\hline Surprise Valley & 9,476 & 11.87 & 25 & 26,059 & 54,867 \\
\hline Thermo Hot Sp & 9,068 & 11.36 & 25 & 24,937 & 54,867 \\
\hline Vale, Oregon & 9,625 & 12.06 & 25 & 26,469 & 54,867 \\
\hline
\end{tabular}

\begin{tabular}{|c|c|c|c|c|c|}
\hline \multirow[b]{2}{*}{ Site } & \multicolumn{5}{|c|}{ Binary - Gas Turbine } \\
\hline & $\begin{array}{l}\text { Fuel } \\
\# / \mathrm{hr}\end{array}$ & $\begin{array}{l}\text { NOx } \\
\# / h r\end{array}$ & $\begin{array}{l}\text { NOx } \\
\text { ppm }\end{array}$ & $\begin{array}{l}\mathrm{CO} 2 \\
\# / \mathrm{hr}\end{array}$ & $\begin{array}{l}\mathrm{CO} 2 \\
\mathrm{ppm}\end{array}$ \\
\hline Raft River & 9,564 & 11.98 & 25 & 26,301 & 54,867 \\
\hline Surprise Valley & 9,479 & 11.88 & 25 & 26,067 & 54,867 \\
\hline Thermo Hot Sp & 9,066 & 11.36 & 25 & 24,932 & 54,867 \\
\hline Vale Oregon & 9,625 & 12.06 & 25 & 26,469 & 54,867 \\
\hline
\end{tabular}




\section{Safety}

Conventional binary cycles use flammable working fluids at high pressures. They also receive regular shipments of working fluids to make up for leakage. These flammable components of the process pose a risk of explosion and fire not associated with other technologies that do not employ flammable working fluids.

Gas turbine hybrid plants burn natural gas at high pressures and at temperatures of over one thousand degrees Fahrenheit. They burn large quantities of gas that are on the order of ten thousand pounds per hour. These conditions also pose a fire risk not found in other geothermal technologies.

\section{Rankings}

Now that we have identified and discussed the environmental impacts that vary significantly from one technology to another, we may rank the technologies against each other. We rank the technologies from first on down based on a point system, and tabulate the rankings in Table 10-3.

A given technology receives a score from zero to eight, eight being best. A technology can earn one point in each of eight categories, if it does not have that particular negative environmental impact. Air emissions encompass five of the eight ranking categories. Water use, plume visibility, and fire risk are the other three.

In the event of a tie score, we give a higher ranking to the technology with better brine utilization. In many of the areas where environmental impact is not dependent upon the technology chosen, a plant that has better brine utilization would tend have a lesser environmental impact by virtue of its reduced scale. A smaller gathering system, for example, would tend to lessen impacts on land use, animal life, and so on. 
Table 10-3

Environmental Impact Rankings

\begin{tabular}{|c|c|c|c|c|c|c|c|c|c|}
\hline \multirow[b]{2}{*}{ Rank } & \multicolumn{5}{|c|}{$\begin{array}{c}1 \\
\text { Air } \\
\text { Emissions }\end{array}$} & \multirow{2}{*}{\begin{tabular}{|c|}
2 \\
Water \\
Fresh \\
mk-up
\end{tabular}} & \multirow{2}{*}{$\begin{array}{l}\text { 3 } \\
\text { Aesth } \\
\text { Visible } \\
\text { Plume }\end{array}$} & \multirow{2}{*}{\begin{tabular}{|c}
4 \\
Upset \\
Fire \\
Risk \\
\end{tabular}} & \multirow[b]{2}{*}{$\begin{array}{l}\text { Total } \\
\text { Score }\end{array}$} \\
\hline & $\begin{array}{l}\mathrm{NCG} \\
\mathrm{CO} 2\end{array}$ & $\begin{array}{l}\text { NCG } \\
\text { H2S }\end{array}$ & $\begin{array}{l}\text { Fuel } \\
\text { NOx }\end{array}$ & $\begin{array}{l}\text { Fuel } \\
\mathrm{CO} 2\end{array}$ & $\begin{array}{l}\text { Work } \\
\text { Fluid }\end{array}$ & & & & \\
\hline 1 Kalina & 1 & $\overline{1}$ & 1 & 1 & 0 & 1 & 1 & 0 & 6 \\
\hline 2 Binary (mixed fluids) & 1 & 1 & 1 & 1 & 0 & 1 & 1 & 0 & 6 \\
\hline 3 Binary (air cooled) & 1 & 1 & 1 & 1 & 0 & 1 & 1 & 0 & 6 \\
\hline 4 Dual Flash/Binary II & 1 & 1 & 1 & 1 & 0 & 1 & $\overline{1}$ & 0 & 6 \\
\hline 5 Rotary Sep Turbine & 0 & 0 & 1 & 1 & 1 & 1 & 0 & 1 & 5 \\
\hline 6 Sub Atm Flash & 0 & 0 & 1 & 1 & 1. & 1 & 0 & 1 & 5 \\
\hline 7 Advanced Flash & 0 & 0 & 1 & 1 & 1 & 1 & 0 & 1 & 5 \\
\hline 8 Dual Flash & 0 & 0 & 1 & 1 & 1 & 1 & 0 & 1 & 5 \\
\hline 9 Binary/Gas Turb & 1 & 1 & 0 & 0 & 0 & 1 & 1 & 0 & 4 \\
\hline 10 Binary (water cooled) & 1 & 1 & 1 & 1 & 0 & 0 & 0 & 0 & 4 \\
\hline 11 Dual Flash/Binary I & 0 & $\overline{0}$ & 1 & 1 & 0 & 1 & 0 & 0 & 3 \\
\hline 12 Dual Flash/Gas Turb & 0 & 0 & 0 & 0 & 1 & 1 & 0 & 0 & 2 \\
\hline
\end{tabular}




\section{1}

\section{NEXT GENERATION GEOTHERMAL POWER PLANT TECHNOLOGIES}

\section{Concept Ranking Methodology}

The goal of the next generation geothermal power plant study is to identify the best alternative for geothermal power generation at each of the sites. The most attractive technology at each of the sites will generally be the technology with the lowest cost of power generation. Therefore, levelized busbar cost is the primary criteria for ranking the technologies. Other factors affect the attractiveness of the various power generation technologies but their influence is harder to quantify. For technologies with levelized busbar cost within $5 \%$ of each other, the following secondary factors were considered in determining the relative ranking of the technologies:

\section{Technical Risk}

A technology with a long history of successful, commercial power plants presents a lower risk than a technology in the conceptual development stage. A concept that builds upon existing commercial geothermal technologies or components that are proven in geothermal service is less risky than one that does not. Table 11-5 lists the relative technical risk associated with each technology. All the baseline technologies are given a technical risk ranking of very low due to the large number of profitable power plants currently in operation. Mixed fluid binary cycle and a subatmospheric flash cycle are given a ranking of low risk even though they have not yet been installed in a commercial plant since there is little technical risk associated with their implementation. All the hybrid technologies build upon existing technologies, but are given a technical risk ranking of medium due to their added complexity. During recent testing of both the rotary separator turbine and a radial inflow turbine operating on a metastable binary cycle, damage to the turbine was observed. For this reason, both of these technologies, have been given a technology risk rating of medium/high. The Kalina cycle has been ranked as a high technical risk due to the large vertical heat exchangers and concerns regarding integral condensation in the air cooler. 


\section{Water Consumption}

Geothermal power plants must be located adjacent to the geothermal resource. In the western United States, few geothermal resources are located near an abundant surface water source. Therefore, plants that do not require an outside water source are preferred. The closed loop, binary and Kalina, plants are given a water consumption rating of none since the process consumes virtually no water. Water cooled flash plants are given a water consumption rating of low. Condensate is normally used as cooling tower make-up, but some plants may require additional water in dry summer weather. Since gas turbine auxiliaries may require some make up water, the gas turbine hybrid cycles were also given a ranking of low. Water cooled binary plants require an external cooling water supply, so this technology was given a water consumption ranking of high.

\section{Environmental Impact}

Technology with minimal environmental impact is preferred. A technology with a lower environmental impact will be easier to permit; thereby, reducing project costs. In addition, by being perceived as a good neighbor, the utility will generate goodwill in the community. Environmental impact ranking is summarized in Table 11-5. Environmental impact of each of the technologies was discussed in detail in Section 10.

\section{Levelized Busbar Cost Methodology}

Levelized busbar cost of power generation was calculated using the methodology explained in EPRI's 1993 Technical Assessment Guide (TAG) for levelized revenue requirement. 'The revenue requirement is defined as, "The total revenue that must be collected from customers to compensate a utility for all the expenditures associated with implementing a decision involving money." The levelized revenue requirement $\left(\mathrm{LRR}_{\mathrm{A}}\right)$ for the power plant was calculated using TAG Equation 6-27

$\mathrm{LRR}_{\mathrm{A}}=($ Investment $) \mathrm{Pm}, \mathrm{n}+\Sigma$ 'Expenses $) \mathrm{Ln}$

where,

Investment $=$ Total plant cost

Expenses $=$ All appropriate expenditures

Ln = Levelizing factor

$\mathrm{Pm}, \mathrm{n}=$ Levelized carrying charge of a plant item with an $\mathrm{m}$ year tax recovery class and $\mathrm{n}$ year book life

The following assumptions (given in TAG Table 6-3) were used by EPRI to calculate that $\mathrm{Pm}, \mathrm{n}$ is 0.141 
Table 11-1

Levelized Busbar Cost of Power Generation Assumptions

\begin{tabular}{|l|l|}
\hline Tax Recovery Period & 5 years \\
\hline Book Life & 30 years \\
\hline Discount Rate & $9.2 \% /$ year (after tax) \\
\hline Inflation Rate & $4.1 \% /$ year \\
\hline Federal and State Income Tax & $38 \%$ \\
\hline Property Tax and Insurance & $2 \%$ \\
\hline
\end{tabular}

Table 11 - 2 summarizes the additional assumptions that were used in calculating the levelized cost of the power plant. A capacity factor of $96 \%$ was used for all technologies. Existing binary and dual flash plants operate with capacities in excess of $96 \%$. Emerging technologies will need to achieve technologies of $96 \%$ if they are to be commercial. Assumptions employed in calculating the capital cost of a $50 \mathrm{MW}$ geothermal plant were detailed in Section 4. Owner's costs include an allowance of $\$ 32 / \mathrm{kW}$ for siting and licensing, $\$ 100 / \mathrm{kW}$ for financing, and $\$ 100 / \mathrm{kW}$ for project costs. Annual operating and maintenance costs were assumed to be $\$ 95 / \mathrm{kW}$ for all concepts. This value is based on Holt's estimate of operating costs at existing binary and dual flash plants. It includes operating labor for both the plant and the wellfield, maintenance, equipment and materials, spares, office supplies and equipment, plant vehicles, building and ground maintenance, utilities and plant management. It also includes some allowance for overhead and contingency. 
Next Generation Geothermal Power Plant Technologies

Table 11-2

Levelized Busbar Cost of Power Plant Assumptions

\begin{tabular}{|l|l|}
\hline Capacity Factor & $96 \%$ \\
\hline O\&M Costs & $\$ 95 / \mathrm{kW} /$ year \\
\hline Owner's Costs & $\$ 232 / \mathrm{kW}$ \\
\hline Investment Tax Credit & $10 \%$ \\
\hline Royalty & $10 \%$ of revenue requirement \\
\hline Natural Gas & $\$ 4.36 / \mathrm{MMBtu}$ (EPRI's prediction) \\
& $\$ 1.73 / \mathrm{MMBtu}($ Current price $12 / 1 / 94)$ \\
\hline
\end{tabular}

Although chemical usage does not have a significant impact on the levelized busbar cost, it was identified as a separate line item since different plant cycles will have different chemical usage. For binary and Kalina cycles, a chemical cost of $\$ 60,000 /$ year was included for working fluid makeup and miscellaneous chemical usage. For water cooled plants, $\$ 80,000 /$ year was added for cooling water treatment. Actual water treatment costs will vary with site conditions and with the composition of the water used for cooling tower makeup. A cost of $\$ 147 /$ long ton of sulfur was included for the chemicals used in the liquid redox hydrogen sulfide abatement system. For all power generation concepts, $\$ 0.284 / \mathrm{lb}$ brine was added for $\mathrm{pH}$ modification of the hypersaline Salton Sea brine. This cost was based on the information that $100-120 \mathrm{ppm}$ of $\mathrm{HCl}$ is added at the Salton Sea. (Hoyer, 1991)

Since geothermal field operation and development are riskier than development of a power plant and because the field will probably be owned and operated by a private developer, a discount rate of $20 \%$ was used to levelize the cost of the well field instead of the EPRI recommended $9.2 \%$. In addition to the production wells, injection wells, and the gathering system, the resource development costs listed in Table 11-3 were also included in the wellfield capital cost. A result of using a higher discount rate for the wellfield than for the plant is that a cycle with somewhat higher capital cost but better specific output may have a lower levelized cost of power generation than a less efficient, lower capital cost cycle. 
Table 11-3

Resource Development Costs

\begin{tabular}{|l|l|c|}
\hline & & $\begin{array}{c}\text { Thousand } \\
\text { Dollars }\end{array}$ \\
\hline $\begin{array}{l}\text { Soft Cost/ } \\
\text { Investment }\end{array}$ & Geologic Mapping & \\
\hline & Geochemistry & 90 \\
\hline & Gravimetry & 95 \\
\hline & Geoelectrical Survey & 90 \\
\hline & Temp. Gradient Drilling & 335 \\
\hline $\begin{array}{l}\text { Exploratory } \\
\text { Investment }\end{array}$ & Modeling & 65 \\
\hline & & \\
\hline & Primary Test Well & 2500 \\
\hline $\begin{array}{l}\text { Field Rework } \\
\text { and } \\
\text { Maintenance }\end{array}$ & Secondary Test Well & 1875 \\
\hline & & \\
\hline
\end{tabular}

\section{Levelized Busbar Cost Results}

Table 11- 4 lists the levelized revenue requirement for power generation for each of the technologies at each of the sites. Trends visible in this table have been discussed throughout this report. The cost of power generation usually increases with decreasing resource temperature. For the hotter self flowing wells, some reservoir specific characteristics can cause cost to be above or below this trend. For example, plants at $\operatorname{Coso}\left(525^{\circ} \mathrm{F}\right)$ have a slightly higher cost than Glass Mountain $\left(510^{\circ} \mathrm{F}\right)$ due to the higher noncondensable gas content of the steam at Coso. Also, power generation at Dixie Valley $\left(450^{\circ} \mathrm{F}\right)$ is less expensive than at Glass Mountain due to the higher well productivity at Dixie Valley. Brine flow and other plant characteristics are similar for all four of the cooler sites, so cost variations are less. 
For the baseline technologies, dual flash plants are preferred for higher temperature resources and binary plants for lower temperature resources. The transition from dual flash to binary would be at some temperature between $375^{\circ} \mathrm{F}$ to $425^{\circ} \mathrm{F}$. Cost of onsite plant equipment for a flash plant is significantly less expensive than for a binary type plant. With a higher temperature resource, well costs are a lower percentage of the total cost, so a simpler, less efficient plant is preferred. With colder resources, well costs increase dramatically, so a more expensive, more efficient plant is needed. 
Table 11-4

Levelized Revenue Requirement

\begin{tabular}{|c|c|c|c|c|c|c|c|c|c|}
\hline Resource & \begin{tabular}{r|} 
Salton \\
Sea
\end{tabular} & Coso & $\begin{array}{l}\text { Glass } \\
\text { Mtn. }\end{array}$ & \begin{tabular}{|r|} 
Dixie \\
Valley
\end{tabular} & $\begin{array}{r}\text { Desert } \\
\text { Peak }\end{array}$ & $\begin{array}{r}\text { Surprise } \\
\text { Valley }\end{array}$ & Vale & $\begin{array}{r}\text { Raft } \\
\text { River }\end{array}$ & Thermo \\
\hline Resource Temp., ${ }^{2} F$ & 570 & 525 & $\overline{510}$ & 450 & 425 & 375 & 330 & 300 & 265 \\
\hline \multicolumn{10}{|l|}{ Baseline Technologies } \\
\hline Com'l Binary & & & $\overline{7.55}$ & & & 7.10 & 7.69 & 9.41 & 12.70 \\
\hline Water-cooled Binary & & & & 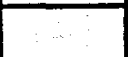 & & 7.08 & 7.64 & 9.32 & 13.15 \\
\hline Com'l Dual Flash & 4.83 & 6.16 & 6.36 & 5.21 & 6.32 & 7.78 & 8.95 & 10.84 & \\
\hline \multicolumn{10}{|l|}{ Advanced Binary Cycles } \\
\hline Mixed Fluids & & & 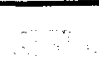 & 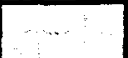 & & 6.79 & 7.64 & 9.25 & 12.58 \\
\hline Binary-Syn. Turbine & & & 6.86 & & & 6.62 & 7.67 & 9.14 & 12.04 \\
\hline Mixed Fluids - Syn. Turbine & & & & & & 6.65 & 7.37 & 8.93 & 12.02 \\
\hline Metastable Expansion & & & & & & 7.29 & 8.04 & 9.38 & \\
\hline \multicolumn{10}{|l|}{ Advanced Flash } \\
\hline RST & 4.74 & 6.23 & 6.36 & 5.21 & 6.34 & $\ldots$ & & & \\
\hline Adv Flash, Reheater & 4.83 & & 6.37 & 5.26 & 6.38 & 8.03 & & & \\
\hline Sub-Atm Flash & & & & & & 7.74 & 8.90 & 10.63 & \\
\hline Kalina & 5.58 & & 6.96 & 5.67 & 6.40 & 6.63 & 7.76 & 8.46 & 11.24 \\
\hline \multicolumn{10}{|l|}{ Geothermal Hybrid Cycles } \\
\hline DF/ Bin. Bottoming & & & 6.49 & & 6.18 & 7.30 & 8.66 & 9.91 & \\
\hline \multicolumn{10}{|l|}{ GT High Fuel Cost } \\
\hline GT/ Binary Hybrid & $\ldots$ & & $\ldots$ & $2 \ldots$ & $\ldots$ & 8.35 & 8.82 & 9.49 & 11.49 \\
\hline GT/ Dual Flash Hybrid & 7.33 & 8.30 & 8.23 & 7.61 & 7.88 & 8.77 & 9.55 & 10.83 & 15.73 \\
\hline \multicolumn{10}{|l|}{ GT Hybrid (High Fuel Cost) } \\
\hline GT/ Binary Hybrid & & & & & & 6.64 & 7.08 & $\overline{7.77}$ & 9.85 \\
\hline GT/ Dual Flash Hybrid & 5.69 & 6.59 & 6.55 & 5.84 & 6.25 & 7.06 & 7.85 & $\overline{9.10}$ & 13.97 \\
\hline \multicolumn{10}{|l|}{ GT Average Fuel Cost } \\
\hline GT/ Binary Hybrid & & & & & & 7.50 & 7.95 & 8.63 & 10.67 \\
\hline GT/ Dual Flash Hybrid & 6.51 & 7.44 & 7.39 & 6.72 & 7.06 & 7.91 & 8.70 & 9.97 & 14.85 \\
\hline
\end{tabular}


Table 11-5

Secondary Ranking Criteria

Technology
\begin{tabular}{|c|c|c|c|}
\hline Baseline Technologies & Risk & Consumption & Impact \\
\hline Baseline Binary & & & \\
\hline Water-cooled Binary & Very Low & None & Very Low \\
\hline Baseline Dual Flash & Very Low & High & Low \\
\hline Advanced Binary & Very Low & Low & Low \\
\hline Mixed Fluids & & & \\
\hline Binary-Syn. Turbine & Low & None & Very Low \\
\hline Mixed Fluids - Syn. Turbine & Low/Medium & None & Very Low \\
\hline Metastable Expansion & Medium & None & Very Low \\
\hline Advanced Flash & Medium/High & None & Very Low \\
\hline RST & & & \\
\hline Adv Flash, Reheater & Medium/High & Low & Low \\
\hline Sub-Atm Flash & Medium & Low & Low \\
\hline Kalina & Low & None & Low \\
\hline Hybrid Cycles & High & None & Very Low \\
\hline DF/ Bin. Bottoming & Medium & Low & Low \\
\hline GT/ Binary Hybrid & Low & Medium \\
\hline GT/ Dual Flash Hybrid & Low & Medium \\
\hline
\end{tabular}




\section{Concept Ranking Results}

Table 11-6 gives the relative ranking for each of the technologies at each of the sites. A discussion of the results follows.

\section{Salton Sea}

The levelized revenue requirement for power generation using a baseline dual flash plant at Salton Sea is $4.83 \mathrm{c} / \mathrm{kWh}$. The flash reheater concept is a variation on dual flash. Since the cost of power with a flash reheater is identical to that of dual flash, there is no incentive to install a more complex, higher risk plant. Therefore, it is rated lower. A dual flash plant with a Rotary Separator Turbine installed on the wellhead geothermal fluid has a slightly lower busbar cost.

In this study, turbine inlet temperature was limited to $360^{\circ} \mathrm{F}$ due to metallurgical concerns. The optimum high pressure flash temperature for a dual flash plant operating at Salton Sea is higher than $360^{\circ} \mathrm{F}$. As a result, RST is able to generate $7 \%$ more power than a conventional dual flash plant.

Salton Sea is a hypersaline, highly corrosive resource. Brine handling is a special concern for any plant installed on this resource. In this study, chemical cost for $\mathrm{pH}$ control of about 0.3 cents $/ \mathrm{kWh}$ was added for all technologies. Excessive scaling or material compatibility may be a concern with RST operating on this resource.

DOE is currently sponsoring a demonstration of RST at Coso Geothermal Power Plant. Since the rotary separator turbine is considered a medium to high technical risk and the difference in busbar cost between RST and dual flash is less than 5\%, baseline dual flash is the preferred technology at Salton Sea.

\section{Coso}

Conventional dual flash is the most cost effective cycle for power generation at Coso. Due to the higher noncondensable gas content at Coso, some of the dual flash alternatives, such as Kalina cycle 13, were not appropriate. One of the assumptions of this study was that the wellhead pressures and flows were the same for all the wells at a given site. Consequently, the RST technology did not offer a significant advantage for the power plant as a whole. Currently, however, a DOE sponsored test of RST is occurring at Coso on one well that has a significantly higher pressure than other wells feeding the high pressure steam manifold. For resources in which there is significant variation in wellhead pressures, the RST technology may offer a way to increase the overall performance of a steam flash power plant by recovering energy that would otherwise be lost in throttling the steam to the lowest common pressure. 
Table 11-6

Concept Ranking

\begin{tabular}{|c|c|c|c|c|c|c|c|c|c|}
\hline Resource & \begin{tabular}{|c|} 
Salton \\
Sea
\end{tabular} & Coso & $\begin{array}{l}\text { Glass } \\
\text { Mtr. } \\
\end{array}$ & $\begin{array}{c}\text { Dixie } \\
\text { Valley }\end{array}$ & \begin{tabular}{|c|} 
Desert \\
Peak
\end{tabular} & \begin{tabular}{|l|} 
Surprise \\
Valley
\end{tabular} & \begin{tabular}{|l|} 
Vale \\
\end{tabular} & $\begin{array}{l}\text { Raft } \\
\text { River }\end{array}$ & Thermo \\
\hline Resource Temp. ${ }^{\circ} \mathrm{F}$ & 570 & 525 & 510 & 450 & 425 & 375 & 330 & 300 & 265 \\
\hline \multicolumn{10}{|l|}{ Baseline Technologies } \\
\hline Air-cooled Binary & N/A & N/A & 7 & $\mathrm{~N} / \mathrm{A}$ & $\mathrm{N} / \mathrm{A}$ & 5 & 1 & 6 & 6 \\
\hline $\begin{array}{l}\text { Water-cooled } \\
\text { Binary }\end{array}$ & N/A & N/A & N/A & N/A & $\mathrm{N} / \mathrm{A}$ & $\overline{6}$ & 3 & 7 & 7 \\
\hline Dual Flash & 1 & 1 & 1 & 1 & 1 & 11 & 9 & 10 & N/A \\
\hline \multicolumn{10}{|l|}{$\begin{array}{l}\text { Advanced Binary } \\
\text { Cycles }\end{array}$} \\
\hline Mixed Fluids & N/A & N/A & N/A & $\overline{\mathrm{N} / \mathrm{A}}$ & $\overline{N / A}$ & 1 & 2 & 3 & 3 \\
\hline $\begin{array}{l}\text { Binary-Synch. } \\
\text { Turbine }\end{array}$ & $\mathrm{N} / \mathrm{A}$ & N/A & 5 & N/A & $\mathrm{N} / \mathrm{A}$ & 2 & 4 & $\overline{4}$ & 4 \\
\hline $\begin{array}{l}\text { Mixed Fluids } \\
\text {-Synch. Turbine }\end{array}$ & N/A & N/A & N/A & $\mathrm{N} / \mathrm{A}$ & N/A & 3 & 5 & 5 & 5 \\
\hline $\begin{array}{l}\text { Metastable } \\
\text { Expansion }\end{array}$ & $\mathrm{N} / \mathrm{A}$ & N/A & N/A & $\mathrm{N} / \mathrm{A}$ & $\mathrm{N} / \mathrm{A}$ & 8 & 8 & 9 & $\mathrm{~N} / \mathrm{A}$ \\
\hline \multicolumn{10}{|l|}{ Advanced Flash } \\
\hline RST & 2 & 2 & 2 & 2 & 3 & N/A & $\mathrm{N} / \mathrm{A}$ & $\mathrm{N} / \mathrm{A}$ & $\mathrm{N} / \mathrm{A}$ \\
\hline $\begin{array}{l}\text { Adv Flash, } \\
\text { Reheater }\end{array}$ & 3 & $\mathrm{~N} / \mathrm{A}$ & 3 & 3 & 4 & 11 & N/A & $\mathrm{N} / \mathrm{A}$ & $\mathrm{N} / \mathrm{A}$ \\
\hline Sub-Atm Flash & $\mathrm{N} / \mathrm{A}$ & N/A & $\mathrm{N} / \mathrm{A}$ & N/A & N/A & 9 & 10 & 12 & N/A \\
\hline Kalina & 4 & N/A & 6 & $\overline{4}$ & 5 & $\overline{4}$ & $\overline{6}$ & 1 & 2 \\
\hline \multicolumn{10}{|l|}{ Hybrid Cycles } \\
\hline DF/ Bin. Bottoming & N/A & N/A & $\overline{4}$ & $\bar{N} / A$ & 2 & 7 & 9 & 8 & $\mathrm{~N} / \mathrm{A}$ \\
\hline GT/ Binary Hybrid & $\mathbf{N} / \mathrm{A}$ & N/A & N/A & N/A & $\mathrm{N} / \mathrm{A}$ & 10 & 7 & 2 & 1 \\
\hline $\begin{array}{l}\text { GT/ Dual Flash } \\
\text { Hybrid }\end{array}$ & 5 & 3 & 8 & 5 & 6 & 12 & 11 & 11 & 8 \\
\hline
\end{tabular}


At a resource with higher noncondensable gas content and higher $\mathrm{H}_{2} \mathrm{~S}$ content in the steam, the next generation geothermal technology is not likely to be a novel cycle. Rather, development should focus on more efficient gas removal systems and more cost effective sulfur handling systems.

\section{Glass Mountain and Dixie Valley}

For both Glass Mountain and Dixie Valley, a standard dual flash cycle is the low cost alternative. Since the advanced concepts are not more economical, there is no incentive to pursue these higher risk options.

\section{Desert Peak}

A dual flash/ binary bottoming cycle is the most economical alternative at Desert Peak. This resource has the lowest temperature of the free-flowing resources but a relatively low flow from each well. This makes well and gathering system costs relatively more expensive. As a result; it is important to achieve a higher thermal efficiency than is possible in a straight dual flash cycle.

This study assumes that all plants produce a nominal $50 \mathrm{MW}$ net. Since hybrid plants are essentially two smaller plants with some heat transfer between the two plants, economies of scale tend to make the hybrid plants more expensive than non-hybrid plant. Even so, dual flash/ binary is the most cost effective option at Desert Peak.

Dual flash/ binary bottoming cycle is a relatively low risk advanced technology. The dual flash component is identical to a standard dual flash plant. Similarly, the binary portion is a standard air-cooled binary plant. The heat exchanger that couples the plants is identical in design to the brine/ hydrocarbon exchanger in a binary plant. In the design of this plant some attention must be paid to the scaling properties of brine at lower temperatures.

However, since the dual flash/ binary bottoming cycle is a higher risk option than the baseline dual flash and the levelized busbar cost is only $2.25 \%$ lower, the baseline dual flash was given the higher ranking.

\section{Surprise Valley}

At Surprise Valley, the levelized revenue requirement for power generation is nearly identical for all of the advanced binary concepts as well as KCS 11. Although the lowest cost alternative is a standard binary cycle with a synchronous, high efficiency turbine, this technology is ranked as a medium to high technical risk since a turbine of this size and type has not operated 
commercially. A mixed fluid cycle plant at Surprise Valley would consist of major equipment identical to the equipment used in commercial binary plants but the working fluid would be $96 \%$ isobutane and $6 \%$ heptane instead of $100 \%$ commercial isobutane. Since this is the lowest risk technology in this group of concepts with nearly the same cost, a mixed fluid cycle is ranked as the preferred technology at Surprise Valley.

$\underline{\text { Vale }}$

At Vale, a standard binary cycle is more cost effective than the more complex Kalina cycle. The use of a working fluid that consists of $94 \%$ isobutane $6 \%$ heptane instead of commercial isobutane decreases the cost of power generation by $1 \%$ and using the advanced turbine proposed by Barber-Nichols decreases the cost another $4.5 \%$. Since none of the advanced binary concepts, decrease the cost of power generation by more than $5 \%$, air cooled binary is the highest ranked technology for the $330^{\circ} \mathrm{F}$ resource at Vale.

\section{Raft River and Thermo Hot Springs}

Power generation from these cold resources requires an efficient conversion technology to be cost effective. Kalina Cycle 11 is a lower cost alternative than standard binary cycles operating on hydrocarbons. In this study, KCS 11 has been ranked as a high technical risk due to the large vertical heat exchangers and concerns regarding integral condensation in the air cooler. The technical risks associated with the Kalina cycle were discussed in detail in Section 8. A 12 MW KCS 11 demonstration plant at the Steamboat Springs, Nevada geothermal site is currently being sponsored by DOE. Results of this demonstration plant will answer questions on constructability and performance of KCS 11.

A gas turbine/ binary hybrid is another alternative for the low temperature sites. Technical risk associated with this hybrid is relatively low. The performance and reliability of standard commercial gas turbines are well documented and binary geothermal plants are also a proven technology. The exhaust gas heat exchanger which couples the fossil fuel and geothermal cycles is similar to waste heat recovery units in cogeneration facilities.

The primary risk associated with the gas turbine hybrid option is natural gas price. Using EPRI's number for natural gas of \$4.36, the hybrid is not the low cost alternative. Using today's price of $\$ 1.73$, a natural gas hybrid is the most cost effective generation method at both Raft River and Thermo Hot Springs. In recent years, predictions of fuel price increases have usually been high. For assigning the ranking, busbar cost based on the average of the higher and lower fuel prices was used. 
A gas turbine hybrid would have significantly higher emission than other geothermal concepts. Although natural gas is the cleanest fossil fuel, emissions from a gas turbine hybrid are still significantly higher than with an all geothermal plant. (See Section 10).

At Raft River, the cost of power generation with a Kalina cycle is $2 \%$ lower than with a natural gas hybrid. Although KCS 11 may be a somewhat riskier technology, this is offset by the risk of higher fuel prices. For this reason, Kalina cycle is ranked as the preferred technology at Raft River.

At Thermo Hot Springs, the cost of power generation with a gas turbine/binary hybrid assuming an average fuel price is more than $5 \%$ lower than the cost of power generated with a Kalina cycle plant. Therefore, a gas turbine/binary hybrid is the number one ranked technology at the coldest geothermal resource. 


\section{2}

\section{REFERENCES}

Baumann, K., "Some Recent Developments in Large Steam Turbine Practice", J. Inst. Elec. Eng., Vol. 59, 1921, p. 581.

Bleim and Mines, "Condensation Behavior of Supersaturated Turbine Expansions", 1992.

Bleim, Carl, Private Communication to John Mortz, "Power Production Using Mixed Fluids in Binary Units", 1994.

Bleim, Carl, Private Communication to John Mortz, "Reconciliation of differences in Power Production Using Mixed Fluids and Commercial Isobutane", 1994.

Bleim, Carl, "Supercritical Cycle Investigations", 1992.

Bleim, CJ and Mines, GL, "Advanced Binary Geothermal Cycles the Final Report on the Heat Cycle Research Program of the U.S. Department of Energy" (draft copy), 1993.

Cerini, D. J. and Hays, L. G., "Power Production From Geothermal Brine With the Rotary Separator", presented at the 15th IECEC in Seattle, Washington, (18-22 August 1980).

Cerini, "Demonstration of a Rotary Separator for Two-Phase Brine and Steam Flows", U. S. DOE, TID-28519. January 1978.

Demuth and Ko, "Analysis of Mixed Hydrocarbon Binary Thermodynamic Cycles for Moderate Temperature Geothermal Resources Using Regeneration Techniques", 1981.

Demuth, "Analysis of Mixed Hydrocarbon Binary Cycles for Moderate Temperature Geothermal Resources", 1982.

DiPippo, R. and Vrane, D.R., "A Double-Flash Plant with Interstage Reheat", GRC Trans., Vol. 15, 1991, pp. 381-386. 
Duchene, D., et al, "Hot Dry Rock Geothermal Energy Development Program", Annual Report, 1993 (Draft)

Duchene, D., Private Communication to John Mortz, 1994.

EPRI, Proceedings of the Third Annual Geothermal Conference and Workshop, EPRI WS-79-166, 1979.

Gogh, Frank van, Private Communication to Walker, Michael, "Wet Zone Operation", 1994.

Hinrichs, Frank, Geothermal Resource Council, Trans. p. 41 (May 1977).

Heber Test Data Report, (HEX Performance), 1993.

Holt, Ben, "Proceedings of the Third Annual Goethermal Conference and Workshop", EPRI WS-79-166, 1979.

Holt, B., Sims, A.V. and Campbell, R.G., "Proceedings of the Fifth Annual Goethermal Conference and Workshop", EPRI AP-2098, 1981.

Kalina, A.I. and Leibowitz, H.M., Geothermal Resource Council, Trans., 13, 1989.

Leibowitz, H.M., and Markus, D.W., Geothermal Resource Council, Trans, 14, 1990.

Li, K.W. and Priddy, A.P., Power Plant System Design, J. Wiley \& Sons, 1985. Milora, S.L. and Tester, J.W.."Geothermal Energy as a Source of Electric Power," MIT Press, 1976.

Mines and Bleim, "Improving the Efficiency of Binary Cycles", 1992.

Mines, G., "Geothermal Program Review XII", U.S. DOE, 1994.

Mines, Greg, Private Communication to Mai Hattar, "Preliminary Results from Radial-Inflow Reaction Turbine Test", 1994.

Mines, Greg. Private Communication to John Mortz, "Supersaturated Expansion", 1994.

Mortz, John, Private Communication to Carl Bleim, "Power Production from Binary Units Using Mixed Fluids", 1994.

Mortz, John, Private Communication to Carl Bleim, "Reconciliation of Power Production Inconsistencies, 1994. 
Purohit, G.P., "Estimating Costs of Shell and Tube Heat Exchangers", 1983.

Tiemat, et al., Condensation Film Coefficients for Mixtures of Isobutane and Isopentane", 1980. 


\section{APPENDIX A}

\section{Appendix A}

The following materials in Appendix $\mathrm{A}$ are a general discussion of process calculations used for analyzing various NGGPP concepts.

\section{Gathering System Spreadsheet}

The size and cost of a well head gathering system depends very much on the site location and the topography. For example it depends on whether the wells are located uphill or downhill from the plant, and on how far away the wells are from the plant. These are detailed engineering considerations and for the purposes of this study, an algorithm was employed to come up with a gathering system cost that would keep all sites on the same basis. This algorithm requires that wells be laid out in a hexagonal pattern, and then collected in a straight line. Up to 4 or 5 tiers were allowed in this configuration, and a fixed separation of 600 feet was used between wells and a distance of 750 feet was used between nodes.

Individual lines are sized based on velocity, and pressure drop in each branch is calculated. This yields the total pressure drop for the collection system. Calculations are stopped when the total pressure drop in the collection system is acceptable, and an associated cost based on the line size and length is calculated. This cost is the estimated cost of the gathering system. The magnitude of this cost does not affect the levelized cost of power production significantly since it represents only $1-2 \%$ of the total facility cost.

\section{Well Pump Spreadsheet}

Well pumps are different from standard pumps in that most of the horsepower requirement is for lifting the brine out of the well while still maintaining sufficient pressure on the fluid to suppress vaporization. Holt has developed a well pumping model based primarily on well depth, pump setting distance, well drawdown, and required pressure at the surface. The number of stages, the stage efficiency, and the motor efficiency is used to determine the size of the pump and the brake horsepower necessary. 


\section{Parasitics}

Air cooler fan horsepower is a significant parasitic load for the plant. It depends on how much air is required to perform the condensation of the working fluid. Holt's estimate of fin-fan horsepower is based on the actual air condensers purchased for commercial binary facilities. It is correlated on temperature rise and total condenser duty.

Well Pumping Parasitics are based on the Holt well pump model described above. On a case by case basis, the motor horsepower required is input into the cost model. The cumulative parasitics are calculated by summing the number of wells required in order to estimate this parasitic load.

Working fluid pumping is another significant parasitic load. It is calculated based on standard pump equations using the circulation rate of hydrocarbon, its density, the pressure losses in the Brine/Hydrocarbon heat exchange train, and the pressure required at the turbine inlet.

Miscellaneous parasitic losses are taken to be approximately $2 \%$ of gross power production. They include transformer losses, transmission losses, and other in-plant electrical requirements not included anywhere else.

\section{Heat Exchanger Calculations}

Heat exchanger sizing and cost is determined by calculating the surface area required and estimating the cost by using the cost per square foot of actual exchangers sold to Holt for other binary plant projects. The surface area is calculated using standard heat transfer methods, but adjustments are made to the cost for pressure, overall $U$, and fouling.

The pressure adjustments are made to the shell side costs to compensate for high pressure turbine inlets above 250 psia.. The method used was published in the August 22, 1983 issue of Chemical Engineering magazine. Estimating Costs Of Shell-And-Tube Heat Exchangers by G.P. Purohit.

The overall $U$ was determined for both the liquid preheating section and for the vaporization section of the binary unit. Since there is no vaporization section for supercritical cycles the $U$ was determined for the liquid portion below the pinch and the fluid portion above the pinch. Actual plant data were taken and subsequently verified by computer simulation.

Adjustment for brine fouling was made for each cycle based on a standard Holt correlation. The Overall $U$ for each heat exchanger section was derated according to the average brine temperature passing through each individual shell in the train. 


\section{APPENDIX B}

\section{Introduction}

The overall goal of this portion of the NGGPP study is to investigate turbine-generator subsystems that are reliable, efficient, and low cost. To achieve reliable operation, turbines that function at generator (synchronous) speeds with smail rotor diameters will be studied. This keeps the turbine operating stresses to a minimum. Such a design eliminates the requirement for a speed reducing gearbox, thereby reducing cost and improving reliability.

Efficient operation will be achieved by selecting the near optimum number of paralled units and the near optimum number of turbine stages. By careful selection of these items, each stage will be operating very near the conditions required for peak efficiency.

The goal of low cost will be achieved as follows: the gearbox is eliminated, the turbine design allows the use of low strength materials due to the low operating stress, and a common design can be used for various sites through minor modifications and by adding or deleting stages.

Therefore, the goals are quite clear as is the means of achieving them. However, the path to be followed is to use five sites with two different working fluids (commercial isobutane and a 94-6 isobutane-heptane mixture) as the models for the turbine design. Assuming a trade-off between two different numbers of parallel units and an average of approximately four stages per unit, there are approximately 160 different turbine wheel designs that should be calculated and studied to come up with the common set of hardware which will have up to five or six stages. With the limited budget of this program, the final result will be a reasonable first curt towards the ultimate, optimized design.

\section{Technical Background}

\section{Specific Speed and Specific Diameter.}

Given, for each site and working fluid, the working fluid flow rate and the head drop (enthalpy change) available to the turbine, the task at hand is to select the number of turbines in parallel, the number of turbine stages per turbine, and the diameter/blade length per stage to achieve good efficiency along with relatively small wheel diameters. The turbine shaft speed is to be the same as that of the generator (no gearbox). For the machine sizes (power output) under consideration generator shaft speeds of 3,600 rpm are available (2-pole generators) and will be the only shaft speed considered for this study.

To bring together these various parameters and correlate them with turbine performance and size, it is expedient to utilize some similarity parameters. The particular parameters to be utilized are the specific speed and specific diameter. These, in turn, are correlated with turbine performance (efficiency) through widely available charts. Just how these parameters are used is described below. 
Through the technique known as dimensional analysis, the similarity parameters specific speed, Ns, specific diameter, Ds, Reynolds number, Re, and Mach number, Ma, are derived and serve as convenient parameters for presenting the performance of turbomachines. These four parameters are sufficient to completely describe the performance of geometrically similar turbomachines. For a given volume flow rate and for a given head change through a turbomachine, specific speed is a number indicative of the rotational speed and specific diameter is a number indicative of the rotor diameter or the size of the machine. Reynolds number expresses the ratio of inertia force to viscous force and reflects the properties of the fluid flowing through the machine. Since turbines normally operate with compressible fluids, Mach number is used as the fourth similarity parameter.

It is difficult to present the performance of any turbine as a function of four parameters at one time. Fortunately, two of these variables, namely Reynolds number and Mach number, have only a secondary effect on turbine performance. More significantly, if the Reynolds mumber is above $10^{6}$ for turbines, the effect of Reynolds number is very nearly constant which eliminates it as a variable. Likewise, if the Mach number of the turbine is less than or near 0.5 , the compressibility effects are negligible which eliminates it as a variable. Turbine performance can then be presented as a function of the two variables, specific speed, Ns, and specific diameter, Ds. Therefore, this is the approach taken to analyze the performance of the multi-stage turbines for commercial isobutane and for the 94-6 mixture.

To better understand the basis of presenting turbine performance as a function of similarity parameters, an example and discussion of a performance plot for turbines will be covered below. The correlating similarity parameters, as discussed previously, are the specific speed Ns and specific diameter Ds

\begin{tabular}{|c|c|c|c|c|c|}
\hline \multirow{2}{*}{\multicolumn{2}{|c|}{ where }} & \multirow[t]{2}{*}{ Ns } & $=$ & \multicolumn{2}{|l|}{$\mathrm{NO}^{1 / 2}$} \\
\hline & & & ' & $\mathrm{H}^{3 / 4}$ & \\
\hline \multirow[t]{2}{*}{ and } & & & Ds & $=$ & $\underline{\mathrm{DH}^{1 / 4}}$ \\
\hline & & & & & $Q^{1 / 2}$ \\
\hline $\mathbf{N}$ & $=$ & \multicolumn{4}{|c|}{ rotational speed, $\mathrm{rpm}$} \\
\hline Q & $=$ & \multicolumn{4}{|c|}{ exit volume flow rate, $\mathrm{t}^{3} / \mathrm{sec}$} \\
\hline Had & $=$ & \multicolumn{4}{|c|}{ adiabatic head, feet } \\
\hline D & $=$ & \multicolumn{4}{|c|}{ rotor diameter, feet } \\
\hline
\end{tabular}

It will be noted that the specific speed and specific diameter are not dimensionless in the form presented above; however, the parameters can be truly dimensionless when reduced to a form using angular velocity. An example of a typical specific speed, specific diameter performance correlation for full admission axial turbine is shown in Figure B-1. A good approximation of 
the turbine efficiency may be obtained by using an applicable curve such as Figure B-1. As can be seen from Figure B-1, turbine efficiencies greater than $80 \%$ are possible at specific speeds between 40 and about 250 .

Ns-Ds diagrams are used to determine the performance of a turbine for a specific application as follows. The starting point is to calculate the isentropic head drop across the turbine. For the present study employing multiple stage units, this requires the selection of the number of stages and the selection of how the total head available is distributed over the various stages. The volume flow is then determined. For turbines, the volume flow used in the Ns and Ds calculation is taken at the exit of the subject turbine stage. A turbine efficiency is first assumed and then the exhaust specific volume can be determined. This, along with the mass flow, then gives the total flow volume. For the present study, the volume flow can also be adjusted by selecting different numbers of units in parallel. The volume flow for each stage, of course, is also a function of how the head is split up over the various stages.

Now, since it is desired to achieve a certain minimum efficiency, one can determine on the NsDs diagram the lowest value of $N s$ that provides this efficiency. For the present application, the rotational speed is known to be $3600 \mathrm{rpm}$. Therefore, once an exit volume flow rate has been calculated (using an assumed efficiency) and the head drop determined, the specific speed can be calculated. The turbine efficiency is then found from the Ns-Ds diagram. If it is substantially different from the assumed efficiency, the new efficiency is used to recalculate the exit volume flow rate and the process above repeated. The Ds value from the Ns-Ds diagram will determine the turbine rotor diameter. This procedure is much simpler than evaluating the entire detailed equations that govern turtine performance and much time can be saved during a preliminary design phase when selecting or matching turbine components.

More detailed Ns-Ds diagrams also give blade height-to-diameter ratios as a function of specific speed and specific diameter. Thus, the blade height and blade root diameter can be determined. This information can be used to select turbine rotor sizes which best fit a number of turbine applications with the minimum of hardware components and variations.

\section{Thermodynamic Data Base}

At the beginning of this portion of the study, it was discovered that the fluid state point programs used by Barber-Nichols and that used by The Ben Holt Co. produced slightly different results. The basis for The Ben Holt Co. data is the Starling correlation while that used by Barber-Nichols is the National Institute of Standards and Technology (NIST 14).

While the saturation pressure-temperature values vary somewhat between the two data bases, the enthalpy drop for the turbine varies no more than just over $4 \%$. In most cases, the variation is $2 \%$ or less. This certainly is within the accuracy of the study.

As a means of establishing a comparison of the two data bases, the enthalpy difference was determined for similar situations. The data generated by The Ben Holt Co. was used as the basis. Thus, for the sites where subcritical cycles were used, the saturation temperature was determined for the pressure as stipulated in the Ben Holt data. This temperature was then 
rounded up to the next integer value to provide a slight amount of superheat. This pressure and temperature was then used as the turbine inlet condition.

An isentropic expansion to the turbine exit pressure as specified in the Ben Holt data was used to establish the isentropic exit condition. Then an $85 \%$ expansion efficiency was used (the same as used by Ben Holt Co.) to determine the actual turbine exit enthalpy. The enthalpy difference could then be compared with the data from The Ben Holt Co. The actual turbine exit temperature could also be computed and compared.

For the supercritical cases, the pressure and temperature, as specified by the Ben Holt data, was used as the turbine inlet condition. The remainder of the computation was identical to the computations described above.

This data and the results are shown in Table B-1. The enthalpy differences are greater for the commercial isobutane than for the 94-6 mixture. For commercial isobutane, the differences are $2 \%$ to just over $4 \%$. For the mixture, on the other hand, the difference for three of the four cases is much less than $1 \%$. The other case is about $1.5 \%$ different.

These differences are well within the accuracy and assumptions of this study. Therefore, all the Barber-Nichols turbine analysis was completed using the National Institute for Standards and Technology data base. This particular form of the data was a software package named NIST 14.

\section{Baseline Case - Vale}

The Vale resource has a temperature that is about in the middle of the range being considered in this study. Therefore, these conditions were selected for use with a binary plant using commercial grade isobutane to provide a baseline comparison between radial inflow and axial flow turbine designs.

\section{Radial Inflow Turbine}

The radial inflow turbine has performance equivalent to that of an axial flow turbine over a specific speed range of 45 to 110. Above a specific speed of 95 , performance drops off rapidly. For the large multi stage units that are being considered for this project, radial infiow turbines have disadvantages that, in addition to lower maximum allowable specific speed, include very large, expensive housings that are required to accommodate the interstage ducting.

The limitation on the specific speed for radial inflow turbines is very severe and makes it difficult to use multiple stage units with reasonable efficiency. This limitation is a result of the losses associated with this specific hardware configuration. 


\section{Baseline Radial Inflow Turbine}

A baseline radial turbine design was investigated for the Vale resource for a binary plant with a nominal $62,000 \mathrm{~kW}$ gross turbine output (the hydrocarbon flow rate of 7,483,717 pounds per hour, as specified, was used in the computation). To eliminate the need for a gear box, a turbine shaft speed of $3600 \mathrm{rpm}$ is specified. The maximum turbine rotor size is limited to a 36 inch diameter because of the limiting specific speed of about 95 to 110 . For this very preliminary analysis, a number of simplifications have been made which inciude using equal pressure ratio across each stage and assuming negligible pressure drop between each stage.

To satisfy these design parameters, it is necessary to use six units operating in parallel with each unit having four radial flow turbine stages. To minimize the number of turbine housings and generators, a split flow design is used in which the flow enters the middle of the turbine housing and is divided so it flows through two sets of turbine stages. With this design, three housings and three generators will be required. This design has the added advantage of balancing thrust loads on the turbine shaft. Such a possible arrangement is shown in Figure B2.

NASA Lewis Research Center did an experimental performance evaluation of a radial inflow turbine over a range of specific speeds'. This range extended from 72 to 108 . They used a single turbine rotor with four different nozzles designed for $50,75,100$ and 125 percent of design flow.

The maximum efficiency (total-to-static) occurred with the $75 \%$ nozzle and was .87 at a specific speed of 86 . This was four percentage points higher than the .83 obtained for the turbine with the $100 \%$ design flow nozzle at a specific speed of 95.6. At the design blade-jet velocity ratio, the lowest total-to-static efficiency of .77 was obtained at a specific speed of 108.

From these results, it appears that the peak efficiency range of radial inflow turbines occurs at specific speeds ranging from about 80 to 90 . Figure B-3 shows the variation of turbine losses with specific speed at equivalent design speed and pressure ratio. From this figure it is clear that the specific speed of a radial inflow turbine should be limited to the range of about 80 to 90 for efficiencies above $85 \%$.

Figure B-3 is for a specific turbine designed, built and tested by NASA. It illustrates the narrow specific speed range over which radial inflow turbine efficiency can be expected to exceed $80 \%$.

Table B-2 shows some of the key design and performance parameters for a single set (one of six) of radial turbine stages. The efficiencies reported in this table are from more generalized Ns-Ds diagrams and, as a result, are somewhat higher than those reported in the NASA study.

1 "Experimental Performance Evaluation of a Radial In-Flow Turbine Over a Range of Specific Speeds" by Milton G. Kofskey and Charles A. Wasserbaver, NASA TN D-3742, August 26, 1966. 
There are three major disadvantages with a radial turbine for this application. First, the specific speed limitation requires the use of 6 parallel units to limit the maximum stage specific speed to 110. Second, the required shaft diameter may be larger than the eye diameter. Third, radial flow turbines require housings that are large and expensive compared to a comparable capacity axial unit.

With radial inflow turbines, it is especially important not to have the specific speed be too large as the turbine efficiency drop off with increasing specific speed is quite sharp. Therefore, additional units in parallel must be used to decrease the flow rate in each unit to keep the specific speed down. Note that in the above table the specific speed increases with each successive stage. The final stage is the one that must be limited in flow rate. An alternative would be to again split the flow, but this brings in added cost due to more rotors and larger housings.

The smallest eye diameter for the design listed above is 10 inches. For this particular turbine, the required shaft diameter is 7.5 inches from a torque cartying capacity standpoint. Using this shaft diameter and the 10-inch eye (OD) diameter, a blade height of 1.25 inches would be allowed. This is very small. Even more important, from a practical standpoint, the shaft should be sized much larger, probably in the 15-inch diameter range. This is due to critical speed calculations and also due to shaft deflection. If two bearings are used and all (eight) rotors are spaced between them (as shown in Figure B-2), the total bearing span will be over 16 To run reasonable clearances between the rotor and housing minimal shaft deflection can be allowed. Therefore, a larger shaft diameter is required for stiffness. An alternative would be to place more bearings on the shaft between the various rotor stages. This greatly complicates the design and adds significant costs.

The third disadvantage, a large, complicated housing results in high cost. The radial turtine housing must provide interstage passages to duct the flow from the eye of one stage to the nozzle plenum of the next stage. These interstage passages significantly increase the length of the radial turbine assembly compared to an axial turbine. The radial turbine also requires a large diameter nozzle plenum and nozzle ring for each stage. The outside diameter of the nozle plenum for the fourth stage is approximately 72 inches.

\section{Axial Flow Turbine}

An axial turbine design was also investigated for the Vale resource conditions. The major design parameters for the axial turbine are: shaft speed $-3600 \mathrm{rpm}$ maximum stage specific speed -300 , and equal pressure ratio across each stage. The axial turbine has a much higher allowable specific speed (as discussed in Section 2.4). As a result of the larger allowable specific speed, only four parallel units are required for the axial turbine as opposed to six for the radial turbine. The axial turbine will use the same split flow housing design that was described above. Consequently, only two turbine housings and two generators will be required for this resource. 
Table B-3shows some of the key design and performance parameters for a single set (one of four) of axial turbine stages.

A possible arrangement of one set of these axial flow turbines (two turbines back to back) is shown in Figures B-4 and B-5. This is a much more compact and considerably less complex design than the radial inflow turbine shown in Figure B-2.

The axial turbine has a minor performance advantage with stage efficiencies being slightly higher than the radial turtine. The major advantage of the axial turbine is cost. The axial design only requires two turbine-generator units where the radial design requires three. Furthermore, the housing for the radial design is much more complex and has a larger diameter due to plenum arrangement for radial inflow turbines. Furthermore, there is a real conflict between shaft size and the eye diameter for the radial inflow turbine that can only be overcome through the use of a very costly design, namely, multiple bearings. On the basis of these observations, the axial turbine design was selected as the baseline for the other resource conditions studied. Detailed cost information for the axial turbine will be provided in the following sections.

\section{Axial Flow Conceptual Design}

To define an economical multiple stage axial flow turbine for the various sites and working fluids, the goal was set to devise a common design that could be used in all cases. This was accomplished by defining a turbine that could have stages removed or added as necessary depending on the particular site conditions. Additionally, for the high resource temperature sites which have a smaller hydrocarbon flow rate, fewer machines can be used in parallel. 
To identify this generic fits-all turbine, it was first necessary to look at the near optimum turbine configuration for each site. This was done for the isentropic head as described in Section 3.0 for each site along with the hydrocarbon flow rates provided by The Ben Holt Company. Various numbers of units in parallel were assumed for each site along with differing numbers of stages per unit.

Once this multitude of data was compiled, it was possibie to sort through and discover where common rotor sizes were required. Some minor adjustments were made and a final design configuration was chosen. This final design is five stage turbine with the following rotor configuration:

$\begin{array}{lll}\text { Stage } & \text { Rotor } O D_{\text {, in }} & \text { Blade Ht } \\ 1 & 22 & 2.2 \\ 2 & 28 & 2.8 \\ 3 & 36 & 3.6 \\ 4 & 41 & 5.4 \\ 5 & 48 & 7.8\end{array}$

With this design, it is possible to reasonably fit the requirements for each site. This is shown in Table B-4. All of these turbines operate at $3,600 \mathrm{rpm}$ as generators were available in that speed for the power outputs being considered.

\section{Performance}

Once the turbine configuration was known, it was possible to determine the stage efficiencies and then compute the power output. This was done and the result is shown in Table B-5. Note that the power output reported here is not necessarily the optimum value as a number of assumptions have been made. One of the more significant assumptions was to use equal pressure ratios for each stage. That was expedient, but could be fine tuned to produce more power.

In the thermodynamic data section, a discussion of the impact of different thermodynamic data bases was provided. As a means of comparing the present results for the axial flow turbine (Table B-5) to the Ben Holt Co. baseline, single stage, radial inflow turbine, Table B-6 is provided. This table uses the same format as Table B-5 for easy comparison. It will be noted that the axial flow computations generally provide higher power output (for the same hydrocarbon flow rate) even though the enthalpy differences for the Barber-Nichols data base were almost always lower. However, the axial flow computations have the benefit of actual turbine efficiency calculations rather than the assumption of an efficiency of $85 \%$, as used in the Ben Holt Co. computation, and also a better generator efficiency. The gearbox loss for the 
radial inflow turbine is a real difference as the multi stage axial flow machine does not need the speed reducer.

The turbine efficiency difference could be real as the axjal flow turbine can operate at a higher specific speed. This was discussed in detail in the discussion of the baseline case, Vale, Oregon.

\section{Cost}

Given the design discussed above, it was possible to price the various components. Because of the common design, most of the items were used at all sites. The significant difference between the various sites was the use of a single, large generator with two turbines for Surprise Valley and Glass Mountain with isobutane. All other sites used two generators and four turbines. Therefore, the two single generator sites are significantly less expensive on a cost per unit power basis.

In comparing the various sites where two generators were used, there are some minor differences due to the different turbine stages used. These minor differences, along with the minor power output variation, produce nearly level costs per unit power. For the two generator systems, the costs are about $\$ 165$ per kilowatt. The single generator systems are slightly above $\$ 100$ per kilowatt.

The baseline power unit can be priced, less any stages, for the single generator (65 MW) and double generator ( $32 \mathrm{MW}$ ) cases. Pricing it without stages then allows the price addition of the stages required for each site to establish the site dependent price. Note that these costs were generated assuming this was a fully developed turbine. There are no costs included for design engineering or developments costs.

The turbine without stages have the same hardware for both the single or double generator systems and therefore have the same cost. The generators, of course, have difference costs. For the two sizes chosen, the smaller machine costs $\$ 44 / \mathrm{kW}$ while the larger machine costs $\$ 28 / \mathrm{kW}$. This fairly large difference is due to the particular frame sizes that these machines happen to fall into. Other than the generator cost differences, there are only minor differences in the large and small system costs. The cost breakdown for these two sizes of systems are shown in Table B-7.

The cost of the various stages is dependent on the number of blades (both rotor and stator) and the diameter of the stage. The costs for the stages of the particular machines for each site considered here is shown in Table B-8.

The costs in Table B-7 for the baseline unit without stages can be combined with the stage costs given in Table B-8 to obtain the total cost. This is shown in Table B-9 along with the power output and the cost per unit power output. 


\section{Technical Risks}

Designing and fabricating a multiple stage, axial flow turbine as described in this report is well within existing technology. There are no new material problems to overcome nor any extension of knowledge required.

The turbine described here is very similar to present day steam turbines with the exception of somewhat higher pressures than are normally encountered in geothermal service.

The real risk is one of economics. It would require a significant investment to design and construct such a device and to go through the normal development cycle. The company that undertook such an effort would need some form of assurance that there would be a reasonable sized market for such a machine or would need some form of financial assistance from industry/government to undertake this effort. 


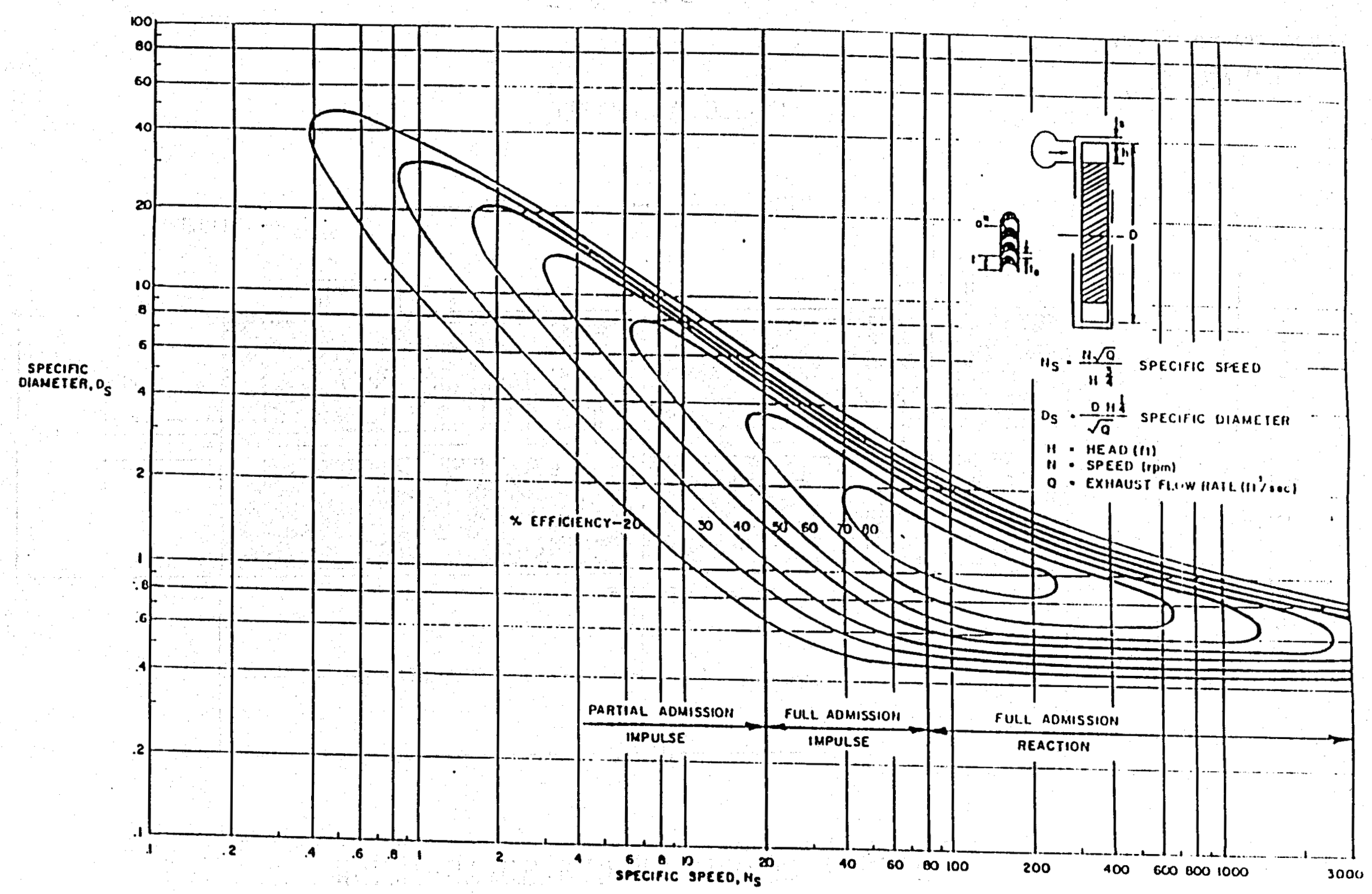

\section{FlGURE $2.1-1$ - OPTIMIZED PERFORMANCE CHART,}

$B-1$ 


\section{MULTI-STAGE RADIAL INFLOW TURBINE}

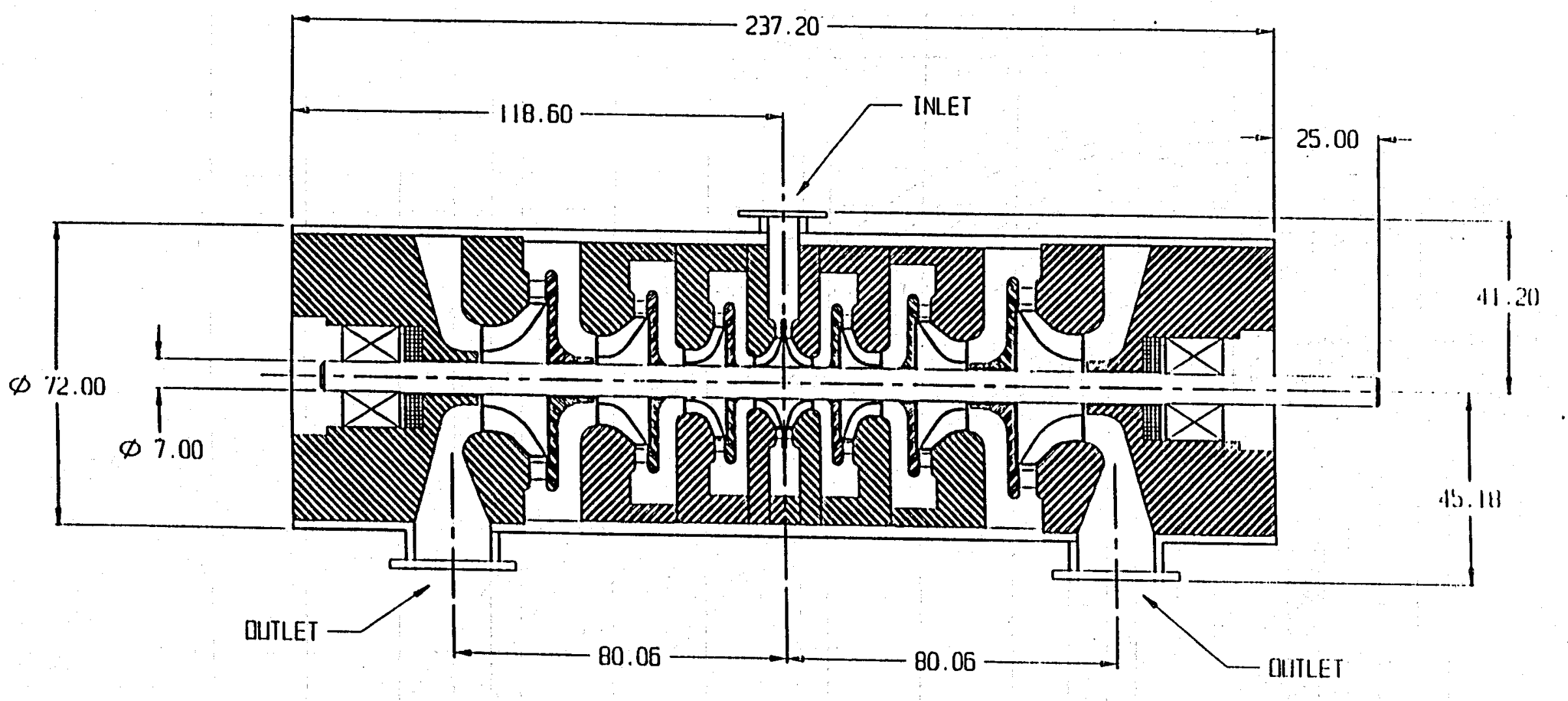

\section{CONCEPTIJAL DESIGN}

FIGURE $4.1-1$
Uarber Nichols

ARVADA, CO. IISA BO002 


$$
\text { FigURE } 4.1-2
$$

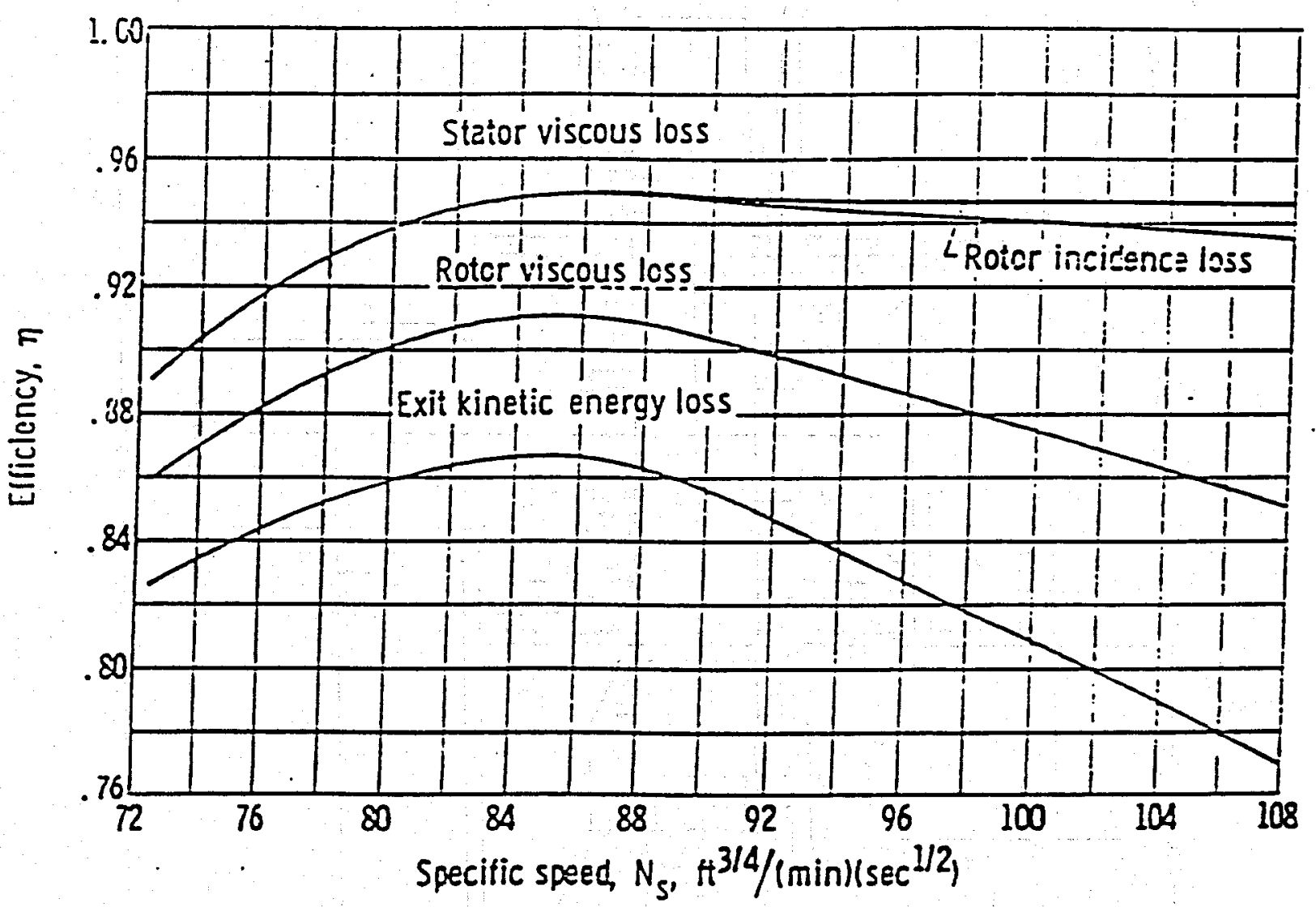

- Variation of turbine losses with specific speed at equivalent design speed and pressure ratio.

$$
\text { Fine bi }
$$




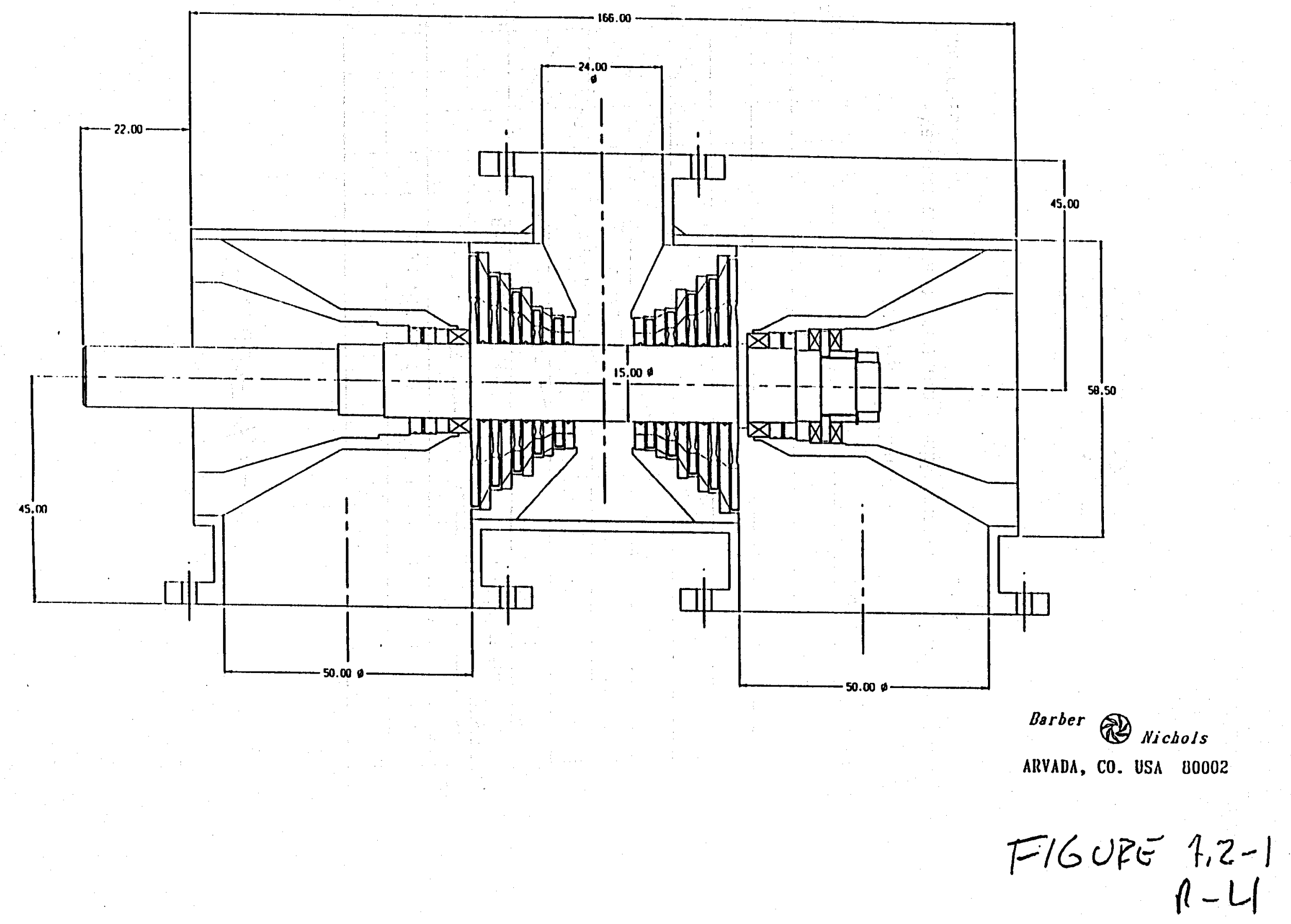




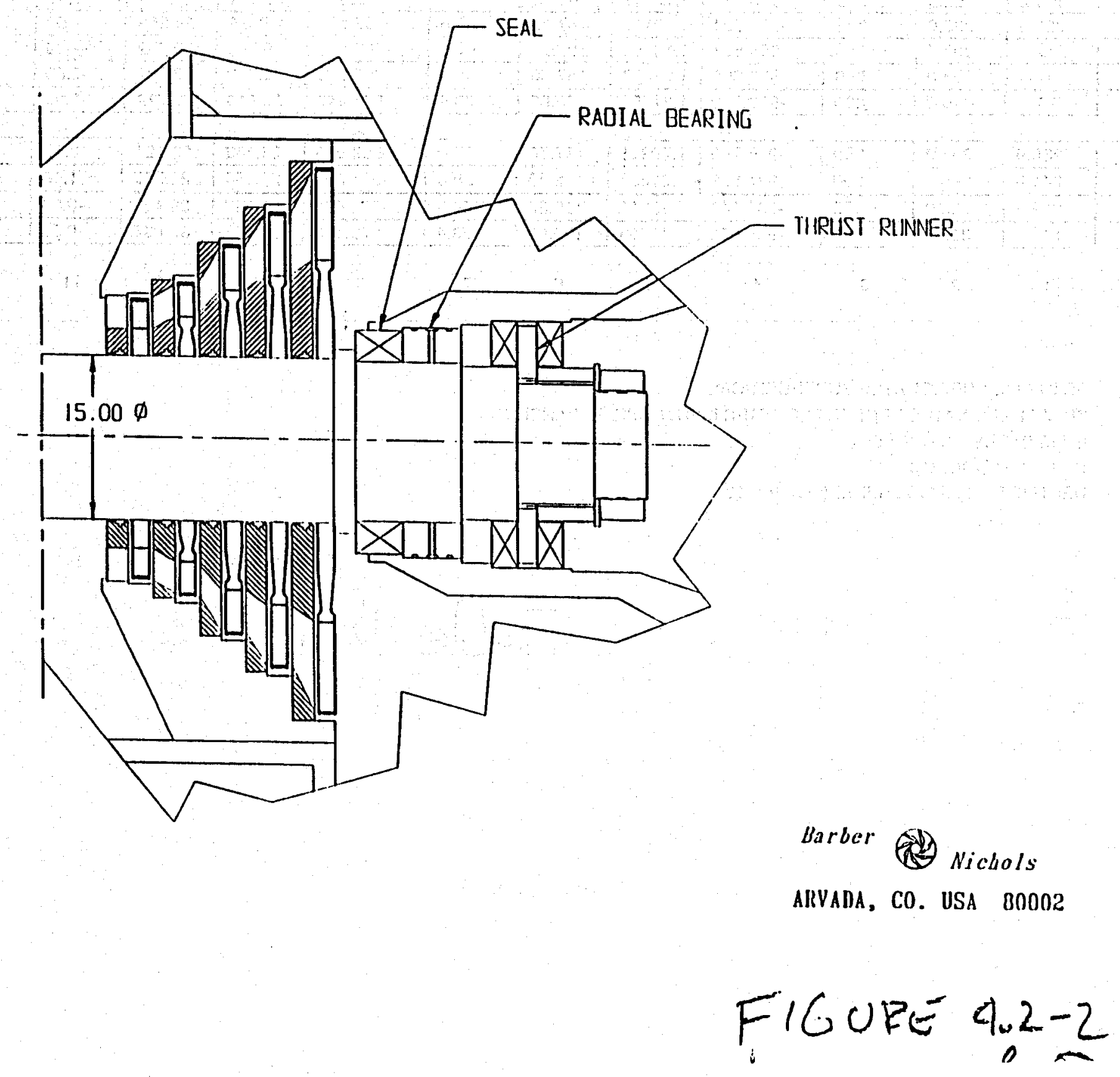


BARBER-NICHOLS

\begin{tabular}{|c|c|c|c|c|c|c|c|c|c|c|c|c|c|c|}
\hline CASE & TDEW & IN & PIN & HIN & SIN & TPRIME & P OUT & H PRIME & BN DEL H & BH DEL H & DIFF & TOUT & $\begin{array}{c}\text { BN DEL T } \\
\text { DEGF }\end{array}$ & $\begin{array}{l}\text { BH DEL T } \\
\text { DEG F }\end{array}$ \\
\hline THS, ICA & $\frac{\text { DEG F }}{191.8}$ & $\frac{\text { DEG F }}{192.0}$ & $\frac{\text { PSIA }}{235}$ & $\frac{\text { BTU/LB }}{-986.725}$ & $\begin{array}{l}\text { BTU/LB-F } \\
1.10902\end{array}$ & $\frac{\text { DEGF }}{101.50}$ & $\begin{array}{r}\text { PSIA } \\
57.2\end{array}$ & $\frac{\text { BTU/LB }}{-.990 .894}$ & $\begin{array}{c}\text { BTURB } \\
20.544\end{array}$ & $\frac{\text { BTU/R日 }}{20.954}$ & $\frac{\%}{-1.08}$ & $\frac{\text { DEG F }}{109.6}$ & $\frac{\text { DEGF }}{82.4}$ & 78.7 \\
\hline $\mathrm{BA}, \mathrm{IC4}$ & 222.4 & 223.0 & 325 & -960.394 & 1.19110 & 107.25 & 60.6 & -988.717 & 24.075 & 24.589 & -2.09 & 116.7 & 100.3 & 101.3 \\
\hline$\overline{v .104}$ & $S C$ & 293.5 & 600 & -954.507 & 1.10864 & 109.70 & 67.0 & .988 .360 & 28.772 & 30.052 & 4.28 & 120.8 & 172.7 & 167.0 \\
\hline SV, ICA & SC & 353.0 & 850 & .920 .868 & 1.22632 & 157.00 & 68.0 & .966 .290 & 38.609 & 39.597 & -2.50 & 171.3 & 181.7 & 179.1 \\
\hline GM. ICA & SC & 340.0 & 800 & .929 .539 & 1.21654 & 146.65 & 68.9 & .971 .443 & 35.618 & 36.674 & -2.88 & 159.9 & 180.1 & 176.8 \\
\hline THS, 94-6 & 230.6 & 231.0 & 250 & .935 .799 & 1.20911 & 137.70 & 55.0 & -963.049 & 23.163 & 23.125 & 0.16 & 146.3 & 84.7 & 81.7 \\
\hline AR. 94-6 & 244.8 & 245.0 & 300 & -931.879 & 1.21037 & 142.40 & 58.3 & .961 .237 & 24.954 & 24.589 & 1.48 & 151.6 & 93.4 & 92.5 \\
\hline V.94.6 & 282.6 & 283.0 & 475 & .931 .143 & 1.20211 & 139.80 & 64.3 & -964.428 & 28.292 & 28.403 & .0 .39 & 146.8 & 136.2 & 134.5 \\
\hline SV, 94-6 & SC & 323.0 & 700 & .935 .686 & 1.19063 & 129.62 & 63.4 & -973.153 & 31.847 & 32.036 & -0.59 & 136.1 & 186.9 & 181.9 \\
\hline
\end{tabular}

NOIES: $\quad$ SC IN COL I DESIGNATES SUPERCRITICAL

PRIME DESIGNATES PROPERTIES AFTER ISENTROPIC EXPANSION

BN IS BAABER-NICHOLS

BH IS BEN HOLT CO

DEL H IS FOR $85 \%$ TUABINE (COL $9 \& 10$ )

$$
\text { Table b-1 }
$$


Table B-2: Radial Flow Turbine Parameters for One of six Parallel Units

\begin{tabular}{|l|l|l|l|l|}
\hline & Stage 1 & Stage 2 & Stage 3 & Stage 4 \\
\hline$T($ in) (F) & 293 & 229 & 184 & 149 \\
\hline $\mathrm{p}$ (in) (psia) & 600 & 347 & 200 & 116 \\
\hline Flow Rate (out) (ft^3/s) & 76 & 155 & 286 & 502 \\
\hline Head (ft-lbf/lbm) & 5170 & 6580 & 7320 & 7600 \\
\hline Ns & 51 & 61 & 77 & 99 \\
\hline Rotor Tip Dia (in) & 21 & 26 & 30 & 36 \\
\hline Eye Diameter & 10 & 15 & 21 & 25 \\
\hline Nozzie Plenum OD (in) & 42 & 52 & 60 & 72 \\
\hline Efficiency & .81 & .82 & .84 & .85 \\
\hline Power (HP) & 2650 & 3420 & 3866 & 4070 \\
\hline
\end{tabular}


Table B-3: Axial Flow Turbine Parametersfor One of Four Parallel Units

\begin{tabular}{|l|l|l|l|l|}
\hline & Stage 1 & Stage 2 & Stage 3 & Stage 4 \\
\hline $\mathrm{T}(\mathrm{in})(\mathrm{F})$ & 293 & 229 & 184 & 149 \\
\hline $\mathrm{p}$ (in) (psia) & 600 & 347 & 200 & 116 \\
\hline Flow Rate (out) (f^^3/s) & 114 & 232 & 428 & 752 \\
\hline Head (ft-lbflbm) & 5170 & 6580 & 7320 & 7590 \\
\hline Ns & 63 & 75 & 94 & 121 \\
\hline Rotor Tip Dia (in) & 23 & 28 & 34 & 40 \\
\hline Efficiency & .83 & .84 & .85 & .86 \\
\hline Power (HP) & 4040 & 5203 & 5870 & 6170 \\
\hline
\end{tabular}


Table B-4: TURBINE STAGING

\begin{tabular}{|c|c|c|c|}
\hline Site/Fluid & No. Parallel Turbines & Number Generators & Turb. Stages Used \\
\hline THS, IC4 & 4 & 2 & $3-4-5$ \\
\hline RR, IC4 & 4 & 2 & $2-3-5$ \\
\hline V, IC4 & 4 & 2 & $1-2-3-4$ \\
\hline SV, IC4 & 2 & 1 & $1-2-3-4-5$ \\
\hline GM, IC4 & 2 & 1 & $1-2-3-4-5$ \\
\hline THS, 94-6 & 4 & 2 & $3-4-5$ \\
\hline RR, 94-6 & 4 & 2 & $3-4-5$ \\
\hline V, 94-6 & 4 & 2 & $2-2-3-4$ \\
\hline SV, 94-6 & 4 & 2 & $2-3-4-5$ \\
\hline
\end{tabular}


Table B-5: BN POWER OUTPUT

\begin{tabular}{|c|c|c|c|c|c|c|}
\hline Site/Fluid & $\begin{array}{l}\text { Hyd Flow Rate, } \\
\mathrm{lb} / \mathrm{hr}\end{array}$ & $\begin{array}{c}\text { Isentrop. } \\
\text { Head, } \\
\text { Btu/lb }\end{array}$ & $\begin{array}{l}\text { Isentrop. } \\
\text { Pwr, } \mathrm{kW}\end{array}$ & $\begin{array}{c}\text { Mech Loss, } \\
\text { kW }\end{array}$ & $\begin{array}{l}\text { Turbine } \\
\text { Effic. }\end{array}$ & $\begin{array}{c}T \\
\text { Por. }\end{array}$ \\
\hline THS/1C4 & $10,536,220$ & 24.169 & 74,612 & 100 & $86.9 \%$ & $64, i$ \\
\hline$R R, I C 4$ & $8,795,528$ & 28.323 & 72,990 & 100 & $86.0 \%$ & $62,6 i$ \\
\hline $\mathrm{V}, 1 \mathrm{C} 4$ & $7,483,717$ & 33.853 & 74,230 & 100 & $85.5 \%$ & $63,:$ \\
\hline SV, $1 C_{4}$ & $5,708,697$ & 45.422 & 75,974 & 50 & $86.2 \%$ & $65, \ldots$ \\
\hline $\mathrm{GM} ; 1 \mathrm{C} 4$ & $6,168,632$ & 41.904 & 75,737 & 50 & $86.5 \%$ & 65,42 \\
\hline THS,94-6 & $9,366,942$ & 27.25 & 74,787 & 100 & $87.0 \%$ & $64, ?$ \\
\hline RR,94-6 & $8,645,803$ & 29.358 & 74,370 & 100 & $86.0 \%$ & $63,8:$ \\
\hline$V, 94-6$ & $7,726,822$ & 33.285 & 75,355 & 100 & $86.0 \%$ & $64 ;$ \\
\hline SV,94-6 & $7,113,635$ & 37.467 & 78,092 & 100 & $86.9 \%$ & $67.7 t$ \\
\hline
\end{tabular}


Table B-6: BH POWER OUTPUT

\begin{tabular}{|l|l|l|l|l|l|l}
\hline Site/Fluid & $\begin{array}{c}\text { Hyd Flow Rate, } \\
\text { lb/hr }\end{array}$ & $\begin{array}{c}\text { Isentrop. } \\
\text { Head, } \\
\text { Btu/b }\end{array}$ & $\begin{array}{c}\text { Isentrop. } \\
\text { Pwr, } \mathrm{kW}\end{array}$ & $\begin{array}{c}\text { Mech Loss, } \\
\mathrm{kW}\end{array}$ & \multicolumn{1}{|c|}{$\begin{array}{c}\text { Turbine } \\
\text { Effic. }\end{array}$} & $\begin{array}{c}\text { Tu } \\
\text { Pow }\end{array}$ \\
\hline THS/1C4 & $10,536,220$ & 24.652 & 76,102 & 0 & $85.0 \%$ & $64,6 \varepsilon$ \\
\hline RR,1C4 & $8,795,528$ & 28.928 & 74,550 & 0 & $85.0 \%$ & $63,3 \epsilon$ \\
\hline V,1C4 & $7,483,717$ & 35.349 & 77,511 & 0 & $85.0 \%$ & $65,8 \varepsilon$ \\
\hline SV,1C4 & $5,708,697$ & 46.585 & 77,919 & 0 & $85.0 \%$ & $66,2:$ \\
\hline GM,1C4 & $6,168,632$ & 43.146 & 77,982 & 0 & $85.0 \%$ & $66,2 \varepsilon$ \\
\hline THS,94-6 & $9,366,942$ & 27.206 & 74,666 & 0 & $85.0 \%$ & $63,4 \epsilon$ \\
\hline RR,94-6 & $8,645,803$ & 29.224 & 74,029 & 0 & $85.0 \%$ & 62,92 \\
\hline V,94-6 & $7,726,822$ & 33.415 & 75,650 & 0 & $85.0 \%$ & $64,3 C$ \\
\hline SV,94-6 & $7,113,635$ & 37.689 & 78,555 & 0 & $85.0 \%$ & $66,7 i$ \\
\hline
\end{tabular}


Table B-7: POWER UNTT COST

\begin{tabular}{|c|c|r|r|}
\hline Line & Cost Element & $32 \mathrm{MW}$ & $65 \mathrm{MW}$ \\
& & Note 1 & Note 1 \\
\hline 1 & Turbine without stages & $\$ 1,435$ & $\$ 1,435$ \\
\hline 2 & Turbine lube system & 150 & 150 \\
\hline 3 & Generator & 1,400 & 1,800 \\
\hline 4 & Generator lube system & 85 & 100 \\
\hline 5 & Couplings & 40 & 60 \\
\hline 6 & Turbine valve & 350 & 350 \\
\hline 7 & Marketing, warranty, profit & 1,000 & 1,500 \\
\hline 8 & Misc. & 300 & 500 \\
\hline & Total & $\$ 4,760$ & $\$ 5,895$ \\
\hline
\end{tabular}

Note 1: Cost is in thousands of dollars 
Table B-8: COST OF STAGES

\begin{tabular}{|c|c|c|r|}
\hline Stage & Pitch dia. inches & Number of blades & \multicolumn{1}{|c|}{$\begin{array}{c}\text { Cost } \\
\text { Note 1 }\end{array}$} \\
\hline 1 & 23 & 90 & $\$ 111,760$ \\
\hline 2 & 25 & 95 & 119,544 \\
\hline 3 & 31 & 100 & 132,640 \\
\hline 4 & 35 & 105 & 143,240 \\
\hline 5 & 41 & 110 & 154,480 \\
\hline Total & & & $\$ 661,664$ \\
\hline
\end{tabular}

Note 1:Cost includes rotor and stator 
TABLE 7.0-3

POWER UNIT COST

\begin{tabular}{|l|l|l|l|l|l|l|l|l|}
\hline \hline Site/Fluid & $\begin{array}{c}\text { Pwr out } \\
\text { per unit, } \\
\mathrm{kW}\end{array}$ & $\begin{array}{c}\text { No. of } \\
\text { unitg } \\
\text { required }\end{array}$ & $\begin{array}{c}\text { Stages } \\
\text { used }\end{array}$ & $\begin{array}{c}\text { Stage } \\
\text { cost }\end{array}$ & $\begin{array}{c}\text { Turb/gen } \\
\text { cost }\end{array}$ & Unit cost & Total cost & \multicolumn{1}{c|}{$\begin{array}{c}\text { Cost per } \\
\text { unit of } \\
\text { pwr }\end{array}$} \\
\hline THS/1C4 & 31,624 & 2 & $3-4-5$ & 430,360 & $4,760,000$ & $5,190,360$ & $10,380,720$ & 164 \\
\hline RR,1C4 & 30,615 & 2 & $2-3-5$ & 406,664 & $4,760,000$ & $5,166,664$ & $10,333,328$ & 169 \\
\hline V,1C4 & 30,954 & 2 & $1-2-3-4$ & 507,184 & $4,760,000$ & $5,267,184$ & $10,534,368$ & 170 \\
\hline SV,1C4 & 64,131 & 1 & $1-2-3-4-5$ & 661,664 & $5,895,000$ & $6,556,664$ & $6,556,664$ & 102 \\
\hline GM,1C4 & 64,153 & 1 & $1-2-3-4-5$ & 661,664 & $5,895,000$ & $6,556,664$ & $6,556,664$ & 102 \\
\hline THS,94-6 & 31,735 & 2 & $3-4-5$ & 430,360 & $4,760,000$ & $5,190,360$ & $10,380,720$ & 164 \\
\hline RR,94-6 & 31,195 & 2 & $3-4-5$ & 430,360 & $4,760,000$ & $5,190,360$ & $10,380,720$ & 166 \\
\hline V,94-6 & 31,609 & 2 & $2-2-3-4$ & 514,968 & $4,760,000$ & $5,274,968$ & $10,549,936$ & 167 \\
\hline SV,94-6 & 33,102 & 2 & $2-3-4-5$ & 549,904 & $4,760,000$ & $5,309,904$ & $10,619,808$ & 160 \\
\hline
\end{tabular}

